\title{
Frontier and Developing Asia
}

The Next Generation of Emerging Markets

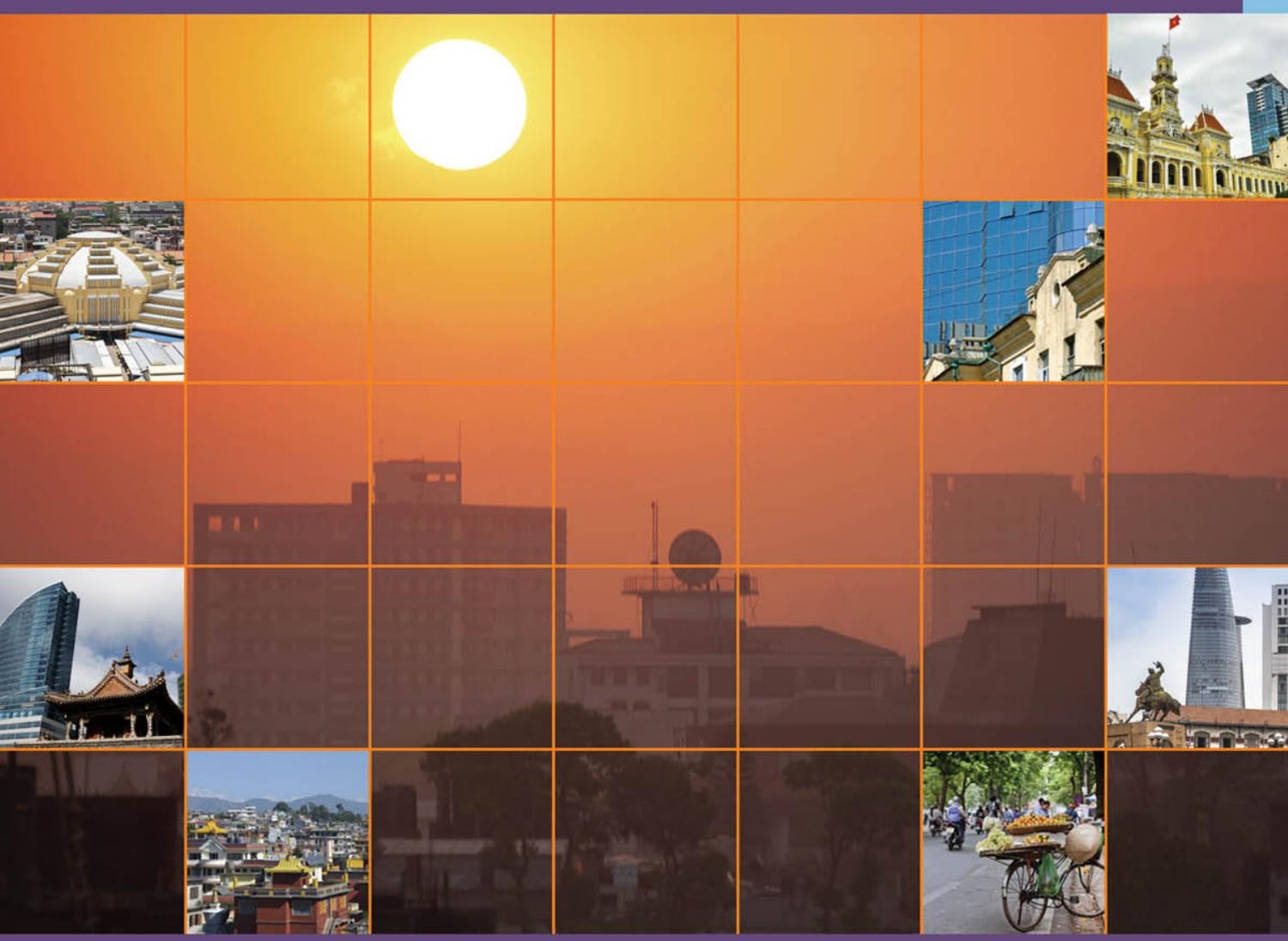

EDITOR

Alfred Schipke 


\section{Frontier and Developing Asia The Next Generation of Emerging Markets}

Alfred Schipke

I N T E R N A T I O N A L M O NETAR Y F U N D 
(C) 2015 International Monetary Fund

Cover design: IMF Multimedia Services Division

\section{Cataloging-in-Publication Data Joint Bank-Fund Library}

Frontier and developing Asia: the next generation of emerging markets / editor: Alfred Schipke. - Washington, D.C. : International Monetary Fund, 2015. p. ; $\mathrm{cm}$.

Includes bibliographical references and index.

ISBN: 978-1-47559-551-2

1. Economic development - Asia. 2. Economic development - Developing countries. I. Schipke, Alfred, 1959- II. International Monetary Fund.

\section{HC415.E44 F76 2015}

Disclaimer: The views expressed in this book are those of the authors and do not necessarily represent the views of the International Monetary Fund, its Executive Board, or management.

Please send orders to:

International Monetary Fund, Publication Services P.O. Box 92780, Washington, DC 20090, U.S.A.

Tel.: (202) 623-7430 Fax: (202) 623-7201

E-mail: publications@imf.org

Internet: www.elibrary.imf.org www.imfbookstore.org 


\section{Contents}

Foreword $\underline{v}$

Preface vii

Contributors $\underline{\mathrm{ix}}$

\section{PART I INTRODUCTION}

$1 \quad$ The Growing Importance of Frontier and Developing Asia ............................ Alfred Schipke

2 Lessons for Frontier Economies from the Recent Experience of Emerging Markets. Itai Agur, Mangal Goswami, Shinichi Nakabayashi, and Sunil Sharma

\section{PART II TRANSFORMING ECONOMIES AND GROWTH}

3 Diversification, Growth, and Volatility $\underline{59}$

Chris Papageorgiou, Nikola Spatafora, and Ke Wang

4 Growth Slowdown: Are Frontier and Developing Asian Countries

Different?

Longmei Zhang and Damien Puy

$5 \quad$ Achieving Inclusive Growth

Ravi Balakrishnan, Chad Steinberg, and Murtaza Syed

PART III I STRENGTHENING POLICY FRAMEWORKS

6 Financial Sector Deepening and Transformation

Era Dabla-Norris, Yasuhisa Ojima, and Marco Arena

7 Addressing Financial Sector Vulnerabilities 165

Todd Schneider, Faisal Ahmed, Rina Bhattacharya, Sergei Dodzin,

Souvik Gupta, Jongsoon Shin, and Xuan Tu

8 Frontier Markets in Asia and Beyond

Nehad Chowdhury, Martin Edmonds, and Chris Walker

9 Monetary Policy Frameworks: An Assessment.

Ashvin Ahuja, Nombulelo Duma, Sarwat Jahan, Yasuhisa Ojima, and Alexandra Peter

Index 
This page intentionally left blank

CInternational Monetary Fund. Not for Redistribution 


\section{Foreword}

For some time now, emerging markets have played an ever-more important role on the global economic stage. Today they account for half of the world's GDP and are a key driver of global growth. At the same time, a new group of countries is getting more and more attention, including from global investors. These are fast-growing low-income countries often referred to as frontier economies.

Within Asia, this group includes countries such as Bangladesh, Cambodia, Mongolia, and Vietnam. They are located in the world's fastest-growing region and benefit from favorable population dynamics. Many of these economies face similar macroeconomic and institutional challenges. Will they become the next generation of emerging markets? What are the policy lessons that might be relevant for other low-income countries?

This book addresses these questions, based on our experience of working with Asia's emerging, frontier, and developing economies over many years. We highlight that continued structural transformation and increased emphasis on inclusive growth will be critical to achieve the full potential of these countries. Also, drawing on the success of today's emerging markets, high growth and rapid structural transformation needs to be complemented by increased investment in "soft" infrastructure to avoid crises down the road. In particular, to realize the strong potential of frontier and developing Asia, upgrading of monetary and fiscal policy frameworks and continued strengthening of financial sector regulation and supervision will be critical.

The IMF is contributing to the progress the frontier economies are making through our ongoing policy dialogue, analytical work, and capacity building. I am confident that this book will contribute to this effort and also raise awareness around the globe of the great potential that Asia's frontier economies have to lift their countries to a new level of widely shared growth and well-being of their citizens.

Christine Lagarde

Managing Director International Monetary Fund 
This page intentionally left blank

CInternational Monetary Fund. Not for Redistribution 


\section{Preface}

Work on frontier economies is in its infancy and publications on the subject are limited. This book aims to fill part of this void. It relies on cross-country analytical work and draws on experience in today's emerging market economies to provide insights and make recommendations relevant for policymakers, think tanks, and academics.

The book would not have been possible without valuable comments, feedback, and contributions from many economists within and outside the IMF. It also benefited from discussions at the 2013 Joint International Monetary FundJapan International Cooperation Agency high-level conference on "Frontier Asia: Economic Transformation and Inclusive Growth" in Bangkok.

The authors would like to thank Ranee Sirihorachai for an excellent job keeping the ball in the air-that is, coordinating the many contributions and comments. Special thanks go to Eric Van Zant for editing the manuscript and to Joanne Johnson of the IMF Communications Department, who did her usual outstanding job coordinating production and publication. 
This page intentionally left blank

CInternational Monetary Fund. Not for Redistribution 


\section{Contributors}

Itai Agur is an economist and joined the IMF-Singapore Regional Training Institute in October 2011. Prior to that he was an economist in the Research Department of the Netherlands central bank, De Nederlandsche Bank, where he worked on issues related to financial stability and macroeconomic forecasting. From 2004 to 2008, Mr. Agur completed his PhD at the European University Institute, Florence, Italy, and has MSc and BSc degrees from the University of Amsterdam. Chapters from his PhD thesis won him the 2007 Young Economist Award of the European Economic Association and the 2008 Arrow Award for Junior Economists from the Berkeley Electronic Press.

Faisal Ahmed is IMF Resident Representative in Cambodia. Previously, Mr. Ahmed worked in the IMF's Monetary and Capital Markets, Strategy, Policy, and Review, and African Departments. Prior to joining the IMF in 2003, he worked as an actuary for a global insurance company for four years and was an external research economist at the Central Bank of the Republic of Turkey and a visiting scholar at the Federal Reserve. Mr. Ahmed has a PhD and an MA in economics from the University of Minnesota and an MFin in finance from Princeton University, and is a Certified Financial Analyst charterholder.

Ashvin Ahuja, Senior Economist in the IMF's Asia and Pacific Department, leads missions to Lao P.D.R. He covered China and Hong Kong SAR from 2010 to 2012. Before joining the IMF in 2010, Mr. Ahuja worked at the Bank of Thailand. He holds a PhD in economics from the University of Minnesota.

Marco Arena is Senior Economist in the Low-Income Countries Unit of the IMF's Strategy, Policy, and Review Department. Mr. Arena holds a master's degree and a PhD in economics from the University of Maryland. Before joining the IMF, he worked as an economist at the World Bank.

Ravi Balakrishnan is Deputy Division Chief of the North American Division of the IMF. His previous positions at the IMF include working on the World Economic Outlook and serving as the IMF's Resident Representative based in Singapore. His policy and research interests cover labor and job dynamics, inequality, inflation dynamics, exchange rate dynamics, and capital flows. His research has been published in the European Economic Review, the Journal of International Money and Finance, and IMF Staff Papers. He has a PhD in economics from the London School of Economics. 
Rina Bhattacharya is Senior Economist in the Bilateral Surveillance Review Division of the IMF's Monetary and Capital Markets Department. Previously, Ms. Bhattacharya worked on low-income and emerging market economies in the IMF's Fiscal Affairs, Middle East and Central Asia, and African Departments. Prior to working at the IMF she was a lecturer at the University of Sussex in Brighton, United Kingdom and subsequently worked at the U.K. Treasury and the Bank of England. While at the IMF she took a two-year leave of absence to work for the Organisation for Economic Co-operation and Development in Paris. Ms. Bhattacharya holds a BA in economics from Cambridge University, a master's degree in development economics from Oxford University, and a $\mathrm{PhD}$ in economics from Yale University.

Nehad Chowdhury joined the IMF in 2011 as an economist in the Monetary and Capital Markets Department. Prior to that he spent eight years at Goldman Sachs, where he was ultimately an Executive Director in London and responsible for advising governments in emerging markets on risks related to their balance sheets and public finances. Mr. Chowdhury has a master's degree in international economics from Harvard University's Kennedy School of Government and a BA in economics from Haverford College.

Era Dabla-Norris is a Deputy Chief in the Strategy Unit of the IMF's Strategy, Policy, and Review Department. She has worked extensively on a range of analytical and policy issues in emerging market and developing countries in Africa, Asia, Latin America, and the Middle East. She has diverse research interests and has published actively in a number of areas, including the determinants of growth in advanced and developing countries, fiscal policy and institutional frameworks, the drivers of official and private flows, monetary policy frameworks, assessing reserve adequacy, and the nexus between public investment efficiency and growth. Her current research focuses on policies, tools, and instruments for managing volatility, financial deepening and inclusion, and structural transformation and productivity-enhancing reforms in advanced and developing countries.

Sergei Dodzin is Senior Economist in the Asia and Pacific Department and a mission chief for Kiribati. He worked on various IMF country teams, including Malaysia, Myanmar, and Singapore and, prior to joining the Asia and Pacific Department, Serbia during the global financial crisis. He also worked on an external assignment at the U.K. Financial Services Authority during 2007-08, where he was involved in supervisory assessment of complex financial institutions and research and supervisory projects. His research interests include international economics, finance, and macro-financial linkages. Mr. Dodzin holds a PhD in economics from Harvard University.

Nombulelo Duma, a national of South Africa, is Senior Economist in the Monetary and Capital Markets Department. Ms. Nombulelo joined the IMF in 2003 and has worked in a number of countries across IMF departments (Asia and 
Pacific, Middle East and Central Asia, Fiscal Affairs). She has worked on various financial stability issues, including through participating in Financial Sector Assessment Programs. Prior to joining the IMF, she worked as an economist at the South African Reserve Bank. She holds graduate degrees in economics from the University of Natal in South Africa and in finance from The George Washington University.

Martin Edmonds is Senior Management Information Officer in the Global Capital Markets Division of the IMF. He worked previously in the Asia Department of the World Bank and at a boutique asset management firm. Mr. Edmonds holds an undergraduate degree from Georgetown University and an MBA from New York University. $\mathrm{He}$ is a Certified Financial Analyst charterholder.

Mangal Goswami has been Deputy Director of the IMF-Singapore Regional Training Institute since June 2010. Before that, he was Senior Economist in the IMF's Monetary and Capital Markets Department, where he participated in a number of Financial Sector Assessment Programs and was a member of the IMF Working Groups on Systemically Important Financial Institutions and Markets and Information Gaps. He was also a country desk economist in the IMF's Middle East and Central Asia Department. Before joining the IMF in November 2000, Mr. Goswami was an economist at ABN AMRO Bank's Global Trading Unit in Singapore and at the Research Department of the Federal Reserve Bank of Kansas City. He has a PhD in economics from Kansas State University and a BA from Coe College in the United States.

Souvik Gupta is an economist in the IMF's Asia and Pacific Department. He is currently working on Bangladesh, the largest financial assistance program by the IMF for a low-income country so far. He has a master's degree in economics from the University of Maryland at College Park and a master of philosophy degree in economics from Delhi University, India. His interests include monetary policy and macro-financial issues. Prior to joining the IMF he worked as an economist in a leading private sector bank in India.

Sarwat Jahan, a national of Bangladesh, is an economist in the Low-Income Countries Strategy Unit of the IMF's Strategy, Policy, and Review Department. Ms. Jahan holds a Master of Social Sciences degree from the University of Dhaka, Bangladesh and $\mathrm{PhD}$ in economics from Cornell University. Before joining the IMF, she worked at the World Bank and taught at Tufts University.

Shinichi Nakabayashi has been at the IMF-Singapore Regional Training Institute since 2011. He was a professor of international finance and public economics at the Graduate School of Public Policy, University of Tokyo, from 2008 to 2011. Mr. Nakabayashi has considerable experience in the design and implementation of public policy, having worked as a senior official at the Japanese 
Ministry of Finance (Director of the Economic Policy Research Office), the Organisation for Economic Co-operation and Development in Paris (First Secretary of Japan's Permanent Delegation), and the IMF (Advisor, Asia and Pacific Department). In July 2010, he coauthored the book The Analysis of the World Economy from the Perspective of Currencies: Dollar, Euro, RMB, and Yen (in Japanese). A sequel, The Economics of G20: International Policy Coordination and the Growth Strategy for Japan (in Japanese), was published in January 2012. Mr. Nakabayashi has an MPhil in economics from Oxford University and a BA from the University of Tokyo.

Yasuhisa Ojima is Senior Economist in the IMF's Asia and Pacific Department and Mission Chief for Tonga. Before joining the IMF, he was a Director in the Credit Risk Analysis division at the Japan International Cooperation Agency and a Resident Representative for the Japan Bank for International Cooperation in Vietnam. He has published several textbooks and articles in the field of international and development economics and taught at Waseda University in Tokyo. Mr. Ojima holds degrees from Yale University and Keio University, both in economics.

Chris Papageorgiou is Deputy Division Chief in the IMF's Strategy, Policy, and Review Department. His work is focused primarily on economic growth and international macroeconomics. He has published extensively, including in the Review of Economics and Statistics, the Journal of Monetary Economics, and the Economic Journal. He is a coeditor of the Journal of Macroeconomics and an editorial board member of the IMF Economic Review and the European Economic Review.

Alexandra Peter is an economist in the Financial Supervision and Regulation Division of the Monetary and Capital Markets Department of the IMF. She worked in the Caribbean II Division of the Western Hemisphere Department prior to her current assignment. She holds a $\mathrm{PhD}$ in economics from the University of Bonn. Her research interests include fiscal and monetary policy, financial regulation, and financial stability.

Damien Puy is an economist (as part of the Economist Program) in the MacroFinance Division of the IMF's Research Department. He also interned in 2012 in the Regional Studies Division of the Asia and Pacific Department. He holds a $\mathrm{PhD}$ from the European Institute in Florence, Italy. His research interests include international finance, macroeconomics, financial economics, and economic history.

Alfred Schipke is Senior Resident Representative for China. Previously, he was Division Chief in the IMF's Asia and Pacific Department, coordinating work on southeast Asia's frontier economies and leading missions to Vietnam. He was Division Chief in the Latin Caribbean Division of the Western Hemisphere 
Department, led regional surveillance missions to the eight members of the Eastern Caribbean Currency Union, negotiated a stand-by arrangement for St. Kitts and Nevis, and was Mission Chief for Saint Lucia. Mr. Schipke was the IMF's Regional Resident Representative for Central America and Mission Chief for El Salvador. He also worked in the IMF European Department and at the Kiel Institute of World Economics. Mr. Schipke teaches international economics at Harvard Kennedy School and has published a number of books and articles. He holds a PhD in economics from Duisburg-Essen University, an MPA from Harvard University, and a BA from Indiana University of Pennsylvania.

Todd Schneider is Deputy Division Chief in the Asia and Pacific Department and mission chief for Sri Lanka and Nepal. He holds a master's degree in international economics and Asian studies from Johns Hopkins University. Prior to joining the IMF, he was Deputy Financial Attaché in the U.S. Embassy in Tokyo and Senior Economist in the U.S. Treasury Department.

Sunil Sharma is Director, IMF-Singapore Regional Training Institute in Singapore. The institute provides training in macroeconomic and financial management and related legal and statistical issues to government officials in the AsiaPacific region. He is also a member of the Advisory Board, Sim Kee Boon Institute (SKBI) for Financial Economics, Singapore Management University, Singapore; the Board of Directors, Mysore Royal Academy (MYRA) School of Business, Mysore, India; and the International Advisory Board, Institute of Global Finance, Australian School of Business, University of New South Wales, Sydney, Australia. Before relocating to Singapore in 2006, Mr. Sharma was the chief of the IMF Institute's Asian Division in Washington. He was also a staff member of the IMF's European and Research Departments and of the Capital Markets Team. Prior to joining the IMF, Mr. Sharma was on the economics faculty at the University of California, Los Angeles. He has a doctoral degree in economics from Cornell University, an MA from the Delhi School of Economics, and a BA from St. Stephen's College, Delhi University.

Jongsoon Shin is an economist in the IMF's Asia and Pacific Department. He joined the IMF in 2011 and participated in various missions, including the Japan Financial Sector Assessment Program and Article IV Consultations in Indonesia and Mongolia. He also contributed to the IMF's flagship reports, including the 2013 Spillover Report, the Global Financial Stability Report (April 2013), and the Regional Economic Outlook: Asia and Pacific (April 2014). Prior to the joining the IMF, he worked for the Korea Financial Services Commission (Banking Division) as well as for the Korea Ministry of Finance and Economy (Macroeconomic Team, and Tax Office). He holds an MBA degree in Finance from the Wharton School of the University of Pennsylvania, and earned his BA degree from the Seoul National University. 
Nikola Spatafora is Lead Research Economist for East Asia and the Pacific at the World Bank. He is currently on leave from the IMF, where he has served in the Research Department, European Department, Fiscal Affairs Department, and IMF Institute. His research interests and publications focus on economic growth, structural transformation, international trade, oil and natural resources, remittances, and foreign direct investment. He has published widely, including in the Journal of International Economics, Journal of Development Economics, IMF World Economic Outlook, and World Bank Global Economic Prospects. His research has also been featured in The Economist, Financial Times, and Wall Street Journal. He holds a PhD in economics from Yale, and a BA (First Class) in politics, philosophy, and economics from Balliol College, Oxford.

Chad Steinberg is Senior Economist in the IMF's Strategy, Policy, and Review Department. He has worked at the IMF since 2002 and was most recently a representative at the IMF's Regional Office for Asia and the Pacific in Tokyo. His research interests include international trade, economic development, and labor markets. He holds a PhD from Harvard University.

Murtaza Syed is Deputy Division Chief in the IMF's Strategy, Policy, and Review Department. He was previously the IMF's Deputy Resident Representative in China, during his tenure writing research papers on China's financial system, investment dependence, trade, demographics, and income distribution. He has also written extensively for Chinese newspapers and magazines. In previous assignments, he covered a range of Asian economies, including Japan, Korea, Hong Kong SAR, and Lao P.D.R. and participated in IMF programs in Dominica and Myanmar. Prior to joining the IMF, Mr. Syed worked at the Human Development Centre in Islamabad and the Institute for Fiscal Studies in London and taught at Oxford. He holds a $\mathrm{PhD}$ in economics from Nuffield College, Oxford University.

Xuan Tu is a research analyst in the IMF's Asia and Pacific Department. She worked on Vietnam and Lao P.D.R. before covering Malaysia, Singapore, and Brunei. Ms. Tu holds a master's degree in International Policy and Development from Georgetown University. Her research interests include economic development, monetary policy, and financial stability.

Chris Walker is Deputy Division Chief in the Global Markets Analysis Division of the IMF's Monetary and Capital Markets Department. Previously, Mr. Walker worked in the IMF's Western Hemisphere Department as Mission Chief for Antigua and Barbuda, and as Desk Officer for Brazil. Before joining the IMF, he was a director in fixed income research for Credit Suisse First Boston in Tokyo. Mr. Walker holds a PhD in economics from the University of WisconsinMadison and a B.A. in philosophy from Swarthmore College. 
Ke Wang is an economist in the Western Hemisphere Department of the IMF. Previously she worked in the Strategy, Policy, and Review Department and the African Department of the IMF, and the East Asia and the Pacific Department of the World Bank. Ms. Wang is a PhD candidate in economics at the American University. Her research has focused on international economics, monetary theory, and economic growth.

Longmei Zhang is an economist in the Regional Study Division of the IMF's Asia and Pacific Department. She joined the IMF in 2010 and worked on Romania and the Philippines before covering regional issues in Asia. She holds a $\mathrm{PhD}$ in economics from Goethe University Frankfurt. Her research interests include economic growth, macroprudential regulation, monetary policy, and business cycles. 
This page intentionally left blank

CInternational Monetary Fund. Not for Redistribution 


\section{Introduction}

(CInternational Monetary Fund. Not for Redistribution 
This page intentionally left blank

CInternational Monetary Fund. Not for Redistribution 


\section{The Growing Importance of Frontier and Developing Asia}

\section{ALFRED SCHIPKE}

Even if a mountain is high, there is always a way to reach the top-and although the way might be full of danger, there is always a way for someone to get through it. (Vietnamese proverb)

Frontier economies, in Asia and beyond, are in the spotlight for their potential to achieve and sustain substantial economic and development gains. Emerging market economies have held center stage for years. But as growth in some slows, and others face what is frequently called the middle-income trap, this new "frontier" group is generating considerable interest among development, investment, and academic communities and policymakers.

\section{WHAT ARE FRONTIER ECONOMIES?}

Although there is no formal definition, frontier economies are increasingly regarded as a separate group of low-income countries that warrants special attention. Compared with other low-income countries, they tend to be dynamic economies that have experienced rapid growth and, in most cases, demonstrated a fair degree of macroeconomic stability over an extended period of time. ${ }^{1}$ Given their strong growth (Figure 1.1), the question arises whether they can become the next generation of emerging market economies and show the way to other lowincome countries striving to improve living standards.

Frontier economies include commodity-rich economies, manufacturing exporters, and dynamic low-income countries spanning the globe from Africa to Asia. In the case of Asia they include countries such as Bangladesh, Cambodia, and Vietnam. In some frontier economies, strong growth is linked with efficiency improvements aided by economic liberalization and trade opening, while the resource-rich ones have benefited from strong external demand and-in the past-high commodity prices. But in a number of these economies, strong growth is also associated with structural transformation and economic diversification.

Global investors are already seeking out some of these countries and more are expected to follow. Some frontier economies-including in Asia-reflect improved macroeconomic fundamentals, which has made them the darlings of

${ }^{1}$ See Zhu (2014) and IMF (2013). 


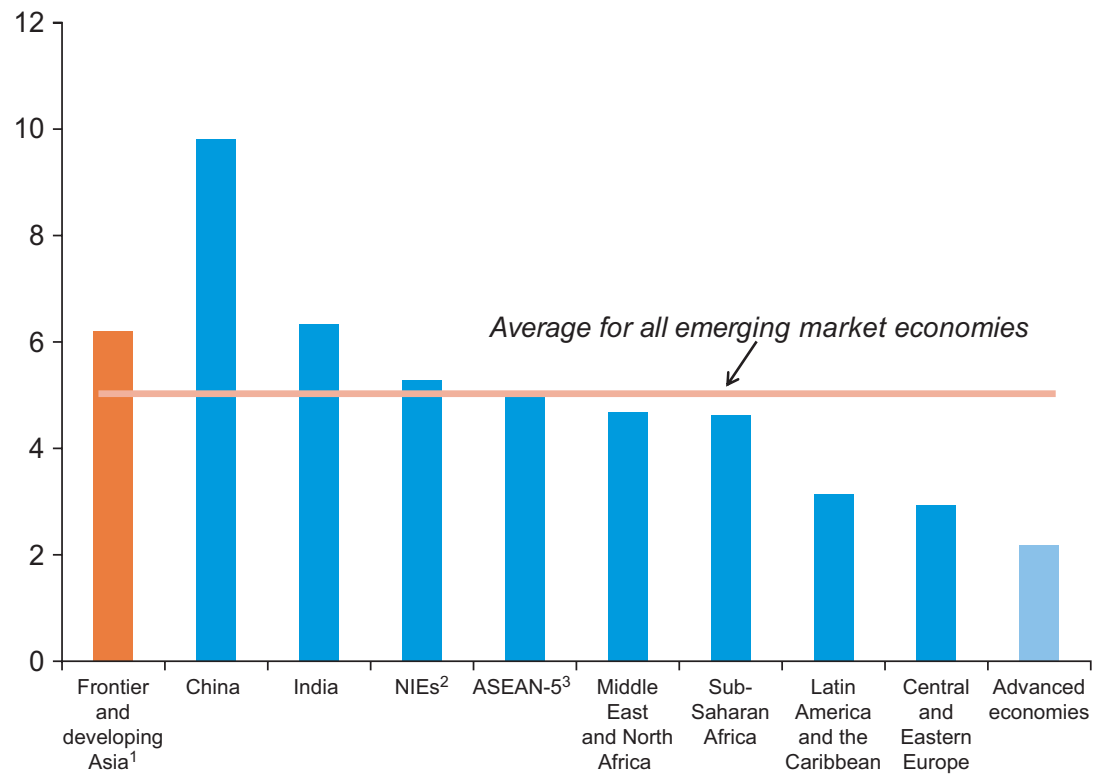

Figure 1.1 Emerging Markets: Real GDP Growth (Annual percent change, 1990-2014)

Source: IMF, World Economic Outlook database.

${ }^{1}$ Frontier and developing Asia includes Bangladesh, Bhutan, Cambodia, Lao P.D.R., Maldives, Mongolia, Myanmar, Nepal, Papua New Guinea, Timor-Leste, Sri Lanka, and Vietnam.

${ }^{2}$ NIEs refers to the Asian newly industrialized economies, Hong Kong, Singapore, Korea, and Taiwan.

${ }^{3}$ ASEAN-5 refers to Indonesia, Malaysia, the Philippines, Thailand, and Vietnam.

the capital markets and allowed them to issue sovereign bonds and attract increased portfolio inflows. Indeed, a subgroup of frontier economies is already part of a new asset class called frontier markets that is distinct from established emerging market economies (Box 1.1). Investor enthusiasm for these frontier markets, however, also reflects a search for yield and unconventional monetary policy in advanced economies that have driven interest rates to historical lows and could present a challenge if the tide were to change.

\section{FRONTIER ASIA: PROSPECTS FOR A BRIGHT FUTURE}

More than 350 million people live in frontier and developing Asia. ${ }^{2}$ Although these countries face many challenges, they are part of the world's fastest growing region, with favorable demographics. In the following chapters, these countries are referred to collectively as frontier Asia. Indeed, with its recent political and

\footnotetext{
${ }^{2}$ Frontier and developing Asia-in the following referred to as frontier Asia-includes Bangladesh, Bhutan, Cambodia, Lao P.D.R, Maldives, Mongolia, Myanmar, Nepal, Papua New Guinea, Sri Lanka, Timor-Leste, and Vietnam.
} 


\section{BOX 1.1 What Are Frontier Markets?}

While the term frontier economy is somewhat loosely defined, the term frontier market reflects a new asset class. Initially, the term was coined by the International Finance Corporation in 1992 to describe developing economies with small but investable financial markets.

A number of financial market indexes now include frontier markets. The Emerging Market Bond Index (EMBI), comprising 54 countries, is the most widely followed index for dollar-denominated debt issued by emerging and frontier market sovereigns. The Next Generation Emerging Market index (NEXGEM) is a subset of the EMBI Global Diversified Index covering exclusively frontier markets. More than 80 percent of this index is rated single-B or lower, with frontier Asia accounting for about 30 percent of the index. The Eurobonds of Mongolia, Sri Lanka, and Vietnam are represented in the NEXGEM (and, by extension, in the EMBI). If Bangladesh were to issue a Eurobond of benchmark size, it would likely be represented in the NEXGEM and investors would view it as a frontier asset.

The Government Bond Index-Emerging Markets is an index of emerging market localcurrency-denominated sovereign bonds, but so far there is no index for local currency frontier bond markets, reflecting the infancy of these markets. Indonesia, Malaysia, the Philippines, and Thailand are represented in the Government Bond Index-Emerging Markets.

Citibank and Bank of America Merrill Lynch also have local currency sovereign bond indices, but none of them has many frontier market names.

economic reforms, another important country, Myanmar, has joined this formidable group.

Despite their heterogeneity, many of these frontier economies face several common macroeconomic, financial, and structural challenges. Some of them have benefited from regional supply chains and the diversification of production facilities across the region. This has allowed companies to combine production in emerging markets such as China and Korea with those in Cambodia, Lao P.D.R. and Vietnam, generating foreign direct investment in these frontier economies. This allows the former to move up the value chain, and benefits the latter.

Not only has frontier Asia as a group grown strongly over a prolonged period, it also performed relatively well throughout the 2007-09 global financial crisis and during the periods of stress in mid-2013 in a number of vulnerable emerging market economies in anticipation of tapering of monetary policy in the United States. Indeed, frontier Asia is expected to remain on a strong growth path.

This is not to say that frontier Asia was unscathed by the financial crisis; many countries in the region still need to rebuild fiscal and external buffers. Furthermore, the more frontier Asia integrates with the global economy, the more it is exposed to shifts in global fortune. Frontier Asia will not only be increasingly vulnerable to developments in advanced economies, but also to slowdowns in the larger emerging market economies to which many frontier Asian countries are linked through trade, foreign direct investment, and remittances. 


\section{HOW TO MAINTAIN HIGH GROWTH AND MAKE IT MORE INCLUSIVE}

Although frontier economies in Asia and beyond have grown strongly and have started to overcome the "poverty trap," they now face the challenge of ensuring that growth remains strong. A critical element of growth is the ability to continuously reallocate resources from less to more productive uses through changing economic structure. This reallocation and diversification helps boost growth and reduce economic volatility. Compared with other frontier economies in the world, some in Asia have diversified quite successfully, especially their exports. Most diversification has occurred by going into completely new products, although in some countries, such as Vietnam, through quality upgrading as well (see Chapter 3).

Globally in low-income countries, a growth reversal often follows the initial take-off, especially in Africa (see Chapter 4). At times, natural disasters or political conflicts cause these reversals, and in others falling commodity prices or weak institutions may set off the decline. Reforms therefore have to focus on continuous structural transformation and diversification, especially against the backdrop of weaker global growth and commodity prices. The reallocation of resources and quality upgrading need appropriate policies; and bottlenecks, including weak public infrastructure, must be addressed.

Strong economic growth in frontier economies has been a key driver of poverty reduction, but the benefits have not been shared equally across all segments of society. Millions remain poor, and inequality has risen dramatically in most frontier economies, except Vietnam. As the experiences of a number of emerging market economies demonstrate, both political and macroeconomic stability require not only strong growth, but also growth that is inclusive (see Chapter 5).

Although no one size fits all, fiscal policies in frontier economies need to focus even more on enhancing social safety nets and increasing spending on health, education, and pensions. Doing this without undermining fiscal sustainability is the main challenge in the medium term. A number of today's emerging market economies provide good examples of how to address inequality through cash transfer programs. India’s recent experiences with a large cash transfer program to issue individual identification cards could provide useful insights, as could Solidario in Chile and Opportunidades in Mexico.

Many segments of society in frontier economies — despite strong credit growth and financial development-still lack access to formal financing, partly reflecting the concentration of credit in a few sectors. Only 30 percent of frontier Asia's population has access to formal financial services, significantly behind the region's established emerging market countries, at about 50 percent (see Chapter 6). Scope is significant for the use of modern financial products, such as cell phone mobile bill payment, and the traditional use of credit cards. Again, frontier Asia trails both emerging market economies and other frontier economies outside the region in both areas. Promoting inclusion by overcoming scale barriers will be 
critical. The use of mobile technology in some countries, such as Smart Money in the Philippines and M-Pesa in Kenya, provides promising examples of what could work in frontier economies as well.

\section{THE NEED TO INVEST IN "SOFT" INFRASTRUCTURE}

High growth has lifted millions out of poverty, but it has also obscured or even worsened weaknesses, making these economies more susceptible to shocks. In contrast to stagnant or slow-growing economies, many Asian frontier economies double in size every 10 years or so, quickly rendering monetary and fiscal policy frameworks obsolete. The same is true for financial sector regulation and supervision. The challenge here is further compounded by rapid structural transformation, which raises the risk that future shocks (including changing global monetary conditions) could reverse progress or even spark a full-blown crisis. As the experiences of today's emerging market economies show, a key challenge for frontier Asia will be to ensure investment in soft infrastructure - that is, constant upgrading of policy frameworks and financial sector regulation and supervision (see Chapter 2).

Frontier Asia's strong growth has gone hand in hand with increased financial sector deepening. In the banking sector, a number of frontier countries, such as Vietnam, are showing credit- and deposit-to-GDP ratios similar to those in emerging market economies, such as Indonesia, Malaysia, and Thailand. Greater banking sector efficiency, reflected in falling interest margins, has also accompanied financial sector deepening in such countries.

Globally, financial sector deepening is associated with economic growth and poverty reduction and helps reduce output volatility. And more developed financial systems are essential for improving the effectiveness of macroeconomic policies. That said, such deepening can also lead to a buildup of significant risks and misallocation of resources that can undermine stability and growth potential. Taking into account structural characteristics such as economic development, demographics, population density, and other fundamentals, a number of frontier Asian economies already have private-credit-to-GDP ratios exceeding expected values. Recent financial system stresses in some of the countries have highlighted the risk of overly rapid financial sector development. Because regulatory and supervisory reform in frontier Asia has lagged other regions and often remains relatively weak, the risks of a buildup of vulnerabilities and a misallocation of resources are significant (see Chapter 7).

Furthermore, compared with emerging market economies, frontier Asia's financial systems are undiversified and their structure continues to differ significantly. Frontier Asian financial systems remain largely bank based, and in a number of countries, state-owned banks still dominate. The strong presence of large state-owned enterprises in some countries partly explains the difficulties that medium and small firms have in accessing credit.

At the same time, strong links between state-owned banks and enterprises in a number of frontier Asian economies has resulted in lending that is not purely 
based on commercial considerations. This results in a high number of nonperforming loans and can, of course, undermine financial system stability. To identify these weaknesses and embark on financial sector reforms, Bangladesh, Cambodia, Mongolia, Papua New Guinea, Sri Lanka, and Vietnam have already undertaken IMF Financial Sector Assessment Programs.

As with financial sector supervision and regulation, monetary policy frameworks in many frontier economies have also not kept up with economic development, possibly undermining the ability to deal with shocks. When economies take off, intermediate exchange rate regimes can be appropriate, given evidence that they deliver price stability without sacrificing growth or causing growth volatility. But as frontier Asian economies develop their financial sectors and become more integrated into global capital markets, their monetary policy frameworks will need to be updated and strengthened. And for now, in frontier Asia's more rudimentary frameworks, the first step is to introduce greater operational autonomy for central banks and to widen exchange rate bands. Once the region progresses from monetary targeting to forward-looking policy that makes use of interest rates, more emphasis will be needed to deal with shocks. This will in turn allow countries to pursue more active monetary policy to manage aggregate demand (see Chapter 9).

\section{A NEW ASSET CLASS: FRONTIER MARKETS}

As noted, a couple of frontier Asian economies have been able to tap global capital markets with sovereign bonds. Others may follow soon. These frontier markets make up a new asset class and are included in global investment indices (see Chapter 8). Compared with established emerging market economies, however, they are considered economically and politically more challenging. The size of their outstanding debt is smaller and they are less liquid, which in turn is reflected in credit ratings several notches below investment grade. Still, nonresident investors have shown interest in a number of domestic bond and equity markets in frontier economies. Although this allows these countries to access foreign savings, improve the allocation of financial resources, and create conditions for better risk sharing, it could make them more vulnerable to sudden stops in capital inflows or even capital outflows.

Investors' search for yield has helped some of the frontier economies access capital markets. The question therefore arises: what will happen with changes in expectations about the unwinding of unconventional monetary policy in the United States or if investors suddenly become more risk averse? Given the small markets and huge information costs, investors are not likely to distinguish among the different frontier markets. They could treat them as one asset class, raising the risk of contagion and implying little discrimination across countries, irrespective of fundamentals. At the same time, given the lack of liquidity, the investor base of frontier markets consists exclusively of more long-term-oriented and realmoney investors. This compares with investors in emerging markets, where global bond funds are limited to investment-grade investment. 
During turmoil in vulnerable emerging market economies around mid-2013, triggered by mere talk of tapering of the Federal Reserve's bond purchases, frontier markets were largely unscathed and less volatile. This reflected not only their improved economic fundamentals, but also that, given the less liquid and smaller nature of frontier markets, they attracted more dedicated investors.

However, as the exposure of frontier markets to the global system increases, so does the risk of a sudden halt in capital inflows or of capital outflows. The appropriate policy response will depend on each country's circumstances and exchange rate regime. But continued pursuit of sound macroeconomic policies and, in some cases, further strengthening fiscal and external policy buffers will be paramount. The experiences of today's emerging market economies suggest that regulation and supervision must keep up with financial sector development to minimize the risk of financial and macroeconomic instability. Many frontier economies need significant upgrading in their supervisory tools and financial regulation, including provision for sufficient resources. Frontier economies also need to address information gaps, such as those in credit registries.

\section{A CHALLENGING PATH}

The prospects for many frontier Asian economies to become the next generation of emerging market economies and to join the group of middle-income countries are very good. However, getting there will not be without challenges, and countries will have to avoid complacency and accelerate reforms to unleash their full growth potential, minimize volatility and avoid crises, and move up the value chain, which will be necessary to sustain high growth.

In particular, reforms have to focus on fostering structural transformation and diversification to help sustain high growth. Scope is also significant to make growth more inclusive and to improve safety nets. In the short term, this would require such things as strengthening conditional cash transfer programs and improving access to financing. At the same time, reforms have to focus more on upgrading and strengthening policy frameworks, which have not always kept up with robust growth.

Managing high economic growth is challenging. As well as capacity constraints, the benefits from investments in soft infrastructure are not as tangible as investments in physical infrastructure, are less well understood by the public, and are often deemed less urgent. Upgrading policy frameworks requires more effort to educate the public about the costs of neglect and will require political capital to achieve progress. Failure to upgrade policy frameworks could undo many achievements the next time a domestic or external shock hits. As frontier Asia becomes more globally integrated, policymakers will also have to focus increasingly on how to manage risks and deal with macro challenges and with increased vulnerabilities. Here, yesterday's frontier and today's emerging market economies offer lessons. These include the importance of sequencing reforms, the risk of excess growth and bubbles, and the need for the financial sector regulatory and supervisory capacity to keep up with financial sector deepening and economic growth. 
With the right policies, however, frontier economies should be able to realize their full potential and become the next generation of emerging market economies.

\section{REFERENCES}

International Monetary Fund. 2013. World Economic Outlook, Chapter 4 (Washington: International Monetary Fund).

Zhu, Min. 2014. "The New Frontier: Economies on the Rise." IMF Direct, May 19, http:// blog-imfdirect.imf.org/2014/05/19/the-new-frontier-economies-on-the-rise. 


\title{
Lessons for Frontier Economies from the Recent Experience of Emerging Markets
}

\author{
Itai Agur, Mangal Goswami, Shinichi NakabayashI, \\ AND SUNIL SHARMA
}

Frontier economies have grown rapidly since the turn of the century. While GDP growth rates have varied considerably among the countries in this group, their average growth and inflation rates have been generally higher compared with emerging market economies (Figure 2.1). ${ }^{1}$ But whether the current trajectories of frontier economies will eventually lead to emerging markets and then middle-income status depends on tackling a number of structural deficiencies and containing the buildup of macroeconomic and financial risks in the transition.

Frontier economies face fundamental challenges in their economic and institutional development. They have to tackle deficiencies in governance, the rule of law, basic infrastructure, and the skills of the workforce to accelerate and maintain growth in incomes per capita. ${ }^{2}$ A necessary, but not sufficient, condition for success is having reasonably effective macroeconomic frameworks for conducting policies to facilitate and support growth and institutional change.

They will need to deal with these hurdles to development in the context of an international financial architecture that seems to be spawning more frequent

\footnotetext{
${ }^{1}$ This comparison uses the Morgan Stanley Capital International (MSCI) categories as of March 2014. The MSCI-Emerging Market group consists of Brazil, Chile, China, Colombia, Czech Republic, Egypt, Greece, Hungary, India, Indonesia, Korea, Malaysia, Mexico, Peru, Philippines, Poland, Russia, South Africa, Taiwan Province of China, Thailand, and Turkey. The MSCI frontier markets cluster contains Argentina, Bahrain, Bangladesh, Bulgaria, Croatia, Estonia, Jordan, Kazakhstan, Kenya, Kuwait, Lebanon, Lithuania, Mauritius, Morocco, Nigeria, Oman, Pakistan, Qatar, Romania, Serbia, Slovenia, Sri Lanka, Tunisia, Ukraine, United Arab Emirates, and Vietnam. A broader categorization of frontier economies would include the following Asian countries: Bhutan, Cambodia, Lao P.D.R., Maldives, Mongolia, Myanmar, Nepal, Papua New Guinea, and Timor-Leste. ${ }^{2}$ See, for example, Acemoglu, Johnson, and Robinson (2005); Gill and Kharas (2007); Acemoglu and Robinson (2012); Rodrik (2013); Im and Rosenblatt (2013); and Nunn and Trefler (2014). In the context of India, see the discussion in Bhagwati and Panagariya (2013) on what they call Track I and Track II reforms. Basu (2011) shows that a market system needs cooperation, trust, and appropriate norms to deliver growth that is reasonably efficient and fair. Fukuyama (2004) discusses the causes of "state weakness" in developing economies and the difficulties faced in creating new government institutions and strengthening existing ones.
} 

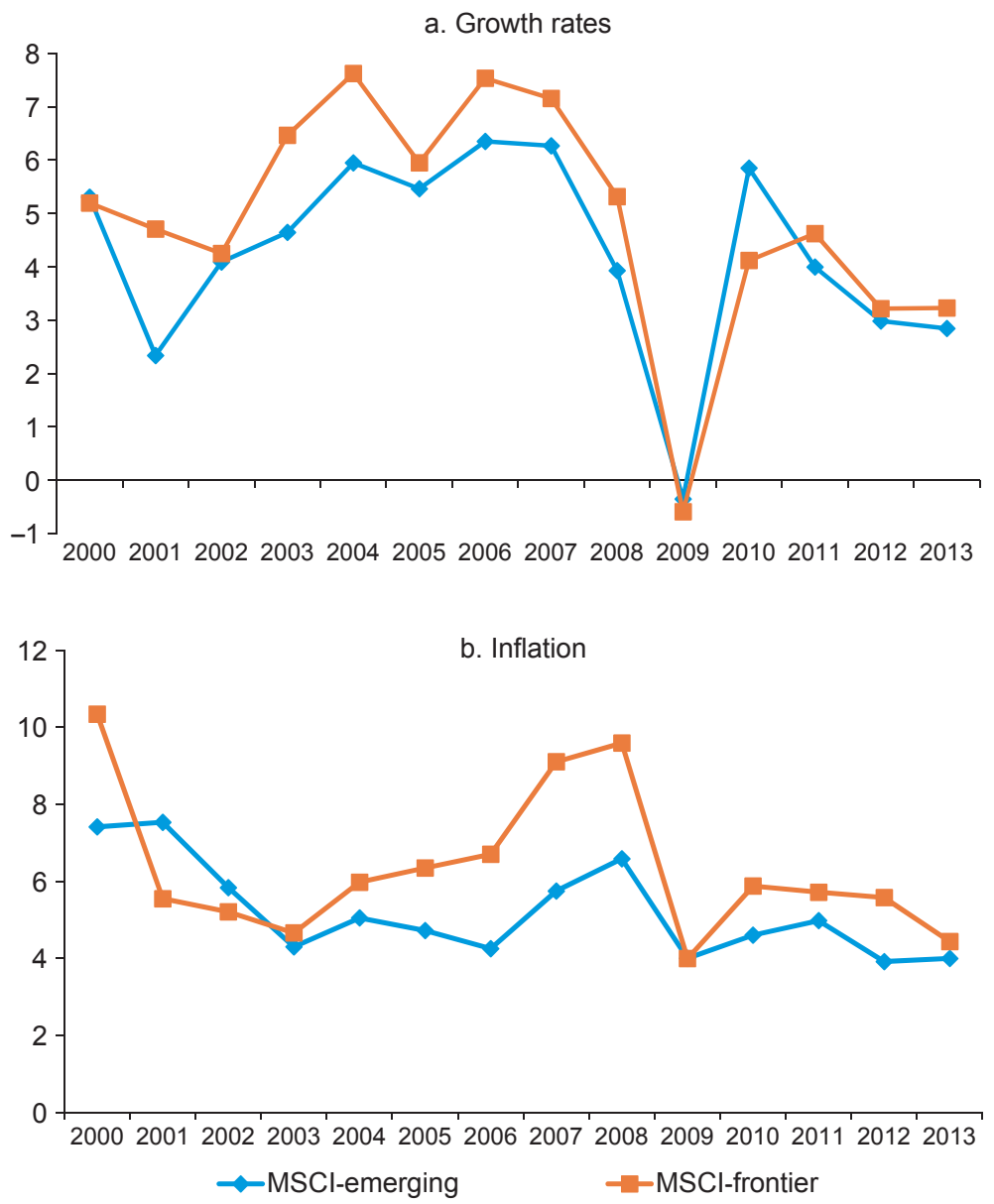

Figure 2.1 Emerging and Frontier Markets: Average Growth and Inflation Rates

Source: IMF, World Economic Outlook, October 2013.

Note: The charts use the Morgan Stanley Capital International (MSCI) categorization of emerging and frontier markets.

crises, with contagion spreading to all parts of the globe. Achieving low inflation, sturdy exchange rates, financial stability, and sustained growth is a difficult balancing act under the best of circumstances. In a world of volatile capital flows and cross-border spillover from large regional and global economies, charting a steady growth path will be a difficult act for frontier markets unless monetary, financial, and fiscal policies are mutually consistent, sufficiently flexible, and generally pulling in the same direction. It will be important for frontier markets to avoid the "boom-bust" cycles that have derailed and set back the development and convergence process for emerging market economies in the past.

CInternational Monetary Fund. Not for Redistribution 
In this chapter, we examine the recent experience of emerging market economies to draw some macroeconomic and financial lessons for the frontier economies.

\section{MONETARY AND EXCHANGE RATE POLICIES}

The international financial system has changed profoundly in the past few decades, posing new challenges for emerging market economies in the maintenance of internal and external balances. During the Bretton Woods era, severe constraints on capital mobility coupled with a globally coordinated exchange rate system shielded developing economies against sudden losses in their international reserves. While external imbalances were frequent, limited capital mobility afforded countries long adjustment periods, and devaluations and expenditure restraint were expected to provide relief from trade deficits. Over the past few decades the acceleration of international financial integration and the experiences of emerging market capital account crises have changed the nature of macroeconomic management in emerging market economies. In particular, with flexible exchange rates, a strong nominal anchor was needed to stabilize inflation expectations and promote price stability, with important implications for central banking and for the monetary policy frameworks the emerging market economies adopted. ${ }^{3}$

\section{Evolving Exchange Rate Regimes}

The "macroeconomic policy trilemma" provides a useful framework for analyzing emerging market monetary policy responses as international financial integration accelerated in the 1990s. In the context of increasing capital mobility, it highlights the trade-off between the degree of exchange rate stability and the extent to which governments can act to stabilize economic activity and domestic price levels (see Figure 2.2). Simply stated, with an open capital account and a fixed exchange rate, any deviation of a country's interest rate from the globally prevailing interest rate would lead to arbitrage and trigger capital inflows that would force a country to either abandon its peg or readjust its interest rate. Reality, however, is more complicated as many countries operate somewhere in the middle rather than at the vertices of the trilemma. ${ }^{4}$ Emerging market economies grapple with managing exchange rate levels and variability, the degree of monetary policy independence, and the process of financial liberalization. ${ }^{5}$

Emerging market experience during and in the aftermath of the global financial crisis has called into question whether the trilemma framework still appropriately captures the policy trade-offs faced. Extensive monetary accommodation

\footnotetext{
${ }^{3}$ For recent discussions of emerging market monetary policy frameworks see Hammond, Kanbur, and Prasad (2009); Filardo and Genberg (2010); and Filardo (2012).

${ }^{4}$ For example, see Hutchison, Sengupta, and Singh (2010).

${ }^{5}$ For a perspective from Asia-Pacific policymakers on the conduct of monetary and financial policies in a world of increasing cross-border flows see Grenville (2008); Mohan and Kapur (2009); Nijathaworn and Disyatat (2009); Singh (2009, 2011); Mohan (2012); Gokarn (2013); Kim (2013); Zeti (2013); Rajan (2013, 2014); and Menon (2014).
} 


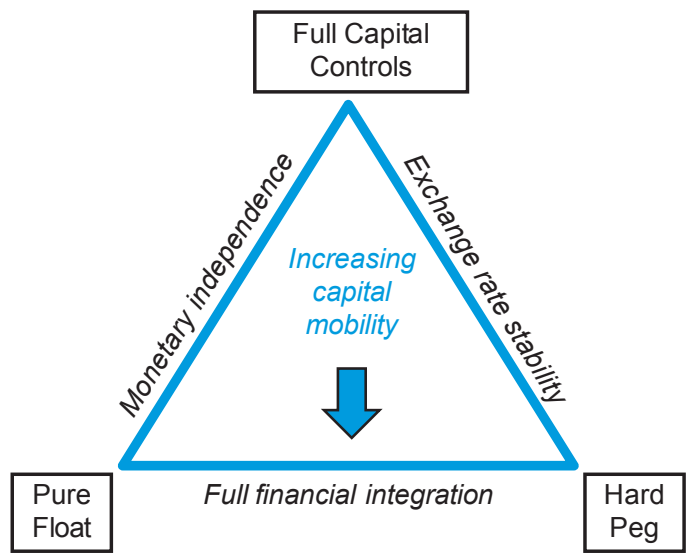

Figure 2.2 The Trilemma Framework

Source: Authors.

by advanced economies, in the form of protracted low interest rates and quantitative easing policies, led to a search for yield among global investors. Capital flows in the form of portfolio flows and cross-border banking lowered the yield curves of many emerging market economies. This, in turn, greatly influenced credit creation and business cycles in those countries. It seemed that irrespective of a country's exchange rate regime, monetary autonomy dwindled for emerging market economies with relatively open capital accounts. This has led Rey (2013) to argue that the policy trilemma has essentially become a policy dilemma, whereby the only choice is between capital account liberalization and monetary independence. Others take the view that the trilemma remains valid, but that the trade-offs have become starker, and the burden placed on monetary policy has no doubt become heavier in the aftermath of the global financial crisis (Obstfeld 2014). Large capital flows and financial stability concerns have complicated the conduct of monetary policy, but do not negate its independence per se. In any case, the trilemma provides a useful framework to discuss the historical evolution of emerging market policy regimes and the implications for frontier economies, which are still in the initial stages of international financial integration.

Even after the demise of Bretton Woods, exchange rate stability has remained important. Developing economies prefer to place bounds on exchange rate variability, including through various forms of capital account management measures. Exchange rate regimes have ranged from so-called managed floats, in which policymakers decide on an ad hoc basis when to intervene in markets, to fully fixed ones, in which policymakers commit to maintaining their country's exchange rate at a given value against another currency or a basket of currencies. Freely floating exchange rates are a rarity among developing economies, which is sometimes referred to as a "fear of floating" (Calvo and Reinhart 2002). Figure 2.3 depicts the 


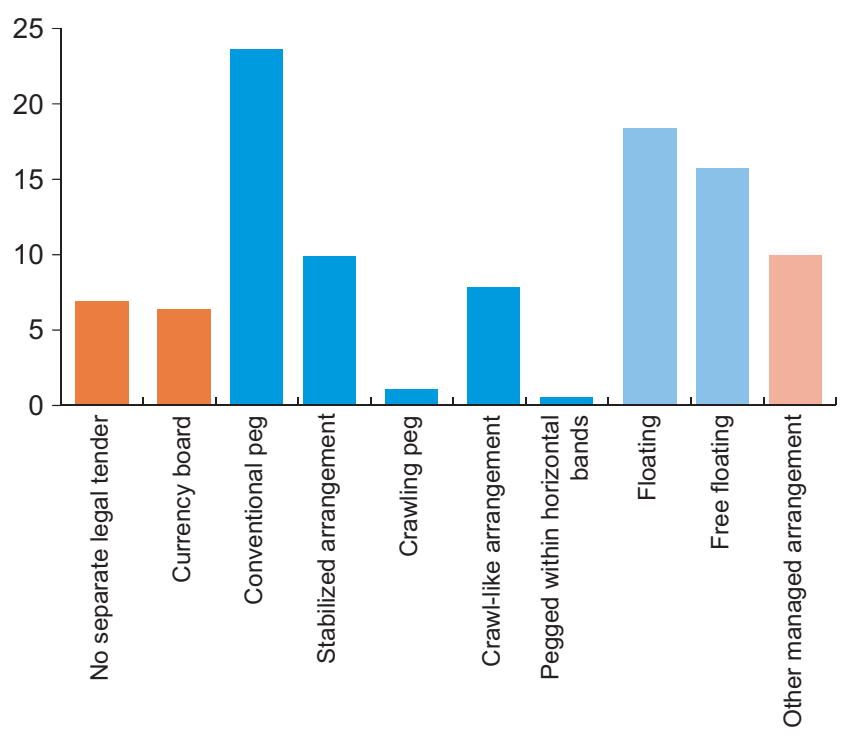

Figure 2.3 Exchange Rate Arrangements in 2013 (Percent of IMF member countries) Source: IMF, Annual Report on Exchange Arrangements and Exchange Restrictions (2013).

spectrum of exchange rate regimes based on both de jure and de facto classifications. It shows a pronounced shift away from relatively fixed exchange rate arrangements to intermediate regimes.

The fear of floating in emerging market economies results because a volatile currency is highly disruptive to local consumers, firms, financial intermediaries, and governments. In (small) open economies a large fraction of the consumption basket usually consists of imported goods, especially fuel and food, and hence movements in the exchange rate pass through quickly to domestic prices, affecting consumer purchasing power and welfare. Moreover, firms, financial intermediaries, and governments frequently face domestic borrowing constraints and have to rely on foreign-currency-denominated borrowing, which directly connects effective indebtedness to the exchange rate, as country examples discussed later in this chapter highlight.

The choice of an exchange rate regime hinges on economic structure (Fischer 2001). For countries with rigid labor and product markets, a more flexible exchange rate has the advantage of allowing for easier adjustment in the face of competition. On the other hand, small economies that rely heavily on trade, especially those that have one dominant trading partner, see significant benefits in pegging their exchange rate to the currency of a trading partner.

Even if a central bank set monetary policy independently of external influences, it may not be truly autonomous. In particular, many countries have experienced bouts of high inflation that had their roots in what is termed "fiscal dominance." Fiscal dominance occurs when monetary policy is subjugated to 
fiscal policy since the "printing press" is required to meet budgetary needs in the face of a small tax base or collections (see the Fiscal Policies section). Using the exchange rate as a nominal anchor can be a useful disciplining device, but its viability depends ultimately on having supportive fiscal and structural policies. Calvo and Mishkin (2003) caution that exchange rate regimes cannot effectively substitute for institutional development. A regime choice can therefore at best be a signal of a government's commitment to suitable policies and structural reform, and it is of particular relevance to frontier markets embarking on creating and improving institutions and policies.

\section{External Imbalances, Learning to Float, and Building Buffers}

Exchange rate regimes with hard pegs have often been successful at containing inflation, but without supporting policies they can lead to declining competitiveness and external imbalances. ${ }^{6}$ Even in successful disinflation episodes, it can take several years for a country's inflation rate to converge to that of the country it is pegged to, and hence it may see a real exchange rate appreciation in the transition. Argentina's experience with a currency board provides an example (Box 2.1).

Prior to the Asian crisis, most Asian emerging market economies had fixed exchange rates that closely shadowed the U.S. dollar. When the U.S. dollar appreciated against other currencies, such as the Japanese yen, the Asian emerging market currencies were towed along, eroding external competitiveness and widening already large current account deficits. One way to mitigate this link of a country's competitiveness to another country's exchange rate is by pegging to a basket of currencies that better reflects a country's trade profile. But the use of a currency basket provides less clarity than a peg to a single currency.

The Asian financial crisis resulted from a combination of external imbalances from misaligned exchange rates and balance sheet mismatches (currency and maturity) brought about by increasing international financial integration. Higher Asian interest rates relative to the United States led to a large-scale carry trade, and for a while commitments to maintaining U.S. dollar pegs were not questioned. The financial and corporate sectors of Asian emerging market economies built up foreign-exchange-denominated external debts, usually of short maturity. When the capital flows reversed, international reserves proved inadequate, and debt burdens soared as currencies depreciated (IMF 1998; Eichengreen and Hausmann 1999; Frankel 2005). Currency depreciation to correct current account deficits and stem the loss of foreign exchange reserves became a double-edged sword because of balance sheet mismatches. Although prior to the Asian crisis the fiscal positions of Asian emerging market economies had generally seemed healthy, the bailouts of the private sectors created sizable fiscal burdens and contingent liabilities for the governments. This suggests that frontier markets should probably build up appropriate fiscal and foreign exchange reserve buffers

\footnotetext{
${ }^{6}$ For instance, see Obstfeld and Rogoff (1995); Frankel (2003); and Edwards (2011).
} 


\section{BOX 2.1 Argentina's Currency Board}

In 1991, Argentina's congress passed a law mandating that the Argentine peso be convertible on a one-to-one basis against the U.S. dollar, and that the central bank's sole monetary policy target be to maintain this peg by providing cover for the entire monetary base with U.S. dollar reserves. At the time Argentina implemented this currency board arrangement, it was a relatively closed economy, with exports and imports each constituting little over 10 percent of GDP. Hence, limiting the impact of exchange rate volatility on the real economy was not a key consideration in the choice for the exchange rate regime. Rather, the aim was to provide a credible anchor for monetary policy to curtail the hyperinflationary tendencies that had plagued the Argentine economy. And, in that respect, the currency board arrangement proved very successful: inflation that had been running at 2,314 percent in 1990 and 172 percent in 1991 fell to 25 percent in 1992 and reached single digits in 1994 .

By 1995, Argentina's inflation had converged with that of the United States. But unfortunately this achievement in price stability exacted a toll on the country's external competitiveness, because along the convergence path, inflation in Argentina had remained considerably higher than that in the United States, and it experienced a sizable real exchange rate appreciation of about 25 percent. Consequently, Argentina's export growth remained subdued, imports surged, and the current account deficit widened to over 4 percent of GDP.

Large capital inflows were required to finance the current account deficit. Foreign lenders were quite eager to provide funds based on Argentina's perceived gains in monetary credibility, GDP growth powered by rising private consumption and investment, and persistently loose fiscal policy. The government and private sector borrowed at relatively low interest rates as foreign investors demanded only a small country risk premium. However, the external funding came in a form that has often proved to be a prelude to vulnerabilities in the developing world-namely foreign-exchange-denominated debt. Since the currency board implied that pesos and dollars were virtually identical, and currency mismatches no longer seemed to matter, both borrowers and lenders perceived little risk in the issuance of dollar-denominated loans (IMF 2003a). Argentina's external debt grew rapidly and, compared with its meager export base, reached 530 percent of exports by 1999, placing a severe strain on the country's repayment capacity.

Restoring Argentina's external competitiveness proved elusive throughout the 1990s. Since the nominal exchange rate had been irrevocably fixed, the only route to improving competitiveness was through lower inflation. But the labor market was relatively rigid, and in spite of a rise in unemployment after the adoption of the currency board, wage increases did not moderate or decline to facilitate the adjustment process. Toward the end of the 1990s Argentina did begin to experience deflation of consumer prices, but by then the debt buildup had reached problematic levels, and the deflation put further strain on public finances by raising the real value of the debt. When, in addition, the country risk premium began to rise, and markets started to question the operation of the currency board itself, the pressures became unbearable and eventually led to the crisis of 2001, during which Argentina abandoned the currency board and defaulted on its public debt.

After years of high inflation, the currency board arrangement and its extreme rigidity provided a credible monetary anchor for a period of time. But this characteristic also proved to be its key weakness, because the constraints on policies needed to support the rigid exchange rate regime were not respected. Once the currency board had been in place for some time, Argentina was essentially "locked in," and the buildup of dollar-denominated liabilities meant that an abandonment of the currency board would almost certainly undermine public and private debt sustainability.

Sources: IMF (2003a, 2003b).

\section{(C) International Monetary Fund. Not for Redistribution}


to deal with economic and financial imbalances, the usual ups and downs of the business cycle, and unexpected adjustments that may be required due to the ongoing development and liberalization of the economy.

While most emerging market crises have been preceded by an erosion of external competitiveness, it is important to stress that not all current account deficits are problematic or indicative of vulnerabilities. If a developing economy is building up productive industries, or investing in human and physical infrastructure to make industries internationally competitive, then a current account deficit can indicate a healthy development phase that eventually boosts its ability to meet domestic demand, export goods and services, and attract foreign capital. If instead foreign capital is financing an unsustainable rise in domestic consumption, or excessive credit growth that is channeled into real estate or relatively unproductive investments, then the effects of a future capital flow reversal can be severe. While during the Bretton Woods era international financial flows generally mirrored the borrowing needs stemming from a country's current account, in recent decades capital inflows have frequently been a cause of current account deficits by fueling rapid growth of domestic demand.

The experiences of the capital account crises of the 1990s and the new millennium have led many emerging market economies to abandon fully fixed exchange rates. This is not to say that these economies have moved to the other extreme of freely floating exchange rates. Rather, most have opted for so-called managed floats, in which the central bank intervenes if and when it deems necessary (Rogoff and others 2003). In most managed floats the official aim of foreign exchange intervention is to mitigate excessive exchange rate volatility. However, in practice, an additional aim for many emerging markets has been to maintain their exchange rates at relatively "competitive" levels as part of an export-led growth strategy. The success of such a strategy is highly dependent on domestic supply capabilities and on economic developments in the country's main export markets. Emerging market economies that were successful in spurring export growth managed to significantly improve their current accounts at the start of the new millennium as compared with the 1990s. Recently, however, emerging market economies' external positions have come under strain as the advanced economies have slowed substantially in the wake of the global financial crisis (Figure 2.4).

Emerging market economies are likely to have more stable outcomes with a growth strategy that favors a better balance between domestic and external demand and a more diversified output mix (Kose and Prasad 2010). The emerging market crisis experience also highlights the need for policies that shield domestic economies from external shocks. As emerging market economies pursued deeper financial integration after the Asian crisis, they proactively built up international reserves as a buffer against sudden stops (Choi, Sharma, and Strömqvist 2007; Ahmad and Zlate 2013). However, a large stock of foreign reserves can involve sizable costs, since it is invested mostly in safe and liquid 


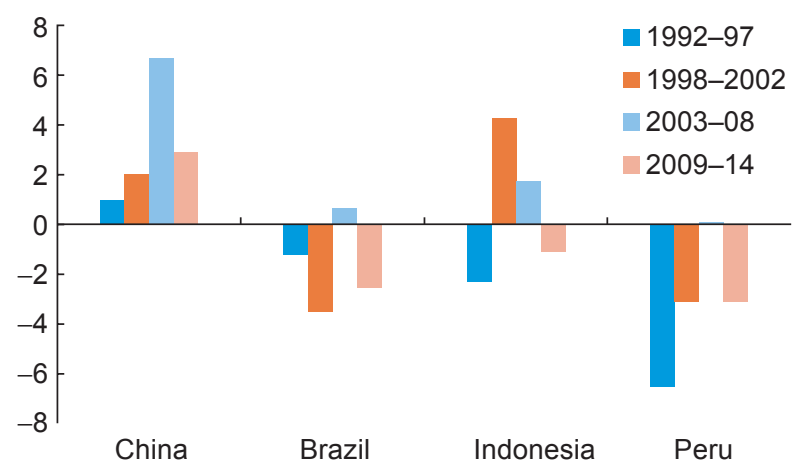

Figure 2.4 Selected Emerging Markets: Current Account (Percent of GDP)

Source: IMF, World Economic Outlook, October 2014.

paper issued by advanced economies, which has yields that are much lower than the returns on domestic investments. Moreover, a relatively depreciated currency depresses the purchasing power of domestic players and constrains the demand for foreign investment goods.

\section{Monetary Autonomy and Institution Building}

In the absence of a fixed exchange rate peg as a nominal anchor, the adoption of an alternative target for monetary policy can enhance the transparency of central bank communication with markets and the public (Bernanke and others 1999). This gives it additional clout in defending its decisions in the face of pressure from the government, industrial lobbies, or other interest groups. Such a target can also provide an internal guideline for central bank policy analysis and formulation. Following the adoption of inflation targeting by a number of advanced economies, many emerging market economies have established inflation targets as the central anchor for their monetary policy (Figure 2.5), and several others are considering doing so in the near future (Reserve Bank of India 2014).

Monetary autonomy has reinforced the need for institution building in emerging market economies. In that sense, the selection of an exchange rate regime is much more than a choice between fixed and floating rates; it is choosing a path for institutional development (Batini and others 2006). A monetary policy framework consists of many facets and its evolution depends on the interaction between a country's economic and institutional progression. Central bank independence may not only require a new law, but also essentially a cultural transformation within the government. There are various ways that the government can exercise power over the central bank, many of which remain even after central bank independence has been legislated. For example, governments retain the 


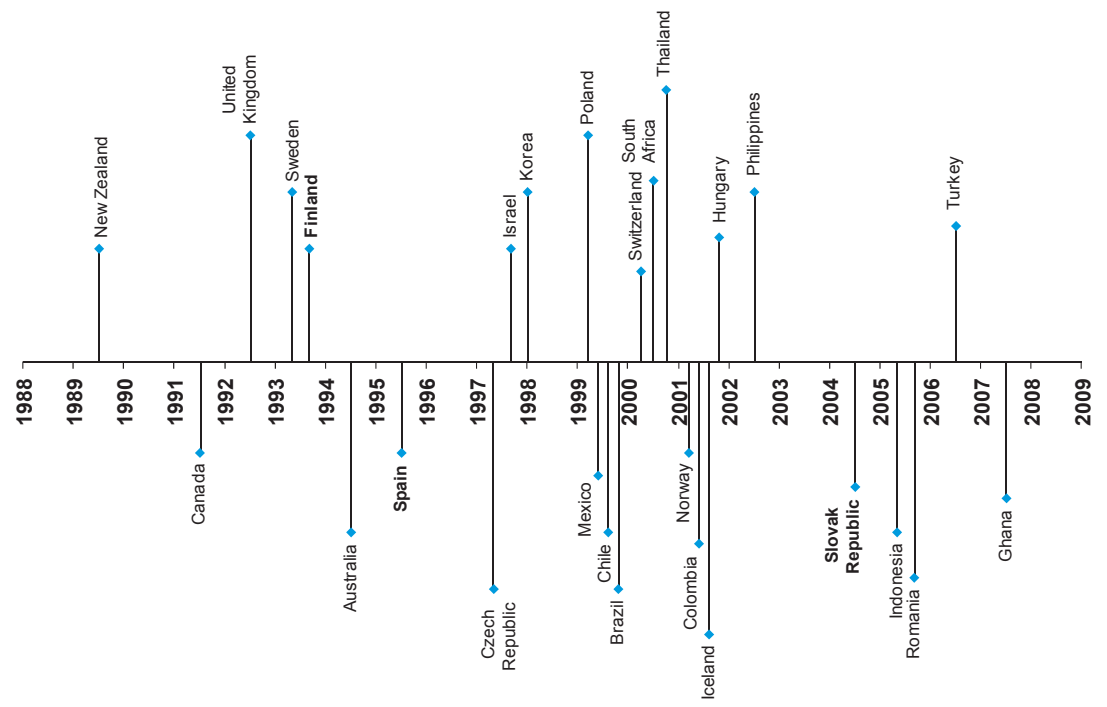

Figure 2.5 Adoption of Inflation-Targeting Frameworks

Source: IMF staff.

Note: Countries in bold have since adopted the euro and are no longer inflation targeters. Countries adopting inflation targeting since 2007 include Albania, Armenia, Georgia, Guatemala, Moldova, Peru, Serbia, and Uruguay.

power to appoint the central bank's governor and, usually, also the rest of the executive board. In addition, government officials can influence central bankers in many tacit ways, for example through control over recapitalization if and when the central bank suffers losses.

The credibility of central banks has been critical to the evolution of effective monetary frameworks (Freedman and Ötker-Robe 2010). Central bank independence requires the creation of an institutional framework that reaches well beyond the doors of the central bank and continues to evolve as a track record is established. Only when it is perceived that the central bank can formulate appropriate monetary policies and hold its own against the Treasury if needed, does central bank independence become credible (Heenan, Peter, and Roger 2006). Essential prerequisites include the building of skills to collect and analyze data, formulate and implement policies in a well-informed way, and communicate effectively with markets and the public at large. Independent policies rely to an important extent on independent thought and foresight, and therefore human capital formation in the central bank is a crucial element in the design of credible monetary policies and their shielding from the political cycle.

\section{Controlling Inflation}

To control inflation, emerging market economies have embraced a variety of frameworks, most of which can be characterized as variations on explicit or implicit inflation-targeting frameworks of the earlier advanced economy 
adopters. ${ }^{7}$ And in implementing these frameworks, emerging market economies have had to deal with a number of challenges. ${ }^{8}$ First, to achieve the established inflation target, the central banks need tools that are able to influence inflation and a reasonably good understanding of how and to what extent these tools can affect domestic prices, the real economy, and the financial sector. Second, indirect monetary instruments such as open market operations require well-functioning and liquid financial markets and some form of collateral that is trusted, tradable, and in plentiful supply. While there has been some deepening of emerging financial markets, this is a recent phenomenon, and money and bond markets remain underdeveloped compared with those of the advanced economies. Since public debt is commonly the collateral underlying open market operations, limited trading in these instruments complicates the implementation of monetary operations. Treasury paper is often held to maturity by commercial banks, pension funds, and official agencies that are required to hold it either by law or through suasion. In some cases, the limited supply of public debt rather than its tradability has prevented its use as collateral.

The policy transmission channels and their effectiveness have been important considerations in the reform of monetary frameworks (Mohanty and Turner 2008). Understanding the impact of instruments on the real economy and the transmission mechanisms-interest rates, credit spreads, asset prices, and exchange rates- has been critical. For example, the U.S. Federal Reserve and the European Central Bank gauge the effectiveness of their monetary operations in normal times by monitoring changes in interbank rates as they transmit policy changes through the financial sector to the rest of the economy. But many emerging market economies have underdeveloped interbank markets and hence the transmission of policy-rate changes may be sluggish or impaired (Coulibaly 2012; Mishra and Montiel 2012). As a result, the impact of monetary operations is often measured through other means, such as the effect on bank deposit and loan rates. These tend to move much more slowly; besides, policy rates also depend on a multitude of other factors-regulations, bank competition, creditworthiness of clients-complicating the analysis of monetary transmission.

Implementing inflation-targeting frameworks in emerging market economies has been significantly more demanding compared to advanced economies and will be particularly difficult in frontier markets. First, determining the level of inflation commensurate with monetary and financial stability is more problematic for countries that are undergoing rapid structural transformations. This occasionally necessitates changes to the inflation target, which can lead to

\footnotetext{
${ }^{7}$ For example, see Bernanke and others (1999); Blejer and others (2000); and Bernanke and Woodford (2005). There is some evidence suggesting that countries with a suitable inflation-targeting framework were better at dealing with some of the disruptions caused by the global financial crisis (de Carvalho Filho 2011).

${ }^{8}$ For example, see Masson, Savastano, and Sharma (1997, 1998); Mishkin (2000); Schaechter, Stone, and Zelmer (2000); Debelle (2001); Amato and Gerlach (2002); Fraga, Goldfajn, and Minella (2003); Stone (2003); Batini and others (2006); De Gregorio (2009); and Hammond, Kanbur, and Prasad (2009).
} 
volatility in market expectations and could be detrimental to anchoring inflation expectations. Second, not only the level but also the type of inflation that the central bank chooses to target is an essential choice in the establishment of an inflation-targeting regime. Central banks are faced with a choice between targeting core or headline inflation (which excludes food and energy prices). Monetary policy tools tend to have a stronger linkage with core rather than headline inflation, as food and energy prices are largely determined on global markets. However, food and energy prices tend to constitute a sizable portion of the consumption basket in emerging market economies, and hence core inflation may have a looser connection to the cost of living for a significant proportion of the public. Box 2.2 discusses how the Republic of Korea grappled with the choice between targeting core and headline inflation and has alternated between different inflation measures.

Emerging market economies using a variety of inflation-targeting frameworks have faced a fundamental tension between pursuing a relatively pure inflationtargeting regime and managing the exchange rate. ${ }^{9}$ While monitoring exchange rate movements is an integral part of inflation targeting for a small, open economy, exchange rate management and large-scale foreign exchange intervention are generally considered inconsistent with a pure inflation-targeting regime (Svensson 2010). In practice, however, emerging market economies with relatively open capital accounts that have an inflation-targeting regime actively manage their exchange rates. ${ }^{10}$ In a sense, the extensive buildup of foreign exchange reserves by various inflation-targeting emerging market economies is itself suggestive of managed exchange rates.

Inflation targeting and active exchange rate management need not be at odds with each other. ${ }^{11}$ The use of the exchange rate instrument makes an inflationtargeting emerging market central bank more rather than less credible. When an emerging market's exchange rate becomes too detached from underlying economic fundamentals, using the interest rate as the sole policy tool places a heavy burden on just one instrument and risks confusing the public. For instance, sharply reducing the policy interest rate in response to an excessive exchange rate appreciation risks pushing inflation above the target, but ignoring such an appreciation is not feasible either, given the central role of the exchange rate in emerging market economies. Given that both inflation and the exchange rate are, in practice, key targets for policymakers, both instruments-interest rate changes and exchange market intervention-have been used.

\footnotetext{
${ }^{9}$ Since the exchange rate is the single most important asset price for a small, open economy, it is unlikely that emerging markets or frontier markets moving toward greater exchange rate flexibility would accept benign neglect of the exchange rate (Eichengreen and others 1999; Mussa and others 2000; Stone and others 2009).

${ }^{10}$ Eichengreen (2004) takes a critical look at the Korean experience.

${ }^{11}$ For example, see Aizenman, Hutchinson, and Noy (2008); Filardo, Ma and Mihaljek (2011); and Ostry, Ghosh, and Chamon (2012).
} 


\section{BOX 2.2 Inflation Targeting in the Republic of Korea}

In 1998, in the wake of the Asian Crisis, the Republic of Korea became one of the first emerging markets to implement an inflation-targeting framework (see Figure 2.4). Although the revised Bank of Korea Act in April 1998 identified price stability as the primary objective of monetary policy, the Bank of Korea did not make the leap to "full-fledged" inflation targeting at once. Rather, it initially specified dual targets-that is, for both inflation and broad money (M3) growth. The reason for keeping the M3 target for a transition period from the earlier monetary targeting framework was to give markets and the public time to adjust to the new regime (Kim and Park 2006).

Initially, the Bank of Korea set an inflation target that was adjustable annually, rather than specifying a fixed medium-term inflation objective (Hoffmaister 1999). The idea of a constant target to facilitate the formation and anchoring of inflation expectations has been central to the inflation-targeting frameworks of advanced economies. However, the adjustability of the annual target provided the Bank of Korea with flexibility that was desirable in the aftermath of the Asian crisis. This flexibility was enhanced by a 1 percent band around the inflation target that provided policymakers with additional room to maneuver in a period of uncertainty. In 1998, the inflation target was set at 9 percent, and in the following year it was lowered to 3 percent. Korean policymakers were willing to sacrifice a bit of the clarity of a single, stable target to ensure a smooth transition to a new regime. The transition was completed by 2001 , the monetary target was relinquished, and the authorities specified a medium-term inflation target accompanied by a narrow band.

In 2001, the Bank of Korea also switched from targeting headline inflation to aiming at core inflation, a decision it reversed in 2007. The change back to headline inflation was due to the difficulties of implementing a core inflation target, which, while more directly affected by domestic monetary policy than headline inflation, is harder to communicate to the public (Inoue, Toyoshima, and Hamori 2012).

Korea's experience with inflation targeting is generally regarded as quite successful in that it has achieved low and stable inflation (Eichengreen 2004). The Bank of Korea has, however, faced challenges in trying to manage both inflation and financial stability. While Korean consumer prices have remained quite stable over the past decade, asset prices, and in particular real estate prices, have risen sharply. The Korean bank's provision of credit, having exhausted the domestic deposit base, has increased its reliance on international wholesale funding markets, and the recourse to short-term, dollar-denominated borrowing has raised concern about currency and maturity mismatches (Ree, Yoon, and Park 2012).

It has been argued that since real estate prices are not included in consumer price indices, focusing only on headline inflation may bring with it the risk of ignoring budding financial imbalances (Reichlin and Baldwin 2013). But adjusting interest rate policy in response to real estate prices, credit growth metrics, or the composition of bank liabilities would be difficult to square with an inflation-targeting framework. The approach taken by the Korean authorities has been to formulate and implement macroprudential measures specifically aimed at preventing the buildup of risks to the financial system. These policies include a levy and a cap on the short-term foreign-denominated liabilities of banks. Bruno and Shin (2014) in analyzing the timing and implementation of such policies conclude that they have been quite successful at limiting the exposure of the Korean banking sector to global liquidity conditions.

\section{CInternational Monetary Fund. Not for Redistribution}


Recent research also suggests that monetary policy in emerging market economies has become increasingly less procyclical, with institutional quality, financial market development, better macroeconomic fundamentals, and the adoption of inflation-targeting frameworks important drivers of this change. Since procyclical macroeconomic policies in emerging market economies have been associated with higher output volatility, success in increasing the countercyclical orientation has led to lower output fluctuations over the cycle and hence large benefits, especially for the relatively poorer segments of emerging market economies. ${ }^{12}$

\section{Macroprudential Policies}

A challenge that inflation-targeting emerging market economies have in common with advanced economies is taking account of financial stability concerns in the setting of monetary policy. The run-up to the global financial crisis saw low consumer price inflation go hand in hand with excessive asset price growth. Policy rates during those years were too low from a financial stability perspective and encouraged the credit creation and leverage that eventually led to trouble (Borio and Zhu 2012). In the crisis aftermath, policymakers facing the zero lower bound of interest rates sought unconventional ways to stimulate economies. Rather than discarding inflation targeting altogether, however, a new consensus has begun to emerge in which inflation targeting is being revised to anchor expectations while economies deal with slow growth, weak banks, and highly indebted public sectors (Reichlin and Baldwin 2013).

Of particular importance in this respect has been the development of macroprudential frameworks aimed at targeting systemic risk. ${ }^{13}$ Macroprudential instruments that directly constrain credit growth, focus on specific markets, such as real estate, or limit certain types of capital flows can supplement the traditional policy toolkit and potentially make it easier to jointly achieve inflation and financial stability objectives. Developing economies, especially in Asia, hampered by nascent markets and murkier market transmission of policies, have not hesitated to use such direct measures in the past. Generally, the application of these tools had been somewhat ad hoc, but in the aftermath of the global financial crisis, emerging market economies too have formalized their macroprudential frameworks (Kawai and Prasad 2011; Lim and others 2011; Nier and others 2011). Frontier economies are also moving in the same direction, and some of them (such as Nigeria and Vietnam) have applied macroprudential remedies to contain financial risks.

As the policymaking institutions evolve, frontier economies would do well to start putting in place a structure for designing and implementing

\footnotetext{
${ }^{12}$ See Lane (2003); and Kaminsky, Reinhart and Végh (2005) on the procyclicality of emerging market macroeconomic policies. Coulibaly (2012); Végh and Vuletin (2012); and McGettigan, Moriyama, and Steinberg (2013) analyze the cyclical nature of emerging market monetary policies.

${ }^{13}$ For example, see White (2006); Borio and Shim (2009); Brunnermeier and others (2009); Hahm and others (2012); and IMF (2012c, 2013e).
} 
macroprudential policy and also widening the perimeter of regulation to encompass the entire financial system, including nonbank financial intermediation. The system of oversight should prevent systemic and sectoral threats from appearing, because once a meltdown starts it is hard to control, given complex interactions, the difficulties of managing expectations under pressure, and the problems of coordinating and implementing policy through multiple agencies.

Although central banks are likely to play a vital role, whether the mandate for conducting macroprudential policy is best placed on the central bank, the treasury, or an independent committee with representation from many agencies - and how the institutional and political structures interact to influence the implementation of policies-remain key questions that only experience will answer (Agur and Sharma 2014). The availability of timely data is a particularly important constraint for frontier markets. And both in terms of data availability and operational implementation, macroprudential policies rely on the capabilities of the banking supervisor. Hence, effective bank regulation and supervision will be an essential requirement for the success of macroprudential policies.

\section{FINANCIAL DEVELOPMENT AND GLOBAL INTEGRATION}

Over the past decade as emerging market economies integrated into the international financial system, they had to deal with larger volumes of capital inflows and outflows (Figure 2.6). In this context, two intricately linked issues arise: the nature and speed of financial sector development and the pace of external financial liberalization. Agricultural imagery may help: removing constraints on capital movements affects how much water flows onto an irrigated tract of land, while financial sector reform and development determine the structure of the irrigation system, including its storage and catchment abilities; a well-constructed irrigation system can deal with greater variability of water flow, but pouring large quantities of water into a poorly built system risks flooding. The structure of the economic system determines whether capital flows have positive or negative effects on growth and financial stability (Box 2.3).

\section{Financial Liberalization}

An overarching question in the context of financial liberalization is the extent to which financial integration promotes growth. In theory, financial integration enhances growth by augmenting domestic savings, lowering the cost of finance, better allocating risk, and facilitating the transfer of technology. However, empirically it has been difficult to establish a robust relationship between financial integration and growth (Bhagwati 1998; Ishii and others 2002; Edison, Levine, and Sløk 2002). This is particularly true in the short to medium term, although there tends to be some consensus on positive long-term effects (Fischer 1998; 


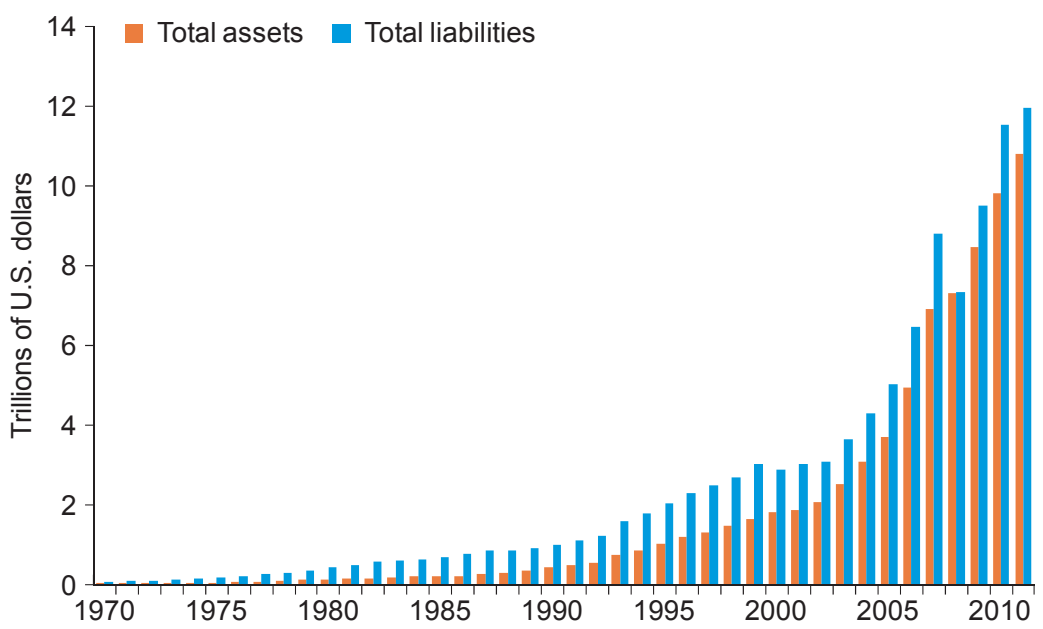

Figure 2.6 Financial Integration: Total Stock of International Assets and Liabilities of Emerging Market Economies and Frontier Economies

Source: Lane and Milesi-Ferretti (2007 and updates).

\section{BOX 2.3 Financial Globalization}

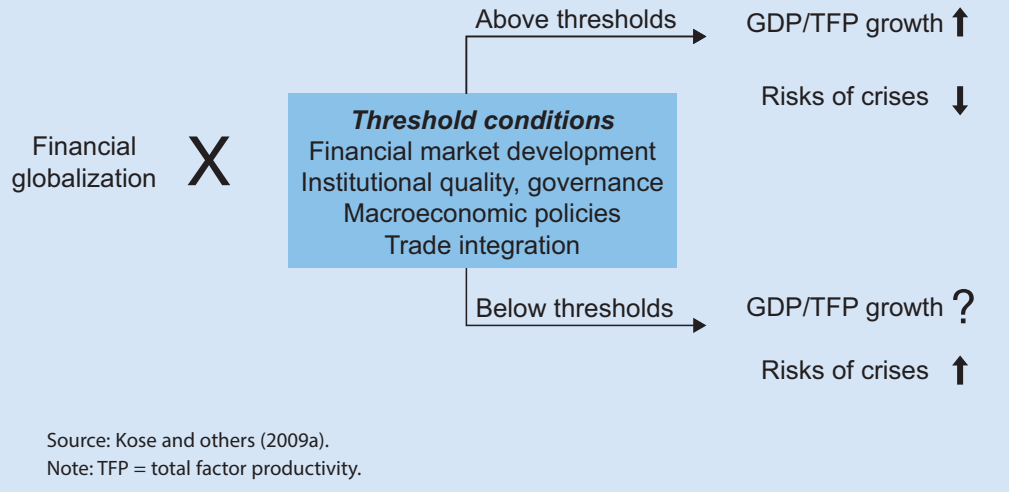

Summers 2000). Threshold effects matter, and the benefits of financial integration are positive only when economies have reached a minimum level of development-capital inflows may be more conducive to economic growth in countries that have good governance, the rule of law, and property rights. International financial integration can also generate "collateral benefits" by imposing discipline on macroeconomic policies, allocating resources better, and making domestic firms more efficient through increased competition (Dell'Ariccia 
and others 2008; Prasad and Rajan 2008; Kose and others 2009a, 2009b; Kose, Prasad, and Taylor 2011).

Financial globalization can also have drawbacks, since it increases a country's exposure to external shocks and policy spillovers from the rest of the world. During the global financial crisis, large two-way movements of capital took place in countries that had more open and developed financial markets. Greater openness to trade and a higher degree of international financial integration were important determinants of the swings in economic activity and capital flows to emerging markets during the global financial crisis (Kose and Prasad 2010; Bunda, Lall, and Sharma 2011). More recently, emerging market economies with relatively large, liquid, and internationally integrated markets were more affected by the U.S. Federal Reserve's "tapering talk" (Eichengreen and Gupta 2014).

Liberalizing too rapidly when the prerequisites are not yet in place risks heightened macroeconomic volatility (Kawai and Prasad 2011). Capital inflows tend to incubate bubbles, which when they burst impair financial stability-they cause asset prices to decline sharply, private credit growth to slow, risk premiums to rise considerably, and exchange rates to depreciate. While in principle access to international capital markets should allow countries to better insure themselves against shocks, experience suggests that premature liberalization may lead to vulnerabilities, especially if currency and maturity mismatches are widespread, risk management is deficient, and financial regulation and supervision are inadequate.

\section{Caution in Liberalizing Capital Flows}

The prevailing wisdom on capital flow liberalization calls for a gradual, pragmatic, and cautious approach. There is no longer a presumption that full liberalization is an appropriate goal for all countries. ${ }^{14}$ Rather, the appropriate degree of liberalization for a country depends on its specific circumstances and on the level of financial development. IMF (2012b) puts forward some basic principles to guide liberalization (see Box 2.4).

A phased process is preferred whereby capital flows that are considered relatively safe and stable are liberalized first. This sequence is often loosely summarized as "long term before short term, non-debt creating (foreign direct investment and equity) before debt, and inflows before outflows." Foreign direct investment (FDI) tends to be much more stable than other types of capital flows, which was underscored by its relative stability during the global financial crisis. Such flows, depending on local conditions, can lead to higher total factor productivity through knowledge spillover, transfers of technology and new management techniques, and linkages with domestic firms. ${ }^{15}$ The Chinese experience

\footnotetext{
${ }^{14}$ See Jeanne, Subramanian, and Williamson (2012), who argue that the use of a diverse set of policies to deal with capital flows is appropriate since there is a lack of strong evidence for or against the benefits of capital account liberalization. They also push for establishing an international regime for capital controls to lessen the stigma attached to such measures and to encourage the use of suitable interventions and discourage those that are inappropriate.

${ }^{15}$ For example, see Alfaro, Kalemli-Ozcan, and Sayek (2009).
} 


\section{BOX 2.4 The Integrated Approach to Capital Flow Liberalization}

- Lifting controls on international capital flows (and financial liberalization more generally) is best undertaken against a backdrop of sound and sustainable macroeconomic policies.

- Financial sector reforms that support and reinforce macroeconomic stabilization should be given priority.

- Financial sector reforms that are operationally linked and mutually reinforcing should be implemented together.

- Prudential regulation and supervision and financial restructuring policies should be implemented to complement other financial reforms aimed at enhancing competitive efficiency and market development.

- The liberalization of capital flows by instruments or sectors should be sequenced to take into account the concomitant risks.

- The pace of reforms should take into account the conditions relating to the financial structure of nonfinancial corporations and other entities (for example, debt-equity ratios and foreign currency exposure) and their effects on the quality of the loan portfolios and capital base of financial institutions.

- Reforms that require substantial lead time for technical preparations and capacity building should be started early.

- Reforms need to take account of the effectiveness of existing capital controls.

- The pace, timing, and sequencing of liberalization need to take account of political and regional considerations.

- The operational and institutional arrangements for policy transparency and data disclosure-including monetary and financial policy transparency-need to be adapted to support capital account opening.

Source: IMF (2012b).

stands out in this respect: joint-venture FDI has often been cited as one of the main sources of successful technology adoption by Chinese companies. However, in recent years the Chinese experience with FDI suggests a note of caution, because a sizable share of it went to the real estate sector, where the potential for technology transfer is small and the likelihood of a bubble is large (Liu 2011).

The IMF's integrated approach identifies three stages for capital flow deregulation (Figure 2.7). During the first, FDI inflows are liberalized while the groundwork is laid for further opening by introducing international accounting standards, improving national statistics, and strengthening the monetary and financial frameworks. The second stage allows for FDI outflows and long-term portfolio flows. Some short-term flows can also be approved at this stage. The last stage eliminates all remaining controls after financial markets are reasonably developed, there is confidence in the management of risks by institutions and market players, and suitable supervision and prudential regulations are in place. Each phase requires a broad set of supporting legal, accounting, financial, and corporate frameworks. For example, India's comparatively strict regulation of short-term debt flows and a preference for flows that do not create debt has reflected financial stability concerns (Mohanty and Turner 2010). South Africa 


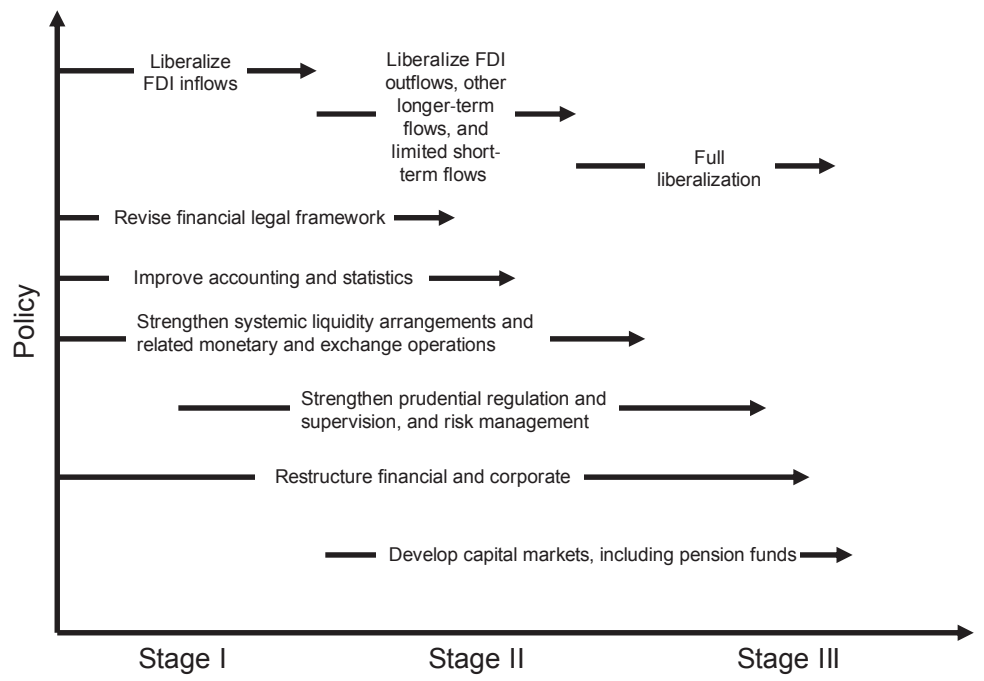

Figure 2.7 Stages of Capital Flow Liberalization

Source: IMF (2012b).

Note: FDI = foreign direct investment.

removed controls on inflows before outflows and gradually lifted restrictions on investments by residents to safeguard reserves and banking stability. Korea is another example of largely successful capital account liberalization over the past few decades (Box 2.5).

In analyzing the recent history of capital flows to emerging market economies and discussing the policy issues raised, Montiel (2013) concludes that a country's resilience in dealing with capital flows depends on a number of factors: (1) the single most important component of resilience is a safe fiscal margin of solvency, underpinned by well-functioning and sound fiscal institutions, government borrowing that is largely long term and in domestic currency, and strong automatic fiscal stabilizers; (2) a well-functioning and regulated financial system that can properly intermediate the capital flows while keeping financial risks in check; (3) a competent central bank that understands the policy transmission mechanisms and can flexibly implement monetary policy free from fiscal dominance and reputational concerns; (4) an exchange rate regime that allows for sufficient exchange rate flexibility to serve as a stabilizing mechanism in the short run and is supported by a large stock of foreign exchange reserves; (5) an institutional and policy environment (including capital account restrictions) that facilitates and encourages relatively stable and safer capital flows, such as FDI and equity flows over short-term debt flows.

\section{Financial Sector Development and Reforms}

Economic growth and financial sector development go hand in hand, and they also help forge a more robust integration with the world economy. The level of 


\section{BOX 2.5 Case Study: Financial Liberalization in Korea}

Over the past two decades or so, the Korean authorities have significantly and successfully liberalized capital flows. Important lessons, however, were learned from the early stages of capital account liberalization, when external sector vulnerabilities built up and led to a financial crisis in 1997-98. During 1988-96, a range of reforms were implemented to develop financial markets, and this was accompanied by a loosening of capital account restrictions. Capital flows financed an investment boom, and short-term external debt rose from $\$ 40$ billion in 1993 to about $\$ 100$ billion at the end of September 1997. The sharp decline in reserve coverage due to the growth of short-term debt contributed to the liquidity crisis in 1997-98. In the aftermath of the Asian financial crisis, Korean policymakers followed the "integrated approach" to capital account liberalization in several respects, with specific attention to financial market regulation, adequate safeguards, and corporate governance.

Since the early 1990s, Korea has gradually eliminated capital controls with the objective of achieving a degree of openness associated with Organisation for Economic Co-operation and Development countries.

- Liberalization proceeded generally against a backdrop of broadly sound, sustainable, and consistent macroeconomic policies anchored around prudent fiscal policies, a flexible exchange rate regime, and monetary policy under inflation targeting.

- Financial sector reforms were given priority with the development of a local currency bond market and a framework for securitization.

- Financial sector development was reinforced by enhancing the transparency of the foreign exchange market through strengthening disclosure requirements and accounting standards.

- Financial sector regulation was strengthened in preparation for, and during, capital flow liberalization. For example, the authorities put in place strict liquidity requirements in the context of implementing Basel II rules.

- Less risky flows were liberalized before more risky ones. For example, restrictions on longer-term flows such as foreign direct investment (except for certain sectors) were removed first along with those on certain portfolio investments.

The gradual transition to a more open financial system by and large served Korea well, despite occasional surges in capital inflows and outflows. Despite the cautious approach, the banking system accumulated substantial forward foreign exchange positions and short-term external debt in the wholesale funding market and became highly leveraged. During the global financial crisis, Korea experienced a "sudden stop" as access to short-term external financing dried up abruptly and banks had difficulty rolling over their debt. The Korean authorities subsequently introduced measures (including macroprudential regulations) to prevent a renewed buildup of financial sector vulnerabilities and limit the associated potential for macroeconomic volatility. A key lesson from the Korean financial liberalization experience is that regulation and supervision of the banking system and of capital and derivatives markets must be continuously recalibrated to keep up with liberalization and the introduction of new financial instruments.

Source: IMF (2012d).

financial development can also influence a country's choice of macroeconomic policy regime (such as exchange rate and monetary frameworks) and the efficacy of policy implementation. Countries with deeper markets are more likely to have flexible exchange rates and use indirect instruments of monetary policy and more 
effective countercyclical fiscal policies (although the causation can run both ways). And even after controlling for financial crises, exchange rate flexibility in the presence of reasonably developed financial markets and a well-regulated banking system is often associated with lower aggregate macroeconomic volatility (IMF 2013a).

Recent experience of emerging market economies suggests that the development of frontier economies will need to be managed carefully because information and regulatory gaps will undoubtedly emerge. Simpler financial instruments will need to be introduced first, and reform may require parallel changes in interrelated markets and policies to foster development of the system as a whole. ${ }^{16}$ Institutional mechanisms will have to be created to lower and contain the frictions associated with information, monitoring, and enforcement costs. In the initial stages, governments will have to put in place the basic infrastructure (such as payment and settlement systems, trading platforms, and custodians for securities) to support financial markets, strengthen the rules that foster development, and rewrite or remove those that hinder it. Policies will have to evolve with technological progress and the changing needs of growing economies, with the objective of creating a competitive system that allows for innovation but is properly regulated and supervised.

There should be sufficient recognition of the inherent market failures associated with financial markets and the identification of specific frictions to alleviate in different economies. The management and control of risks will have to rely on a diversity of instruments that complement each other, rather than on a single instrument. The regulatory strategy should have two prongs: alter incentives so that private and social returns are better aligned and, when necessary, impose direct constraints that limit inappropriate risk taking by managers and owners of financial institutions (Stiglitz 2001). For example, despite the "risk adjustments" in capital adequacy calculations, sometimes ceilings on bank deposit rates may be required to prevent banks from taking on additional risk while touting the safety provided by deposit insurance or other government guarantees. It is important to recognize that supervising risk-management systems is difficult even in developed economies, let alone in emerging market and frontier economies. Traditional constraints on banks, such as rules on capital and loan-loss reserves, may be difficult to monitor and enforce, especially if the financial system is in transition and regulatory institutions are weak. Hence, regulators in frontier economies may have to rely on direct constraints on collateral requirements and valuation, restrictions on loan categories (such as residential and commercial real estate loans), interest rates, and even entry into markets (such as eligibility rules for owning and running banks and capital market intermediaries).

An important lesson of the Asian crisis was that liberalizing the financial sector before an appropriate regulatory system is in place is a recipe for trouble. Regulatory agencies will have to be given the legal authority and independence to

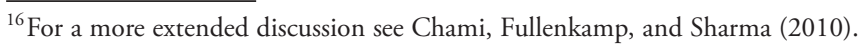


do their job while being held accountable for outcomes. However, during transition and development, frontier economies will have to live with the fact that it takes time to build regulatory institutions and capacity and strengthen financial sector oversight. They will have to face the scarcity of human capital and trained personnel in both the private and public sectors. Managers of financial institutions may not be well versed in comprehending and managing the risks of new financial instruments or even those of traditional instruments in more liberal and competitive markets. Regulatory cadres are difficult to cultivate when access to good schooling is limited and universities do not provide the quality of education needed to function in the new domestic and international environments. With limits on remuneration in the public sector, official agencies also have to contend with competing with the private sector for scarce talent.

Recent crises also highlight the importance of maintaining public confidence in the banking system. After the Asian crisis, most countries in the region adopted explicit deposit insurance schemes to provide a basic level of protection for small depositors (Lindgren and others 1999). And better resolution regimes for dealing with bank failures supplemented the lender-of-last-resort function of central banks. Frontier economies will have to manage the incentives created for banks' risk taking with appropriate oversight and constraints and appropriate pricing of government guarantees. ${ }^{17}$ With financial markets still at a nascent stage, crossborder flows will be channeled through global and regional banks, and experience suggests that such flows are likely to be highly procyclical. To assess threats to financial stability, focusing on net flows is not enough, and it is important that frontier economies build systems to keep track of gross cross-border flows and gross external assets and liabilities. ${ }^{18}$

In the past decade, Asian emerging market economies have focused considerable attention on developing domestic debt markets, and more generally diversifying the financial system, to reduce foreign exchange mismatches in their financial systems and to decrease the concentration of risks in banks. Domestic debt markets are seen as providing funds for government and private sector needs and large infrastructure requirements and as another important channel for financial intermediation should the banks get into a mess. For now, the equity culture coupled with the comfortable liquidity positions of banks and corporations are hurdles for the expansion of local bond markets. However, in some countries (such as China and India), economic growth has begun to catalyze a shift toward broader capital market development as the demand for corporate and household credit rises.

Despite the expansion of local debt markets, progress needs to be made on several fronts (Goswami and Sharma 2011). These include improvements in market access and infrastructure, transparency, risk assessment and management

\footnotetext{
${ }^{17}$ Acharya (2013) in assessing the U.S. Dodd-Frank Act and drawing lessons for emerging market economies highlights the risk-taking incentives created by explicit and implicit government guarantees and the need to contain and manage the competitive distortions and moral hazard they create.

${ }^{18}$ See Committee on International Economic Policy and Reform (2012).
} 
by financial institutions, the legal and regulatory framework, and market liquidity. The major barriers to debt market development include the following:

- Bank dominance

- Lack of critical size in issuance

- Lack of a diverse investor base and preponderance of buy-and-hold investors

- An embryonic legal and regulatory framework for nonbank financial institutions

- Tax and capital controls on foreign investors

- Weak corporate governance

- Inadequate information provision, including pricing transparency, and infrastructure issues

- High issuance and transaction costs

- Lack of pricing benchmarks and hedging instruments

- Lack of a robust framework for asset-backed securitization

Bank dependence can be reduced in emerging market and frontier economies by improving confidence in the regulatory, supervisory, and enforcement frameworks for capital markets and nonbank financial institutions. For capital markets to function effectively, sufficient information to assess credit risks adequately is critical. Credible rating systems, appropriate reporting requirements, and adoption of international accounting standards are helping to foster market discipline. Emerging market economies are rationalizing and consolidating the supervision of nonbank financial institutions to increase effectiveness and reduce the scope for regulatory arbitrage. In 2009, for example, Korea implemented a new framework for the financial investment industry (Financial Investment Services and Capital Market Act) that consolidates the oversight of all capital-market-related institutions. The new framework adopts a functional approach to regulation in which financial functions are similarly regulated irrespective of the institution in which they are performed.

Given the part played by shadow banking in the global financial crisisfacilitating credit provision, leverage, and financial layering in the system-the Financial Stability Board is encouraging country authorities to define and assess the role of nonbank financial intermediaries in their financial systems (Financial Stability Board 2011, 2012, 2013). Countries are being asked to improve the granularity and quality of information available on the balance sheets, operations, and risk management processes of nonbank financial intermediaries, with a view to understanding the functions they are performing and their links to banks and money and capital markets. The objective is to prevent regulatory arbitrage and examine to what extent nonbank financial intermediaries could contribute to the production and propagation of systemic risks. In recent years, the rapid expansion of the shadow banking sector in China has raised concern about financial stability, due to the variable quality of nonbank financial intermediaries' loans, and 
their packaging into wealth-management products offered by banks and trusts to institutional and retail customers.

Asset-backed securitization in Asian emerging market economies is eventually likely to be driven by the desire to enhance liquidity in the banking system as disintermediation gathers pace, and to meet the funding needs of the real economy rather than balance sheet arbitrage (Lejot, Arner, and Schou-Zibell 2008). Illiquid assets like mortgage and consumer loans could be securitized as capital markets develop and securitization frameworks, including for covered bonds, are established. This should increase the size of private bond markets and provide institutional investors with a more diverse set of instruments as assets are created from infrastructure investments, commercial real estate, housing, and household borrowing.

A well-diversified domestic and foreign institutional investor base (pension, insurance, mutual funds) is required to support capital market development by increasing the demand for long-term financial assets. A broad base of domestic investors, besides increasing the liquidity and depth of local bond markets, may increase an economy's ability to handle capital flows triggered by external events. Banks holding large portfolios of government bonds are exposed to interest rate volatility and sovereign risk, and longer-term infrastructure lending aggravates maturity mismatches. To maintain their franchise value, greater diversification of revenue sources for banks is required, coupled with more prudent credit risk assessments.

Financial depth and inclusion are related but distinct dimensions of financial development, and financial systems can become deep without delivering access for all (Demirgüç-Kunt and Klapper 2013). While financial sectors in emerging market and frontier economies have expanded over the past few decades, lowincome households and small firms continue to find it difficult to access financial services. Lack of access to finance is a major impediment in many parts of Asia, where more than half the population and a significant proportion of small and medium-sized enterprises have no connection to the formal financial system (Balakrishnan, Steinberg, and Syed 2013). Financial development that broadens access to finance can benefit the poor disproportionately because market imperfections-asymmetric information and the costs associated with transactions and contract enforcement-hit poor and small-scale entrepreneurs hardest as they typically lack collateral, credit histories, and connections. Through recourse to financial services, individuals can build their assets, invest in human capital, and improve their standard of living (Allen and others 2013).

\section{FISCAL POLICIES}

The concept of sustainability is central to any framework for designing and implementing fiscal policy. High and unsustainable debt levels tend to dampen economic growth by raising interest rates and crowding out private sector investments. Sustainability implies that the government can continue to service its debt without an expectation that a large correction will be necessary to balance revenues and expenditures in the future. In emerging market economies, the fiscal challenges are defined by a small tax base, a tax administration system that is unable to fully collect taxes and other levies, and a greater vulnerability to external

\section{(C) International Monetary Fund. Not for Redistribution}


shocks, especially for governments with sizable foreign-currency-denominated debt. High public debt and persistent deficits also accentuate the links between fiscal and monetary policy, leading to fiscal dominance that undermines the credibility of monetary policy.

Fiscal policy in frontier economies should be supportive of growth, employment, and equity. ${ }^{19}$ Historical experience suggests that without robust economic growth it is difficult to provide public goods while keeping debt ratios down. With steady growth, productive investments in education, infrastructure, health care, legal and judicial services, and regulatory systems can be made without imposing onerous burdens on firms and households. In addition, equity considerations require the government to have an efficient and effective social safety net that targets the benefits to low-income households.

\section{The Role of Fiscal Institutions}

The purpose of fiscal institutions is to establish incentives and constraints that induce policymakers to promote long-term solvency and create fiscal space for short-term stabilization needs. In the fiscal domain (revenue collection, government spending, debt management), developing economies (and some postcrisis developed economies) have been striving to create well-functioning fiscal institutions that mitigate discretionary spending biases arising from the "common pool problem" as competing groups vie for government expenditures financed through broad-based tax revenues. Because benefits are concentrated-whereas costs are widely dispersed - this tends to lead to overspending.

Such biases can also result from conflict between the long- and short-term objectives of fiscal policy. The long-term objective is to maintain socially useful expenditure programs in a manner consistent with debt sustainability. In the short run, however, governments often aim to stabilize output while simultaneously facing pressures arising from electoral cycles. An excessive focus on shortterm considerations can result in procyclical spending patterns as well as structural budget deficits over time. If the degree of fiscal discretion in the budget process is the main problem, then discretion can be constrained by fiscal rules or alternatively delegated to independent fiscal agencies. ${ }^{20}$

\footnotetext{
${ }^{19}$ The impact of redistributive fiscal instruments on economic efficiency depends on their design, and fiscal redistribution need not have any direct effect on growth (IMF 2014; Ostry, Berg, and Tsangarides 2014). See also Dreze and Sen (2013), who argue that in India the underdevelopment of social and physical infrastructure and the neglect of human capabilities threaten the sustainability of high economic growth. Stiglitz (2012) draws out the implications of increasing inequality for monetary and fiscal policies, democracy, and globalization.

${ }^{20}$ The legal foundations of rules take various forms. In Germany, Poland, and Switzerland, rules are embedded in constitutional law, which confers a special weight since it is difficult to change the constitution. Some emerging markets have followed this approach, and the rules are based on statutory norms (acts of Parliament). For example, Sri Lanka introduced a Fiscal Management Responsibility Act in 2003, and Pakistan enacted a Fiscal Responsibility and Debt Limitation Act in 2005, both of which covered the general government and stipulated rules for budget balances and debt. But in other cases, rules have been established by political commitment—-for example, in an agreement among partners in a governing coalition (Indonesia and the Netherlands are examples).
}

CInternational Monetary Fund. Not for Redistribution 


\section{BOX 2.6 Chile's Fiscal Rules}

An important macro-fiscal challenge for some frontier economies is the effective management of natural resource revenues over commodity cycles. Chile offers an interesting example of a resource-rich economy (as the world's prime producer and exporter of copper) that has prudently managed its natural resource revenues while achieving a reasonable degree of economic diversification. During 1986-98, Chile had GDP growth rates averaging 7.3 percent, similar to those of the so-called Asian tigers. While harnessing its copper wealth judiciously, Chile managed to diversify its economy and develop industries that reduced its reliance on copper, with the share of mining declining from about 90 percent of Chilean exports in the early 1970s to about 40 percent by 2001.

The central pillar of macroeconomic policy prudence in Chile has been the successful implementation of fiscal rules to manage copper revenues through the business cycle. Since the mid-1980s, successive governments have maintained a cyclically adjusted budget surplus. This was first implemented through an implicit fiscal rule, and, beginning in 2001, with an explicit fiscal surplus target (structural revenues minus expenditures) of 1 percent of GDP. Two panels of independent economic experts are asked to produce projections from which the potential output and the copper reference price are calculated by simple averaging (excluding outliers). In May 2007, when central government debt had declined to only 4 percent from 45 percent in 1990, the surplus target was lowered to 0.5 percent, releasing funds for increased spending on education.

In 2006, the Fiscal Responsibility Law further strengthened the fiscal structure. The budget surplus target was authorized by law and the surplus earnings apportioned to the Economic and Social Stabilization Fund, the Pensions Reserve Fund, and the Contingency Unemployment Program. The two funds, managed by the central bank on behalf of the government, make both domestic and foreign investments, and the authorities are fully aware of the virtues of automatic sterilization if the funds are invested abroad.

Source: Havro and Santiso (2008).

Given that some frontier economies are commodity dependent, managing commodity price volatility is an important challenge for fiscal policy. Chile appears to be at one end of a spectrum of countries that have successfully avoided procyclical policies, whereas Argentina and Venezuela are at the other end, with fiscal policies accentuating business and commodity cycles. To avoid overspending during booms and periods of buoyant commodity prices, Chile has implemented a fiscal rule that targets a constant structural balance after adjusting for commodity price volatility and cyclical fluctuations in GDP (see Box 2.6).

Fiscal rules cannot substitute for political will, but they have gained prominence as tools to correct or limit distortions stemming from political shortsightedness and the common-pool problem. Fiscal rules have spread worldwide and have been increasingly adopted by emerging market economies. A recent IMF survey showed that 76 countries, many of which are emerging market economies, had fiscal rules, up from 5 in 1990 (Schaechter and others 2012). ${ }^{21}$

\footnotetext{
${ }^{21}$ Broadly speaking, there are four types of rules. First, budget balance rules can be applied to the overall balance, the primary balance or the cyclically adjusted (structural) balance. Second, debt rules set explicit limits or targets for the debt-to-GDP ratio. Third, expenditure rules set limits on spending in absolute terms, in growth rates, or as a percent of GDP, often over a multiyear horizon. Fourth, revenue rules set floors or ceilings aimed at boosting revenues or constraining the tax burden.
} 
For example, the Fiscal Responsibility Law introduced in Brazil in 2000 established policy rules consisting of limits and targets for selected fiscal indicators for all levels of government, including debt ceilings and transparency requirements.

One lesson from the global financial crisis is that fiscal rules should be made more binding in good economic times, while allowing room to maneuver when the economy is weak. Such rules tend to explicitly combine the sustainability objective with more flexibility to accommodate economic shocks by targeting structural balances and accounting for the cycle. National rules that provide some flexibility, either by accounting for the cycle (such as in Australia or Switzerland) or by including explicit escape clauses (Brazil), generally fared better. Empirical studies suggest that fiscal rules have played a supportive role in several cases of large fiscal adjustments (Debrun and others 2008). But rules may often come with weak political commitment, and quite often countries may not have the prerequisites to implement them, which can undermine credibility. Simple fiscal rules that rely on nominal variables are often procyclical and lack the flexibility to accommodate major shocks, which makes it more difficult to enforce them. Rules may also encourage creative accounting, including the setting up of off-budget entities (Irwin 2012).

Enforcement mechanisms and other arrangements supporting the implementation of fiscal rules are not easy to put in place. Fiscal councils can be important tools to enforce fiscal rules. They are publicly funded independent bodies with a mandate from elected officials to provide nonpartisan oversight, analysis, or advice on fiscal policy and performance. The apparent success of central bank independence has raised the idea of delegating some aspects of fiscal policy to independent fiscal agencies. No country has as yet established a truly independent fiscal authority. However, some countries (such as Chile, Korea, the United Kingdom, and the United States) have established fiscal councils that, while leaving decision-making authority in the hands of the government, provide independent budget projections, as well as assessments of policy consistency with long-term objectives and proposals for adjustment, if required. The National Assembly Budget Office in Korea examines all aspects of fiscal policy of interest to the Parliament and reviews fiscal plans, prepares alternative macro-fiscal projections, and appraises major projects (Cangiano, Curristine, and Lazare 2013). That said, the success of a fiscal council depends on a reputation for political neutrality. Political interference, or a perception of it, can quickly undermine its credibility and usefulness.

\section{Fiscal Risks}

Underestimation of fiscal risks from macroeconomic shocks and contingent liabilities continue to be an important policy issue (IMF 2013d). The experience of Ireland and Spain recently made it clear that the materialization of contingent liabilities can add significantly to public debt and quickly raise questions about sustainability. The recapitalization of banking systems, in particular, has proved costly, and government guarantees on private sector projects are a further source 
of risk. Indonesia's bank recapitalization in response to the Asian crisis of 1997-98 proved very costly. Total net cost was about 52 percent of GDP, with recoveries from asset sales and workouts totaling less than 5 percent of GDP. In contrast, for Malaysia, where banking supervision was tighter and which experienced smaller exchange rate depreciation during 1998-99, the cost of backstopping the banking system was much lower at about 5 percent of GDP (Greene 2012).

Assessing the size and likelihood of bearing contingent liabilities is therefore an important step in improving fiscal transparency. This contributes to a better understanding of an underlying fiscal position and related risks. The decade before the global financial crisis saw a concerted effort to develop a set of internationally accepted standards for fiscal transparency. The comprehensiveness, quality, and timeliness of public financial reporting in countries across the income scale also steadily improved. Despite precrisis advances, shortcomings in fiscal disclosure resulted in an inadequate understanding of underlying fiscal positions and fiscal risks. Several countries experienced large unexpected increases in deficits and debt as a result.

Fiscal risks from shortcomings in fiscal disclosure are mainly due to the narrow scope of fiscal reporting or weak compliance with fiscal transparency standards. Most countries report fiscal variables for the general government. However, this excludes a range of entities outside the general government perimeter whose activities can have fiscal implications. Lack of timely and accurate in-year fiscal data can lead to substantial revisions of initial estimates for general government debt and deficits, and large revisions can render a fiscal adjustment plan out of date shortly after approval.

The IMF's Fiscal Transparency Code, Manual, and Assessment have been updated to reflect the lessons from the crisis. The following reforms are going to be critical: (1) broadening the institutional coverage of fiscal reports, (2) providing balance sheet information, (3) increasing the frequency of fiscal reporting, (4) requiring greater disclosure and management of contingent liabilities, and (5) increasing the consistency between forecast, in-year, and year-end fiscal data.

There is some evidence that the disclosure of fiscal risks can strengthen confidence, lead to better sovereign bond ratings, and facilitate greater access to international capital markets (Cebotari and others 2009). The Fiscal Policy Office within the Indonesian Ministry of Finance prepares a fiscal risk statement that is included in the annual budget documents-making Indonesia one of the pioneers in fiscal risk analysis among emerging market economies (IMF 2010). The fiscal risk statement covers (1) sensitivity analysis of the state budget and the budgetary impact of state-owned enterprises to variations in key macroeconomic assumptions; (2) public debt risk of the central government; (3) contingent liabilities of the central government related to infrastructure development projects, civil service pensions, the financial sector, legal claims on the government, membership in international financial organizations and agencies, and natural disasters; (4) risks related to fiscal decentralization; and (5) other risks. 


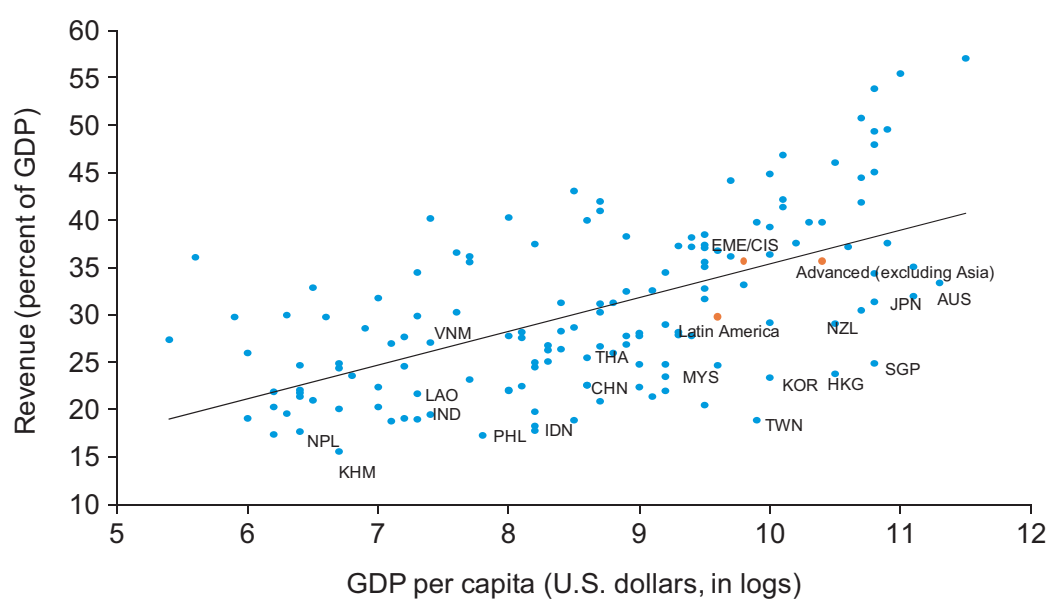

Figure 2.8 General Government Revenue and GDP per Capita, 2011

Source: IMF (2013a).

Note: AUS = Australia; KHM = Cambodia; $C H N=$ China; HKG = Hong Kong SAR; IND = India; IDN = Indonesia; JPN = Japan; KOR = Korea; LAO = LAO P.D.R.; MYS = Malaysia; NPL = Nepal; NZL = New Zealand; PHL = the Philippines; $\mathrm{SGP}=$ Singapore; $\mathrm{TWN}=$ Taiwan Province of China; THA = Thailand; VNM = Vietnam. EME/CIS = Emerging Europe and Commonwealth of Independent States.

\section{Public Debt}

Potential risks associated with high public debt have long been a concern of emerging market policymakers, as these can force painful adjustments that hamper economic performance. The rise in emerging market public debt can be attributed to a number of features in their fiscal and public debt structures that have important implications for debt sustainability. First, revenue ratios in emerging markets are low, because effective tax rates are generally much lower than in advanced economies. This low effective tax rate is the result of inefficient tax systems, significant tax exemptions, and a large informal sector. For example, in Asian emerging market economies and low-income countries, the average ratio of revenues to GDP in 2011 was 19 percent, compared with 30 percent in Latin America and 37 percent in emerging Europe and Commonwealth of Independent States countries (Figure 2.8). Second, revenues in emerging market economies tend to be volatile, partly due to the greater underlying volatility of the economy, income, consumption, and the terms of trade. Third, interest costs account for a high proportion of government expenditure in emerging market economies and are more variable because a large proportion of debt is denominated in foreign currency while revenues are in domestic currency with high exchange rate volatility. For small, open emerging market economies, this can result in large spikes in interest (and principal) payments relative to government income when the domestic currency depreciates. Furthermore, domestic debt often has shorter maturity, making the interest costs more sensitive to changes in domestic credit conditions. 
Public debt in emerging market economies has risen quite sharply since the mid-1990s, and averaged about 70 percent of GDP in 2002. It was concentrated in Latin America and emerging Asia, with the latter seeing a notable rise due to the impact of the Asian crisis-debt-to-GDP ratios rose significantly within a year or so of a crisis (by about 20 percent of GDP in Mexico and Thailand and about 15 percent in the Republic of Korea-Hemming, Kell, and Schimmelpfennig 2003). Interest and exchange rate movements combined with the realization of off-balance-sheet and contingent liabilities drove the rise in emerging market public debt. In a number of countries (Indonesia, Korea, Thailand), the cost of recapitalizing banking systems was particularly high (IMF 2003b).

Emerging market economies with high public debt have a mixed track record on sovereign debt default. The countries that have defaulted do have, on average, a higher ratio of public debt to GDP, but they also have a higher proportion of external debt in total public debt and a lower ratio of broad money to GDP than countries that did not default. Indeed, in a number of cases overvalued exchange rates held down the debt ratios prior to a crisis, given the share of foreigncurrency-denominated public debt. Most of the cases of sovereign debt default occurred during the 1980s and early 1990s, when several of these economies had experienced a significant loss of international competitiveness but did not necessarily have high public debt levels. In contrast, emerging market economies, such as India, have managed to maintain relatively high public debt for a long period without a default.

Arriving at an optimal composition of the public debt, depends on a country's circumstances, but generally involves a trade-off between maintaining a government's anti-inflationary credibility and decreasing the vulnerability of the budget to macroeconomic and financial shocks. Sovereigns that have anti-inflationary credibility favor long-term nominal securities, while those that do not may have to settle for indexed debt of varying maturities. Further, to retain market access for a spectrum of needs and catalyze domestic financial market development governments should try to fund themselves with a wide variety of securities (Montiel 2005).

\section{Fiscal Reforms}

A sustainable debt level implies that the government's intertemporal budget constraint is satisfied without an expectation that an unrealistically large future correction in the primary balance will be necessary (IMF 2002). Solvency must therefore be viewed in relation to a fiscal (adjustment) path that is both economically and politically feasible. In addition, liquidity conditions are also important - that is, even if a government satisfies its present-value budget constraint, it may not have sufficient assets and financing available to meet its maturing liabilities.

- Tax reforms and expenditure control: Reforms to strengthen and broaden the tax base are needed so that governments have access to higher and less 
variable revenues. Better control of expenditures during economic upswings is also essential to ensure that periods of strong revenue growth result in higher primary surpluses rather than increased spending. ${ }^{22}$ Since the early 1990s, developing economies (Mozambique, Peru, Rwanda, Tanzania, and Vietnam, for instance) have implemented wide-ranging tax administration reforms (IMF 2011). In Indonesia, tax administration reform was important for fiscal adjustment, and about half the tax revenue increase of 1.1 percent of GDP over the reform period 2002-06. Effective tax rates in emerging markets are still generally low, suggesting that tax avoidancethrough either legal or illegal means-and weak tax administration are serious issues that need to be addressed. For example, the value-added tax (VAT) gap, defined as VAT revenue with full compliance minus actual VAT collection has been estimated at 51 percent in Indonesia compared with 13 percent in the United Kingdom (Brondolo and others 2008). The continued reliance on taxes and transfers related to commodity exports is a weakness of many current tax systems, and efforts are needed to broaden the tax base to reduce its variability.

- Structural and expenditure reforms to boost growth: Historical experience suggests that it is difficult to bring public debt ratios down without robust economic growth. And appropriately formulated revenue and expenditure policies can deliver growth-enhancing public services while minimizing growth-retarding distortions in the economy. For example, expenditures on education, research and development, and productive investment have shown the greatest potential growth dividends. Energy subsidy reform and better targeting of social benefits can free up resources to finance the required spending. Reforming fuel subsidies has been a persistent policy challenge in many emerging market economies, including Indonesia and Malaysia (Figure 2.9). The IMF, in "Energy Subsidy Reform: Lessons and Implications" distills six key ingredients of a successful energy subsidy reform from country case studies: (1) The plan should be comprehensive. (2) Reform should be accompanied by a far-reaching communications strategy, aided by improvements in transparency. (3) Energy price increases can be appropriately phased and sequenced differently across energy products. (4) producer subsidies can be reduced by improving the efficiency of stateowned enterprises. (5) The poor should be protected by targeted mitigating measures. (6) Energy pricing should be depoliticized to prevent the recurrence of subsidies. An important lesson learned is that the targeting of cash transfers and effectively communicating the objectives and planned mitigating measures to the public can promote the acceptance of reforms (IMF 2013b, 2013c). Recently, governments in Argentina, Brazil, Chile,

\footnotetext{
${ }^{22}$ Frankel, Végh and Vuletin (2013); and IMF (2013a, Chapter 2) show that strong institutions are a key determinant of a developing economy's ability to conduct countercyclical fiscal policy. Fatás and Mihov (2013) provide evidence that the volatility of fiscal policy can exert a negative effect on longterm economic growth.
} 


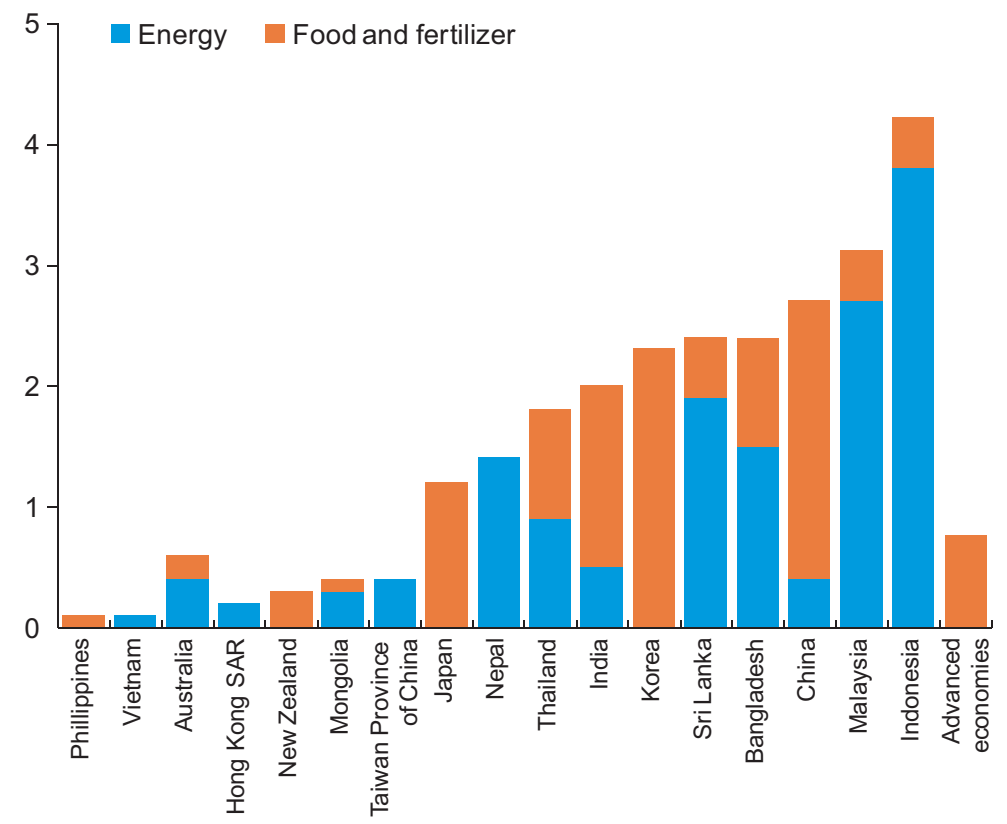

Figure 2.9 Food and Energy Subsidies, 2012 (Percent of GDP) Source: IMF (2013a).

and Mexico made an effort to better focus public transfers. To improve outcomes, cash transfers for facilitating the development of human capital among the poor were made conditional on school attendance and vaccinations (Tanzi 2011).

- Reducing exposure to exchange rate and interest rate movements: emerging market economies used to be highly exposed to interest rate and foreign exchange rate risk, because much of the foreign borrowing came in the form of short-term foreign-denominated debt. The growth of local currency debt markets over the past decade has lessened these currency mismatches and has also raised the duration of the public debt. However, some emerging market economies (Argentina, Turkey) still have high short-term external debt in comparison with their international reserves. Further development of local currency bond markets, possibly in conjunction with macroprudential measures to discourage excessive reliance on short-term external debt, can help extend the gains of the past decade.

- Acknowledging contingent liabilities: Recent crises have shown that the realization of contingent liabilities can significantly add to public debt and quickly raise questions about sustainability. Indonesia's bank recapitalization in response to the Asian crisis of 1997-98 was very expensive for the public 
exchequer. More recently, the recapitalization of banking systems in some euro area countries has proved to be costly, and government guarantees on private sector projects have been a further source of risk. Assessing the size and likelihood of bearing contingent liabilities is therefore an important step in improving fiscal transparency. Strengthening financial sector supervision is crucial to achieving this goal.

- Steps to improve the credibility of fiscal policy: Building credibility requires not only the implementation of effective fiscal reforms, but also a record of adhering to new arrangements through upturns and downturns. The strengthening of fiscal institutions has a very important role to play in this regard. Fiscal rules - broadly defined as permanent constraints on fiscal performance-in some cases may play a useful role in strengthening fiscal policy credibility if appropriately designed and obeyed. For example, the Fiscal Responsibility Law introduced in Brazil in 2000-which established policy rules consisting of limits and targets for selected fiscal indicators for all levels of government, including debt ceilings and transparency requirements-appears to have helped strengthen the government's credibility in financial markets.

\section{Fiscal Problems and Financial Crises}

As recent experience has shown, financial crises can have a dramatic effect on a country's fiscal situation. Cross-country empirical studies show that fiscal variables are indeed correlated with crises. A review of the theoretical literature suggests that there are three main channels by which fiscal policy can precipitate a financial crisis (Hemming, Kell, and Schimmelpfennig 2003): (1) an overly expansionary fiscal stance, leading to a lending and/or consumption boom; (2) concerns about sustainability that may be sparked by revelations of contingent liabilities or by doubts about a government's commitment to fiscal adjustment; and (3) the debt maturity and currency structure, which can be critical to the perception of government liquidity and vulnerability to self-fulfilling crises.

The collapse of a fixed exchange rate regime can often be attributed to unsustainable fiscal policy (Krugman 1979). When the government runs a persistent primary fiscal deficit in the absence of fiscal reforms, the central bank must eventually finance this deficit with credit. This precipitates a continuous reduction in international reserves, until at some point a speculative attack happens, and the fixed exchange rate regime collapses. The importance of the structure of public debt as a source of vulnerability to crises is quite evident from emerging market experience. Hemming, Kell, and Schimmelpfennig (2003) present robust evidence that a few fiscal variables in emerging market economies are correlated with crises and with pressure in the foreign exchange market. When external public debt is high relative to tax revenue and exports, the public finances are vulnerable to a fall in the exchange rate, which increases debt-service costs without having a large positive effect on growth. 
Policymakers today are faced with the challenge to reduce deficits and debt levels in a way that ensures stability but is sufficiently supportive of short-term economic growth, employment, and equity. In this regard, the choice of the appropriate speed of fiscal adjustment has to weigh the costs (that is, adverse short-term effects on growth) against the benefits of a faster adjustment (a reduction in sovereign risk). Countries that have lost access to financial markets often have little choice but to front-load fiscal consolidation. For economies with access to markets, however, a number of country-specific factors are likely to shape the choice of the speed of adjustment. A large and protracted fiscal consolidation is likely to exacerbate income inequality. Adjustments should be carefully designed to limit their negative social effects and improve their durability (Bastagli, Coady, and Gupta 2012).

Emerging market economies are developing their local debt markets to lower currency and maturity mismatches and hence reduce exposure to exchange rate and world interest rate movements. They used to be highly exposed to interest rate and foreign exchange risk, because much of the foreign borrowing came in the form of short-term foreign-denominated debt. The growth of local currency debt markets over the past decade has lessened these currency mismatches and has also raised the duration of public debt. Further development of local currency bond markets, possibly in conjunction with macroprudential measures to discourage excessive reliance on short-term external debt, can help extend the gains of the past decade.

\section{Sovereign-Bank Nexus}

The interlinkages between the financial system and the public sector can arise from exposures of domestic financial institutions to public debt. Large holdings of government bonds (encouraged by prudential regulations that treat sovereign bonds as effectively zero-risk assets) make banks vulnerable to sovereign default, because adverse developments in the government's balance sheet can jeopardize the solvency of the banking system. Systemic banking sector problems that do not result from exposures to the sovereign but that could potentially impose large fiscal costs can also give rise to concerns about government solvency and precipitate a fiscal crisis. Also, the undermining of trust in the financial system is likely to occur at a time when the government's ability to backstop a deposit guarantee system is questioned, increasing the probability of a bank run.

Recently, the euro area debt crisis was a powerful reminder that the sustainability of public debt and the solvency of the financial sector are intertwined. ${ }^{23}$ Commercial banks tend to be among the largest purchasers of domestic public debt in many countries, and hence any write-downs on that debt immediately affect banks' solvency. Even in the absence of such explicit write-downs, a sudden

\footnotetext{
${ }^{23}$ For a historical analysis see Reinhart and Rogoff (2011).
} 
spike in yields on public debt can lead to a recalibration of sovereign risk, impairing the capital position of banks. For instance, Greek banks have faced large losses on their asset side because of the haircuts on Greek public debt that they have had to incur. Such effects can also reach across borders, as highlighted for example by the Cypriot banking crisis, which partly originated in the exposure of Cypriot banks to Greek debt, amounting to more than a quarter of Cypriot GDP (IMF 2011).

Many emerging market economies are highly dependent on the domestic banking sector for both corporate and sovereign funding. Such bank-centric systems are particularly prone to amplification effects between public debt sustainability and financial sector vulnerability. Capital losses from sovereign exposures can often lead banks to scale back their lending activities in order to keep their capital from falling below minimum prudential levels. In countries where firms are almost entirely dependent on bank loans for their financing needs, financial sector stress can quickly translate into a credit crunch and thereby lead to an economic slowdown. This in turn lowers tax revenues, further eroding the sustainability of public debt (IMF 2012a).

At times of sovereign and financial sector strain, the interlinkages between governments and banks often deepen (Mody and Sandri 2012). As governments find it difficult to tap foreign capital markets, they may pressure domestic banks into holding more sovereign debt. Banks, in turn, may willingly comply, as this increased dependence of the sovereign on their loans can imply a greater inclination to provide bailouts if and when needed (Acharya and Rajan 2013). The deepening nexus between the sovereign and the domestic financial sector can provide temporary relief and lower public debt yields during times of stress. But it also makes for a potentially hazardous combination as the solvency of the government and the financial sector become inextricably linked (IMF 2012b).

\section{Fiscal Dominance and Coordination of Fiscal and Monetary Policy}

Fiscal dominance implies that monetary policy becomes subservient to fiscal considerations. Indeed, high fiscal deficits and public debt can accentuate the links between monetary policy, fiscal policy, and debt management, raising the specter of fiscal dominance (Bank for International Settlements 2012). In such circumstances, the credibility of monetary policy's ability to keep inflation under control can be compromised. ${ }^{24}$ This can happen when the central bank is

\footnotetext{
${ }^{24}$ Examining Brazil during 2002-03, Blanchard (2004) argues the standard proposition that "a central-bank-engineered increase in real interest rates makes domestic government debt more attractive and leads to a real appreciation" may not hold if the country is highly indebted and rising real interest rates increase the probability of default. This is more likely the higher the initial debt level, the higher proportion of debt denominated in foreign currencies, and the higher the price of risk. Inflation targeting in such a situation can have perverse consequences: raising real interest rates in response to an expected increase in inflation could lead to a real depreciation.
} 
explicitly a part of the government or when the central bank is independent on paper but continues to be tacitly controlled by the Ministry of Finance. When coupled with large and persistent fiscal deficits, fiscal dominance can force the government to "print money" to close its financing gap, essentially implementing through inflation, a tax on the public's holding of money. Once high inflation expectations are formed, and the monetary authority loses the trust of the public, inflation cycles can prove difficult to break. India provides an example (Box 2.7). Therefore, achieving monetary policy objectives requires financial prudence and the availability of fiscal room that can be used during economic emergencies. Frontier economies would do well to have reasonable fiscal and foreign exchange buffers and maintain strict control on direct central bank lending to the government (Jácome and others 2012).

Monetary and fiscal policy coordination is important for achieving macroeconomic stability, which in turn promotes economic growth and financial sector development. The central bank needs a credible commitment to maintaining price stability. Therefore, monetary policy reacts to fiscal policy because of its impact on demand and inflation. The government needs a credible commitment to achieving fiscal objectives that are sustainable in the long term. However, in preparing its budget, the government takes into account the implications of fiscal measures on overall demand and, therefore, on monetary policy. The global financial crisis experience revealed the limits of monetary policy, especially when constrained by the zero-interest-rate bound, and showed the importance of monetary and fiscal policy working in tandem rather than placing the burden of shoring up demand to maintain economic growth on one policy or the other (Blanchard, Dell'Ariccia, and Mauro 2010; Akerlof and others 2014).

\section{CONCLUSION}

The recent history of emerging market economies provides a number of lessons for frontier economies. On the search for an appropriate nominal anchor, perhaps the central message is that the choice of one has implications far beyond just the conduct of monetary policy. A monetary policy framework cannot be seen in isolation, but needs to be considered as part of a broader strategy for development and reform.

Over the last three decades of the 20th century, most emerging market economies chose various forms of fixed and pegged exchange rates. Such pegs provided a clear anchor that was easy to communicate and generally helped reduce inflation. But emerging market experience shows that exchange rate "fixity" also allowed imbalances to build up if the pegs were not properly designed and/or supported by appropriate fiscal and structural policies. Persistent inflation differentials relative to partner countries eroded competitiveness, and short-term capital inflows led to currency and maturity mismatches in the financial system. Countries that use pegs need to be vigilant 


\section{BOX 2.7 Fiscal Dominance in India}

Although the degree of monetization has decreased considerably as a result of institutional reforms over the past two decades, high fiscal deficits still severely constrain the efficacy of monetary policy in India.

In the 1980s, the central and state governments had average deficits of about 6.7 and 2.8 percent of GDP, respectively. The fiscal deterioration placed a heavy burden on monetary policy as treasury bills issued to finance the fiscal deficits were automatically monetized. As a result, the Reserve Bank's net credit to the government expanded rapidly in the 1980s, and led to a sharp increase in the central bank's net domestic assets. Monetary pressures were felt as a result, despite a sharp decline in net foreign assets. After the two oil price shocks, inflation moderated until 1985-86, but returned as large fiscal expansions could not be countered by monetary contractions. The Reserve Bank raised the cash reserve ratio and the statutory liquidity ratio and used selective credit controls to maintain orderly conditions in the debt market. Credit budgeting in India was not very successful in the face of heavy fiscal dominance. It ended up generating financial repression that kept real interest rates low and discouraged savings. As a result, investments and supply capacity were constrained while inflation shot up.

India gradually reduced financial repression during 1992-2003. Several steps were taken to advance market-based financing of government deficits, including the development of money market instruments, the auctioning of Treasury bills, a reduction in statutory preemption through the cash reserve ratio and statutory liquidity ratio, and partial deregulation of interest rates. The period was marked by a distinct lowering of fiscal deficits until 1996-97. The credit compression of 1995-96 led to a sharper economic slowdown than envisaged. Monetary policy was able to ensure a substantial decline in inflation, but at a hefty cost to the real economy.

From 2003-04 to 2007-08, India introduced significant reforms to foster fiscal and monetary prudence. In the financial sector, the Reserve Bank moved from direct instruments to indirect instruments of monetary control. Simultaneously, fiscal reforms were undertaken at an unprecedented pace with the enactment of the Fiscal Responsibility and Budget Management Act of 2003. It unleashed a regime of fiscal rules to restrain discretionary spending. Under the law, annual targets were set for the phased reduction in key deficit indicators.

Fiscal and monetary policies were coordinated in responding to the global financial crisis (especially after the Lehman failure), but the exit from these policy responses was less harmonious. The unprecedented fiscal slippage amounted to 2.5 percent of GDP in fiscal year 2008-09 and the sudden large extra market borrowing in the last quarter resulted in the 10-year benchmark yield shooting up to 7 percent from 5 percent between December 2008 and March 2009. This happened despite the Reserve Bank's huge open market purchases to contain the increase in interest rates. The exit from stimulus turned out to be far more difficult than its provision, and the widening of the fiscal deficit increased the pressure to monetize the debt.

Source: Reserve Bank of India (2013).

and take appropriate measures to limit the buildup of macroeconomic and financial imbalances.

In recent years, emerging market economies have increasingly moved away from fixed exchange rate regimes toward a variety of inflation-targeting

\section{CInternational Monetary Fund. Not for Redistribution}


frameworks that allow for greater variation in exchange rates. Frontier markets that plan to adopt such monetary frameworks will require some institutional preparation, including central bank independence from the Ministry of Finance. In addition, information, knowledge, and analytical capacity will be required to understand the monetary policy transmission mechanism and effectively implement such a framework. Also, most emerging market economies that adopted inflation targeting have done so in a "flexible" manner. They often continue to manage exchange rate variability within certain bounds and have fashioned a number of macroprudential instruments to supplement the monetary policy toolkit for dealing with capital flows and financial stability concerns.

Financial and institutional development has promoted domestic saving and investment, increased public access to financial services, made it easier to implement monetary and fiscal policies, and contributed to increasing resilience to external shocks. But recent crises in emerging markets have shown that the path of financial liberalization can be hazardous. And as discussed, a gradual, phased, and pragmatic approach in which first relatively simple instruments and relatively safe and stable cross-border capital flows are allowed should be favored. Policymakers need to be aware of the market failures, the information and regulatory gaps, the divergence between private and social returns, and the limits of regulatory and enforcement systems in their countries. The benefits of international financial integration seem to show up only in countries that have crossed some minimum thresholds of good governance and financial development.

The recent experience of developed and developing economies alike has shown that a solvent state and a reasonably sound fiscal position are crucial to supplying basic public goods, providing a safety net for the poor, managing aggregate demand over the business cycle, backstopping the financial system, and dealing with economic and financial emergencies. The importance of fiscal policies and their long-term sustainability are hard to overemphasize. Even the independence of the central bank is predicated on a lack of fiscal dominance, since governments that cannot fund their operations through revenues and market borrowing are forced to use financial repression and the printing press, compromising the ability of policymakers to control inflation and develop the financial system. Fiscal challenges stem from small and narrow tax bases, weak tax administration systems, and vulnerabilities associated with sovereign debt denominated in foreign currencies. Frontier economies will have to chip away at these hurdles so that fiscal policy supports growth, employment, and equity.

The lessons of recent experience are clear: robust and steady economic growth is the key to keeping public debt ratios in a comfortable range; fiscal and political institutions play an important role in promoting fiscal sustainability and in creating the room required for stabilization needs; fiscal rules can be useful for maintaining discipline, but they are not a substitute for political will and sensible implementation in extreme circumstances; raising domestic savings and developing domestic bond markets can help reduce foreign currency mismatch in private and sovereign balance sheets; fiscal risks are often underestimated, compounded by

\section{(C) International Monetary Fund. Not for Redistribution}


the nexus between the government and the banks; and the realization of contingent liabilities can rapidly lead to unsustainable public debt dynamics.

Governance and supply-side factors in frontier economies, especially basic infrastructure and an increasingly educated workforce, will be crucial to exploiting growth opportunities as they arise and improving productivity and income per capita. The path of structural change and accompanying policy reform will have to be managed prudently. As institutions and markets evolve, the complex interactions between economic and financial policies and the real economy can be difficult to decipher and predict, especially with countries becoming more open to trade and capital flows. Frontier economies will have to tread this path carefully, and the macro-financial frameworks they adopt will need to contain the risks and vulnerabilities on the way.

\section{REFERENCES}

Acemoglu, Daron, Simon Johnson, and James A. Robinson. 2005. "The Rise of Europe: Atlantic Trade, Institutional Change and Economic Growth.” American Economic Review 95 (3): 546-79.

Acemoglu, Daron, and James A. Robinson. 2012. Why Nations Fail: The Origins of Power. Prosperity, and Poverty. New York: Crown.

Acharya, Viral V. 2013. "The Dodd-Frank Act and Basel III: Intentions, Unintended Consequences, and Lessons for Emerging Markets." In New Paradigms for Financial Regulation: Emerging Market Perspectives, edited by Masahiro Kawai and Eswar S. Prasad. Washington: Brookings Institution Press.

Acharya, Viral V., and Raghuram Rajan. 2013. "Sovereign Debt, Government Myopia, and the Financial Sector." Review of Financial Studies 26: 1526-560.

Agur, Itai, and Sunil Sharma. 2014. "Rules, Discretion and Macro-Prudential Policy." In Institutional Structure of Financial Regulation: Theories and International Experiences, edited by Robin Hui Huang and Dirk Schoenmaker. New York: Routledge.

Ahmad, Shaghil, and Andrei Zlate. 2013. "Capital Flows to Emerging Market Economies: A Brave New World?” International Finance Discussion Papers 1081, Federal Reserve Board, Washington.

Aizenman, Joshua, Michael Hutchison, and Ilan Noy. 2008. "Inflation Targeting and Real Exchange Rates in Emerging Markets.” NBER Working Paper 14561, National Bureau of Economic Research, Cambridge, Massachusetts.

Akerlof, George, Olivier Blanchard, David Romer, and Joseph Stiglitz, eds. 2014. What Have We Learned? Macroeconomic Policy after the Crisis. Cambridge, Massachusetts: MIT Press.

Alfaro, Laura, Sebnem Kalemli-Ozcan, and Selin Sayek. 2009. "FDI, Productivity and Financial Development." The World Economy 32 (1): 111-35.

Allen, Franklin, Elena Carletti, Jun Qian, and Patricio Valenzuela. 2013. "Does Finance Accelerate or Retard Growth? Theory and Evidence." Working Paper 4, Global Citizen Foundation, Geneva.

Amato, Jeffery D., and Stefan Gerlach. 2002. "Inflation Targeting in Emerging Market and Transition Economies: Lessons after a Decade." European Economic Review 46: 781-90.

Balakrishnan, Ravi, Chad Steinberg, and Murtaza H. Syed. 2013. "The Elusive Quest for Inclusive Growth: Growth, Poverty, and Inequality in Asia." IMF Working Paper 13/152, International Monetary Fund, Washington.

Bank for International Settlements. 2012. "Fiscal Policy, Public Debt and Monetary Policy in Emerging Market Economies.” BIS Paper 67, October, Bank for International Settlements, Basel. 
Bastagli, Francesca, David Coady, and Sanjeev Gupta. 2012. "Income Inequality and Fiscal Policy." IMF Staff Discussion Note 12/08, International Monetary Fund, Washington.

Basu, Kaushik. 2011. Beyond the Invisible Hand: Groundwork for a New Economics. Princeton, New Jersey and Oxford: Princeton University Press.

Batini, Nicoletta, Peter Breuer, Kalpana Kochhar, and Scott Roger. 2006. "Inflation Targeting and the IMF." IMF Policy Paper, International Monetary Fund, Washington.

Bernanke, Ben S., Thomas Laubach, Frederic S. Mishkin, and Adam S. Posen. 1999. Inflation Targeting: Lessons from the International Experience. Princeton, New Jersey: Princeton University Press.

Bernanke, Ben S., and Michael Woodford, eds. 2005. The Inflation Targeting Debate, NBER Studies in Business Cycles 32. Chicago: University of Chicago Press.

Bhagwati, Jagdish. 1998. "The Capital Myth." Foreign Affairs 77: 7-12.

Bhagwati, Jagdish, and Arvind Panagariya. 2013. Why Growth Matters: How Economic Growth in India Reduced Poverty and the Lessons for Other Developing Countries. New York: Public Affairs.

Blanchard, Olivier. 2004. "Fiscal Domination and Inflation Targeting: Lessons from Brazil." NBER Working Paper 10389, National Bureau of Economic Research, Cambridge, Massachusetts.

Blanchard, Olivier, Giovanni Dell'Ariccia, and Paolo Mauro. 2010. "Rethinking Macroeconomic Policy." IMF Staff Position Note 10/13, International Monetary Fund, Washington.

Blejer, Mario I., Alain Ize, Alfredo M. Leone, and Sergio Werlang, eds. 2000. Inflation Targeting in Practice, Washington: International Monetary Fund.

Borio, Claudio, and Ilhyock Shim. 2009. "What Can Macro-Prudential Policy Do to Support Monetary Policy?” BIS Working Paper 242, Bank for International Settlements, Basel.

Borio, Claudio, and Haibin Zhu. 2012. "Capital Regulation, Risk-Taking and Monetary Policy: A Missing Link in the Transmission Mechanism?” Journal of Financial Stability 8: 236-251.

Brondolo, John, Carlos Silvani, Eric Le Borgne, and Frank Bosch. 2008. "Tax Administration Reform and Fiscal Adjustment: The Case of Indonesia." IMF Working Paper 08/129, International Monetary Fund, Washington.

Brunnermeier, Markus K., Andrew D. Crockett, Charles A. E. Goodhart, Avinash D. Persaud, and Hyun S. Shin. 2009. The Fundamental Principles of Financial Regulation, Geneva Reports on the World Economy 11. International Center for Monetary and Banking Studies, Geneva, and Centre for Economic Policy Research, London.

Bruno, Valentina, and Hyun Song Shin. 2014. "Assessing Macroprudential Policies: Case of Korea." Scandinavian Journal of Economics, 116 (1): 128-157.

Bunda, Irina, Subir Lall, and Sunil Sharma. 2011. "The Impact of the Global Financial Crisis on Emerging and Newly Industrialized Asia." In The Impact of the Global Financial Crisis on Emerging Financial Markets: Contemporary Studies in Economic and Financial Analysis, edited by Jonathan A. Batten and Peter G. Szilagyi. London: Emerald Group.

Calvo, Guillermo A., and Frederic S. Mishkin. 2003. "The Mirage of Exchange Rate Regimes for Emerging Market Countries." Journal of Economic Perspectives 17 (4) (Fall): 99-118.

Calvo, Guillermo, and Carmen Reinhart. 2002. "Fear of Floating." Quarterly Journal of Economics, 117 (2): 379-408.

Cangiano, Marco, Teresa Curristine, and Michel Lazare, eds., 2013. Public Financial Management and Its Emerging Architecture. Washington: International Monetary Fund.

Cebotari, Aliona, Jeffrey M. Davis, Lusine Lusinyan, Amine Mati, Paolo Mauro, Murray Petrie, and Ricardo Velloso. 2009. "Fiscal Risks: Sources, Disclosure, and Management." IMF Discussion Paper 09/01.

Chami, Ralph, Connel Fullenkamp, and Sunil Sharma. 2010. "A Framework for Financial Market Development." Journal of Economic Policy Reform 13 (2): 107-135.

Choi, Woon Gyu, Sunil Sharma, and Maria Strömqvist. 2007. "Capital Flows, Financial Integration and International Reserve Holdings: The Recent Experience of Emerging Markets and Advanced Economies." IMF Staff Papers 56 (3): 516-540. 
Committee on International Economic Policy and Reform. 2012. Banks and Cross-Border Capital Flows: Policy Challenges and Regulatory Responses. Washington: Brookings Institution.

Coulibaly, Brahimina. 2012. "Monetary Policy in Emerging Market Economies: What Lessons from the Global Financial Crisis?” International Finance Discussion Papers 1042, Federal Reserve Board, Washington.

de Carvalho Filho, Irineu. 2011. "28 Months Later: How Inflation Targeters Outperformed Their Peers in the Great Recession." B.E. Journal of Macroeconomics 11 (1): 1-46.

De Gregorio, José. 2009. "Exchange Rates, Real Adjustment and Monetary Policy." Economic Policy Papers, Central Bank of Chile, Santiago.

Debelle, Guy. 2001. "The Case for Inflation Targeting in East Asian Countries." In Future Directions for Monetary Policies in East Asia, edited by David Gruen and John Simon, 65-87, Reserve Bank of Australia.

Debrun, Xavier, Laurent Moulin, Alessandro Turrini, Joaquim Ayuso-i-Casals, and Manmohan S. Kumar. 2008. "Tied to the Mast? National Fiscal Rules in the European Union." Economic Policy (April): 299-362.

Dell'Ariccia Giovanni, Julian di Giovanni, André Faria, Ayhan Kose, Paolo Mauro, Jonathan Ostry, Martin Schindler, and Marco Terrones. 2008. Reaping the Benefits of Financial Globalization. IMF Occasional Paper 264. Washington: International Monetary Fund.

Demirgüç-Kunt, Asli, and Leora Klapper. 2013. "Measuring Financial Inclusion: Explaining Variation in Use of Financial Services across and within Countries." Brookings Papers on Economic Activity 1: 279-340, Brookings Institution, Washington.

Dreze, Jean, and Amartya Sen. 2013. An Uncertain Glory: India and Its Contradictions. Princeton, NJ: Princeton University Press.

Edison, Hali J., Ross Levine, and Torsten Sløk. 2002. "International Financial Integration and Economic Growth." Journal of International Money and Finance 21: 749-776.

Edwards, Sebastian. 2011. "Exchange Rates in Emerging Countries: Eleven Empirical Regularities from Latin America and East Asia." NBER Working Paper 17074, National Bureau of Economic Research, Cambridge, Massachusetts.

Eichengreen, Barry. 2004. "Monetary and Exchange Rate Policy in Korea: Assessments and Policy Issues." CEPR Discussion Paper 4676, Center for Economic Policy Research, London.

Eichengreen, Barry, and Poonam Gupta. 2014. "Tapering Talk: The Impact of Expectations of Reduced Federal Reserve Security Purchases on Emerging Markets." World Bank Policy Research Working Paper 6754, World Bank, Washington.

Eichengreen, Barry, and Ricardo Hausmann. 1999. "Exchange Rates and Financial Fragility." In New Challenges for Monetary Policy. Kansas City, Missouri: Federal Reserve Bank of Kansas City.

Eichengreen, Barry, Paul Masson, Miguel Savastano, and Sunil Sharma. 1999. "Transition Strategies and Nominal Anchors on the Road to Greater Exchange Rate Flexibility." Essays in International Finance, 213, April, Princeton University, Princeton, New Jersey.

Fatás, Antonio, and Ilian Mihov. 2013. "Policy Volatility, Institutions, and Economic Growth." Review of Economics and Statistics 95 (2): 362-76.

Filardo, Andrew. 2012. "Ensuring Price Stability in Post-Crisis Asia: Lessons from the Recovery." BIS Working Paper, 378 (April), Bank for International Settlements, Basel.

Filardo, Andrew, and Hans Genberg. 2010. "Monetary Policy Strategies in the Asia-Pacific Region: What Way Forward?” ADB Institute Working Paper, 195, Asian Development Bank Institute, Tokyo.

Filardo, Andrew, Guonan Ma, and Dubravko Mihaljek. 2011. "Exchange Rates and Monetary Policy Frameworks in Emerging Market Economies." BIS Papers, 57, Bank for International Settlements, Basel.

Financial Stability Board. 2011. Scoping the Issues, 11 April, Basel. 2012. Global Shadow Banking Monitoring Report, 18 November, Basel. 2013. Global Shadow Banking Monitoring Report, 14 November, Basel. 
Fischer, Stanley. 1998. "Capital Account Liberalization and the Role of the IMF." In Should the IMF Pursue Capital-Account Convertibility? Essays in International Finance, 207, 1-10. Princeton, New Jersey: Princeton University.

_ 2001. "Exchange Rate Regimes: Is the Bipolar View Correct?" Journal of Economic Perspectives 15 (2): 3-24.

Fraga, Arminio, Ilan Goldfajn, and Andre Minella. 2003. "Inflation Targeting in Emerging Market Economies." NBER Working Paper 10019, National Bureau of Economic Research, Cambridge, Massachusetts.

Frankel, Jeffrey. 2003. "Experience of and Lessons from Exchange Rate Regimes in Emerging Economies." In Monetary and Financial Cooperation in East Asia. Manila: Asian Development Bank; London: Macmillan Press.

. 2005. "Contractionary Currency Crises in Developing Countries." IMF Staff Papers 52 (2): 149-192.

Frankel, Jeffrey A. Carlos A. Végh, and Guillermo Vuletin. 2013. "On Graduation from Fiscal Procyclicality." Journal of Development Economics 100 (1): 32-47.

Freedman, Charles, and Inci Ötker-Robe. 2010. "Important Elements for Inflation Targeting for Emerging Economies.” IMF Working Paper 10/113, International Monetary Fund, Washington.

Fukuyama, Francis. 2004. State Building: Governance and World Order in the 21st Century. Ithaca, New York: Cornell University Press.

Gill, Indermit, and Homi Kharas. 2007. An East Asian Renaissance. Washington: World Bank.

Gokarn, Subir. 2013. "Strengthening Macroeconomic Frameworks: The Indian Experience." In New Paradigms for Financial Regulation: Emerging Market Perspectives, edited by Mashiro Kawai and Eswar Prasad. Washington: Brookings Institution Press.

Goswami, Mangal, and Sunil Sharma. 2011. "The Development of Local Debt Markets in Asia." In Asian Perspectives on Financial Sector Reforms and Regulation, edited by Mashiro Kawai and Eswar Prasad. Washington: Brookings Institution Press.

Greene, Joshua E. 2012. Public Finance: An International Perspective. Singapore: World Scientific.

Grenville, Stephen. 2008. "Central Banks and Capital Flows.” ADBI Discussion Paper \#87, Asian Development Bank Institute, Tokyo.

Hahm, Joon-Ho, Frederic S. Mishkin, Hyun Song Shin, and Kwanho Shin. 2012. "Macroprudential Policies in Open Emerging Economies," NBER Working Paper 17780, Cambridge, Massachusetts: National Bureau of Economic Research.

Hammond, Gill, Ravi Kanbur, and Eswar Prasad, eds. 2009. Monetary Policy Frameworks for Emerging Markets. Cheltenham, United Kingdom: Edward Elgar.

Havro, Goril, and Javier Santiso. 2008. "To Benefit from Plenty: Lessons from Chile and Norway." OECD Development Centre Policy Brief 37, Organisation for Economic Co-operation and Development, Paris.

Heenan, Geoffrey, Marcel Peter, and Scott Roger. 2006. "Implementing Inflation Targeting: Institutional Arrangements, Target Design, and Communications.” IMF Working Paper 06/278, International Monetary Fund, Washington.

Hemming, Richard, Michael Kell, and Axel Schimmelpfennig. 2003. Fiscal Vulnerability and Financial Crises in Emerging Market Economies, IMF Occasional Paper 218, International Monetary Fund, Washington.

Hoffmaister, Alexander W. 1999. "Inflation Targeting in Korea: An Empirical Exploration." IMF Working Paper 99/7, International Monetary Fund, Washington.

Hutchison, Michael, Rajeshwari Sengupta, and Nirvikar Singh. 2010. "India’s Trilemma: Financial Liberalization, Exchange Rates and Monetary Policy." Unpublished, UC Santa Cruz, September.

Im, Fernando G., and David Rosenblatt. 2013. "Middle-Income Traps: A Conceptual and Empirical Survey." Policy Research Working Paper 6594, World Bank, Washington.

Inoue, Takeshi, Yuki Toyoshima, and Shigeyuki Hamori. 2012. "Inflation Targeting in Korea, Indonesia, Thailand and the Philippines: The Impact on Business Cycle Synchronization

\section{(C) International Monetary Fund. Not for Redistribution}


between Each Country and the World." IDE Discussion Paper 328, Chiba, Institute of Developing Economies, Japan.

International Monetary Fund (IMF). 1998. International Capital Markets: Developments, Prospects, and Key Policy Issues. September, World Economic and Financial Surveys. Washington.

—. 2002. "Assessing Sustainability," Washington.

2003a. "Lessons from the Crisis in Argentina," Washington.

2003b. World Economic Outlook: Public Debt in Emerging Markets, September, World Economic and Financial Surveys. Washington.

. 2010. "Indonesia: Report on the Observance of Standards and Codes (ROSC) Fiscal Transparency Module-Update.” IMF Country Report 10/342, Washington.

—_. 2011. "Revenue Mobilization in Developing Countries." IMF Policy Paper, Washington.

. 2012a. "Philippines: Technical Assistance Report on Road Map for a Pro-Growth and Equitable Tax." IMF Country Report 12/60, Washington.

. 2012b. "The Liberalization and Management of Capital Flows: An Institutional View."

IMF Policy Paper, Washington.

2012c. "The Interaction of Monetary and Macroprudential Policies," Washington.

2012d. "Liberalizing Capital Flows and Managing Outflows," Washington.

2013a (April). Regional Economic Outlook: Asia and Pacific-Shifting Risks, New Foundations for Growth. World Economic and Financial Surveys, Washington.

. 2013b. "Energy Subsidy Reform: Lessons and Implications." IMF Policy Paper, Washington.

. 2013c. "Case Studies on Energy Subsidy Reform: Lessons and Implications," Washington.

- 2013d (April). Fiscal Monitor: Fiscal Adjustment in an Uncertain World. World Economic and Financial Surveys, Washington.

—. 2013e. "Key Aspects of Macroprudential Policy," Washington.

_. 2014. "Fiscal Policy and Income Inequality," Washington.

Irwin, Timothy C. 2012. "Accounting Devices and Fiscal Illusions." IMF Staff Discussion Note 12/02, International Monetary Fund, Washington.

Ishii, Shogo, Karl Habermeier, Jorge Ivan Canales-Kriljenko, Bernard Laurens, John Leimone, and Judit Vadasz. 2002. Capital Account Liberalization and Financial Sector Stability. IMF Occasional Paper 211. Washington: International Monetary Fund.

Jácome, Luis I., Marcela Matamoros-Indorf, Mrinalini Sharma, and Simon Townsend. 2012. "Central Bank Credit to the Government: What Can We Learn from International Practices." IMF Working Paper 12/16, International Monetary Fund, Washington.

Jeanne, Olivier, Arvind Subramanian, and John Williamson. 2012. Who Needs to Open the Capital Account. Washington: Peterson Institute for International Economics.

Kaminsky, Graciela L., Carmen M. Reinhart, and Carlos A. Végh. 2005. "When It Rains, It Pours: Procyclical Capital Flows and Macroeconomic Policies." In NBER Macroeconomics Annual 2004, 19, edited by Mark Gertler and Kenneth Rogoff. Cambridge, Massachusetts: National Bureau of Economic Research.

Kawai, Masahiro, and Eswar S. Prasad, eds. 2011. Financial Market Regulation and Reforms in Emerging Markets. Washington: Brookings Institution.

Kim, Choongsoo. 2013. "Harmonious Operation of Macroprudential and Monetary Policies, and Challenges." Bank of Korea, Seoul, April 8.

Kim, Soyoung, and Yung Chul Park. 2006, "Inflation Targeting in Korea: A Model of Success?" In Monetary Policy in Asia: Approaches in Implementation. Edited by Hans Genberg and Eli Remolona. BIS Papers 31. Basel: Bank for International Settlements.

Kose, M. Ayhan, and Eswar S. Prasad. 2010. Emerging Markets: Resilience and Growth amid Global Turmoil. Washington: Brookings Institution.

Kose, M. Ayhan, Eswar Prasad, and Ashley D. Taylor. 2011. "Thresholds in the Process of International Financial Integration." Journal of International Money and Finance 30 (1): $147-79$.

\section{CInternational Monetary Fund. Not for Redistribution}


Kose, M. Ayhan, Eswar S. Prasad, Kenneth Rogoff, and Shang-Jin Wei. 2009a. "Financial Globalization: A Reappraisal." IMF Staff Papers 56 (1): 8-62. 2009b. "Financial Globalization and Economic Policies." Brookings Global Economy \& Development Working Paper 34, April, Brookings Institution, Washington.

Krugman, Paul. 1979. "A Model of Balance of Payments Crises." Journal of Money, Credit and Banking 11: 311-25.

Lane, Philip R. 2003. "Business Cycles and Macroeconomic Policy in Emerging Market Economies." International Finance 6 (1): 89-108.

Lane, Philip R., and Gian Maria Milesi-Ferretti. 2007. "The External Wealth of Nations Mark II: Revised and Extended Estimates of Foreign Assets and Liabilities, 1970-2004." Journal of International Economics 73 (2): 223-250.

Lejot, Paul, Douglas Arner, and Lotte Schou-Zibell. 2008. "Securitization in East Asia." ADB Working Paper Series on Regional Economic Integration 12, Asian Development Bank, Manila.

Lim, Cheng Hoon, Alejo Costa, Torsten Wezel, Akira Otani, Francesco Columba, Mustafa Sayid, Xiaoyong Wu, and Piyabha Kongsamut. 2011. "Macroprudential Policy: What Instruments and How to Use Them? Lessons from Country Experiences." IMF Working Paper 11/238, International Monetary Fund, Washington.

Lindgren, Carl-Johan, Tomás J.T. Balinno, Charles Enoch, Anne-Marie Gulde, Marc Quintyn, and Leslie Teo. 1999. Financial Sector Crisis and Restructuring Lessons from Asia. IMF Occasional Paper 188. Washington: International Monetary Fund.

Liu, Linlin. 2011. "The Impact of Foreign Direct Investment on China: An Empirical Analysis Based on the Chinese Real Estate Sector." Research Papers 89, Southern Illinois University, Carbondale.

Masson, Paul R., Miguel A. Savastano, and Sunil Sharma. 1997. "The Scope for Inflation Targeting in Developing Countries.” IMF Working Paper 97/130, International Monetary Fund, Washington.

_ 1998. "Can Inflation Targeting Be a Framework for Monetary Policy in Developing Countries?” Finance \& Development 35 (1).

McGettigan, Donal, Kenji Moriyama, J. Noah Ndela Ntsama, Francois Painchaud, Haonan $\mathrm{Qu}$, and Chad Steinberg. 2013, "Monetary Policy in Emerging Markets: Taming the Cycle." IMF Working Paper 13/96, International Monetary Fund, Washington.

McGettigan, Donal, Kenji Moriyama, and Chad Steinberg. 2013. "Monetary Policy Cyclicality in Emerging Markets." IMF Research Bulletin 14 (3).

Menon, Ravi. 2014. "Getting in All the Cracks or Targeting the Cracks? Securing Financial Stability in the Post-Crisis Era." Remarks at the Asian Monetary Policy Forum (AMPF), Singapore, May 24.

Mishkin, Frederic. 2000. "Inflation Targeting in Emerging Market Countries." American Economic Review 90 (2): 105-109.

Mishra, Prachi, and Peter Montiel. 2012, "How Effective Is Monetary Transmission in LowIncome Countries? A Survey of the Empirical Evidence." IMF Working Paper 12/143, International Monetary Fund, Washington.

Mody, Ashoka, and Damiano Sandri. 2012. "The Eurozone Crisis: How Banks and Sovereigns Came To Be Joined at the Hip.” Economic Policy 27 (April): 199-230.

Mohan, Rakesh. 2012. Growth with Financial Stability: Central Banking in an Emerging Market. New Delhi: Oxford University Press.

Mohan, Rakesh, and Muneesh Kapur. 2009. "Managing the Impossible Trinity: Volatile Capital Flows and Indian Monetary Policy.” Working Paper 401 (November), Stanford Center for International Development.

Mohanty, M. S., and Philip Turner. 2008. "Monetary Policy Transmission in Emerging Market Economies: What Is New?” BIS Papers 35, 1-59, Bank for International Settlements, Basel.

- 2010, "Banks and Financial Intermediation in Emerging Asia: Reforms and New Risks.” BIS Working Papers 313 (June), Bank for International Settlements, Basel. 
Montiel, Peter. 2005. "Public Debt Management and Macroeconomic Stability: An Overview." World Bank Economic Review 20 (2): 259-81.

. 2013. “Capital Flows: Issues and Policies.” IDB Working Paper 411, Inter-American Development Bank, Washington.

Mussa, Michael, Paul Masson, Alexander Swoboda, Esteban Jadresic, Paolo Mauro, and Andy Berg. 2000. Exchange Rate Regimes in an Increasingly Integrated World Economy. IMF Occasional Paper 193. Washington: International Monetary Fund.

Nier, Erlend W., Jacek Osiński, Luis I. Jácome, and Pamela Madrid. 2011. "Towards Effective Macroprudential Policy Frameworks: An Assessment of Stylized Institutional Models.” IMF Working Paper 11/250, International Monetary Fund, Washington.

Nijathaworn, Bandid, and Piti Disyatat. 2009. "The Pursuit of Monetary and Financial Stability in Emerging Market Economies." In Monetary Policy Frameworks for Emerging Markets, edited by Gill Hammond, Ravi Kanbur, and Eswar Prasad. London: Edward Elgar.

Nunn, Nathan, and Daniel Trefler. 2014. "Domestic Institutions as a Source of Comparative Advantage." In Handbook of International Economics, edited by Gita Gopinath, Elhanan Helpman, and Kenneth Rogoff. Amsterdam: North Holland.

Obstfeld, Maurice. 2014. "Trilemmas and Tradeoffs: Living with Financial Globalization." Paper presented at the Asian Monetary Policy Forum, Singapore, June.

Obstfeld, Maurice, and Kenneth Rogoff. 1995. “The Mirage of Fixed Exchange Rates.” Journal of Economic Perspectives 9 (4): 73-96.

Ostry, Jonathan D., Andrew Berg, and C. Tsangarides. 2014. "Redistribution, Inequality, and Growth.” IMF Staff Discussion Note 14/02, International Monetary Fund, Washington.

Ostry, Jonathan D., Atish R. Ghosh, and Marcos Chamon. 2012. "Two Targets, Two Instruments: Monetary and Exchange Rate Policies in Emerging Markets." IMF Staff Discussion Note 12/01, International Monetary Fund, Washington.

Prasad, Eswar and Raghuram Rajan. 2008. "A Pragmatic Approach to Capital Account Liberalization." Journal of Economic Perspectives 22 (3): 149-72.

Rajan, Raghuram. 2013. "The Five Pillars of Reserve Bank of India’s Financial Sector Policies.” Remarks at the Annual Bankers' Conference (BANCON), Mumbai, November 15.

2014. "Competitive Monetary Easing: Is It Yesterday Once More?" Remarks at the Brookings Institution, Washington, April 10.

Ree, Jack Joo K., Kyoungsoo Yoon, and Hail Park. 2012. "FX Funding Risks and Exchange Rate Volatility: Korea's Case.” IMF Working Paper 12/268, International Monetary Fund, Washington.

Reichlin, Lucrezia, and Richard Baldwin. 2013. Is Inflation Targeting Dead? Central Banking after the Crisis. London: Centre for Economic Policy Research.

Reinhart, Carmen M., and Kenneth S. Rogoff. 2011. "From Financial Crash to Debt Crisis." American Economic Review 101(5): 1676-1706.

Reserve Bank of India. 2013. "Fiscal-Monetary Co-ordination in India." Report on Currency and Finance, March 4.

Reserve Bank of India. 2014. Report of the Expert Committee to Revise and Strengthen the Monetary Policy Framework.

Rey, Hélène. 2013. "Dilemma not Trilemma: The Global Financial Cycle and Monetary Policy Independence." Paper presented at the Jackson Hole Symposium, Wyoming, August.

Rodrik, Dani. 2013. "The Past, Present, and Future of Economic Growth." Working Paper 1, Global Citizen Foundation, Geneva.

Rogoff, Kenneth S., Assim M. Husain, Ashoka Mody, Robin Brooks, and Nienke Oomes. 2003. "Evolution and Performance of Exchange Rate Regimes." IMF Working Paper 03/243, International Monetary Fund, Washington.

Schaechter, Andrea, Tidiane Kinda, Nina Budina, and Anke Weber. 2012. "Fiscal Rules in Response to the Crisis: Toward the "Next-Generation" Rules. A New Dataset." IMF Working Paper 12/187, International Monetary Fund, Washington.

\section{(C) International Monetary Fund. Not for Redistribution}


Schaechter, Andrea, Mark R. Stone, and Mark Zelmer. 2000. Adopting Inflation Targeting: Practical Issues for Emerging Market Countries. IMF Occasional Paper 202. Washington: International Monetary Fund.

Singh, Sukudhew. 2009. "The Nexus between Monetary and Financial Stability: The Experience of Selected Asian Economies." In Monetary Policy Frameworks for Emerging Markets, edited by Gill Hammond, Ravi Kanbur, and Eswar Prasad. London: Edward Elgar.

— 2011. "Monetary Policy Challenges for Emerging Markets in a Globalized Environment." In Asian Perspectives on Financial Sector Reforms and Regulation, edited by Masahiro Kawai and Eswar S. Prasad. Washington: Brookings Institution Press.

Stiglitz, Joseph E. 2001. "Principles of Financial Regulation: A Dynamic Portfolio Approach." World Bank Research Observer 16 (1): 1-18.

Stone, Mark R. 2003. "Inflation Targeting Lite.” IMF Working Paper 03/12, International Monetary Fund, Washington.

Stone, Mark, Scott Roger, Seiichi Shimizu, Anna Nordstrom, Turgut Kişinbay, and Jorge Restrepo. 2009. The Role of the Exchange Rate in Inflation Targeting Emerging Economies. IMF Occasional Paper 267. Washington: International Monetary Fund.

Summers, Lawrence H. 2000. "International Financial Crises: Causes, Prevention, and Cures." American Economic Review, Papers and Proceedings 90 (2): 1-16.

Svensson, Lars E. O. 2010. "Inflation Targeting." In Handbook of Monetary Economics, edited by Benjamin M. Friedman and Michael Woodford. First edition, Chapter 22, 1237-302. Amsterdam: Elsevier.

Tanzi, Vito. 2011. Government versus Markets: The Changing Economic Role of the State. New York: Cambridge University Press.

Végh, Carlos A., and Guillermo Vuletin. 2012. "Overcoming the Fear of Free Falling: Monetary Policy Graduation in Emerging Markets." NBER Working Paper 18175, National Bureau of Economic Research, Cambridge, Massachusetts.

White, William. 2006. "Procyclicality in the Financial System: Do We Need a New MacroFinancial Stabilization Framework?” BIS Working Paper 193, Bank for International Settlements, Basel.

Zeti Akhtar Aziz. 2013. "Greater Financial Integration and Financial Stability." Remarks at the SEACEN 30th Anniversary Conference, Kuala Lumpur, October 20. 


\section{Transforming Economies and Growth}

CInternational Monetary Fund. Not for Redistribution 
This page intentionally left blank

CInternational Monetary Fund. Not for Redistribution 


\section{Diversification, Growth, and Volatility}

\section{Chris Papageorgiou, Nikola Spatafora, and Ke Wang}

Limited diversification in exports and broader economic structure have long been underlying characteristics of many developing and, in particular, frontier economies. Yet some have shown a remarkable economic transformation, especially over the past two decades. In particular, it has been argued that emerging Asia, and more recently frontier Asia, has benefited significantly from diversification. This chapter examines this claim with a comprehensive look at the facts, employing newly developed data sets covering diversification in both external trade and domestic production.

The chapter focuses on two key questions. First, is diversification crucial to sustaining growth and reducing volatility? Put differently, does concentration in sectors with limited scope for productivity growth and quality upgrading, such as primary commodities, result in less broad-based and sustainable growth? And does lack of diversification increase exposure to adverse external shocks and macroeconomic instability?

Second, what precisely does diversification, in both external trade and the broader domestic economy, involve? How is it linked to broader structural transformation, including the process of quality upgrading? And which countries and regions have been more successful in promoting diversification?

This chapter is based on ongoing IMF work that aims to inform the policy debate by examining diversification patterns and the role of diversification in the macroeconomic performance of developing economies, using both cross-country data and case studies.

\section{HOW IS DIVERSIFICATION MEASURED?}

Measures of economic diversification need to look beyond trade to capture domestic sector diversification and the underlying dynamic process of structural transformation. Trade diversification and domestic diversification are in principle interlinked, the former reflecting diversification in the external sector, and the latter capturing diversification in the domestic production process across sectors. An underlying theme of this chapter is that focusing on the entire structure of production paints a more comprehensive and illuminating picture. Therefore, the two dimensions of diversification are evaluated simultaneously, filling a gap in the 
existing literature, which has treated them independently. In addition, the analysis focuses on "diversification spurts" - that is, rapid, sustained, and significant episodes of diversification.

Trade diversification can be achieved along several dimensions. First, diversification may occur across either products or trading partners. Second, product diversification may occur through the introduction of new product lines (extensive margin) or a more balanced mix of existing exports (intensive margin). Finally, product-quality upgrading represents a slightly different notion and is evidenced by higher prices for existing exports. Our main data source for trade is an updated version of the UN-NBER data set, which harmonizes COMTRADE bilateral trade flow data at the 4-digit Standard International Trade Classification (SITC, Rev. 1) level. ${ }^{1}$ However, while the existing literature typically focuses on the post1988 period, this chapter uses data extending back to 1962 . The extended time dimension turns out to be greatly helpful in examining relationships more comprehensively.

Analysis of domestic diversification in frontier economies required construction of a new IMF data set. This chapter examines diversification in sectoral output and the sectoral allocation of labor using data from existing and new sources. Existing data sets include measures of value added for 28 manufacturing sectors during 1985-2010 (from United Nations Industrial Development Organization 2011, 3-digit ISIC classification) and labor employment shares in nine economy-wide sectors during 1969-2008 (from International Labour Organization 2011, 1-digit classification). It is well known, however, that both data sets are quite limited in their coverage of frontier countries. For this reason, a new data set was constructed, covering 12 economy-wide sectors during 2000-10, using country data compiled from IMF desk inputs (see below for further discussion).

Appendix 3.1 provides greater detail on the diversification indices and quality measures employed in this chapter. Briefly, diversification is measured using the Theil index, which has the advantage of being decomposable into diversification along the extensive and intensive margins. Lower values of the index indicate greater diversification. Quality measures are based on individual products' unit values (that is, trade prices), but with important adjustments for differences in production costs, as well as for selection bias in the composition of international trade. Appendix 3.2 sets out a full list of the countries and regions analyzed.

\section{DIVERSIFICATION, GROWTH, AND VOLATILITY}

We start by examining the evidence on the links between diversification and growth. One result stands out: diversification patterns and growth are clearly related, although the relationship displays much heterogeneity. In particular, greater diversification is on average associated with faster subsequent output

\footnotetext{
${ }^{1}$ The data set combines importer- and exporter-reported data from COMTRADE to maximize comprehensiveness, while ensuring internal consistency, using the methodology of Asmundson (forthcoming).
} 

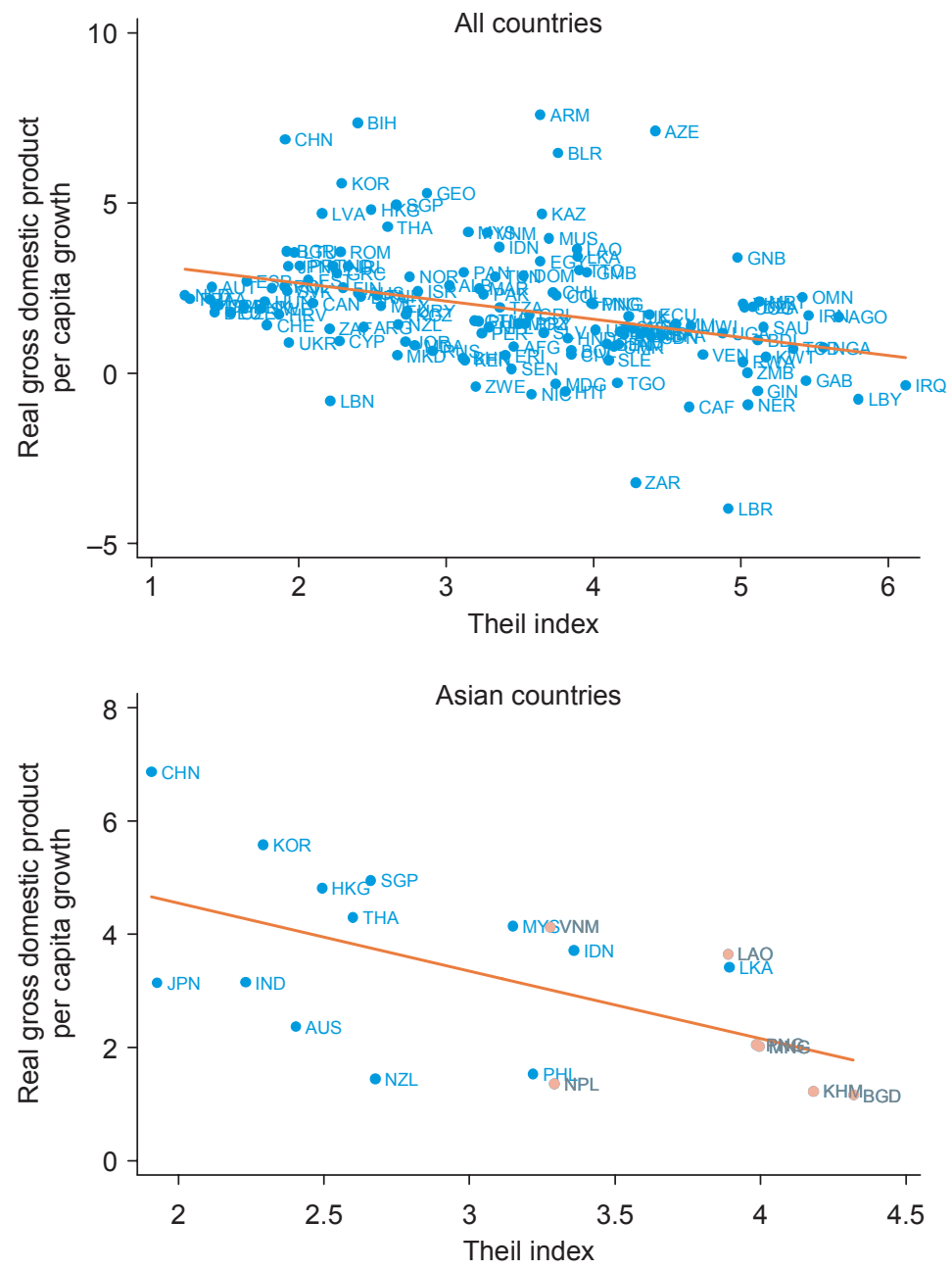

- Frontier Asia - Other Asia and Pacific countries

Figure 3.1 Growth and Diversification, 1962-2010

Sources: Penn World Table 7.0; UN Comtrade; and IMF staff calculations.

Note: For a list of the country abbreviations used in this figure, please consult the UN three-letter country codes; see http://unstats.un.org/unsd/methods/m49/m49alpha.htm.

growth (Figure 3.1). The relationship holds both for the sample as a whole and for Asian countries alone. Adopting a multivariate regression approach, output growth remains significantly associated with both initial diversification and initial product quality measures, even after controlling for a variety of standard growth determinants (Table 3.1). This conclusion is in line with the extensive literature, including Singer (1950); Sachs and Warner (1995) on the "natural-resource curse"; and Hausmann, Hwang, and Rodrik (2007) on the links between growth and product sophistication. 
TABLE 3.1

\begin{tabular}{|c|c|c|c|c|c|c|c|c|c|c|}
\hline Growth Regressions & Diversif & tion and & ality Indic & & & & & & & \\
\hline \multirow[b]{3}{*}{ Variables } & \multicolumn{10}{|c|}{ Growth Regression, Generalized Least Squares Fixed Effects } \\
\hline & \multicolumn{4}{|c|}{ All Countries } & \multicolumn{2}{|c|}{ East Asia } & \multicolumn{2}{|c|}{ South Asia } & \multicolumn{2}{|c|}{ Frontier Asia } \\
\hline & (1) & (2) & (3) & (4) & $(5)$ & (6) & (7) & $(8)$ & (7) & (8) \\
\hline Lagged GDP & $\begin{array}{c}-5.363^{* * *} \\
(0.439)\end{array}$ & $\begin{array}{c}-6.027^{* * *} \\
(0.464)\end{array}$ & $\begin{array}{c}-5.898^{* * * *} \\
(0.454)\end{array}$ & $\begin{array}{c}-5.897^{* * *} \\
(0.471)\end{array}$ & $\begin{array}{c}-5.604^{* * *} \\
(1.697)\end{array}$ & $\begin{array}{c}-4.886^{* * *} \\
(1.551)\end{array}$ & $\begin{array}{l}-3.882 \\
(3.488)\end{array}$ & $\begin{array}{c}-7.313^{* * *} \\
(2.173)\end{array}$ & $\begin{array}{c}-5.858^{* *} \\
(2.421)\end{array}$ & $\begin{array}{c}-7.848^{* * *} \\
(2.326)\end{array}$ \\
\hline Education & $\begin{array}{c}0.124^{* * *} \\
(0.023)\end{array}$ & $\begin{array}{c}0.139 * * * \\
(0.023)\end{array}$ & $\begin{array}{c}0.146^{* * *} \\
(0.023)\end{array}$ & $\begin{array}{c}0.137^{* * *} \\
(0.023)\end{array}$ & $\begin{array}{c}0.236^{* *} \\
(0.101)\end{array}$ & $\begin{array}{c}0.217^{* *} \\
(0.100)\end{array}$ & $\begin{array}{c}0.203 \\
(0.125)\end{array}$ & $\begin{array}{l}0.208^{*} \\
(0.112)\end{array}$ & $\begin{array}{c}0.124 \\
(0.123)\end{array}$ & $\begin{array}{c}0.151 \\
(0.114)\end{array}$ \\
\hline Investment & $\begin{array}{c}3.599 * * * \\
(0.433)\end{array}$ & $\begin{array}{c}3.523^{* * *} \\
(0.429)\end{array}$ & $\begin{array}{c}3.513^{* * *} \\
(0.429)\end{array}$ & $\begin{array}{c}3.374 * * * \\
(0.436)\end{array}$ & $\begin{array}{c}4.520^{* * *} \\
(1.428)\end{array}$ & $\begin{array}{c}4.324^{* * *} \\
(1.408)\end{array}$ & $\begin{array}{l}4.046^{* *} \\
(1.626)\end{array}$ & $\begin{array}{c}4.436 * * * \\
(1.401)\end{array}$ & $\begin{array}{c}2.513 \\
(1.682)\end{array}$ & $\begin{array}{c}3.867^{* * *} \\
(1.268)\end{array}$ \\
\hline Population growth & $\begin{array}{l}-0.053 \\
(0.229)\end{array}$ & $\begin{array}{l}-0.194 \\
(0.227)\end{array}$ & $\begin{array}{l}-0.238 \\
(0.228)\end{array}$ & $\begin{array}{l}-0.118 \\
(0.227)\end{array}$ & $\begin{array}{c}0.869 \\
(0.738)\end{array}$ & $\begin{array}{c}0.670 \\
(0.736)\end{array}$ & $\begin{array}{l}-1.346 \\
(2.749)\end{array}$ & $\begin{array}{l}-1.759 \\
(2.248)\end{array}$ & $\begin{array}{c}1.191 \\
(0.726)\end{array}$ & $\begin{array}{c}0.917 \\
(0.745)\end{array}$ \\
\hline Diversification index & $\begin{array}{c}-0.608^{* *} \\
(0.279)\end{array}$ & & & & & & & & & \\
\hline Quality index & & $\begin{array}{l}8.761^{* * *} \\
(2.124)\end{array}$ & & & $\begin{array}{l}13.660^{*} \\
(6.878)\end{array}$ & & $\begin{array}{c}-8.572 \\
(15.365)\end{array}$ & & $\begin{array}{l}19.601 * \\
(10.970)\end{array}$ & \\
\hline Quality index, agriculture & & & $\begin{array}{c}9.687^{* * * *} \\
(2.348)\end{array}$ & & & $\begin{array}{c}21.036^{* *} \\
(8.361)\end{array}$ & & & & $\begin{array}{c}19.555^{* *} \\
(9.405)\end{array}$ \\
\hline Quality index, manufacture & & & & $\begin{array}{c}7.646^{* * *} \\
(2.485)\end{array}$ & & & & $\begin{array}{c}48.638^{* *} \\
(18.846)\end{array}$ & & \\
\hline Constant & $\begin{array}{c}35.550 * * * \\
(3.720)\end{array}$ & $\begin{array}{c}31.748^{* * *} \\
(3.534)\end{array}$ & $\begin{array}{c}29.948^{* * *} \\
(3.614)\end{array}$ & $\begin{array}{c}31.842^{* * *} \\
(3.570)\end{array}$ & $\begin{array}{c}16.662^{*} \\
(9.267)\end{array}$ & $\begin{array}{c}6.508 \\
(9.840)\end{array}$ & $\begin{array}{c}22.728 \\
(19.191)\end{array}$ & $\begin{array}{c}0.110 \\
(18.537)\end{array}$ & $\begin{array}{c}19.448 \\
(17.004)\end{array}$ & $\begin{array}{c}30.538^{* *} \\
(14.384)\end{array}$ \\
\hline Observations & 790 & 789 & 789 & 789 & 75 & 75 & 46 & 46 & 50 & 50 \\
\hline$R$-squared & 0.234 & 0.250 & 0.250 & 0.241 & 0.291 & 0.317 & 0.295 & 0.402 & 0.441 & 0.456 \\
\hline Number of countries & 113 & 113 & 113 & 113 & 10 & 10 & 6 & 6 & 7 & 7 \\
\hline
\end{tabular}

Source: IMF staff calculations.

Notes: For Asian country groups, coefficients on diversification index are not significant.

Standard errors in parentheses

${ }^{* * *} p<0.01,{ }^{* *} p<0.05$ ， $p<0.1$ 


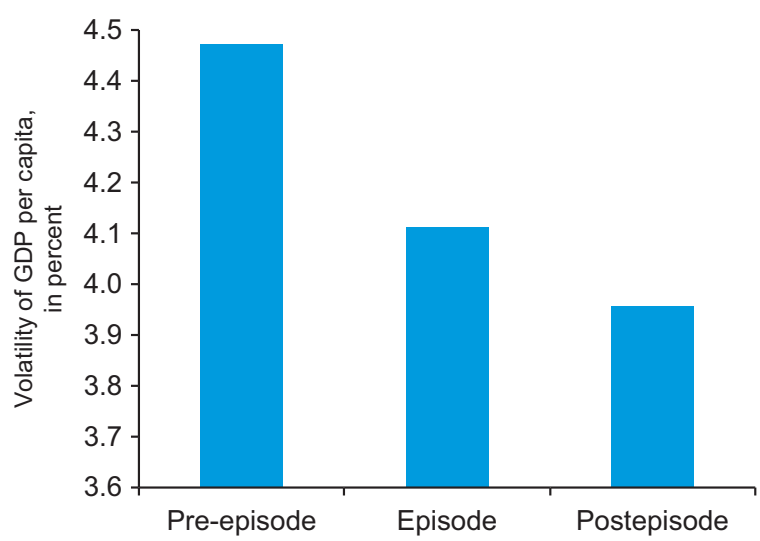

Figure 3.2 Volatility and Export Diversification

Sources: UN Comtrade; and IMF staff calculations.

Note: Episode indicates diversification spurts. The procedure for identifying spurts is based on Berg, Ostry, and Zettelmeyer (2012).

In a similar vein, diversification spurts (defined as in Papageorgiou and Spatafora 2012) are associated with sharp subsequent growth accelerations (defined analogously to diversification spurts). This is especially true for nonfragile frontier economies. Conversely, growth accelerations are associated with subsequent increases in diversification among nonfragile frontier economies.

Next, we examine the links between diversification and volatility. Does diversification serve as a buffer against external shocks? In a related question, are diversification spurts associated with increased macroeconomic stability? The existing literature provides some evidence that countries with more diversified production structures tend to have lower volatility of output, consumption, and investment (Mobarak 2005, Moore and Walkes 2010). Further, product diversification can increase the resilience of frontier economies to external shocks (Koren and Tenreyro 2007).

A key channel is that diversification involves frontier economies shifting resources from sectors where prices are highly volatile and correlated, such as mining and agriculture, to less volatile and correlated sectors, such as manufacturing, resulting in greater stability. And, indeed, the data show clearly that output volatility diminishes after diversification spurts (Figure 3.2).

\section{PATTERNS OF DIVERSIFICATION}

Having established that diversification is indeed linked with macroeconomic performance, we now examine patterns of diversification in greater detail, with a focus on identifying which regions and countries have made greater progress in achieving diversification. Overall, higher income per capita and development are broadly associated with greater trade diversification (Figure 3.3), at least until an 


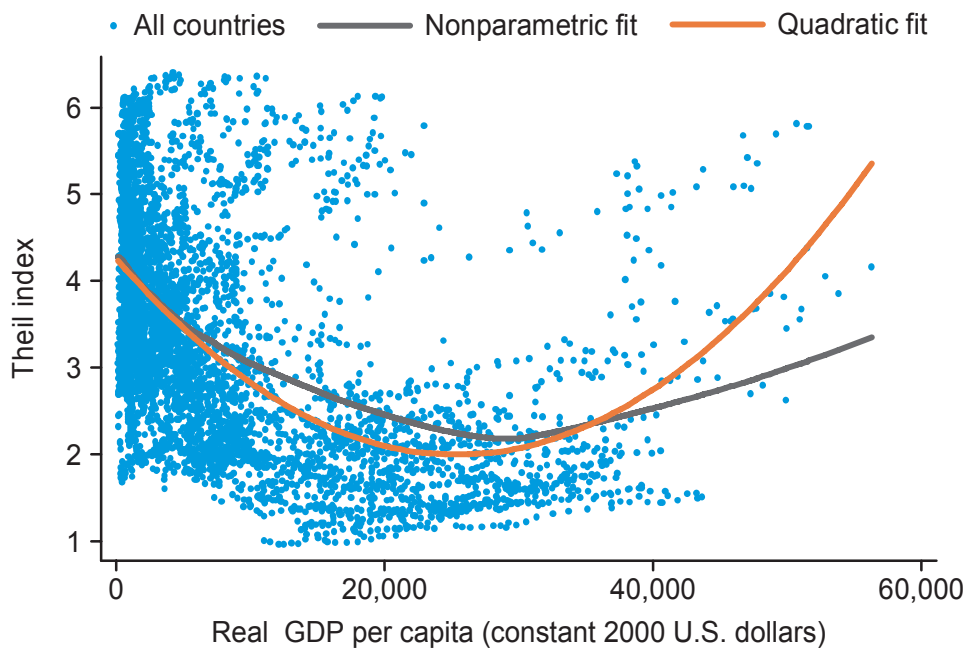

Figure 3.3 Export Diversification and Real GDP Per Capita

Sources: Penn World Table 7.0; UN Comtrade; and IMF staff calculations. Note: Each observation denotes one country-year combination.s

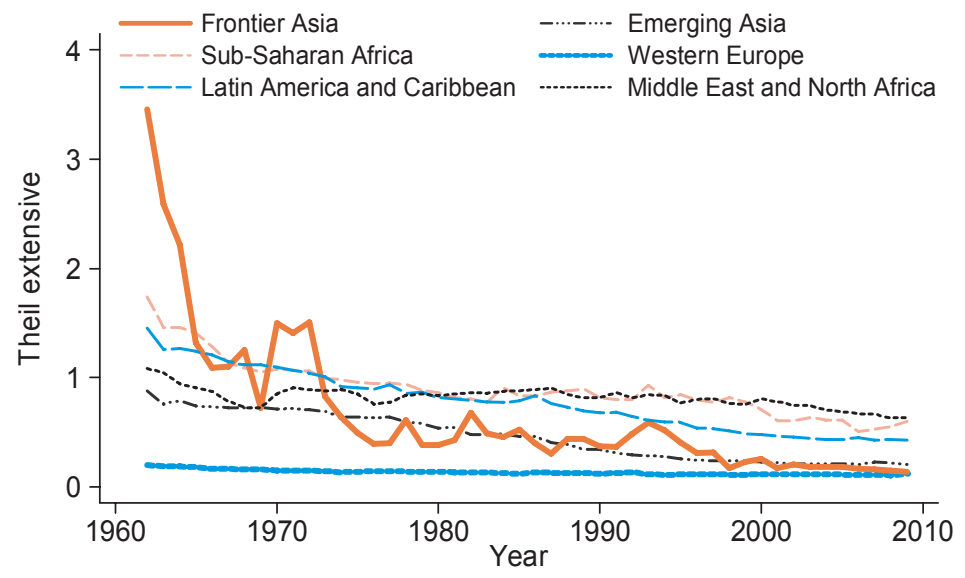

Figure 3.4 Export Diversification by Region, 1960-2010: Extensive Margin Sources: UN Comtrade; and IMF staff calculations.

economy reaches advanced-economy status (with GDP per capita of $\$ 25,000$ $\$ 30,000$; see also Cadot, Carrere, and Strauss-Kahn 2011). The relationship holds for the sample as a whole. It also holds between and within countries (that is, when the figure is restricted to show the pure cross-sectional or time-series variation); in the latter case, the data set's extended time dimension is critical to confirming the relationship.

At a regional level, western Europe is the most diversified. However, emerging and frontier Asia have been rapidly catching up (Figure 3.4). Asia in 


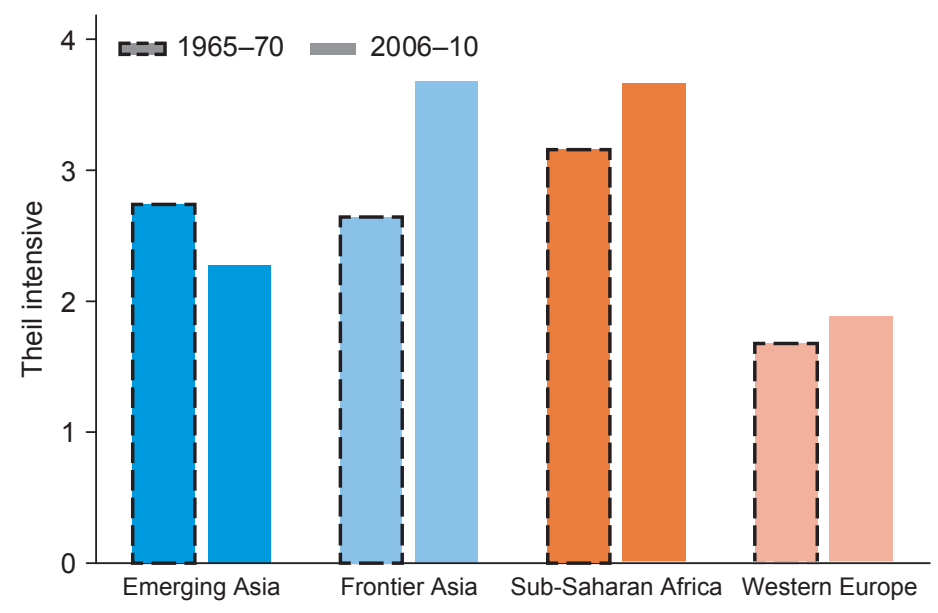

Figure 3.5 Export Diversification by Region and Period: Intensive Margin Sources: UN Comtrade; and IMF staff calculations.

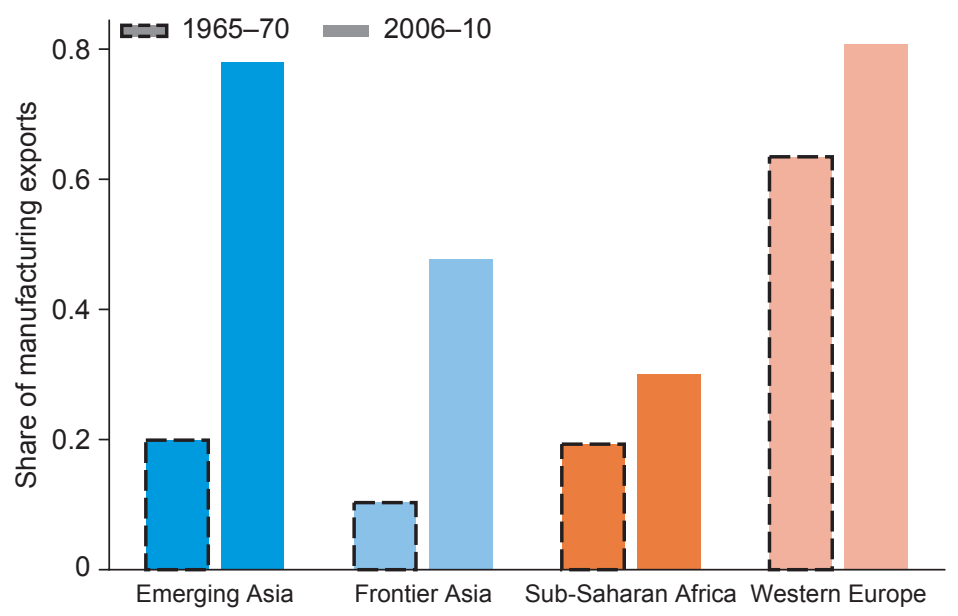

Figure 3.6 Manufacturing Exports Share, by Region and Period Sources: UN Comtrade; and IMF staff calculations.

general shows higher and more rapidly growing diversification than subSaharan Africa and the Middle East and North Africa, although progress slowed after 1995. Increases in diversification have largely occurred along the extensive margin - that is, through entry into completely new products, although there has also been progress along the intensive margin for emerging Asia (Figure 3.5). Also, changes in trade diversification over time have been paralleled by decreases in the relative importance of agricultural exports and increases in the relative importance of manufactured exports, especially for Asian countries (Figure 3.6). 


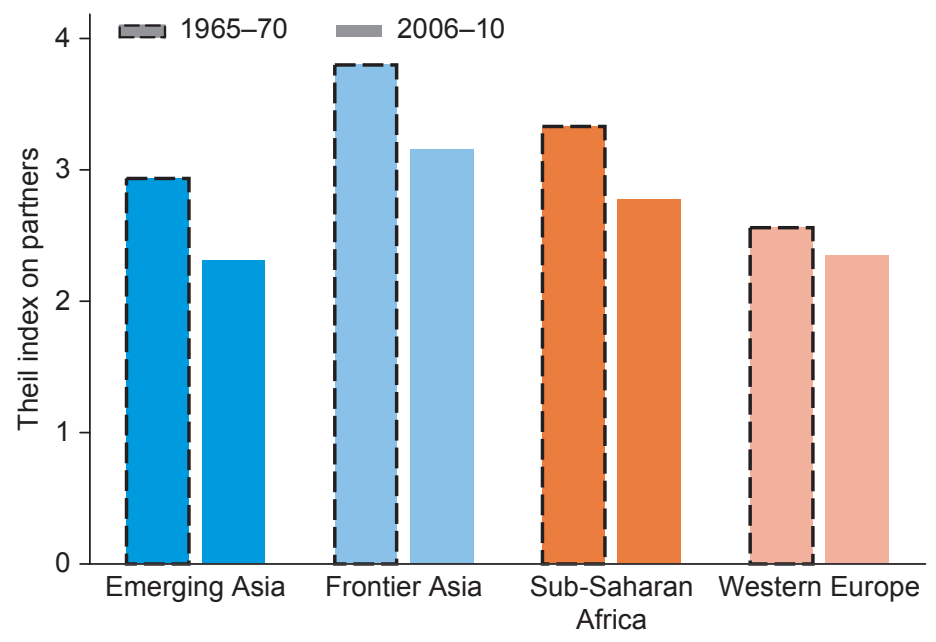

Figure 3.7 Trade Diversification across Partners over Time Sources: UN Comtrade; and IMF staff calculations.

Higher income levels are also associated with increasing diversification across trade partners — at least until advanced-economy status is reached. After 1995, Asia greatly diversified its trade across partners (Figure 3.7). Frontier economies in general, including in sub-Saharan Africa, also have made progress in diversifying their exports across partners. The trend is especially clear when considering the extensive margin, with a significant increase in exports to completely new partners. This is related to ongoing globalization and a clear shift in trade away from the European Union and toward Asia-China in particular (see also Samake and Yang 2011).

Next, the data also reveal that, within developing economies, greater income per capita is also associated with greater real-sector diversification-that is, diversification in the broader domestic economy. During the 2000s, across all developing economies and within frontier Asia, analysis of six key sectors shows that there was significant real diversification. In particular, the share of agriculture in output declined significantly. The gap was filled largely by nontradables such as construction, wholesale trade, and transportation, rather than by manufacturing (Figure 3.8). That said, there is significant cross-country variation, both in the magnitude of the resource shift out of agriculture and in the precise identity of the sectors that have expanded in its place.

\section{PATTERNS OF QUALITY UPGRADING}

Economic development is underpinned not just by new products and markets, but also by quality improvements to existing products. Producing higher-quality varieties, through more physical- and human-capital-intensive production 


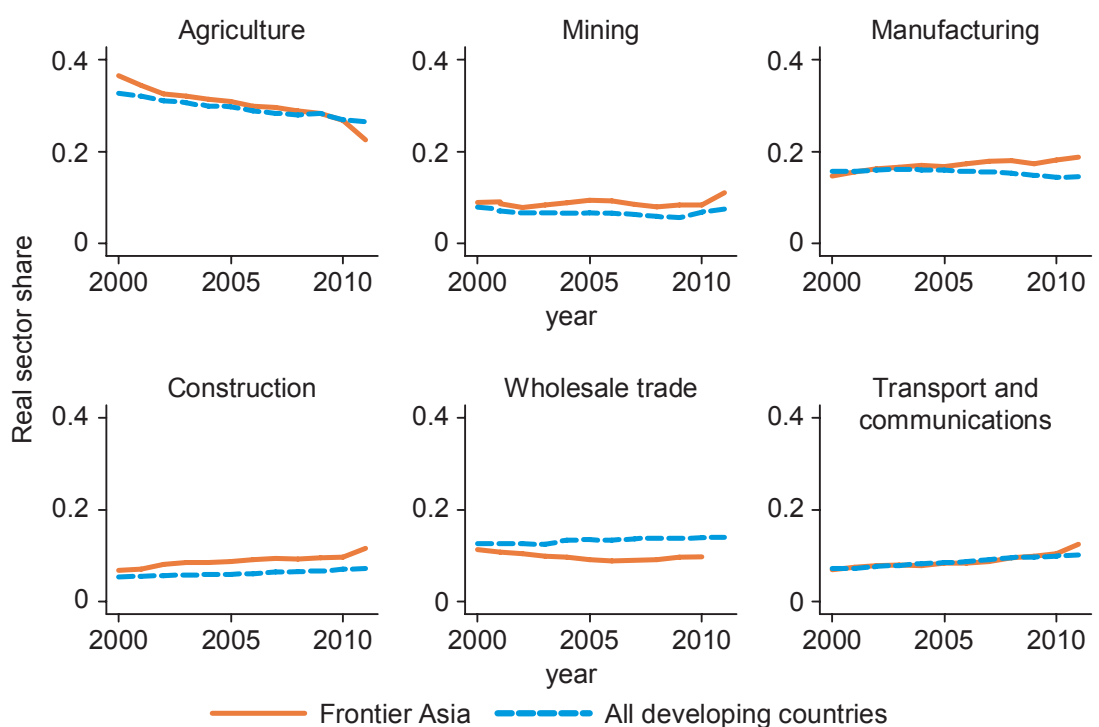

Figure 3.8 Real-Sector Share of Frontier Asia, 2000-10

Source: IMF staff calculations.

techniques, helps build on existing comparative advantages. It can boost countries' productivity and export revenues. ${ }^{2}$ Ongoing work is helping to develop a toolkit to answer key questions, including calculating an economy's export quality and how it has evolved over time, determining the current potential for quality upgrading, and analyzing whether diversification into new products is a prerequisite for further quality upgrading. One robust conclusion is that both emerging Asia and, more recently, frontier Asia have on average enjoyed remarkable success in quality upgrading. That said, significant cross-country variation remains.

Our quality measures are based on individual products' unit values (that is, trade prices). However, these unit values are adjusted to reflect differences in production costs, as well as selection bias in the composition of international trade. Quality estimates at the country level are then constructed as a geometric value-weighted mean of the quality estimates for individual products. For full details, see Appendix 3.1, as well as Henn, Papageorgiou, and Spatafora (2013). Among other benefits, these quality measures smooth much of the artificial volatility often observed in unit values.

The data suggest some clear patterns. Higher incomes per capita are associated with greater export quality at the country level. The relationship holds both across all goods (Figure 3.9) and (even more clearly) within manufacturing, which has

\footnotetext{
${ }^{2}$ See Schott (2004) for an early demonstration that product quality varies significantly and systematically across exporters.
} 


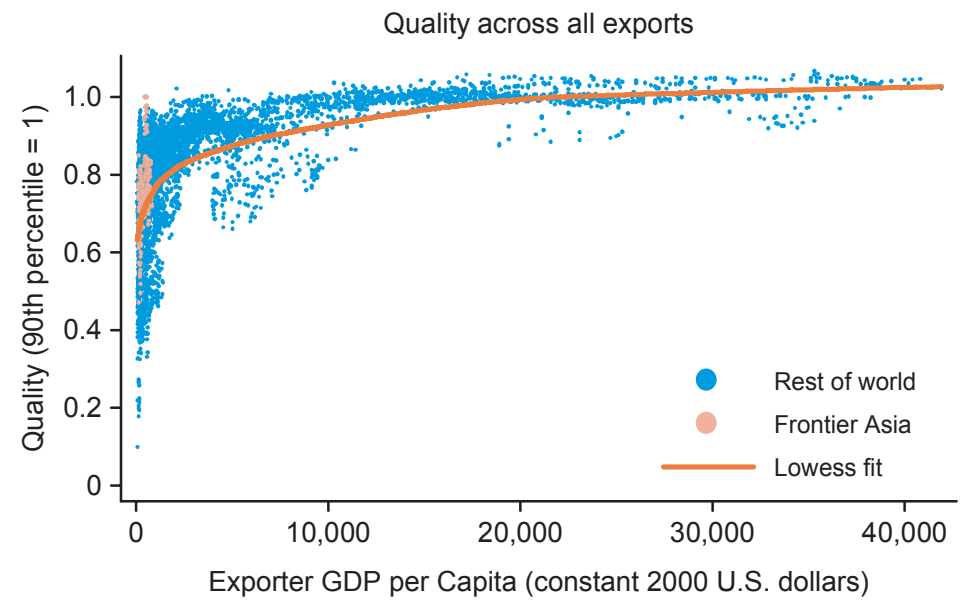

Figure 3.9 Quality Index and GDP per Capita in Frontier Asia, 1960-2010 Sources: Penn World Tables 7.0; UN Comtrade; and IMF staff calculations.

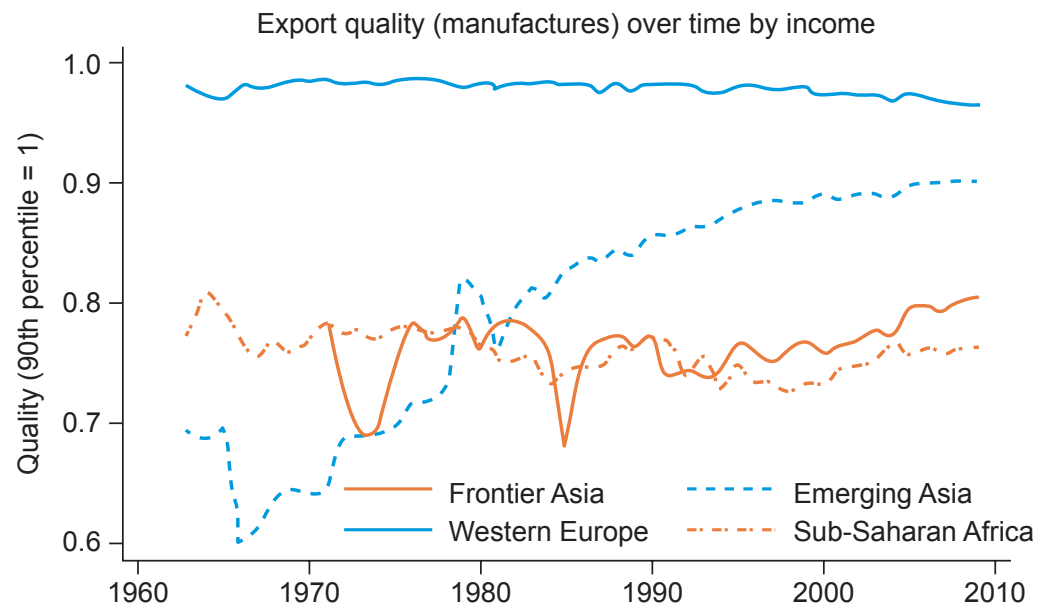

Figure 3.10 Manufacturing Quality Index by Region, 1960-2010 Sources: Penn World Tables 7.0; UN Comtrade; and IMF staff calculations.

greater scope for differentiation. Quality upgrading is particularly marked as countries evolve from frontier status into middle-income economies.

There is much heterogeneity in quality levels, even when controlling for income per capita. In particular, emerging Asia has enjoyed immense success in quality upgrading since 1970 (Figure 3.10), whereas frontier Asia only began the process in the early 2000s. Sub-Saharan Africa stands out as producing relatively low-quality goods. 

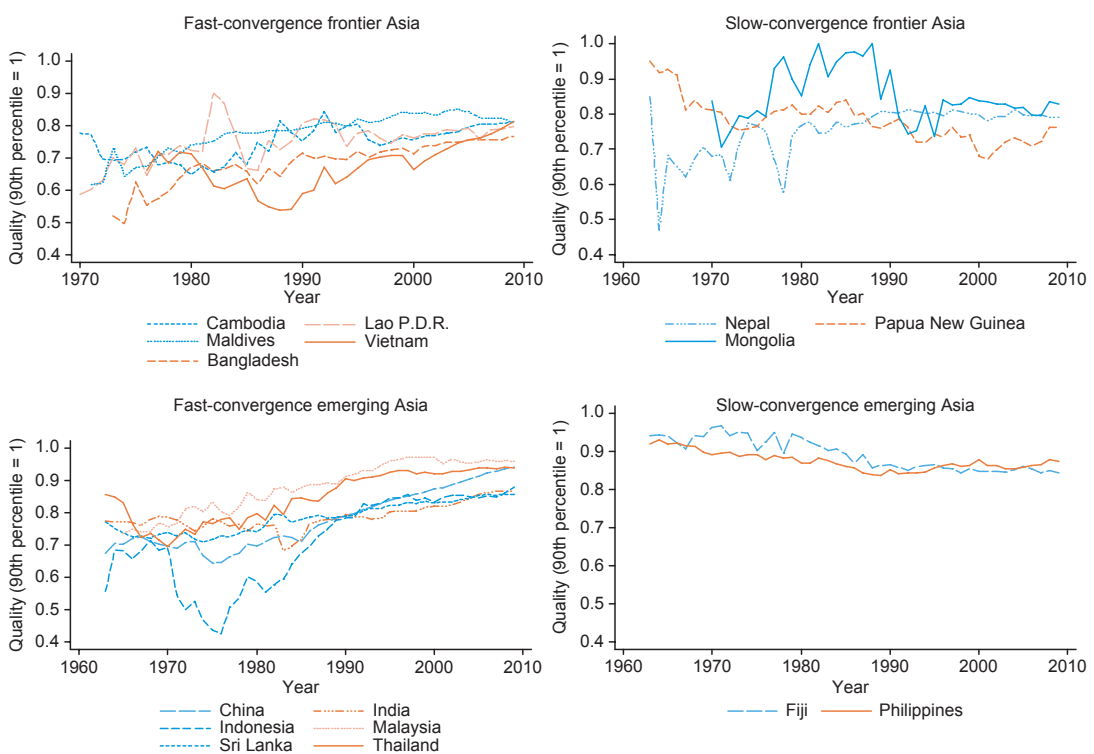

Figure 3.11 Quality Convergence of Asian Countries, 1960-2010

Sources: Penn World Tables 7.0; UN Comtrade; and IMF staff calculations.

Focusing on Asia, some countries have converged or are continuing to converge to the world frontier. In other cases, convergence seems to have slowed since the mid-1990s (Figure 3.11). Overall, improvements in export quality are associated with growth takeoffs. Hence, Japan converged to the world frontier in the 1970s; Korea's convergence occurred between the 1970s and the early 1990s; China started its takeoff in the late 1980s and has since been converging very rapidly; and Vietnam's convergence started in the 1990s. In Malaysia and Thailand, convergence was rapid but appears to have stalled before reaching the world frontier. India seems to be converging but only slowly. Likewise, Bangladesh's convergence is very slow, particularly given its large catch-up potential.

Crucially, developing economies' potential for quality upgrading does not appear to be limited by low demand for quality in their existing destination markets. Frontier economies do tend to serve markets that import lower-quality products (Figure 3.12). However, the differences are not substantial enough to act as a constraint on quality upgrading. Indeed, on average, the lower income the exporter, the greater the gap between its export quality and the average quality of its trade partners' imports. Likewise, in slow-converging countries, export quality is substantially lower than the average quality of their trade partners' imports. All this suggests that policy should focus on creating a domestic environment broadly conducive to quality upgrading; lowering barriers to entry into higher-quality export markets constitutes a less urgent priority. 
Export quality relative to destination markets (World frontier $=1$ )

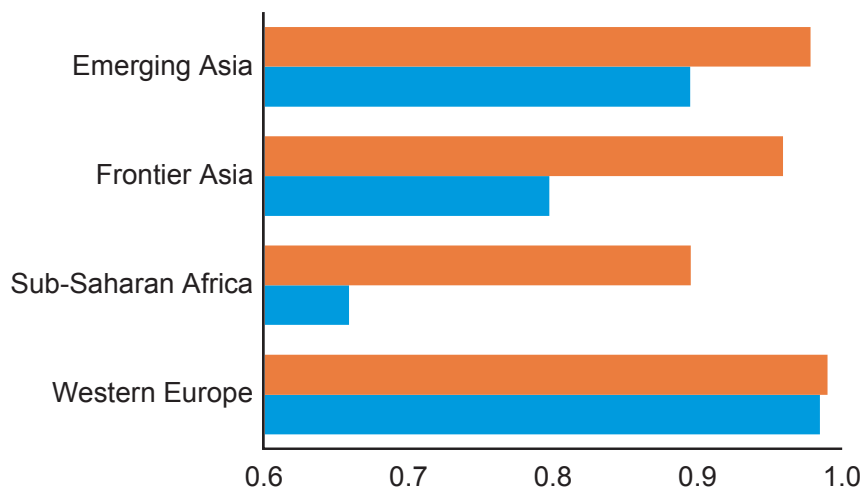

$\square$ Average quality demanded in destination countries n Quality exported

Figure 3.12 Export Quality by Region, 2009

Sources: Penn World Tables 7.0; UN Comtrade; and IMF staff calculations.

\section{COUNTRY CASE STUDIES}

To obtain robust policy conclusions, it is critical to complement the above crosscountry analysis of product diversification and quality upgrading with individual country case studies. To this end, Appendix 3.3 discusses the experience of Bangladesh in more detail, a frontier economy with income per capita well below $\$ 1,000$, and Vietnam, a country on the threshold of middle-income status. In addition, Pitt and others (forthcoming) analyze developments in Tanzania, another frontier economy; Angola, the second largest oil exporter in sub-Saharan Africa and a middle-income country still facing significant physical and human capital needs; and Malaysia, an emerging market whose income per capita has grown 20 -fold over the past 40 years.

Overall, these case studies provide some tentative evidence in favor of four main themes. First, analyzing the entire structure of production paints a more comprehensive and illuminating picture than focusing purely on external trade. Structural transformation may well be associated with significant diversification of domestic production, including nontradables. Examining this may shed light on the underlying mechanisms and barriers to further transformation.

Second, diversification and structural transformation are often underpinned by reforms and policy measures that are general in scope. Macroeconomic stabilization is a clear example. But even microeconomic measures are often broad based, focusing on improving the quantity and quality of infrastructure or essential business services or on setting up a welcoming environment for foreign investors. It remains an open issue to what extent industry-focused and narrowly targeted measures have historically helped underpin diversification efforts. 
Third, effective policy measures come in "waves" and aim at exploiting the evolving comparative advantages of the economy in changing external conditions. The types of reforms underpinning diversification and structural transformation in the early stages of development are different from those required later on and need to be adapted to the external environment the economy faces.

Finally, the frequency with which new products are introduced and the rate at which they grow can indicate potential policy-driven bottlenecks. Limited entry may indicate that barriers deter firms from exporting or experimenting. If survival rates are low, firms may face more obstacles than expected. If surviving firms cannot expand, they may have inadequate access to finance.

\section{CONCLUSION}

One key message from this chapter and related work is that economic development critically involves diversification and structural transformation-that is, the continued, dynamic reallocation of resources from less productive to more productive sectors and activities. This process involves not just external trade, but the broader economy. Success in this transformation will reduce volatility and accelerate growth.

However, there are major differences across regions and countries in the degree to which they have succeeded in diversifying and transforming their economies. Over an extended period, Asia has on average been particularly successful in diversifying its exports, particularly in comparison with sub-Saharan Africa. Much of the progress has occurred through diversification along the "extensive margin"- that is, through entry into completely new products.

Structural transformation crucially involves changes not only in the type but also in the quality of goods produced. Emerging Asia has on average benefited significantly from quality upgrading, helping it capitalize on already existing comparative advantages. Yet the potential for quality upgrading varies by product. Agricultural and natural resources tend to have lower potential for quality upgrading than manufactures. Therefore, for frontier countries, diversification into products with longer "quality ladders" may be a necessary first step before large gains from quality improvement can be reaped.

Overall, development strategies must promote sustained resource reallocation and encourage continued quality upgrading. Ongoing work is focused on identifying the specific bottlenecks to structural transformation. In particular, it will analyze measures of product quality in greater detail and examine what policies are needed to promote diversification and to sustain quality upgrading. That said, case studies of individual countries have already yielded some important lessons. For instance, diversification and structural transformation are often underpinned by reforms and policy measures that are general in scope, rather than industry focused and narrowly targeted. In addition, the types of reforms underpinning diversification and structural transformation in the early stages of development are different from those required later on. 


\section{APPENDIX 3.1: DEFINITIONS OF MAIN INDICES}

\section{Herfindahl Index}

As a starting point, we measure diversification using the Herfindahl index. The value of the Herfindahl index, for any given country $i$ and time period $t$, equals the sum of squares of export shares (in total exports), in which the summation is across all goods $j$ in the set $J_{i t}$ of categories which the country exports:

$$
H F I_{i t}=\Sigma_{j \in} J_{i t}\left(X_{i j t} / \Sigma_{k \in} J_{i t} X_{i k t}\right)^{2},
$$

in which $X_{i j t}$ equals the value of exports by country $i$ of good $j$ at time $t$. This is an inverse measure of diversification, which ranges from a maximum of 1 (no diversification: all exports lie in a single category) down to zero (full diversification: each category contains a negligible fraction of the country's exports).

\section{Theil Index}

We calculate the overall, within, and between Theil indices following the definitions and methods used in Cadot, Carrere, and Strauss-Kahn (2011). We first create dummy variables to define each product as "traditional," "new," or "nontraded." Traditional products are goods that were exported at the beginning of the sample, and nontraded goods have zero exports for the entire sample. Thus, for each country and product, the dummy values for traditional and nontraded remain constant across all years of our sample. For each country/year/product group, products classified as "new" must have been nontraded in at least the two previous years and then exported in the two following years. Thus, the dummy values for new products may change over time.

The overall Theil index is a sum of the within and between components. The between Theil index is calculated for each country/year pair as

$$
T_{B}=\sum_{k}\left(N_{k} / N\right)\left(\mu_{k} / \mu\right) \ln \left(\mu_{k} / \mu\right),
$$

in which $k$ represents each group (traditional, new, and nontraded), $N_{k}$ is the total number of products exported in each group, and $\mu_{k} / \mu$ is the relative mean of exports in each group.

The within Theil index for each country/year pair is

$$
T_{W}=\sum_{k}\left(N_{k} / N\right)\left(\mu_{k} / \mu\right)\left\{\left(1 / N_{k}\right) \sum_{i \in} I_{k}\left(x_{i} / \mu_{k}\right) \ln \left(x_{i} / \mu_{k}\right)\right\} .
$$

\section{Product Quality}

Our methodology measures quality based on unit values, but with important adjustments for differences in production costs and for selection bias in the composition of international trade. Henn, Papageorgiou, and Spatafora (2013) provide full details of the methodology. Briefly, we employ a modified version of Hallak (2006), which sidesteps data limitations to achieve maximum country and 
time coverage. ${ }^{3}$ As a first step, for any given product, the trade price (equivalently, unit value) $p_{m x t}$ is assumed to be determined by the following relationship:

$$
\ln p_{m x t}=\zeta_{0}+\zeta_{1} \ln \theta_{m x t}+\zeta_{2} \ln y_{x t}+\zeta_{3} \ln D i s t_{m x}+\xi_{m x t},
$$

in which the subscripts $m, x$, and $t$ denote, respectively, importer, exporter, and time period. Prices reflect three factors: first, quality $\theta_{m x t}$; second, exporter income per capita $y_{x t}$-this is meant to capture cross-country variations in production costs systematically related to income. With high-income countries typically being capital-abundant, we would expect $\zeta_{2}<0$ for capital-intensive sectors and $\zeta_{2}>0$ for labor-intensive sectors. ${ }^{4}$ Third is the (great circle) distance between importer and exporter, Dist ${ }_{m x}$. This accounts for selection bias: typically, the composition of exports to more distant destinations is tilted toward higher-priced goods, because of higher shipping costs. ${ }^{5}$

Next, we specify a quality-augmented gravity equation. This equation is specified separately for each product, because preference for quality and trade costs may vary across products:

$$
\ln (\text { Imports })_{m x i}=I m F E+E x F E+\alpha D i s t_{m x}+\beta I_{m x t}+\delta \ln \theta_{m x t} \ln y_{m t}+\varepsilon_{m x t} .
$$

$I m F E$ and $E x F E$ denote, respectively, importer and exporter fixed effects. Distance is as defined above. The matrix $I_{m x t}$ is a set of standard trade determinants from the gravity literature. ${ }^{6}$ The exporter-specific quality parameter is $\theta_{m x t}$, which enters interacted with the importer's income per capita $y_{m t}$. If $\delta>0$, then greater income increases the "demand for quality."

The estimation equation is obtained by substituting observables for the unobservable quality parameter in the gravity equation. Rearranging equation (3.1) for $\ln \theta_{m x t}$, and substituting into (3.2), yields

$$
\begin{aligned}
\ln (\text { Imports })_{m x t}= & I m F E+E x F E+\alpha D i s t_{m x}+\beta I_{m x t}+\zeta_{1}^{\prime} \ln p_{m x t} \ln y_{m t}+ \\
& \zeta_{2}^{\prime} \ln y_{x t} \ln y_{m t}+\zeta_{3}^{\prime} \ln D i s t_{m x} \ln y_{m t}+\xi_{m x t}^{\prime},
\end{aligned}
$$

in which $\zeta_{1}^{\prime}=\frac{\delta}{\zeta_{1}}, \zeta_{2}^{\prime}=-\frac{\delta \zeta_{2}}{\zeta_{1}}, \zeta_{3}^{\prime}=-\frac{\delta \zeta_{3}}{\zeta_{1}}$, and $\xi_{m x t}^{\prime}=-\frac{\delta \zeta_{0}^{\prime}+\delta \xi_{m x t}}{\zeta_{1}} \ln y_{m t}+\varepsilon_{m x t}$.

\footnotetext{
${ }^{3}$ The key difference is that we directly use unit values at the SITC 4-digit level, whereas Hallak (2006) gathers unit values at the 10-digit level and then normalizes them into a price index for each 2-digit "sector."

${ }^{4}$ This approach builds on Schott (2004), who showed that unit values for any given product vary systematically with exporter relative factor endowments, as proxied by GDP per capita.

${ }^{5}$ Hallak (2006) uses distance to the United States instead of distance to the importer, because it only focuses on prices of exports to the United States. Harrigan, Ma, and Shlychkov (2011) find that the correlation between export prices and distance is due to a composition, or "Washington apples," effect. They also find that U.S. firms charge higher prices to larger and richer markets.

${ }^{6}$ It includes indicator variables for a common border, a common language, the existence of a preferential trade agreement, a colonial relationship, and a common colonizer.
} 
This equation is estimated separately for each of the 851 products in the data set, yielding 851 sets of coefficients. We obtain estimates by two-stage least squares. $\xi_{m x t}$ is a component of $p_{x m t}$, so that the regressor $\ln p_{x m t} \ln y_{m t}$ is correlated with the disturbance term $\xi_{m x t}^{\prime}$. We therefore use $\ln p_{x m t-1} \ln y_{m t}$ as an instrument for $\ln p_{x m t} \ln y_{m t}$. Where a unit value for the preceding year is not available (for instance, because the good was not traded), we use the unit value in the closest available preceding year, going back up to five years. ${ }^{7}$

The regression results are used to calculate a comprehensive set of quality estimates. Rearranging equation (3.1) and using the estimated coefficients, quality is calculated as the unit value adjusted for differences in production costs and for the selection bias stemming from relative distance:

$$
\text { Quality estimate }_{m x t}=\delta \ln \theta_{m x t}=\zeta_{1}^{\prime} \ln p_{m x t}+\zeta_{2}^{\prime} \ln y_{x t}+\zeta_{3}^{\prime} \ln \text { Dist }_{m x} .
$$

As is standard, quality $\theta_{m x t}$ and importers' taste for quality $\delta$ are not separately identified. $^{8}$

The quality estimates are then aggregated into a multilevel database. The estimation yields quality estimates for more than 20 million product-exporterimporter-year combinations. To enable cross-product comparisons, all quality estimates are first normalized by their 90th percentile in the relevant product-year combination. The resulting quality values typically range between zero and 1.2. The quality estimates are then aggregated, using current trade values as weights, to higher-level sectors (Standard International Trade Classification, SITC, 4-, 3-, 2-, and 1-digit, as well as country-level totals). ${ }^{9}$ At each aggregation step, the normalization to the 90th percentile is repeated. Aggregations are also produced based on the Broad Economic Categories classification, as well as for three broad sectors (agriculture, nonagricultural commodities, and manufactures). To allow for easy comparisons with unit values, the latter are also normalized with the 90th percentile set equal to unity.

\footnotetext{
${ }^{7}$ If unit values are not available in any of the preceding five years, the observation is excluded from the estimation.

${ }^{8}$ The preference for quality parameter $\delta$ will also vary by sector. Therefore, when we aggregate quality estimates across sectors, the aggregation will necessarily also aggregate across these heterogeneous preference for quality parameters.

${ }^{9}$ Changes in the higher-level (including country-level) quality estimates will in general reflect both quality changes within disaggregated sectors and reallocation across sectors with different quality levels. If the composition of exports is shifting toward product lines characterized by low quality levels, it is quite possible for the quality of any given product to be rising sharply, but country-level quality to rise slowly (or indeed decline).
} 


\section{APPENDIX 3.2: REGION DEFINITION}

TABLE A3.1

\begin{tabular}{|c|c|c|c|}
\hline \multicolumn{4}{|c|}{ Region Definition } \\
\hline Frontier Asia & Emerging Asia & Sub-Saharan Africa & Western Europe \\
\hline Bangladesh & Brunei Darussalam & Angola & Austria \\
\hline Bhutan & China & Benin & Belgium \\
\hline Cambodia & Fiji & Botswana & Croatia \\
\hline Lao P.D.R. & India & Burkina Faso & Cyprus \\
\hline Maldives & Indonesia & Burundi & Denmark \\
\hline Mongolia & Malaysia & Cameroon & Finland \\
\hline Myanmar & Marshall Islands & Cabo Verde & France \\
\hline Nepal & Micronesia & Central African Republic & Germany \\
\hline Papua New Guinea & Philippines & Chad & Greece \\
\hline \multirow[t]{38}{*}{ Vietnam } & Sri Lanka & Comoros & Iceland \\
\hline & Thailand & Congo, Democratic Republic of & Ireland \\
\hline & Tuvalu & Congo, Republic of & Israel \\
\hline & & Cote d'Ivoire & Italy \\
\hline & & Equatorial Guinea & Luxembourg \\
\hline & & Eritrea & Malta \\
\hline & & Ethiopia & Netherlands \\
\hline & & Gabon & Norway \\
\hline & & Gambia, The & Portugal \\
\hline & & Ghana & Slovak Republic \\
\hline & & Guinea & Slovenia \\
\hline & & Guinea-Bissau & Spain \\
\hline & & Kenya & Sweden \\
\hline & & Lesotho & Switzerland \\
\hline & & Liberia & United Kingdom \\
\hline & & Madagascar & \\
\hline & & Malawi & \\
\hline & & Mali & \\
\hline & & Mauritania & \\
\hline & & Mauritius & \\
\hline & & Mozambique & \\
\hline & & Namibia & \\
\hline & & Niger & \\
\hline & & Nigeria & \\
\hline & & Rwanda & \\
\hline & & Senegal & \\
\hline & & Seychelles & \\
\hline & & Sierra Leone & \\
\hline & & Somalia & \\
\hline & & South Africa & \\
\hline & & Sudan & \\
\hline & & Swaziland & \\
\hline & & São Tomé and Príncipe & \\
\hline & & Tanzania & \\
\hline & & Togo & \\
\hline & & Uganda & \\
\hline & & Zambia & \\
\hline & & Zimbabwe & \\
\hline
\end{tabular}

\section{(C) International Monetary Fund. Not for Redistribution}




\section{APPENDIX 3.3: CASE STUDIES}

Case studies illustrate lessons from structural transformation at different stages of development. The countries considered include Bangladesh with income per capita well below $\$ 1,000$, and Vietnam, a country well on its way to emerging market status. The Vietnam case illustrates lessons from the experiences of countries that have successfully diversified or are successfully diversifying their economies.

Bangladesh illustrates that initial diversification success, to be sustained, requires a combination of further reforms. Diversification in Bangladesh was largely triggered by external factors such as the introductions of the multifiber agreement and the generalized system of preferences in the 1970s. These spurred development of the ready-made garment industry. As a result, Bangladesh shifted rapidly away from traditional agricultural and jute products toward manufacturing (Figure A3.1). Combined with the rise in output from wholesale and retail trade, this contributed to a steady increase in output diversification. Now, however, with ready-made garments accounting for 80 percent of total exports, Bangladesh's output diversification has seemingly peaked, although as a low-cost producer scope remains for further gains through increases in global garment market shares. Attempts to move beyond garments or to increase their quality have been hindered by a lack of supportive reforms. Challenges include poor governance and the high cost of doing business as a result of scarce electricity supplies, severe infrastructure bottlenecks, weak contract enforcement, and expensive credit provision. While such factors did not hinder diversification and inward foreign direct investment (FDI) in the 1990s and early 2000s, they may now be preventing further progress.

In contrast, Vietnam's experience shows that "waves" of supportive reforms can sustain diversification and structural transformation. The first wave of reforms during the 1980s opened new areas of activity to the private sector by reducing barriers to entry and expansion. Domestic prices, external trade, and access to foreign exchange were liberalized; the rationing system largely abolished; subsidies significantly cut back; and inflation reduced. In agriculture, individual land-use rights were recognized, production freed from state-set quotas, and collective assets privatized. As a result, agriculture expanded, rising to almost half of total exports in 1995, and diversified into cash crops, such as coffee and marine and forestry products (Figure A3.2). In a second wave of reforms during the 1990s, liberalization of FDI helped develop other sectors. Initially, FDI was concentrated in the oil sector, but real estate (including hotels), food processing, and heavy and light industry gained importance. FDI helped Vietnam integrate into emerging global supply chains and gradually diversify its output and exports from textiles to footwear and electronics. A diversification of trade partners accompanied this product diversification, first from the Commonwealth of Independent States to Asia and then toward Europe and the United States.

Diversification in frontier economies depends crucially on the frequency with which new products are introduced, the likelihood that they will survive, and 
Bangladesh outout concentration (percent)

Composition of exports (percent)
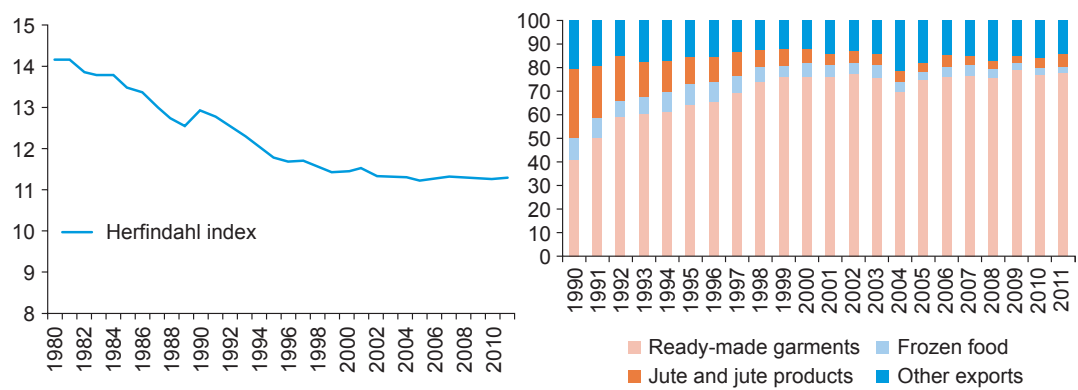

Figure A3.1 Bangladesh: Concentration of Output and Composition of Exports Sources: Country authorities; and IMF staff calculations.

Vietnam: export concentration ${ }^{1}$ (Index)

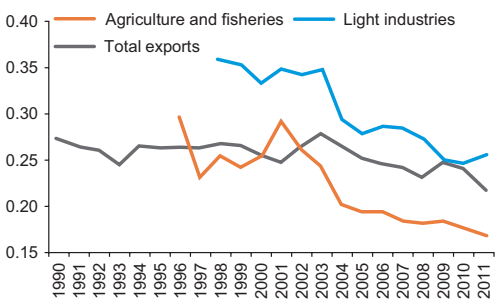

Vietnam: composition of GDP (Percent of total)

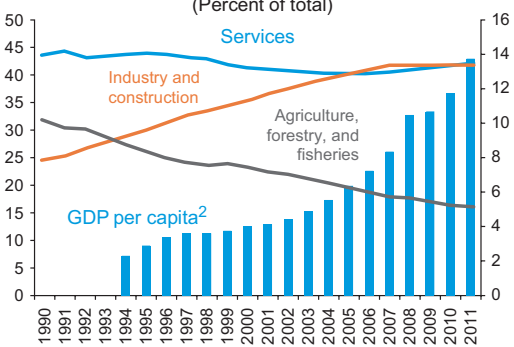

Figure A3.2 Vietnam: Diversification of Exports and Composition of GDP

Sources: Country authorities; and IMF staff calculations.

${ }^{1}$ Sum of squares of individual product shares. A lower number indicates greater diversity.

${ }^{2}$ In hundreds of dollars, right scale.

their growth prospects. Initial trade diversification in frontier economies is mainly driven by entry into new products (the extensive margin). In Vietnam and Bangladesh, over 1990-2011, there were significant differences (over time and across countries) in three key measures of the extensive margin: (1) the number of new product varieties introduced in a given year, ${ }^{10}(2)$ the survival rates of new varieties, (3) and the growth rates of surviving varieties. Over time, such differences can cumulate into large differences in overall exports.

Differences in these measures underline the different experiences of the two countries in our case studies. Vietnam showed significant new entry and reductions over time in the relative importance of incumbent varieties (Figure A3.3). Vietnam in particular stood out as having a high probability of survival of new varieties. Bangladesh had less experimentation and also less growth in surviving varieties, accounting for its current, unusually high concentration.

\footnotetext{
${ }^{10}$ Here, a variety is defined as a specific product exported to a specific country, as in Asmundson (forthcoming).
} 

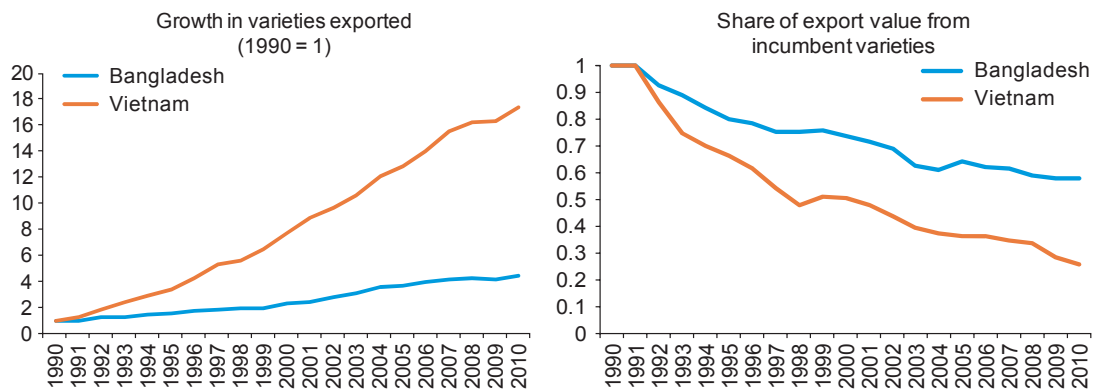

Figure A3.3 Export Experimentation

Sources: UN Comtrade; and IMF staff calculations.

Overall, these case studies provide some tentative evidence in favor of four main themes. First, analyzing the entire structure of production paints a more comprehensive and illuminating picture than focusing purely on external trade. Structural transformation may well be associated with significant diversification of domestic production, including of nontradables. Analyzing this may shed light on the underlying mechanisms and barriers to further transformation.

Second, diversification and structural transformation are often underpinned by reforms and policy measures that are general in scope. Macroeconomic stabilization is a clear example. But even microeconomic measures are often broad based, focusing on improving the quantity and quality of infrastructure or essential business services, or on setting up a welcoming environment for foreign investors. It remains an open issue to what extent industry-focused and narrowly targeted measures have historically helped underpin diversification efforts.

Third, effective policy measures come in waves and aim at exploiting the evolving comparative advantages of the economy in changing external conditions. The types of reforms underpinning diversification and structural transformation in the early stages of development are different from those required later on and need to be adapted to the external environment the economy faces.

Finally, the frequency with which new products are introduced, and the rate at which they grow, can indicate potential policy-driven bottlenecks. Little entry may indicate that barriers deter firms from exporting or experimenting. If survival rates are low, firms may face more obstacles than expected. If surviving firms cannot expand, they may have inadequate access to finance. This type of analysis suggests directions for further study. 


\section{REFERENCES}

Asmundson, Irena. Forthcoming. "More World Trade Flows: An Updating Methodology," IMF Working Paper, International Monetary Fund, Washington.

Berg, A., J. D. Ostry, and J. Zettelmeyer. 2012. "What Makes Growth Sustained?” Journal of Development Economics 98 (2): 149-66.

Cadot, O., C. Carrere, and V. Strauss-Kahn. 2011. "Export Diversification: What's Behind the Hump?" Review of Economics and Statistics 93 (2): 590-605.

Hallak, J. C. 2006. "Product Quality and the Direction of Trade." Journal of International Economics 68: 238-65.

Harrigan, J., X. Ma, and V. Shlychkov. 2011. “Export Prices of U.S. Firms.” NBER Working Paper 17706, National Bureau of Economic Research, Cambridge, Massachusetts.

Hausmann, R., J. Hwang, and D. Rodrik. 2007. "What You Export Matters." Journal of Economic Growth 12 (1): 1-25.

Henn, C., C. Papageorgiou, and N. Spatafora. 2013. "Export Quality in Developing Countries.” IMF Working Paper, No. 13/108. International Monetary Fund, Washington.

International Labour Organization (ILO). 2011. Yearbook of Labor Statistics. Geneva.

Koren, M., and S. Tenreyro. 2007. "Volatility and Development." Quarterly Journal of Economics 122 (1): 243-87.

Mobarak, A. M. 2005. "Democracy, Volatility, and Economic Development." Review of Economics and Statistics 87 (2): 348-61.

Moore, W., and C. Walkes. 2010. "Does Industrial Concentration Impact on the Relationship between Policies and Volatility?" International Review of Applied Economics 24 (2): 179-202.

Papageorgiou, C., and N. Spatafora. 2012. "Economic Diversification in LICs: Stylized Facts and Macroeconomic Implications." IMF Staff Discussion Note 12/13, International Monetary Fund, Washington.

Pitt, A., T. S. Choi, N. Duma, N. Gigineishvili, and S. Rosa. Forthcoming. "Economic Diversification: Experiences and Policy Lessons from Five Case Studies." IMF Working Paper, International Monetary Fund, Washington.

Sachs, J. D., and A. M. Warner. 1995. "Natural Resource Abundance and Economic Growth." NBER Working Paper 5398, National Bureau of Economic Research, Cambridge, Massachusetts.

Samake, I., and Y. Yang. 2011. "Low-Income Countries' BRIC Linkage: Are There Growth Spillovers?” IMF Working Paper 11/267, International Monetary Fund, Washington.

Schott, P. 2004. "Across-Product versus Within-Product Specialization in International Trade." Quarterly Journal of Economics 119 (2): 647-78.

Singer, H. 1950. "US Foreign Investment in Underdeveloped Areas: The Distribution of Gains between Investing and Borrowing Countries." American Economic Review 40 (2): 473-85.

United Nations Industrial Development Organization (UNIDO). 2011. Industrial Statistics Database. Vienna.

\section{(C) International Monetary Fund. Not for Redistribution}


This page intentionally left blank

CInternational Monetary Fund. Not for Redistribution 


\section{Growth Slowdown: Are Frontier and Developing Asian Economies Different?}

\section{LONGMEI Zhang AND DAMIEN PUY}

As is well known, generating growth in low-income countries with low capital stock, limited access to credit, and poor education systems is very challenging, and this phenomenon has been well studied in the "poverty trap" literature. By contrast, the problem of growth slowdowns in low-income countries has received less attention.

Over the past 40 years, several low-income countries have managed to achieve periods of rapid growth, but failed to sustain it. Most notably, several African countries suffered from slowdown and stagnation after an initially promising growth trajectory. A few Asian low-income countries have experienced sustained rapid growth and seem to be on a solid path to middle-income status. Figure 4.1 shows the evolution of log GDP per capita for a set of countries in Africa and Asia once they have reached the income level of $\$ 800$. Note that the slopes of the lines can be read as growth rates. Interestingly, although Ghana, Malawi, and Mauritania reached that level earlier than Cambodia and Vietnam, income levels in the African countries have stagnated in the past four to five decades (with the exception of Ghana in recent years), despite an early start. In addition, their growth paths show much more volatility, with periods of rapid growth being reversed and followed by periods of long stagnation. In contrast, Cambodia and Vietnam have doubled their income levels within two decades, suggesting that success in Asian low-income countries can be translated into sustained rapid growth.

What explains the success in Asia compared with the slowdowns in Africa? Are slowdowns likely to strike low-income countries in Asia? And what are the potential policy measures to avoid such slowdowns?

This chapter addresses these questions by exploring the determinants of growth slowdowns in 58 low-income countries from 1960 to 2005. Building on Aiyar and others (2013), we first identify slowdown episodes in low-income countries using a conditional convergence framework, rather than relying on structural breaks in the time series patterns of growth (Berg, Ostry, and 


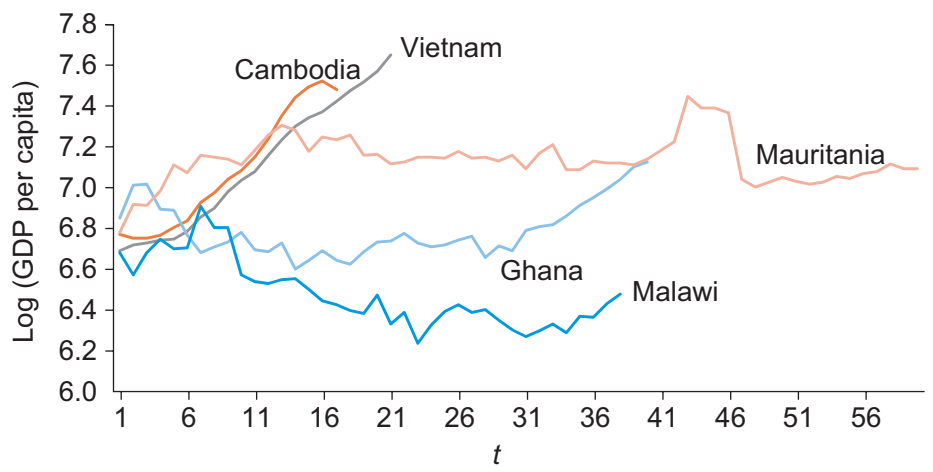

Figure 4.1 Growth Trajectories in Low-Income Countries

Source: IMF staff calculations.

Note: $t=0$ is defined as the year when GDP per capita for a particular country reached $\$ 800$ in purchasing power parity terms or the earliest data available if the starting value is already higher than $\$ 800$. The end period for Vietnam is when the GDP per capita reached $\$ 2,000$ in purchasing power parity terms.

Zettelmeyer 2012). ${ }^{1}$ Having identified "slowdowns," defined as substantial and protracted deviations from a predicted growth path, we then use standard probit analysis and a comprehensive set of explanatory variables to single out the determinants of these episodes. Two variations of Bayesian averaging modeling are then used to assess the robustness of our findings.

We find that the drivers of growth slowdowns in low-income countries are mainly of three types. The first is not economic in essence and involves exogenous natural disasters (droughts, floods) or political conflicts that do not have economic proximate causes. The second type of slowdown is directly related to economic structures. In most cases, low-income countries rely on exports of primary commodities, such as minerals, fuel, and food products, thereby making the economy highly sensitive to external demand and terms-of-trade shocks. And third, slowdowns can be induced by institutional deficiencies and poor macro policies. In this case, growth accelerations and sudden rises in income are followed by adverse institutional evolutions, such as rent seeking, civil wars, and excessive public sector growth, that make it impossible for countries to sustain this temporary growth or transform past income into productive investments.

These findings have important implications for policymaking in Asian lowincome countries. Except for natural disasters, which are exogenous, most of

\footnotetext{
${ }^{1}$ After comparing slowdown episodes with those identified by Berg, Ostry, and Zettelmeyer (2012), we find that more than half of the slowdowns we capture are also captured by their study, and about two-thirds when using a looser criterion of 25 percent significance threshold. However, a substantial number of episodes identified in their study do not qualify in our analysis. Our conditional convergence framework, which is based on a more restrictive definition of slowdowns, therefore yields a substantially lower number of slowdowns compared with Berg, Ostry, and Zettelmeyer (2012).
} 
the identified slowdown drivers can be influenced by appropriate policy interventions. In particular, our results suggest that some countries, such as Mongolia and Papua New Guinea, should diversify their economies and reduce their reliance on natural resource rents. On the other hand, Cambodia and Nepal do not seem to have immediate bottlenecks, but can still improve on most dimensions.

Before turning to the core of this chapter, it is important to note three distinctive features of our analysis with respect to other empirical contributions on growth dynamics in poor countries. First, we address growth slowdowns rather than poverty traps. Although the two phenomena could eventually overlap, we are interested in countries that experienced an abrupt reversal in their growth rate after experiencing a rapid growth period, rather than in countries that always stagnated at very low growth rates or experienced long periods of income stagnation. Therefore we differ from the very considerable literature initiated by Barro (1991), which explores the causes of low growth itself rather than growth reversals. In this respect, we are in line with Pritchett (2000), who called for more attention to "the hills, plateaus, mountains and plains" that are evident in growth records, but remain somewhat understudied, particularly in the case of lowincome countries.

Second, the literature on growth slowdowns has mainly relied on statistical techniques to identify turning points in the growth series (Ben-David and Papell 1998; Berg, Ostry, and Zettelmeyer 2012) or applied intuitive rules of thumb (Hausmann, Rodriguez, and Wagner 2006; Reddy and Minoiu 2009; Eichengreen, Park, and Shin 2011). This study adopts an alternative approach that is better grounded in theory. As stated before, we define growth slowdowns as substantial and sustained deviations from the growth path predicted by the conditional convergence framework.

Thrid, although we rely on the same methodology, we differ from Aiyar and others (2013) in that we focus only on low-income countries and therefore restrict our sample to the determinants of slowdowns in countries with a purchasing power parity income per capita of less than $\$ 2,000$ (measured in 2005 constant prices). We do so because we believe the determinants and nature of slowdowns in low-income countries may be very different from those affecting middle- or high-income economies. In fact, an important conclusion of Aiyar and others (2013) is that the determinants of slowdowns in middle-income countries are different from those identified when using the full sample of 138 countries. ${ }^{2}$

In the rest of this chapter, the first section explains the formal identification procedure of growth slowdowns and comments on the episodes that affected the low-income countries in our sample. The next section outlines the methodology for exploring the determinants of these slowdowns and discusses the key results.

\footnotetext{
${ }^{2}$ See in this respect the role of infrastructure, government size, and regulation. Masanjala and Papageorgiou (2008) also emphasize the peculiarity of growth determinants in low-income countries, showing that determinants of growth in Africa are strikingly different from those in the rest of the world.
} 
The section that follows derives policy implications from these findings, and the final section offers conclusions.

\section{IDENTIFYING GROWTH SLOWDOWNS}

To formally identify the slowdown episodes, we operationalize predictions from conditional convergence theory and identify slowdowns, as noted earlier, as substantial and sustained deviations from the predicted growth path. To do so, we use annual data on income per capita in constant 2005 international dollars and compute a five-year panel of GDP per capita growth rates. ${ }^{3}$ The sample covers 138 countries over 12 periods (1955-2009). ${ }^{4}$ Our specification is parsimonious: GDP per capita growth is regressed on the lagged income level and standard measures of physical and human capital. ${ }^{5}$ For any country at any given point in time, the estimated relationship yields a predicted rate of growth conditional on its level of income and factor endowments.

We define residuals as actual rates of growth minus estimated rates of growth (thus a positive residual means that a country is growing faster than expected and a negative residual means a country is growing slower than expected). Country $i$ experiences a growth slowdown in period $t$ if the two following conditions hold:

$$
\begin{aligned}
& r e s_{t}^{i}-r e s_{t-1}^{i}<p(0.20) \\
& r e s_{t+1}^{i}-r e s_{t-1}^{i}<p(0.20)
\end{aligned}
$$

Here $p(0.20)$ denotes the 20th percentile of the empirical distribution of differences in residuals from one time period to another. Intuitively, condition (4.1) says that between period $t-1$ and $t$ the country's residual became much smaller (that is, its performance relative to the expected pattern deteriorated substantially). To be precise, the deterioration was sufficiently pronounced to place the country-period in the bottom quintile of changes in the residual between successive time periods. The second condition is meant to rule out episodes in which growth slows in the current period only to recover in the next by examining the difference in residuals between periods $t-1$ and $t+1$; that is, over a 10 -year period. ${ }^{6}$ For this chapter, we are more interested in countries that experience sustained slowdowns.

\footnotetext{
${ }^{3}$ We use five-year rolling geometric averages.

${ }^{4}$ The final period, 2006-09, covers only four years due to a lack of subsequent data in the Penn World Tables 7.0.

${ }^{5}$ This represents the most parsimonious established framework for conditional convergence using panel data. The rate of investment in physical capital is taken from the Penn World Tables. The rate of investment in human capital across countries is unavailable, so we follow the standard practice of using the stock of human capital instead; for example, Islam (1995) and Caselli, Esquivel, and Lefort (1996). See Aiyar and others (2013) for detailed calculation methods.

${ }^{6}$ Note that these conditions imply that we cannot identify slowdowns either in our sample's initial period (1955-60), because there is no prior period for comparison, or in the final period (2005-09) because there is no subsequent period for comparison.
} 


\begin{tabular}{|c|c|c|c|c|c|c|c|}
\hline \multicolumn{8}{|c|}{ Slowdowns in Low-Income Countries-Regional Breakdown } \\
\hline Slowdown Variable & $\begin{array}{l}\text { East Asia } \\
\text { and Pacific }\end{array}$ & $\begin{array}{l}\text { Europe and } \\
\text { Central Asia }\end{array}$ & $\begin{array}{c}\text { Latin America } \\
\text { and the } \\
\text { Caribbean }\end{array}$ & $\begin{array}{l}\text { Middle East } \\
\text { and North } \\
\text { Africa }\end{array}$ & South Asia & $\begin{array}{c}\text { Sub-Saharan } \\
\text { Africa }\end{array}$ & Total \\
\hline $0=$ no slow down & 47 & 7 & 11 & 9 & 49 & 193 & 316 \\
\hline 1 = slow down & 3 & & & 2 & 2 & 25 & 32 \\
\hline Total & 50 & 7 & 11 & 11 & 51 & 218 & 348 \\
\hline Slowdown frequency & $6.0 \%$ & & & $18.2 \%$ & $4 \%$ & $11.5 \%$ & $9.2 \%$ \\
\hline
\end{tabular}

Sources: Aiyar and others (2013).

This methodology has at least three desirable characteristics. First, it emphasizes the relative nature of growth slowdowns. At different points in time, the neoclassical growth framework predicts different growth rates for different countries being conditional on world technology, current income, and factor endowments. By identifying growth slowdowns relative to these factors, and also relative to other economies, the methodology takes theory seriously. Second and relatedly, it clarifies what needs to be explained. A slowdown in the headline rate of growth could occur, for example, because a country has already attained a high level of income or because of a temporary shock. But neither of these phenomena needs explanation. Our proposed methodology demarcates countries that are growing slowly after accounting for expected income convergence and after accounting for short-lived shocks. We believe that our methodology passes the "smell test." In particular, it captures the episodes that motivated this study; that is, substantial growth slowdown episodes in Ghana, Malawi, and Mauritania (Figure 4.1).

Table A4.1 (in the appendix) reports the full list of slowdown episodes identified by the criteria in equations (4.1) and (4.2), whereas Table 4.1 summarizes the slowdown variable restricting our sample to low-income countries and breaking down episodes by region. Both tables highlight important stylized facts. First, looking at Table A4.1, we find that growth slowdowns are quite numerous in middle-income countries. In fact, Aiyar and others (2013) show convincingly that middle-income countries are more prone to experience a slowdown than countries in other income classes, relating it to the so-called middle-income trap. ${ }^{7}$ However, Table 4.1 also shows that low-income countries are far from being immune to this phenomenon. We identify 32 episodes out of 348 observations ${ }^{8}$ so that 9 percent of our growth sample in low-income countries consists of growth collapses that are not accounted for by a convergence framework. Finally, we find that most of the slowdowns occurred in sub-Saharan Africa, with some countries, such as Burundi, Liberia, Malawi, and Zimbabwe, accounting for a

\footnotetext{
${ }^{7}$ See Aiyar and others (2013) for an extensive discussion of the middle-income trap.

${ }^{8}$ Although the total sample of low-income countries is made of 441 observations, the sample of "possible" slowdowns is smaller because, by construction, slowdowns cannot be identified in the initial period or in the last one.
} 
third of all slowdown episodes. In fact, only five episodes took place outside Africa-namely in Afghanistan, Indonesia, Lao P.D.R., Mongolia, and Pakistan.

At first glance, this high representation of African countries is clearly reminiscent of Barro's (1991) negative African dummy or the "Africa's growth tragedy" highlighted in Easterly and Levine (1997). However, our diagnosis is somehow less pessimistic insofar as rather than highlighting an "unfulfilled potential, with disastrous consequences," we find that many African countries have in fact often realized their potential but, for reasons that remain to be clarified, failed to sustain these growth spurts. ${ }^{9}$ We now turn to the investigation of the key determinants of slowdown episodes.

\section{DETERMINANTS OF GROWTH SLOWDOWNS IN FRONTIER ECONOMIES}

This section turns to the identification of the drivers of slowdown in low-income countries. Following Eichengreen, Park, and Shin (2011), we estimate the impact of various determinants on the probability of a country experiencing a slowdown in a particular period using standard probit specifications. Because growth slowdowns can be generated by a host of factors, we consider a wide set of 40 potential explanatory variables, which we group into seven categories: economic structure, institutions, infrastructure, demography, trade, macroeconomic environment and policies, and others. Units and sources of these variables are detailed in Table A4.2 (in the appendix).

Note that the actual number of right-hand-side variables used is larger still because, as a general rule, we allow the data to speak to whether these variables influence slowdown probabilities in levels or differences. ${ }^{10}$ Because we are looking at the determinants of sustained slowdowns, we would expect the explanatory variables to matter mostly in differences, but in some cases the level may pick up important threshold effects. We emphasize that these variables have been selected because they all relate to major empirical or theoretical contributions. However, the growth literature from which these potential explanatory variables are taken is too large to be reviewed here. In presenting our results, we will attempt to set the stage by describing some of the intellectual precedents for our chosen variables in each category, but this will necessarily be in an illustrative rather than comprehensive nature. ${ }^{11}$

Our econometric exercise faces two important constraints that shape the empirical approach used in this chapter: data availability and model uncertainty.

\footnotetext{
${ }^{9}$ More generally we support the analysis of Easterly and others (1993), who point out that long-term growth averages "mask important and distinct periods of success and failure" and call for more attention to growth dynamics.

${ }^{10}$ Despite a relatively large body of empirical literature, theories behind growth slowdowns are still at an early stage of development. Here we allow the data to "speak for itself" using variables borrowed from the growth literature.

${ }^{11}$ See Durlauf, Kourtellos, and Tan (2008) for a thorough review.
} 
The first constraint is a recurrent problem in low-income studies (in particular those for African countries), whereby the lack of reliable data often restricts the analysis of qualitative or anecdotal evidence. In our setting, because we consider a vast number of potential regressors, the poor availability of data for low-income countries translates into inevitable data gaps. In particular, we observe a very poor overlap between the different data categories outlined above. For instance, if one were to use all the explanatory variables in a single estimation at the same time, the actual sample size would drop to less than 10 observations (and no slowdowns). To address this issue, we group the 40 variables in seven categories and estimate their impact on slowdowns separately, hoping that a larger sample size and a high overlap within categories will allow us to discriminate between alternative variables of a similar type.

The constraint of model uncertainty, on the other hand, is a standard issue in growth empirics in which ignorance of the "true" model tends to inflate the number of variables on the right-hand scale. When the sample size is limited-a rule rather than an exception in growth empirics_classical estimation methods are of limited use in sorting out robust correlates from irrelevant variables, and growth regressions tend to generate unstable and sometimes contradictory results (Durlauf, Kourtellos, and Tan 2008). Although the sample size considered in this paper is somewhat larger than in many contributions that rely on cross-sectional data, this issue remains relevant. Our approach to addressing model uncertainty is to employ Bayesian model averaging techniques. After every probit estimation, two Bayesian model averaging techniques are used to assess the robustness of the results: the weighted average least squares (WALS) methodology developed by Magnus, Powell, and Prüfer (2010) and the more standard Bayesian model averaging (BMA) developed by Leamer (1979) and popularized by Sala-i-Martin, Doppelhoffer, and Miller (2004).

To summarize, our empirical procedure follows two steps:

1. For each category, we start by running probit specifications with all possible explanatory variables within the specific economic category, both in level and in difference. ${ }^{12}$ We use both backward and forward selection procedures to identify a restricted set of robust regressors.

2. To assess the robustness of the preferred probit specification identified, Bayesian averaging techniques (BMA and WALS) are used over the full set of variables within the economic category of interest.

In line with these two steps, results are presented below for each category and provide (1) the best probit specification (that is, the probit model including variables selected in the first step); (2) the output of the second step under the form of individual post-inclusion probabilities (PIPs) for BMA and $t$-ratios for WALS. Note that Magnus, Powell, and Prüfer (2010) suggest a PIP threshold of 0.5 for

\footnotetext{
${ }^{12}$ Note that we use the lagged levels and difference to minimize the possible endogeneity issues. As for the interpretation, the use of lagged values implies that for a slowdown episode over 1975-80, the 1975 level of variable $X$ is used together with the change in that variable between 1970 and 1975 .
} 
inclusion of a variable, whereas in the case of WALS, a $t$-ratio with an absolute value of 1 or greater is typically recommended as a threshold for significance. We now turn to the results obtained under each category.

\section{Economic Structure and Output Composition}

This module starts by investigating the significance of four variables summarizing the nature and composition of countries' output, namely the (1) industry share (in percent of value added), (2) services share (in percent of value added), (3) mining share (in percent of value added), and (4) a Theil index of output diversification computed by Papageorgiou and Spatafora (2012).

The inclusion of service and industry shares in the value added follows Kuznets' pioneering work on structural transformation (Kuznets 1966). It was Kuznets who first explored what is now regarded as an inevitable accompaniment to modern economic growth: as an economy develops beyond its precapitalist stage, formal employment and output in the manufacturing sector expands, drawing labor from other parts of the economy, especially the initially dominant agricultural sector. The migration of labor from agriculture to manufacturing and the corresponding structural transformation of the economy came to be viewed as the engine of economic development and growth (Harris and Todaro 1970; Lewis 1980). A related aspect of structural transformation is the diversification of output across sectors. Papageorgiou and Spatafora (2012) document an inverse relationship between output diversification (across 12 economy-wide sectors) and real income for countries with a GDP per capita below \$5,000. Imbs and Wacziarg (2003) argue that there is an inherent link between diversification of the product base and growth as poor countries diversify away from agriculture, although this relationship is nonlinear and may be reversed at higher levels of income. Finally, a vast number of empirical and theoretical contributions have documented the complex link between minerals - and natural resources in general-and economic growth. On the one hand, many studies have provided strong empirical support for the "resource curse" hypothesis, generating a second generation of studies that seek to explain the mechanisms through which this effect operates. This includes the so-called Dutch disease, market volatility, unsustainability or institutional side effects (rent seeking, corruption). On the other hand, Masanjala and Papageorgiou (2008) found that the share of mining was significantly and positively related to growth for African countries, suggesting that the presence of natural resources, in particular in Africa, also increased the trend of growth over 1960-2000.

Looking at Table 4.2, we find that the mining share is highly significant (at 1 percent) and associated with a positive coefficient, implying that a higher share of mining increases the probability of experiencing a slowdown. Using Papageorgiou and Spatafora's (2012) index of output diversification covering 12 economy-wide sectors from 2000 onward, we find that sectoral diversification is associated with a lower probability of growth slowdowns. Note, however, that we tested the effect of diversification separately because the coverage is

\section{(C) International Monetary Fund. Not for Redistribution}


TABLE 4.2

\begin{tabular}{|c|c|c|c|c|}
\hline \multicolumn{5}{|c|}{ Economic Structure and Output Composition } \\
\hline \multicolumn{5}{|c|}{ I. Final Probit Specification } \\
\hline \multirow[b]{2}{*}{ Variable } & \multicolumn{2}{|c|}{ Levels } & \multicolumn{2}{|c|}{ Differences } \\
\hline & Coefficient & $P>Z$ & Coefficient & $P>Z$ \\
\hline Mining share & 6.87 & 0.001 & & \\
\hline Pseudo $R^{2}$ & 0.08 & & & \\
\hline Observations & 181 & & & \\
\hline \multicolumn{5}{|c|}{ II. Bayesian Averaging Robustness Tests } \\
\hline & \multicolumn{2}{|c|}{ Levels } & \multicolumn{2}{|c|}{ Differences } \\
\hline & WALS & BMA & WALS & BMA \\
\hline & $t$ & PIP & $t$ & PIP \\
\hline Mining & 2.52 & 0.96 & & \\
\hline Services share & -0.12 & 0.07 & 0.31 & 0.07 \\
\hline Industry share & -0.37 & 0.08 & 1.25 & 0.16 \\
\hline
\end{tabular}

Source: Authors' calculation.

Notes: BMA = Bayesian model averaging, PIP = post-inclusion probability, WALS = weighted average least squares.

poor relative to the other variables in this module. In particular, we are only able to examine slowdowns over $2000-05$, so that the regression collapses to a pure cross-section.

As we emphasized already, the significance of mining is not surprising per se insofar as many studies have highlighted a relationship between natural resources and growth dynamics. Even so, our results complement and qualify those of Masanjala and Papageorgiou (2008). In particular, although the presence of natural resources might increase the trend of mineral-based economies with respect to poorly endowed economies, our results suggest that it also increases the volatility of output. This "double-edged blessing" can be rationalized in several ways. First, countries that rely heavily on mining are typically subject to "mechanical" external demand shocks that can trigger sudden growth periods that are reversed when global prices fall again. For instance, high-performing African countries in the 1960s and 1970s, such as Zambia, experienced massive slowdowns after the collapse of the demand for copper.

A second interpretation, which is in line with Sala-i-Martin and Subramanian (2003) and illustrative of the governance view of the "natural resource curse" hypothesis, is that the reliance on natural resources is problematic because it generates adverse institutional evolutions, such as rent seeking, coups, or civil wars-all of them making it impossible for countries to sustain growth in income or transform past income into productive investments. Collier and Hoeffler (2001) found that the risk of civil war over a five-year period is 20 times higher for countries relying on primary commodity exports. Finally, it might well be a combination of these different effects. For instance, Schuknecht (1999) provides evidence that primary commodity booms tend to lure governments into 
unsustainable increases in spending that result in public bankruptcies once revenues fall again. In this case mechanical external shocks are combined with poor governance and macroeconomic management.

However, the relationship between diversification and growth slowdowns is clearly in line with Imbs and Wacziarg (2003). To the extent that sectoral shocks could lead to slowdown and stagnation in a concentrated economy, diversification is a form of insurance against idiosyncratic shocks to a particular sector and reduces the probability of such an event.

Interestingly, we find that these different interpretations are consistent with the slowdowns captured in our sample. On the one hand, several slowdowns are identified in rich countries that experienced massive civil conflicts with disruptive effects on institutions and investment. In this respect, the long slowdown identified in Liberia between 1980 and 1990 is illustrative. During the 1970s and 1980s, although strong growth was supported by iron mining, which accounted for more than half of Liberia's export earnings, the first Liberian civil war in 1989-96 saw seven rival factions fighting for control of the country's resources (mostly diamonds and iron) and ended up in the destruction of much of the economy and infrastructure. ${ }^{13}$ On the other hand, external shocks combined with poor diversification have also had very disruptive effects, without the interaction of internal civil conflicts. In the late 1970s, despite a growing economy throughout the decade, a global drop in the demand for flue-cured tobacco resulted in massive bankruptcies of tobacco estates in Malawi and a virtual doubling of the debt service ratio in only two years $(1978-80) .^{14}$

\section{Institutions}

It has been long acknowledged that institutions are important, indeed crucial, for growth, but recently much more attention has been paid to analyzing the role of different types of institutions. La Porta and others $(1997,1998)$ influentially argued that the quality of a country's legal institutions-such as legal protection of outside investors - could affect the extent of rent seeking by corporate insiders and thereby promote financial development. ${ }^{15}$ Another strand of the literature has emphasized the advantages of limited government (Buchanan and Tullock 1962; North 1981, 1990; De Long and Shleifer 1993), continuing a tradition that stretches back to Montesquieu and Adam Smith.

\footnotetext{
${ }^{13}$ Sierra Leone, which also experienced a slowdown in early 1990 s, followed the same pattern. Other cases supporting the institutional interpretation of the resource-curse hypothesis have also been studied. For instance, the Nigerian experience-where waste and corruption accounted for a poor longterm economic performance-is explored in detail by Sala-i-Martin and Subramanian (2003).

${ }^{14}$ At this time, the agricultural sector in Malawi accounted for 40 percent of its GDP and 94 percent of exports, most in the form of tobacco exports.

${ }^{15}$ This work has engendered several subsequent contributions emphasizing the importance of legal institutions more broadly.
} 
Mauro (1995) finds that corruption lowers investment, thereby retarding economic growth, although Mironov (1995) cautions that this is true of only certain kinds of corruption. Knack and Keefer (1997) provide evidence that formal institutions that promote property rights and contract enforcement help build social capital, which in turn is related to better economic performance. A large body of literature now exists on the relationship between financial openness and growth; for example, Grilli and Milesi-Feretti (1995); Quinn (1997); and Edwards (2001).

We use five institutional variables in this module. Four are drawn from the Economic Freedom of the World database compiled by the Simon Fraser Institute. The size of government index measures the extent of government involvement in an economy using general government consumption spending (as a percent of GDP). The rule of law index combines indicators of judicial independence, contract enforcement, military interference in the rule of law, protection of property rights, and regulatory restrictions on the sale of real property. The freedom to trade internationally index is constructed from measures of trade taxes, nontariff trade barriers, black market exchange rates, and international capital market controls. The regulation index is an average of subindices measuring credit market regulations, labor market regulations, and business regulations. All four indices are constructed so that a higher value of the index is more "desirable" (that is, a higher value indicates better rule of law, smaller government, more freedom to trade, and less regulation). The fifth variable used here is the ChinnIto Index of financial openness (Chinn and Ito 2006). This is based on binary dummy variables codifying the tabulation of restrictions on cross-border financial transactions reported in the IMF's Annual Report on Exchange Arrangements and Exchange Restrictions.

Table 4.3 shows that greater government involvement in an economy is strongly associated with a higher probability of slowdown. In fact, although the issue of the impact of government size on economic growth is still highly debated empirically, both BMA and WALS find that government size-as measured by the share of government consumption-is a very robust correlate of slowdowns. What explains this strong detrimental effect of government size in our sample? A theoretical interpretation - which is consistent with Guseh $(1997)^{16}$ - is that a large government size hinders economic growth because governments interfere with the efficient allocation of resources, thereby leading to a slowdown in economic growth (Scully 1988). More precisely, governments are (1) inefficient in the provision of Pigouvian goods and services, (2) engage in unproductive rentseeking activities, and (3) deter private enterprise and innovation. This interpretation turns out to be in line with the experience of many African countries that, for much of the postcolonial period, were governed by undemocratic governments with few agricultural or commercial interests. In particular, many

\footnotetext{
${ }^{16}$ Guseh (1997) found that, once fixed effects are controlled for, growth in government size has negative effects on economic growth, but the negative effects are three times as great in nondemocratic socialist systems as in democratic market systems.
}

(C) International Monetary Fund. Not for Redistribution 
TABLE 4.3

\begin{tabular}{|c|c|c|c|c|}
\hline \multicolumn{5}{|l|}{ Institutions } \\
\hline \multicolumn{5}{|c|}{ I. Final Probit Specification } \\
\hline \multirow[b]{2}{*}{ Variable } & \multicolumn{2}{|c|}{ Levels } & \multicolumn{2}{|c|}{ Differences } \\
\hline & Coefficient & $P>Z$ & Coefficient & $P>Z$ \\
\hline Size of government & -0.37 & 0.001 & & \\
\hline Pseudo $R^{2}$ & 0.16 & & & \\
\hline Observations & 113 & & & \\
\hline \multicolumn{5}{|c|}{ II. Bayesian Averaging Robustness Tests } \\
\hline & \multicolumn{2}{|c|}{ Levels } & \multicolumn{2}{|c|}{ Differences } \\
\hline & $\begin{array}{c}\text { WALS } \\
t\end{array}$ & $\begin{array}{l}\text { BMA } \\
\text { PIP }\end{array}$ & $\begin{array}{c}\text { WALS } \\
t\end{array}$ & $\begin{array}{l}\text { BMA } \\
\text { PIP }\end{array}$ \\
\hline Size of government & -2.93 & 0.98 & -0.92 & 0.17 \\
\hline Rule of law & -1.01 & 0.29 & -0.96 & 0.28 \\
\hline Freedom to trade & -0.16 & 0.10 & 1.48 & 0.27 \\
\hline Regulation & -0.12 & 0.09 & 0.80 & 0.11 \\
\hline Chinn-Ito index & 0.73 & 0.08 & -0.92 & 0.11 \\
\hline
\end{tabular}

Source: Authors' calculation.

Notes: $\mathrm{BMA}=$ Bayesian model averaging, PIP = post-inclusion probability, WALS $=$ weighted average least squares.

sub-Saharan countries massively expanded the size of their public sector through public employment and inefficient government spending while imposing wideranging controls on private activity. ${ }^{17}$ As a result, Africa experienced a paradox of poor public services despite relatively high public expenditure and government size (Pradhan 1996). ${ }^{18}$

We find that rule of law is the regressor with the second highest significance, both in level and in difference, suggesting that a better rule of law decreases the likelihood of a slowdown. Unfortunately, the poor overlap between the seven subindices that constitute the final rule of law measure prevents us from using Bayesian averaging methods and determines which dimension of the rule of matters more. However, when running separate probit models on the subindices (using size of government as a control), we find that the extent of military interference in the rule of law and the political process are significant at a 5 percent level. ${ }^{19}$

\footnotetext{
${ }^{17}$ According to Collier and Gunning (1999), public employment was expanded, often as an end in itself. For example, in Ghana by the late 1970s the public sector accounted for three-quarters of formal wage employment), and even in a more market-oriented economy like Kenya, the figure was 50 percent as of 1990 .

${ }^{18}$ This poor service delivery was also said to handicap firms through unreliable transport and power, inadequate telecommunications networks, and unreliable courts. This in turn might have increased the likelihood of a slowdown. See Collier and Gunning (1999) for a review.

${ }^{19}$ The size of government remains significant at 1 percent.
} 


\section{Infrastructure}

Infrastructure conveys beneficial externalities to a range of productive activities and, in many instances, has some characteristics of a public good (for example, a road network might be nonthreatening, at least up to some congestion threshold). It has been incontrovertibly viewed as positively related to economic growth and even as a necessary condition. Nonetheless, a survey by Romp and De Hann (2007) shows that the empirical literature has found mixed results, especially when proxies such as public investment are used to measure infrastructure development. ${ }^{20}$ In this section, we study four kinds of infrastructure development that have been viewed as important by the literature, using data taken from Calderon and Serven (2004) and the World Development Indicators database: (1) telephone lines is the log of telephone lines per 1,000 people, (2) power is the log of gigawatts of generating capacity per 1,000 people, (3) roads is the log of the length of a country's road network per square meter, and (4) cell phones is the number of mobile phone subscriptions per 100 people.

As Table 4.4 shows, we are unable to obtain any significant variable in levels or differences. Given the preponderance of studies showing the importance of infrastructure to growth in the literature, one way to interpret these findings is to note the precise scope of the result-that poor infrastructure by itself is not responsible for sustained periods of growth slowdowns in our sample (and, conversely, good infrastructure is not sufficient to prevent slowdowns caused by other factors). Given the externalities between infrastructure and practically every other economic and social activity, it may be that infrastructure magnifies or retards the impact of other significant determinants of growth slowdowns. For now we leave this question to further research. Second, it is worth noting that Aiyar and others (2013) found that infrastructure matters only if they restrict the sample to middle-income countries, suggesting that the impact of infrastructure on the probability of slowdowns is sensitive to the stage of development of an economy, quite apart from any complementarities with other variables. In the case of low-income countries, it is likely that infrastructure development increases in importance only once the low-income stage of development has been crossed.

\section{Demography}

Population growth subtracts from the rate of growth of output per capita in the Solow model, but the literature has found little systematic impact of population growth itself in cross-country settings. Instead, new research has focused on the age distribution of populations. Several papers document a positive impact on the working-age ratio on economic growth in a cross-section of countries (for example,

\footnotetext{
${ }^{20}$ More recent contributions, and studies using more direct measures of infrastructure, have generally found a more positive impact of public capital on growth (Roller and Waverman 2001; Calderon and Serven 2004; Egert, Kozluk, and Sutherland 2009).
} 
TABLE 4.4

\begin{tabular}{|c|c|c|c|c|}
\hline \multicolumn{5}{|l|}{ Infrastructure } \\
\hline \multicolumn{5}{|c|}{ I. Final Probit Specification } \\
\hline & \multicolumn{2}{|c|}{ Levels } & \multicolumn{2}{|c|}{ Differences } \\
\hline Variable & Coefficien & $P>z$ & Coefficient & $P>Z$ \\
\hline Pseudo $R^{2}$ & 0.16 & & & \\
\hline Observations & 113 & & & \\
\hline \multicolumn{5}{|c|}{ II. Bayesian Averaging Robustness Tests } \\
\hline & \multicolumn{2}{|c|}{ Levels } & \multicolumn{2}{|c|}{ Differences } \\
\hline & WALS & BMA & WALS & BMA \\
\hline & $t$ & PIP & $t$ & PIP \\
\hline Telephone lines & 0.04 & 0.11 & -0.51 & 0.10 \\
\hline Power & 0.53 & 0.17 & 0.54 & 0.09 \\
\hline Road & -0.53 & 0.09 & -0.29 & 0.09 \\
\hline Cell phones & -0.18 & 0.08 & & \\
\hline
\end{tabular}

Source: Authors' calculation.

Notes: BMA = Bayesian model averaging, PIP = post-inclusion probability, WALS = weighted average least squares.

Bloom and Williamson 1998, Bloom and Canning 2004). Others find that national saving rates are strongly connected to demographic structure (Higgins 1998; Kelley and Schmidt 1996; Bloom, Canning, and Malaney 2000; Mason 2001) and that East Asia's economic "miracle" was associated with a major transition in age structure. Another demographic variable of interest is the sex ratio, a measure of gender bias. Sen (1992) and others have argued that the phenomenon of "missing women" reflects the cumulative effect of gender discrimination against all cohorts of females alive today. Gender bias could impact economic growth through higher child mortality, increased fertility rates, and greater malnutrition (Abu-Ghaida and Klasen 2004). In their study of Indian states, Aiyar and Mody (2011) find that a more equal sex ratio is robustly associated with higher economic growth.

We use five variables in this module-namely, annual population growth, fertility rate, old-age dependence ratio, sex ratio, and population density per square meter. Results are reported in Table 4.5. We find that only population density is significant at a 5 percent threshold, implying that higher population density is associated with a lower probability of slowdown. Interestingly, this result parallels those of important studies such as Hagen (1975) and Simon and Gobin (1980), who found a strong and positive association between density and growth using data on 54 countries in the period 1950-70. As argued by Boserup (1975), population density might be positively related to growth-and therefore negatively to slowdowns-because greater density implies different organizations of societies, with denser countries having greater specialization and higher investment levels. In particular, when population density is high, yields fall (as fields are 
TABLE 4.5

\begin{tabular}{|c|c|c|c|c|}
\hline \multicolumn{5}{|l|}{ Demography } \\
\hline \multicolumn{5}{|c|}{ I. Final Probit Specification } \\
\hline \multirow[b]{2}{*}{ Variable } & \multicolumn{2}{|c|}{ Levels } & \multicolumn{2}{|c|}{ Differences } \\
\hline & Coefficient & $P>Z$ & Coefficient & $P>Z$ \\
\hline Population density & -0.004 & 0.04 & & \\
\hline Pseudo $R^{2}$ & 0.02 & & & \\
\hline Observations & 232 & & & \\
\hline \multicolumn{5}{|c|}{ II. Bayesian Averaging Robustness Tests } \\
\hline & \multicolumn{2}{|c|}{ Levels } & \multicolumn{2}{|c|}{ Differences } \\
\hline & $\begin{array}{c}\text { WALS } \\
t\end{array}$ & $\begin{array}{l}\text { BMA } \\
\text { PIP }\end{array}$ & $\begin{array}{c}\text { WALS } \\
t\end{array}$ & $\begin{array}{l}\text { BMA } \\
\text { PIP }\end{array}$ \\
\hline Population growth & 0.34 & 0.07 & -0.56 & 0.07 \\
\hline Fertility rate & 0.58 & 0.08 & 1.02 & 0.14 \\
\hline $\begin{array}{l}\text { Old-age dependence } \\
\text { ratio }\end{array}$ & -0.98 & 0.15 & -0.62 & 0.09 \\
\hline Sex ratio & -0.37 & 0.08 & -0.40 & 0.08 \\
\hline Population density & -0.1 & 0.23 & 0.65 & 0.19 \\
\hline
\end{tabular}

Source: Authors' calculation.

Notes: BMA = Bayesian model averaging, PIP = post-inclusion probability, WALS = weighted average least squares.

fallow for less time), which drives people to develop techniques that enable more frequent cultivation. This requires more labor for regular farm work and for investments in land improvements, increasing output per unit of land (Tiffen 1995). Moreover, at higher densities, social structures and techniques get more complex, implying that the time needed to prepare children increases and education costs are higher. According to Caldwell (1976), this increase in education costs is often accompanied by changes in the nature of marriage, with the family becoming more nuclear. In other words, a higher population density accelerates the demographic transition, facilitating the escape from the Malthusian trap. ${ }^{21}$ In fact, this theory is supported by the negative correlation between population density and fertility rate in our sample $(-0.25)$.

\section{Trade}

A vast literature has explored the importance of the trade structure of economies and its relevance to economic growth and resilience. In this section, we test the significance of five variables that map different facets of the trade structure. Trade openness, measured as the ratio of imports plus exports to GDP (at constant 2005 prices), reflects the degree of trade integration for countries in our sample. Fuel exports and food exports measure the composition of exports of each country and report, respectively, the share of these exports as a percent of GDP. Export

\footnotetext{
${ }^{21}$ More generally, the Commission on Growth and Development (2008) found that urbanization is related to stronger market forces and a shifting and deepening of the knowledge base of the economy.
} 
diversification is measured by a Theil index calculated by Papageorgiou and Spatafora (2012) using product data at the four-digit Standard International Trade Classification level. Distance (GDP weighted) comes from the World Bank and sums, for every country $i$, the distance to every other country $j$ in the world, weighting each distance by country $j$ s share of the world GDP. This captures the disadvantage of a country's geographic location.

The use of an openness measure along with indicators of trade composition relates directly to the importance of the trade channel to explain growth reversals. Admittedly, countries with higher dependence on trade, in particular those relying on primary exports such as food or minerals, are more likely to suffer from global and external shocks. In fact, part of this channel has already been emphasized in an earlier section, which addressed the importance of output composition. Similarly, another strand of the literature looked at export diversification, which has generally been found to be favorably related to growth, especially at an early stage of development. For instance, Koren and Tenreyro (2007) show that economic diversification can increase the resilience of low-income countries to external shocks, and Agosin (2007) provides evidence that export diversification has a positive impact on growth in emerging market economies. Case studies like Gaertner and Papageorgiou (2011) provide similar evidence. Furthermore, distance from world and regional economic centers can be considered an important facet of a country's endowments, with a more favorable geographical location being more conducive to growth through trade. Distance can directly raise transport costs and, by segmenting markets, may reduce scale economies for domestic firms. The work of Redding and Venables (2004) showing the association between distance metrics and income per capita has been replicated by other studies using different samples. ${ }^{22}$

Looking at Table 4.6, we find that both fuel exports and food exports are significant in the probit analysis, although the significance is higher for food exports. This implies that the reliance on primary commodity exports, such as fuel and food products, significantly increases the probability of a slowdown. These finding are clearly in line with those highlighted in the section above on Economic Structure and Output Composition insofar as they both emphasize the importance of international demand shocks for primary commodities ${ }^{23}$ in generating boom-bust cycles. On the other hand, the relatively low significance of export diversification is noteworthy and somehow contrasts with the results presented in the earlier section. For the record, using the index of output diversification, we found that sectoral diversification was associated with a lower probability of growth slowdowns. However, the poor sample coverage of the index

\footnotetext{
${ }^{22}$ For example, Boulhol and de Serres (2010) demonstrate that the relationship is valid even within a panel of advanced economies. Furthermore, economies that take advantage of their geographic location by pursuing regional integration might be thought to improve their growth prospects. Ben-David (1993) showed that trade agreements in Europe have furthered convergence among member countries.

${ }^{23}$ The example of Malawi, detailed earlier, exemplifies this channel.
} 
TABLE 4.6

\begin{tabular}{|c|c|c|c|c|}
\hline \multicolumn{5}{|l|}{ Trade } \\
\hline \multicolumn{5}{|l|}{ I. Final Probit Specification } \\
\hline \multirow[b]{2}{*}{ Variable } & \multicolumn{2}{|c|}{ Levels } & \multicolumn{2}{|c|}{ Differences } \\
\hline & Coefficient & $P>Z$ & Coefficient & $P>Z$ \\
\hline Fuel exports & 0.05 & 0.03 & & \\
\hline Food exports & 0.09 & 0.00 & & \\
\hline Pseudo $R^{2}$ & 0.20 & & & \\
\hline Observations & 101 & & & \\
\hline \multicolumn{5}{|c|}{ II. Bayesian Averaging Robustness Tests } \\
\hline & \multicolumn{2}{|c|}{ Levels } & \multicolumn{2}{|c|}{ Differences } \\
\hline & $\begin{array}{c}\text { WALS } \\
t\end{array}$ & $\begin{array}{l}\text { BMA } \\
\text { PIP }\end{array}$ & $\begin{array}{c}\text { WALS } \\
\boldsymbol{t}\end{array}$ & $\begin{array}{c}\text { BMA } \\
\text { PIP }\end{array}$ \\
\hline Trade openness & 0.04 & 0.10 & 0.19 & 0.11 \\
\hline Fuel exports & 0.80 & 0.35 & -0.16 & 0.18 \\
\hline Food exports & 2.69 & 0.98 & 1.44 & 0.32 \\
\hline Exports diversification & 0.60 & 0.13 & 0.41 & 0.12 \\
\hline Distance & 0.84 & 0.14 & & \\
\hline
\end{tabular}

Source: Authors' calculation.

Notes: $\mathrm{BMA}=$ Bayesian model averaging, PIP = post-inclusion probability, WALS = weighted average least squares .

relative to other variables prevented us from using other controls in the regression. In this module, we find that once we control for what countries specialize inusing fuel and food as a percent of exports along with a measure of diversification-the significance of export diversification disappears. ${ }^{24}$ One interpretation of this finding is that it is not the lack of diversification itself that is problematic but rather the specialization in volatile commodities.

\section{Macroeconomic Environment and Policies}

A large variety of macroeconomic factors have been associated with economic growth and shocks to economic growth. First of all, although domestic investment is certainly crucial to economic growth, there is a long tradition in the literature pointing to the perils of overinvestment (Schumpeter 1912) and boom-bust cycles. For example Hori (2007) argues that the investment slump after the Asian financial crisis (1997-98) was at least partly due to overinvestment prior to the crisis. In turn, investment booms and credit bubbles have often been associated with excessive borrowing and rapid accumulation of public and/or external debt. Inflation has also been linked with negative growth outcomes (Fischer 1993), although Bruno and Easterly (1998) and subsequent contributions emphasize that the relationship is ambiguous when inflation is low to moderate. Finally, a

\footnotetext{
${ }^{24}$ Note that using a probit specification and only the export diversification index as a regressor, we find a result similar to our earlier result: poor export diversification is associated with a higher probability of slowdown.
} 
TABLE 4.7

\begin{tabular}{|c|c|c|c|c|}
\hline \multicolumn{5}{|l|}{ Macro } \\
\hline \multicolumn{5}{|c|}{ I. Final Probit Specification } \\
\hline \multirow[b]{2}{*}{ Variable } & \multicolumn{2}{|c|}{ Levels } & \multicolumn{2}{|c|}{ Differences } \\
\hline & Coefficient & $P>Z$ & Coefficient & $P>Z$ \\
\hline Banking crisis & 0.77 & 0.06 & & \\
\hline Public debt & 0.006 & 0.05 & & \\
\hline Terms of trade & 0.02 & 0.03 & -0.01 & 0.03 \\
\hline Pseudo $R^{2}$ & 0.20 & & & \\
\hline Observations & 117 & & & \\
\hline \multicolumn{5}{|c|}{ II. Bayesian Averaging Robustness Tests } \\
\hline & \multicolumn{2}{|c|}{ Levels } & \multicolumn{2}{|c|}{ Differences } \\
\hline & $\begin{array}{c}\text { WALS } \\
\boldsymbol{t}\end{array}$ & $\begin{array}{l}\text { BMA } \\
\text { PIP }\end{array}$ & $\begin{array}{c}\text { WALS } \\
t\end{array}$ & $\begin{array}{c}\text { BMA } \\
\text { PIP }\end{array}$ \\
\hline Inflation & -0.32 & 0.09 & 0.25 & 0.09 \\
\hline Public debt & 1.27 & 0.17 & & \\
\hline Terms of trade & 1.64 & 0.26 & -1.46 & 0.19 \\
\hline Real exchange rate & -0.28 & 0.10 & 0.12 & 0.10 \\
\hline External debt & 0.38 & 0.09 & 0.25 & 0.09 \\
\hline Investment share & & & -0.16 & 0.08 \\
\hline Banking crisis & 1.53 & 0.42 & & \\
\hline
\end{tabular}

Source: Authors' calculation.

Notes: $\mathrm{BMA}=$ Bayesian model averaging, $\mathrm{PIP}=$ post-inclusion probability, WALS $=$ weighted average least squares.

considerable literature on the relationship between growth and competitiveness exists. For instance, Easterly and others (1993) and Mendoza (1997) find that terms-of-trade shocks can explain part of the variance in growth across countries. Such shocks could be particularly relevant for countries that are large importers or exporters of fuel and food. Relatedly, there is the concern that exporters specializing in natural resources could be subject to Dutch disease. Prasad, Rajan, and Subramanian (2007) find that exchange rate overvaluation may hinder growth in emerging market economies as manufacturing is crowded out by less productive sectors.

The names of the variables used in this module should be mostly selfexplanatory, so we only note the definitions of those that may not be for Table 4.7. "Banking crisis" is a dummy variable drawn from the database constructed and updated by Laeven and Valencia (2012), which takes the value 1 if the country experienced a banking crisis in any of the five years preceding the current year.

Looking at the upper panel of Table 4.7, we find that, according to the probit analysis, high levels of public debt, banking crises, better terms of trade (in level), and adverse terms-of-trade shocks all increase the probability of experiencing a slowdown. One interpretation of the significance of terms of trade, both in level and difference but with opposite signs, is that it captures two different scenarios in our sample. These are the growth collapses that affected poor economies 
importing fuel during the energy crisis in the late 1970s and the mechanical slowdowns that affected fuel exporters during the oil glut of the early 1980s. In the first case, the unprecedented increase in oil prices simply triggered a strong deterioration of local terms of trade and a decrease in growth rates. In the second case, countries with originally high terms of trade experienced a growth collapse in the wake of the drop in global demand for oil. The significance of banking crises, on the other hand, is not surprising and illustrates the high vulnerability of low-income countries to banking crises over the past 40 years. ${ }^{25}$ Finally, the positive effect of public debt on the probability of slowdown is reminiscent of the debt overhang problem (Krugman 1988) that affected many low-income countries in the 1990s and 2000s. In fact, our sample contains several heavily indebted poor countries - most of them in sub-Saharan Africa-that registered very poor economic performance after reaching unsustainable levels of public debt. ${ }^{26}$

\section{Other Determinants}

In the next module (Table 4.8), we consider variables that do not fit easily in any of the previous economic categories. ELF is an index of ethno-linguistic fractionalization, which has often been associated with poor social capital and negative growth outcomes (Easterly and Levine 1997; La Porta and others 1999). "Tropics" measures the fraction of a country's land area that lies in the tropical zone. Various features of this climatic zone, such as poorer land productivity and conditions more favorable to vector-borne diseases could have an adverse impact on growth (Masters and McMillan 2001). Having a large Buddhist population was found by Sala-i-Martin, Doppelhofer, and Miller (2004) to be significantly associated with growth even after controlling for other institutional and cultural factors. Finally, in Table 4.8, the variables of wars and civil conflicts, and natural disasters can clearly depress growth. Looking closely at Table A4.1, we see that several slowdown episodes coincide with notable war and civil conflict episodes, such as the Russian army's invasion of Afghanistan in the 1970s or the HutuTutsi conflicts in Burundi in the 2000s. Floods in Guyana and Zimbabwe in 2005 and droughts in Zimbabwe in 1991 were also associated with growth collapses.

Note that because the variables in this module are either time invariant or plausibly exogenous, they enter the specifications contemporaneously rather than with a lag. Moreover, the nature of the variables considered means that they only enter in levels, not in differences. Using these variables, we find, unsurprisingly, that both wars and civil conflicts and natural disasters are significant. The

\footnotetext{
${ }^{25}$ For a thorough examination of banking crises in both advanced and developing economies, see Reinhart and Rogoff (2008), who state that "the incidence of banking crises proves to be remarkably similar in the high- and middle-to-low-income countries."

26 "It is now widely understood that the crux of sub-Saharan Africa's debt problem is excessive debt overhang, which has led many countries in the region to be classified as insolvent. The severity of the debt crises has impacted negatively on growth in incomes per capita and private investment rates in the region." Elbadawi, Ndulu, and Ndungu (1997).
} 
TABLE 4.8

\begin{tabular}{|c|c|c|c|c|}
\hline \multicolumn{5}{|l|}{ Other Determinants } \\
\hline \multicolumn{5}{|l|}{ I. Final Probit Specification } \\
\hline & \multicolumn{2}{|c|}{ Levels } & \multicolumn{2}{|c|}{ Differences } \\
\hline Variable & Coefficient & $P>Z$ & Coefficient & $P>z$ \\
\hline War and civil conflicts & 0.52 & 0.05 & & \\
\hline Natural disasters & 0.41 & 0.09 & & \\
\hline Pseudo $R^{2}$ & 0.03 & & & \\
\hline Observations & 314 & & & \\
\hline \multicolumn{5}{|c|}{ II. Bayesian Averaging Robustness Tests } \\
\hline & \multicolumn{2}{|c|}{ Levels } & \multicolumn{2}{|c|}{ Differences } \\
\hline & WALS & BMA & WALS & BMA \\
\hline & $t$ & PIP & $t$ & PIP \\
\hline Tropics & 0.97 & 0.09 & & \\
\hline Buddhist & -1.26 & 0.12 & & \\
\hline ELF & 0.97 & 0.06 & & \\
\hline War and civil conflicts & 2.07 & 0.36 & & \\
\hline Natural disasters & 1.76 & 0.22 & & \\
\hline
\end{tabular}

Source: Authors' calculation.

Notes: BMA = Bayesian model averaging, ELF = ethno-linguistic fractionalization index; PIP = post-inclusion probability, WALS $=$ weighted average least squares.

robustness of war is clearly in line with the vast literature studying the economic causes and consequences of conflicts on growth. In the case of low-income countries, a recent contribution by Arbache and Page (2008) has found that conflict in Africa is one of the primary factors associated with growth collapses and stagnation. On the other hand, the importance of natural disasters in driving slowdown episodes reminds us that many low-income countries still have to overcome unfavorable geographic location and severe climatic conditions.

\section{Summary of Findings}

Before turning to policy implications, this section summarizes our main findings. Gathering the different pieces of evidence from the seven modules, we see that slowdowns in low-income countries broadly follow three types of scenarios. The first, which we term "noneconomic," is provoked by events that are not economic in essence, such as exogenous natural disasters (droughts, floods, and so on) or political conflicts that do not have economic proximate causes. For instance, we argue that even though the Afghanistan invasion or the Hutu-Tutsi conflict had very disruptive effects on growth, both conflicts were motivated by strategic or ethnic factors rather than by economic interests. The second type of slowdown, which we denote "economic," characterizes low-income countries that are particularly sensitive to external demand shocks, especially developing economies that are dependent on exports of primary commodities. As we have emphasized, evidence suggests that these external shocks are in general poorly managed and 
cause substantial contractions in output. Third and finally, we term "institutional" the slowdowns that are primarily generated by institutional or social deficiencies. In this case, growth accelerations and sudden rises in income generate adverse institutional outcomes, such as rent seeking, civil wars, or excessive public sector growth that make it impossible for countries to sustain this temporary growth or transform past income into productive investments.

\section{POLICY IMPLICATIONS}

Having identified the different type of slowdowns as well as their robust determinants, we turn to policy implications. In the light of our findings, which are the most vulnerable countries? For instance, are dynamic Asian and African lowincome countries likely to experience a slowdown? Eventually, is there room for policy intervention?

To assess the potential risk, Table 4.9 constructs an illustrative "vulnerability map," which assesses the vulnerabilities of 31 low-income countries in each of the seven dimensions identified as significant in the previous sections. To do so, for each category and each country, we use the latest available data at the country level and look at the country rankings of the 31 countries in each dimension. ${ }^{27}$ By construction, a country ranked 1 displays the greatest risk of slowdown in that category, whereas a country ranked 31 is considered the least risky. ${ }^{28}$ To enhance the interpretation, we also use a color scale in which red indicates a riskier ranking and green denotes a lower ranking relative to other economies featured in the table.

Looking at Table 4.9, we first see that, with few exceptions (Guyana, for example), the highest risks in each dimension are concentrated in the African region. Second, some African countries, such as Ghana, Liberia, and Mauritania, happen to be "structurally" risky in almost all dimensions. For instance, Mauritania has a combination of poor economic diversification, high dependence on primary exports (fuel and food), poor institutions, and high public debt. This makes such countries vulnerable to both economic and institutional slowdowns. However, several African countries display more specific vulnerabilities in one or two dimensions only. For instance, Côte d'Ivoire combines a high dependence on primary exports with high political risk; Burundi combines high natural resources rent with poor institutions. This suggests that Côte d'Ivoire may be more susceptible to both economic and noneconomic slowdowns, whereas Burundi may be more sensitive to institutional slowdowns. And finally, we see that with the exception of Mongolia and Papua New Guinea, low-income countries in Asia

\footnotetext{
${ }^{27}$ We omit infrastructure, which did not yield noteworthy results, as well as population density and natural disaster, which cover variables largely irrelevant from a policy perspective. On the other hand, we proxy for the risk of war and civil conflict using (external and internal) conflict risk ratings computed by the International Country Risk Guide.

${ }^{28}$ In practice, some data points are missing for some countries in each category, so the maximum rank ranges between 30 and 27. Missing data points are reported in gray.
} 
TABLE 4.9

\begin{tabular}{|c|c|c|c|c|c|c|c|c|c|}
\hline \multicolumn{10}{|c|}{ Vulnerability Map } \\
\hline Region & Country & $\begin{array}{c}\text { Natural } \\
\text { Resources } \\
\text { Rent }\end{array}$ & $\begin{array}{l}\text { Political } \\
\text { Risk }\end{array}$ & Institutions & $\begin{array}{l}\text { Public } \\
\text { Debt }\end{array}$ & $\begin{array}{c}\text { Output } \\
\text { Diversification }\end{array}$ & $\begin{array}{c}\text { Food } \\
\text { Exports } \\
\text { (\% GDP) }\end{array}$ & $\begin{array}{l}\text { Fuel Exports } \\
\text { (\% GDP) }\end{array}$ & $\begin{array}{c}\text { Terms of } \\
\text { Trade }\end{array}$ \\
\hline $\begin{array}{l}\text { Latin } \\
\text { America }\end{array}$ & Guyana & 8 & 11 & 3 & 6 & & 1 & 26 & 18 \\
\hline \multirow[t]{6}{*}{ Asia } & Bangladesh & 22 & 3 & 26 & 12 & 13 & 23 & 13 & 22 \\
\hline & Cambodia & 29 & & & 21 & & 26 & 27 & 24 \\
\hline & Mongolia & 4 & 21 & 7 & & 14 & 25 & 4 & \\
\hline & Nepal & 20 & & 21 & 17 & & 22 & 25 & \\
\hline & Philippines & 23 & 11 & 18 & 11 & 21 & 20 & 9 & 19 \\
\hline & $\begin{array}{l}\text { Papua New } \\
\text { Guinea }\end{array}$ & 2 & 16 & 9 & & 15 & & & 3 \\
\hline \multirow[t]{23}{*}{ Africa } & Benin & 26 & & 10 & 20 & 5 & 10 & 19 & 1 \\
\hline & Burundi & 7 & & 4 & 10 & 12 & 18 & 18 & 11 \\
\hline & Cameroon & 9 & 13 & 17 & 27 & 10 & 17 & 3 & 9 \\
\hline & $\begin{array}{l}\text { Central African } \\
\text { Republic }\end{array}$ & 13 & & 15 & 19 & 2 & 27 & 21 & 23 \\
\hline & Cote d’Ivoire & 11 & 3 & 24 & 4 & 19 & 2 & 1 & 13 \\
\hline & Gambia, The & 24 & 20 & & 7 & 8 & 24 & 24 & 25 \\
\hline & Ghana & & 15 & 11 & 14 & 11 & 4 & 8 & 8 \\
\hline & Kenya & 27 & 5 & 7 & 9 & & 9 & 10 & 17 \\
\hline & Lesotho & 28 & & 1 & 15 & 24 & 7 & 15 & 20 \\
\hline & Liberia & 6 & 7 & & 1 & 4 & & & \\
\hline & Malawi & 16 & 16 & 13 & 18 & 9 & 3 & 20 & 12 \\
\hline & Mali & 5 & 1 & 21 & 22 & 7 & 8 & 7 & 21 \\
\hline & Mauritania & 1 & & 5 & 2 & & 5 & 2 & 2 \\
\hline & Mozambique & 10 & 21 & 20 & 16 & 17 & 12 & 5 & 7 \\
\hline & Niger & 21 & 7 & & 26 & & 13 & 14 & 5 \\
\hline & Rwanda & 19 & & 16 & 25 & 6 & 21 & 22 & 4 \\
\hline & Senegal & 25 & 6 & 21 & 13 & 16 & 15 & 6 & 10 \\
\hline & Sierra Leone & 15 & 18 & 14 & & 1 & & & \\
\hline & Tanzania & 12 & 13 & 6 & 5 & 20 & 14 & 17 & 16 \\
\hline & Togo & 17 & 7 & 25 & 3 & 3 & 16 & 23 & 15 \\
\hline & Uganda & 14 & 2 & 12 & 24 & 22 & 11 & 16 & 14 \\
\hline & Zambia & 3 & 19 & 18 & 23 & 23 & 19 & 12 & 6 \\
\hline & Zimbabwe & 18 & 7 & 2 & 8 & 18 & 6 & 11 & \\
\hline
\end{tabular}

Source: Authors' calculation.

(Bangladesh, Cambodia, Nepal, Philippines) tend to have very low levels of risk in most dimensions, implying that Asian low-income countries may be generally at a lower risk of a growth slowdown.

Having identified the relative strength and weaknesses in each dimension for each country, we are now in a position to identify the Asian and African lowincome countries that are most likely to experience a slowdown in the coming years. To do so, Figure 4.2 plots the average rating over all dimensions for a sample of 11 countries in Africa and Asia against the average growth rate over 2008. We find that Ghana, Liberia, and Zimbabwe show very rapid growth over the past four years with a high level of risk. On the other hand, the dynamic low- 


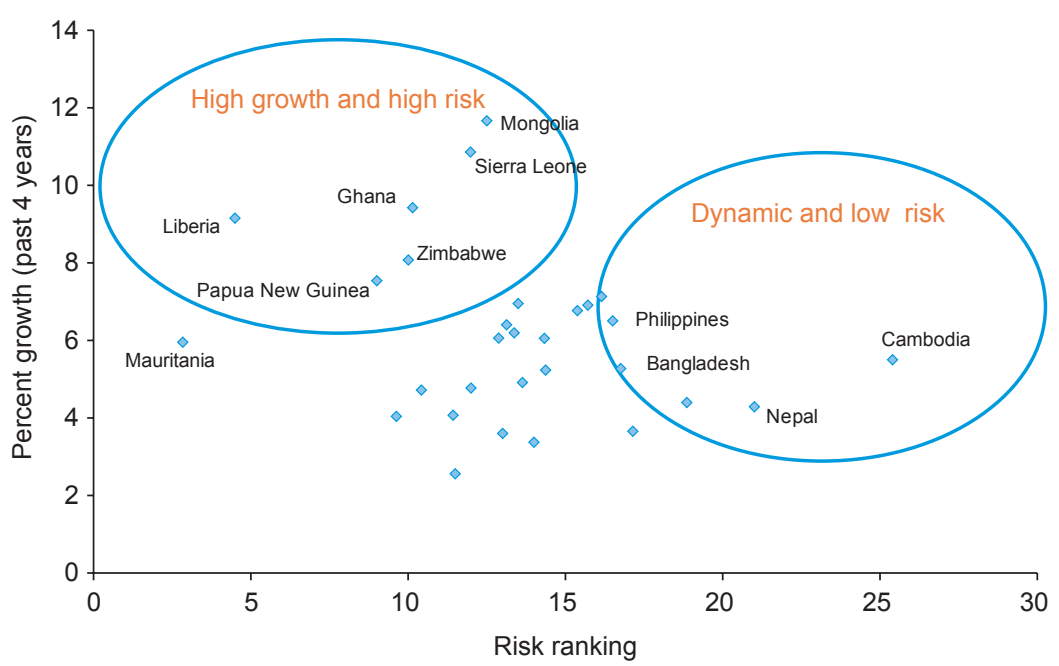

Figure 4.2 Slowdown Risk Map

Source: Author's calculation.

income countries in east and south Asia, which have also experienced sustained growth periods, all have low levels of risk. Overall, this implies that the recent growth dynamics in Asian low-income countries may be more sustainable than in some African countries.

\section{CONCLUSION}

Although many empirical contributions have emphasized that growth is hard to generate in poor countries, we find that sustaining growth is in fact as challenging as achieving it. Using a conditional convergence framework, we found that that 32 growth slowdowns affected low-income countries between 1960 and 2005. Most occurred in sub-Saharan Africa, with a third of all slowdown periods concentrated in four countries. Moreover, probit analysis and Bayesian averaging tests highlighted that several factors can generate substantial and protracted deviations from the predicted growth path, ranging from institutional misalignments and poor economic diversification to exogenous natural disasters. Broadly speaking, the identified slowdowns fall into three categories. The first is noneconomic: the underlying drivers are natural disasters or political conflicts that do not have economic causes. The second is external shocks, especially in countries relying on primary commodity exports. The third type of slowdown is more related to institutional factors: sudden rises in income lead to adverse institutional outcomes, such as rent seeking, civil wars, or excessive public sector growth, making growth unsustainable.

After identifying the slowdowns and their underlying drivers, we then assessed the vulnerability of Asian and African low-income countries to each risk 
factor. Overall, we found that most Asian low-income countries seem less at risk than their African counterparts, albeit with a few exceptions (for example, Mongolia and Papua New Guinea rely heavily on natural resources, and political risks are high in Bangladesh). On the other hand, most African low-income countries show high levels of risk. While the vulnerability of some countries lies in specific dimensions, some African countries face significant slowdown risks along all the dimensions (Mauritania, for example, has a combination of poor economic diversification, high dependence on primary exports, poor institutions, and high public debt). 


\section{APPENDIX}

TABLE A4.1

Growth Slowdown Episodes (by income group)

\begin{tabular}{|c|c|c|c|c|c|c|c|c|c|c|}
\hline \multicolumn{2}{|l|}{ High Income } & \multicolumn{6}{|l|}{ Middle Income } & \multicolumn{3}{|l|}{ Low Income } \\
\hline Japan & 1970-1975 & Algeria & 1980-1985 & Haiti & 1980-1985 & Papua New Guinea & $1995-2000$ & Afghanistan & 1985-1990 Pakistan & $1965-1970$ \\
\hline Japan & 1990-1995 & Algeria & 1985-1990 & Honduras & 1960-1965 & Paraguay & 1980-1985 & Benin & 1985-1990 Sierra Leone & 1990-1995 \\
\hline Finland & $2000-2005$ & Argentina & 1980-1985 & Honduras & 1980-1985 & Peru & $1975-1980$ & Burundi & 1970-1975 Sudan & $2000-2005$ \\
\hline Ireland & $2000-2005$ & Argentina & $1995-2000$ & Indonesia & $1995-2000$ & Peru & 1980-1985 & Burundi & 2000-2005 Togo & 1990-1995 \\
\hline Malta & $2000-2005$ & Belize & 1990-1995 & Iran & 1970-1975 & Poland & 1980-1985 & Cameroon & 1985-1990 Uganda & 1970-1975 \\
\hline Portugal & 1990-1995 & Bolivia & $1975-1980$ & Iran & $1975-1980$ & Portugal & $1970-1975$ & Congo, Republic of & 1970-1975 Zambia & $1975-1980$ \\
\hline Portugal & $2000-2005$ & Botswana & $1975-1980$ & Iraq & 1980-1985 & Romania & $1975-1980$ & Cote d'Ivoire & 1970-1975 Zimbabwe & $1975-1980$ \\
\hline Spain & $1975-1980$ & Botswana & $2000-2005$ & Jamaica & 1970-1975 & Romania & 1980-1985 & Egypt & 1965-1970 Zimbabwe & 1990-1995 \\
\hline Spain & $2000-2005$ & Brazil & $1975-1980$ & Jamaica & 1990-1995 & South Africa & 1980-1985 & Ghana & 1970-1975 Zimbabwe & 2000-2005 \\
\hline Barbados & 1970-1975 & Brazil & $1980-1985$ & Jordan & $1965-1970$ & Spain & $1965-1970$ & Indonesia & $1975-1980$ & \\
\hline Barbados & 1980-1985 & Bulgaria & 1980-1985 & Jordan & 1980-1985 & Swaziland & 1990-1995 & Kenya & 1990-1995 & \\
\hline Barbados & $2000-2005$ & Chile & $1995-2000$ & Korea, Republic of & 1970-1975 & Syria & $1975-1980$ & Lao P.D.R. & $1985-1990$ & \\
\hline Bahrain & $1980-1985$ & Congo, Republic of & $1985-1990$ & Malaysia & $1980-1985$ & Syria & $1980-1985$ & Liberia & 1980-1985 & \\
\hline Cyprus & 1990-1995 & Cyprus & 1980-1985 & Malaysia & $1995-2000$ & Syria & $1995-2000$ & Liberia & $1985-1990$ & \\
\hline Israel & $1975-1980$ & Dominican Republic & 1975-1980 & Maldives & 1985-1990 & Thailand & $1995-2000$ & Liberia & $2000-2005$ & \\
\hline Kuwait & $1995-2000$ & Ecuador & $1975-1980$ & Malta & $1980-1985$ & Tonga & $1985-1990$ & Malawi & $1970-1975$ & \\
\hline Brunei & 1980-1985 & Ecuador & 1980-1985 & Mauritius & $1975-1980$ & Trinidad and Tobago & $1960-1965$ & Malawi & $1975-1980$ & \\
\hline Hong Kong SAR & 1980-1985 & Egypt & $1995-2000$ & Mexico & 1980-1985 & Trinidad and Tobago & $1980-1985$ & Malawi & 1980-1985 & \\
\hline Hong Kong SAR & 1990-1995 & El Salvador & $1975-1980$ & Namibia & 1970-1975 & Tunisia & $1975-1980$ & Mauritania & $1975-1980$ & \\
\hline Korea, Republic of & f $1990-1995$ & El Salvador & $1995-2000$ & Nicaragua & $1965-1970$ & Uruguay & $1995-2000$ & Mongolia & 1990-1995 & \\
\hline Korea, Republic of & f $1995-2000$ & Gabon & $1975-1980$ & Nicaragua & $1985-1990$ & Venezuela & $1975-1980$ & Morocco & $1965-1970$ & \\
\hline Singapore & $1995-2000$ & Guatemala & 1980-1985 & Panama & 1980-1985 & Yemen & $2000-2005$ & Mozambique & $1975-1980$ & \\
\hline & & Guyana & $2000-2005$ & Papua New Guinea & $1980-1985$ & Zambia & $1970-1975$ & Niger & $1980-1985$ & \\
\hline
\end{tabular}

Source: Authors' compilation. 
Independent Variables: Unit and Sources

\begin{tabular}{|c|c|c|c|c|c|}
\hline Descriptions & Sources & Category & Start & End & Frequency \\
\hline Fertility rate, total (births per woman) & WDI & Demography & 1960 & 2009 & Annual \\
\hline Dependency ratio & UN & Demography & 1950 & 2005 & 5-year \\
\hline Sex ratio & UN & Demography & 1950 & 2005 & 5-year \\
\hline Agriculture share of value added (\% of GDP) & WDI & Economic Structure & 1970 & 2011 & Annual \\
\hline Services share of value added (\% of GDP) & WDI & Economic Structure & 1970 & 2011 & Annual \\
\hline Industry share value added (\% of GDP) & WDI & Economic Structure & 1970 & 2011 & Annual \\
\hline Output diversification & Papageorgiou and Spatafora (2012) & Economic Structure & 2000 & 2010 & Annual \\
\hline Telephone lines & Calderon and Serven (2004) & Infrastructure & 1960 & 1995 & 5-year \\
\hline Power generating capacity & Calderon and Serven (2004) & Infrastructure & 1960 & 1995 & 5-year \\
\hline Roads & Calderon and Serven (2004) & Infrastructure & 1960 & 1995 & 5-year \\
\hline Size of government & Economic Freedom Dataset & Institutions & 1960 & 2010 & 5-year \\
\hline Rule of law & Economic Freedom Dataset & Institutions & 1960 & 2010 & 5-year \\
\hline Freedom to trade internationally & Economic Freedom Dataset & Institutions & 1960 & 2010 & 5-year \\
\hline Regulation & Economic Freedom Dataset & Institutions & 1960 & 2010 & 5-year \\
\hline Financial openness & Chinn and Ito (2006) & Institutions & 1970 & 2009 & Annual \\
\hline Gross capital inflows as \% GDP & WEO & MACRO & 1970 & 2009 & Annual \\
\hline Gross capital outflows as \% GDP & WEO & MACRO & 1970 & 2009 & Annual \\
\hline Banking crisis dummy & Laeven and Valencia (2012) & MACRO & 1975 & 2008 & Annual \\
\hline Real exchange rate & IMF staff calculations & MACRO & 1950 & 2009 & Annual \\
\hline Trade openness at 2005 constant prices (\%) & PWT & MACRO & 1950 & 2009 & Annual \\
\hline CPI inflation & WDI & MACRO & 1970 & 2010 & Annual \\
\hline Price level of investment & PWT & MACRO & 1950 & 2009 & Annual \\
\hline External debt (net)-to-GDP ratio & Lane and Milesi-Ferretti (2007) & MACRO & 1970 & 2010 & Annual \\
\hline Public debt-to-GDP ratio & Abbas and others (2010) & MACRO & 1950 & 2010 & Annual \\
\hline Terms of trade & WEO & MACRO & 1970 & 2009 & Annual \\
\hline Reserves-to-GDP ratio & WEO & MACRO & 1970 & 2010 & Annual \\
\hline Investment share of PPP GDP per capita at 2005 constant prices & PWT & MACRO & 1960 & 2010 & Annual \\
\hline Oil exporters' price shock & IMF staff calculations & MACRO & 1950 & 2010 & Annual \\
\hline
\end{tabular}




\begin{tabular}{|c|c|c|c|c|c|}
\hline Food exporters' price shock & IMF staff calculations & MACRO & 1950 & 2010 & Annual \\
\hline Oil importers' price shock & IMF staff calculations & MACRO & 1950 & 2010 & Annual \\
\hline Food importers' price shock & IMF staff calculations & MACRO & 1950 & 2010 & Annual \\
\hline Fraction of country in Tropics & $\begin{array}{l}\text { Sala-i-Martin, Doppelhofer, and } \\
\text { Miller (2004) }\end{array}$ & Other & 1950 & 2010 & Annual \\
\hline Spanish colony & $\begin{array}{l}\text { Sala-i-Martin, Doppelhofer, and } \\
\text { Miller (2004) }\end{array}$ & Other & 1950 & 2010 & Annual \\
\hline Fraction Buddhist & $\begin{array}{l}\text { Sala-i-Martin, Doppelhofer, and } \\
\text { Miller (2004) }\end{array}$ & Other & 1950 & 2010 & Annual \\
\hline Ethno-linguistic fractionalization & $\begin{array}{l}\text { Sala-i-Martin, Doppelhofer, and } \\
\text { Miller (2004) }\end{array}$ & Other & 1950 & 2010 & Annual \\
\hline War and civil conflicts & Correlates of War Project & Other & 1950 & 2010 & Annual \\
\hline Natural disasters & International Disaster Database & Other & 1950 & 2010 & Annual \\
\hline Distance (GDP weighted) & World Bank & TRADE & 1950 & 2010 & Annual \\
\hline Regional integration & IMF staff calculations & TRADE & 1960 & 2010 & Annual \\
\hline Trade diversification: Theil Index & Papageorgiou and Spatafora (2012) & TRADE & 1960 & 2010 & Annual \\
\hline
\end{tabular}

Source: IMF staff.

Note: $\mathrm{CPI}=$ consumer price index, PPP = purchasing power parity, PWT = Penn World Tables, UN = United Nations, WDI = World Bank, World Development Indicators database, WEO = IMF, World Economic Outlook database. 


\section{REFERENCES}

Abbas, S., N. Belhocine, A. ElGanainy, and M. Horton. 2010. "A Historical Public Debt Database.” IMF Working Paper 10/245, International Monetary Fund, Washington.

Abu-Ghaida, D., and S. Klasen. 2004. "The Costs of Missing the Millennium Development Goal on Gender Equity." World Development 32 (7): 1075-1107.

Agosin, M. 2007. "Export Diversification and Growth in Emerging Economies." Working Papers 233, University of Chile, Department of Economics, Santiago.

Aiyar, S., R. Duval, D. Puy, Y. Wu, and L. Zhang. 2013. "Growth Slowdowns and the MiddleIncome Trap.” Working Paper 13/71, International Monetary Fund, Washington.

Aiyar, S., and A. Mody. 2011. "The Demographic Dividend: Evidence from the Indian States?" Working Paper 11/38, International Monetary Fund, Washington.

Arbache, S., and J. Page. 2008. "Hunting for Leopards: Long Run Country Income Dynamics in Africa." Policy Research Working Paper Series 4715, World Bank, Washington.

Barro, R. J. 1991. "Economic Growth in a Cross-Section of Countries." Quarterly Journal of Economics 106 (2): 407-44.

Ben-David, D. 1993. "Equalizing Exchange: Trade Liberalization and Income Convergence." Quarterly Journal of Economics 108 (3): 653-79.

Berg, A., J. D. Ostry, and J. Zettelmeyer. 2012. “What Makes Growth Sustained?” Journal of Development Economics 98 (2): 149-66.

Bloom, D., D. Canning, and P. Malaney. 2000. "Demographic Change and Economic Growth in Asia." Population and Development Review 26 (Supplement): 257-90.

Bloom, D., and D. Canning 2004. "Global Demographic Change: Dimensions and Economic Significance." In Global Demographic Change: Economic Impacts and Policy Challenges, proceedings of a symposium sponsored by the Federal Reserve Bank of Kansas City, Jackson Hole, Wyoming, August 26-28.

Bloom, D., and J. Williamson. 1998. "Demographic Transitions and Economic Miracles in Emerging Asia." World Bank Economic Review 12 (3): 419-55.

Boserup, E. 1975. "The Impact of Population Growth on Agricultural Output.” Quarterly Journal of Economics 89 (2): 257-70.

Boulhol, H., and A. Serres. 2010. "Have Developed Countries Escaped the Curse of Distance?" Journal of Economic Geography 10 (1): 113-39.

Bruno, M., and W. Easterly. 1998. "Inflation Crises and Long-Run Growth." Journal of Monetary Economics 41 (1): 3-26.

Buchanan, J., and G. Tullock. 1962. The Calculus of Consent: Logical Foundations of Constitutional Democracy. Ann Arbor, Michigan: University of Michigan Press.

Calderon, C., and L. Serven. 2004. "The Effects of Infrastructure Development on Growth and Income Distribution.” Policy Research Working Paper Series 3400, World Bank, Washington.

Caldwell, J. C. 1976. “Toward A Restatement of Demographic Transition Theory.” Population and Development Review 2 (3/4): 321-66.

Caselli, F., G. Esquivel, and F. Lefort. 1996. "Reopening the Convergence Debate: A New Look at Cross-Country Growth Empirics." Journal of Economic Growth 1 (3): 363-89.

Chinn, M. D., and H. Ito. 2006. "What Matters for Financial Development? Capital Controls, Institutions, and Interactions." Journal of Development Economics 81 (1): 163-92.

Collier, P., and J. Gunning. 1999. "Why Has Africa Grown Slowly?" Journal of Economic Perspectives 13 (3): 3-22.

Collier, P., and A. Hoeffler. 2001. "On the Duration of Civil War." Policy Research Working Paper Series 2681, World Bank, Washington.

Commission on Growth and Development. 2008. The Growth Report: Strategies for Sustained Growth and Inclusive Development. Washington: World Bank.

De Long, J., and A. Shleifer. 1993. "Princes and Merchants: European City Growth before the Industrial Revolution." Journal of Law and Economics 36 (2): 671-702. 
Durlauf, S. N., A. Kourtellos, and C. M. Tan. 2008. "Are Any Growth Theories Robust?" Economic Journal 118 (527): 329-46.

Easterly, W., M. Kremer, L. Pritchett, and L. H. Summers. 1993. "Good Policy or Good Luck? Country Growth Performance and Temporary Shocks." Journal of Monetary Economics 32 (3): 459-83.

Easterly, W., and R. Levine. 1997. "Africa's Growth Tragedy: Policies and Ethnic Division." Quarterly Journal of Economics 112 (4): 1203-50.

Edwards, S. 2001. "Capital Mobility and Economic Performance: Are Emerging Economies Different?” NBER Working Paper 8076, National Bureau of Economic Research, Cambridge, Massachusetts.

Egert, B., T. Kozluk, and D. Sutherland. 2009. "Infrastructure and Growth: Empirical Evidence." William Davidson Institute Working Paper 957, University of Michigan Business School, William Davidson Institute, Michigan.

Eichengreen, B., D. Park, and K. Shin. 2011. "When Fast Growing Economies Slow Down: International Evidence and Implications for China.” NBER Working Paper 16919, National Bureau of Economic Research, Cambridge, Massachusetts.

Elbadawi, I. A., B. J. Ndulu, and N. Ndungu. 1997. "Debt Overhang and Economic Growth in sub-Saharan Africa." In External Finance for Low-Income Countries, edited by Z. Iqbal and R. Kanbur. Washington: International Monetary Fund.

Fischer, S. 1993. "The Role of Macroeconomic Factors in Growth." Journal of Monetary Economics 32 (3): 485-512.

Gaertner, M., and C. Papageorgiou. 2011. "Sustaining Tanzania’s High Growth Path through Exports." Unpublished. International Monetary Fund, Washington.

Grilli V., and G. Milesi-Ferretti. 1995. "Economic Effects and Structural Determinants of Capital Controls.” Working Paper 95/31, International Monetary Fund, Washington.

Guseh, J. S. 1997. "Government Size and Economic Growth in Developing Countries: A Political-Economy Framework." Journal of Macroeconomics 19 (1): 175-92.

Hagen, E. E. 1975. The Economics of Development. Homewood, Illinois: Irwin.

Harris, J., and M. Todaro. 1970. "Migration, Unemployment and Development: A Two-Sector Analysis." American Economic Review 60 (1): 126-42.

Hausmann, R., F. Rodriquez, and R. Wagner. 2006. "Growth Collapses." Working Paper Series 06-046, Harvard University, John F. Kennedy School of Government, Cambridge, Massachusetts.

Higgins, M. 1998. "Demography, National Savings, and International Capital Flows." International Economic Review 39 (2): 343-69.

Hori, M. 2007. "Investment Recovery from Financial Crises: A View from Cross Country Experiences." In Thailand: Selected Issues, IMF Country Report 07/231. Washington: International Monetary Fund.

Imbs, J., and R. Wacziarg. 2003. "Stages of Diversification." American Economic Review 93 (1): 63-86.

Islam, N. 1995. "Growth Empirics: A Panel Data Approach." Quarterly Journal of Economics 110 (4): 1127-70.

Knack, S., and P. Keefer. 1997. "Does Social Capital Have an Economic Payoff? A CrossCountry Investigation." Quarterly Journal of Economics 112 (4): 1251-88.

Kelley, A., and S. Schmidt. 1996. "Saving, Dependency and Development." Journal of Population Economics 9 (4): 365-86.

Krugman, P. 1988. "Financing vs. Forgiving a Debt Overhang." Journal of Development Economics 29 (3): 253-68.

Koren, M., and S. Tenreyro. 2007. "Volatility and Development." Quarterly Journal of Economics 122 (1): 243-287

Kuznets, S. 1966. Modern Economic Growth, Rate, Structure and Spread. New Haven, Connecticut and London: Yale University Press. 
Lane, P. R., and G. M. Milesi Ferretti. 2007. "The External Wealth of Nations Mark II: Revised and Extended Estimates of Foreign Assets and Liabilities, 1970-2004." Journal of International Economics 73 (November): 223-50.

Laeven L., and P. Valencia. 2012. "Systemic Banking Crises Database: An Update." Working Paper 12/163, International Monetary Fund, Washington.

La Porta, R., F. Lopez-de-Silanes, A. Shleifer, and R. Vishny. 1997. "Legal Determinants of External Finance." Journal of Finance 52 (3): 1131-50.

—. 1998. "Law and Finance." Journal of Political Economy 106 (6): 1113-55.

1999. "The Quality of Government." Journal of Law, Economics and Organization 15 (1): 222-79.

Leamer, E. E. 1979. "Specification Search: Ad Hoc Inference with Nonexperimental Data." Journal of Economic Literature 17 (2): 566-68.

Lewis, W. A. 1980. "The Slowing Down of the Engine of Growth." American Economic Review 70 (4): 555-64.

Magnus, J. R., O. Powell, and P. Prüfer. 2010. "A Comparison of Two Model-Averaging Techniques with an Application to Growth Empirics." Journal of Econometrics 154 (2): 13953.

Masanjala, W., and C. Papageorgiou. 2008. "Rough and Lonely Road to Prosperity: A Reexamination of the Sources of Growth in Africa Using Bayesian Model Averaging." Journal of Applied Econometrics 23 (5): 671-82.

Mason, A. 2001. "Population, Capital, and Labor." In Population Change and Economic Development in East Asia: Challenges Met, Opportunities Seized, edited by A. Mason. Stanford: Stanford University Press.

Masters, W., and M. McMillan. 2001. "Climate and Scale in Economic Growth." Journal of Economic Growth 6 (3): 167-86.

Mauro, P. 1995. "Corruption and Growth." Quarterly Journal of Economics 110 (3): 681712 .

Mendoza, E. 1997. "Terms of Trade Uncertainty and Economic Growth.” Journal of Economic Development 54 (2): 323-56.

Minsky, H. 1986. Stabilizing an Unstable Economy. New Haven, Connecticut: Yale University Press.

Minsky, H. 1992. "The Financial Instability Hypothesis.” Jerome Levy Economics Institute Working Paper 74, Jerome Levy Economics Institute, Annandale-on-Hudson, New York.

Mironov, M. 1995. "Corruption and Growth." Quarterly Journal of Economics 110 (3): 681712.

North, D. 1981. Structure and Change in Economic History. New York: Norton \& Co. . 1990. Institutions, Institutional Change, and Economic Performance. Cambridge, United Kingdom: Cambridge University Press.

Papageorgiou, C., and Nikola Spatafora. 2012. "Economic Diversification in Low-Income Countries: Stylized Facts and Macroeconomic Implications.” IMF Staff Discussion Note 12/13. International Monetary Fund, Washington.

Pradhan, S. 1996. "Evaluating Public Spending: A Framework for Public Expenditure Reviews." World Bank Discussion Papers, World Bank, Washington.

Prasad, E., R. Rajan, and A. Subramanian. 2007. "Foreign Capital and Economic Growth." NBER Working Paper 13619, National Bureau of Economic Research, Cambridge, Massachusetts.

Pritchett, L. 2000. "Understanding Patterns of Economic Growth: Searching for Hills among Plateaus, Mountains, and Plains." World Bank Economic Review 14 (2): 221-50.

Quinn, D. 1997. "The Correlates of Change in International Financial Regulation." American Political Science Review 91(September): 531-51.

Redding, S., and A. Venables. 2004. "Geography and Export Performance: External Market Access and Internal Supply Capacity." In Challenges to Globalization: Analyzing the Economics, edited by R. E. Baldwin and L. A. Winters. Chicago: University of Chicago Press. 
Reddy, S., and C. Minoiu. 2009. "Real Income Stagnation of Countries 1960-2001." Journal of Development Studies 45 (1): 1-23.

Reinhart, C., and K. Rogoff. 2008. "Banking Crises: An Equal Opportunity Menace.” NBER Working Paper 14587, National Bureau of Economic Research, Cambridge, Massachusetts.

Roller, L., and L. Waverman. 2001. "Telecommunications Infrastructure and Economic Development: A Simultaneous Approach.” American Economic Review 91 (4): 909-23.

Romp, W., and J. de Haan. 2007. "Public Capital and Economic Growth: A Critical Survey." Perspektiven der Wirtschaftspolitik 8 (1): 6-52.

Sala-i-Martin, X., G. Doppelhofer, and R. I. Miller. 2004. "Determinants of Long-Term Growth: A Bayesian Averaging of Classical Estimates (BACE) Approach.” American Economic Review 94 (4): 813-35.

Sala-i-Martin, X., and A. Subramanian. 2003. "Addressing the Natural Resource Curse: An Illustration from Nigeria." NBER Working Paper 9804, National Bureau of Economic Research, Cambridge, Massachusetts.

Schuknecht, L., 1999. “Tying Governments' Hands in Commodity Taxation.” Journal of African Economies 8 (2): 152-81.

Schumpeter, J. 1912. The Theory of Economic Development. Cambridge, Massachusetts.

Scully, G. W. 1988. "The Institutional Framework and Economic Development." Journal of Political Economy 96 (3): 652-62.

Sen, A. 1992. Inequality Reexamined. Oxford: Oxford University Press.

Simon, J. L., and R. Gobin. 1980. "The Relationship between Population and Economic Growth in LCD's." In Research in Population Economics 2, edited by J. L. Simon and J. DaVanzo. London: J A I Press.

Tiffen, M. 1995. "Population Density, Economic Growth and Societies in Transition: Boserup Reconsidered in a Kenyan Case-Study." Development and Change 26 (1): 31-66. 
This page intentionally left blank

CInternational Monetary Fund. Not for Redistribution 


\section{Achieving Inclusive Growth}

\section{Ravi BalakRISHnan, Chad SteinberG, AND MuRTAZa Syed}

Frontier Asian economies are poised for continued rapid growth. ${ }^{1}$ Their per capita incomes may be relatively low compared with the rest of Asia at present, but they are clearly on a path to becoming the next generation of emerging market economies, and their populations will provide the next large market of middle-class consumers. Moreover, these countries are becoming increasingly integrated into a vibrant regional trade network that holds great promise. Lessons from within the region attest to the importance of trade openness as a vehicle for rapid development, and frontier Asian economies appear well placed to step into the global and regional production nexus and move up the value chain.

However, these economies can only make this leap in a sustainable manner if they address key policy challenges. One of the challenges is the need to make growth more inclusive so that the fruits of development are shared equitably across the income levels of their populations. Unless frontier Asia can reverse the rising tide of inequality, its potential for economic takeoff could be undermined.

In some ways, of course, inequitable development is a global issue. Income inequality has risen in most parts of the world since 1990. The academic literature attributes the rise mainly to three factors: globalization, skill-biased technological change, and the decreasing bargaining power of workers. But the rise in inequality in frontier Asia has been unprecedented, compared with both other emerging market regions and with Asia's own historical record of equitable growth between the 1960s and 1980s. The global financial crisis and recent social turmoil in different parts of the world have heightened awareness of the potential impact of rising inequality on economic and social stability and on the sustainability of growth. Such concerns have not bypassed frontier Asia; policymakers throughout the region are looking for ways to arrest rising inequality and make growth more inclusive.

This chapter assesses the links between growth, poverty, and inequality in frontier Asia since the early 1990s. Its main findings are that poverty has fallen significantly in the region, but inequality has increased across most of the group,

\footnotetext{
${ }^{1}$ See Chapter 1 for a definition of frontier Asia. In this chapter, frontier Asia is divided into two subgroups by region: frontier south Asia, comprising Bangladesh, Bhutan, Nepal, and Sri Lanka; and frontier east Asia, comprising Cambodia, Lao P.D.R., Mongolia, and Vietnam. Maldives, Myanmar, and Timor-Leste are not covered because of data limitations.
} 
particularly in frontier south Asia, although that subgroup started from a relatively lower base. The rise in inequality has dampened the impact of growth on poverty reduction. As a result, compared with emerging market regions outside Asia, the recent period of growth has generally been both less inclusive and less pro-poor. In this context, the performance of frontier east Asian economies has so far generally been comparatively better than that in frontier south Asia. To reverse the trends and broaden the benefits of growth in the respective countries, policy measures need to be taken, specifically enhanced public spending on health and education, stronger social safety nets, labor market interventions, financial inclusion, and strengthened governance.

The rest of this chapter is organized as follows: The next section compares recent trends in poverty and inequality in frontier Asia with those in other regions of the world. Then, a regression approach is used to quantify the extent to which growth is pro-poor and inclusive. The section also assesses frontier Asia's performance relative to its peers on these metrics. The subsequent section proposes potential policy interventions for broadening the benefits of frontier Asia's growth. The final section offers concluding thoughts.

\section{STYLIZED FACTS: HOW DOES FRONTIER ASIA COMPARE WITH OTHER EMERGING MARKET REGIONS?}

During the past two decades, growth in most frontier Asian economies has been robust and higher, on average, than in other emerging market regions (Figure 5.1).

This level of growth has enabled a halving of the incidence of extreme poverty, with relatively larger gains in the east Asian subgroup, including Cambodia, Lao P.D.R., and Vietnam. Notwithstanding this remarkable achievement, nearly onethird of the region's population continues to live in extreme poverty, with generally higher poverty headcounts in south Asia (Table 5.1).

Moreover, inequality has increased across most of frontier Asia during the same period, with the exception of Cambodia, Nepal, and Vietnam. This rise in inequality is in sharp contrast to the region's own past record, as well as to the previous three-decade record of fast and equitable growth in Japan, the newly industrialized Asian economies (NIEs), and the members of the Association of Southeast Asian Nations (ASEAN). ${ }^{2}$ In addition, this rise has been higher in frontier south Asia than in all other emerging market regions. Inequality has also risen in frontier east Asia, but by comparatively less. The rise in both subgroups compares unfavorably with trends in the Middle East and North Africa and Latin America, where inequality has fallen since 1990 . With regard to the level of inequality, frontier east Asia stands close to the commonly used Gini warning threshold of 40, with south

\footnotetext{
${ }^{2}$ Newly industrialized Asian economies here refer to Hong Kong SAR, Korea, Singapore, and Taiwan Province of China; ASEAN includes Brunei Darussalam, Cambodia, Indonesia, Lao P.D.R., Malaysia, Myanmar, Philippines, Singapore, Thailand, and Vietnam.
} 
a. Emerging markets: real GDP growth (Annual percent change,1990-2010)

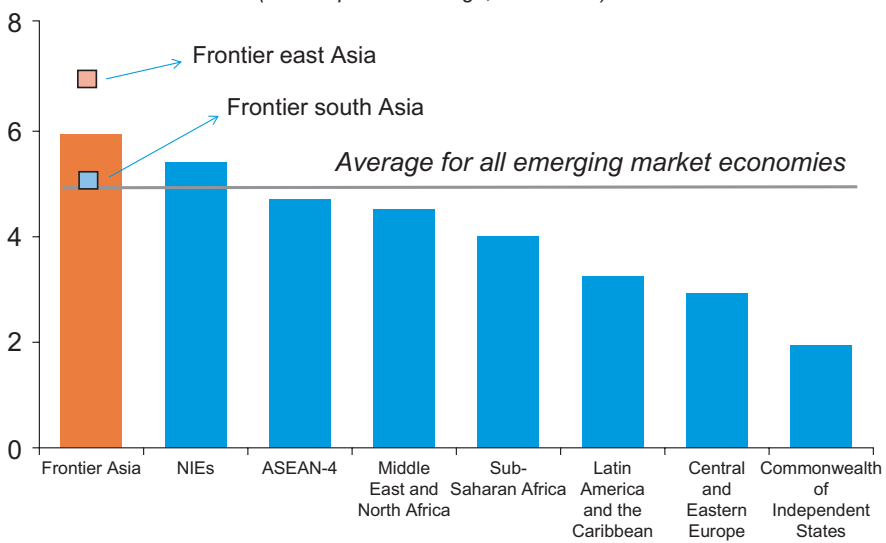

Sources: IMF, World Economic Outlook database.

b. Asia: change in poverty headcount, last two decades ${ }^{1}$ (in percentage points since 1990)

China $(2008,13.1 / 29.8)$ Vietnam $(2008,16.9 / 43.4)$

Nepal (2010. 24.8/57.3)

Indonesia $(2010,18.1 / 46.1)$

Bangladesh (2010, 43.3/76.6)

Lao PDR $(2008,33.9 / 66.0)$

Cambodia $(2008,22.8 / 53.3)$

India $(2010,32.7 / 68.7)$

Thailand $(2009,0.4 / 4.6)$

Philippines (2009, 18.4/41.5)

Sri Lanka $(2007,7.0 / 29.1)$

Malaysia $(2009,0.0 / 2.3)$

Mongolia $(2005,22.4 / 49.1)$

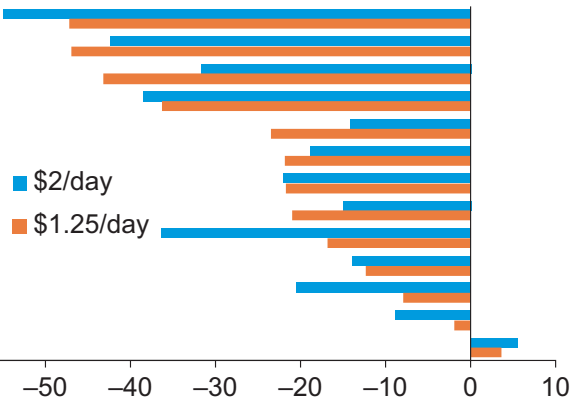

Sources: World Bank; and IMF staff calculations.

${ }^{1}$ At 2005 parity prices. In parentheses, the latest available year and corresponding poverty headcount ratios at $\$ 1.25$ and $\$ 2$ per day, respectively.

c. Asia: change in Gini index, last two decades ${ }^{1}$ (Gini points, since 1990)

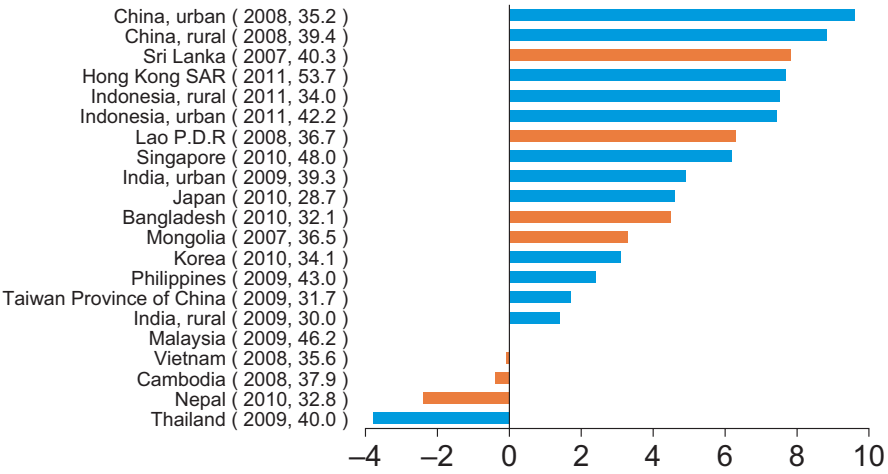

Sources: National authorities; World Bank; and IMF staff calculations.

${ }^{1}$ In parentheses, the latest available year and corresponding Gini coefficients.

Figure 5.1 The Quality of Frontier Asia's Growth

\section{(C) International Monetary Fund. Not for Redistribution}


d. Asia: change in Gini index, pre-19901

(Gini points)

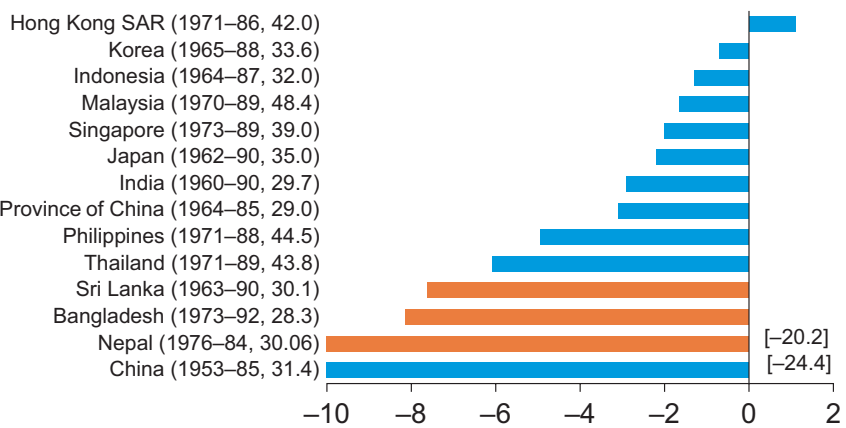

Sources: Milanovic (2010) and IMF staff calculations.

${ }^{1}$ In parentheses, the time period and end value for the Gini coefficients.

e. Emerging economies: change in Gini index, last two decades (Gini points)

Frontier south Asia

Advanced Asia

NIEs

Frontier east Asia

ASEAN-4

Sub-Saharan Africa

Middle East and North Africa

Latin America and the Caribbean

Central and Eastern Europe

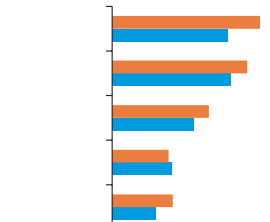

$\begin{array}{lllllllll}-4 & -2 & 0 & 2 & 4 & 6 & 8 & 10 & 12\end{array}$

Sources: CEIC Data Company Ltd.; Milanovic (2010); national authorities; PovcalNet database; WIDER income inequality database; and World Bank.

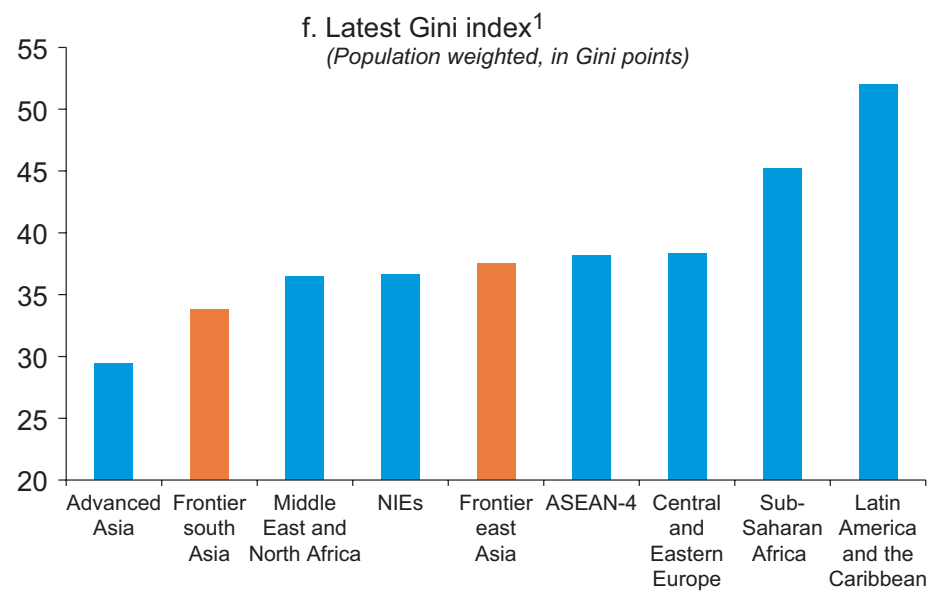

Sources: CEIC Data Company Ltd.; Milanovic (2010); national authorities; PovcalNet database; WIDER income inequality database; World Bank; and IMF staff calculations.

Figure 5.1 (Continued)

\section{(C) International Monetary Fund. Not for Redistribution}




\begin{tabular}{|c|c|c|c|c|c|c|}
\hline \multicolumn{7}{|c|}{ Number of People Living on Less than $\$ 1.25 /$ day (at 2005 PPP prices) } \\
\hline & \multicolumn{2}{|c|}{$\begin{array}{l}\text { Percent of } \\
\text { Population }\end{array}$} & \multirow[t]{2}{*}{$\begin{array}{c}\text { Number } \\
\text { (millions) }\end{array}$} & \multirow{2}{*}{$\begin{array}{c}\text { Percent of } \\
\text { World Total }\end{array}$} & \multirow{2}{*}{$\begin{array}{c}\begin{array}{c}\text { Number } \\
\text { (millions) }\end{array} \\
\end{array}$} & \multirow{2}{*}{$\begin{array}{l}\text { Percent of } \\
\text { World Total } \\
88\end{array}$} \\
\hline & 1990 & 2008 & & & & \\
\hline Europe and Central Asia & 2 & $<1$ & 9 & $<1$ & 2 & 0 \\
\hline Latin America and the Caribbean & 12 & 6 & 53 & 3 & 37 & 3 \\
\hline Middle East and North Africa & 6 & 3 & 13 & 1 & 9 & 1 \\
\hline Sub-Saharan Africa & 57 & 48 & 290 & 15 & 386 & 30 \\
\hline Asia & 55 & 25 & 1,544 & 81 & 855 & 66 \\
\hline China & 60 & 13 & 683 & 36 & 173 & 13 \\
\hline India & 47 & 33 & 433 & 23 & 395 & 31 \\
\hline Frontier and Developing (FD) Asia & 60 & 30 & 138 & 7 & 93 & 7 \\
\hline FD east Asia $^{1}$ & 60 & 19 & 52 & 3 & 20 & 2 \\
\hline FD south Asia ${ }^{2}$ & 61 & 37 & 86 & 5 & 73 & 6 \\
\hline Rest of Asia & 58 & 31 & 289 & 15 & 194 & 15 \\
\hline Total & 43 & 22 & 1,909 & & 1,290 & \\
\hline
\end{tabular}

Source: World Bank, PovcalNet database.

Note: PPP = purchasing power parity.

${ }^{1}$ Includes Cambodia, Lao P.D.R., Mongolia, and Vietnam.

${ }^{2}$ Includes Bangladesh, Nepal, and Sri Lanka.

Asia not far behind. Earlier work (IMF 2006) attributes the rise in inequality in Asia to skill-biased technological change and the transition from agriculture to industry for lower-income economies (consistent with the Kuznets hypothesis). ${ }^{3}$ Also, as seen earlier, although the level of inequality in frontier Asia is generally lower than in other emerging market regions, incomes in the other regions have tended to become more equitable over time.

\section{GROWTH, POVERTY, AND INEQUALITY IN FRONTIER ASIA}

Going beyond these stylized facts, regression analysis can be used to quantify how pro-poor and inclusive growth has been in frontier Asia relative to other emerging market regions. ${ }^{4}$ The following sections discuss the two regions of frontier Asian economies listed in the footnote on page one. ${ }^{5}$

Inclusive and pro-poor growth can be defined in several ways. This analysis follows the approach in Ravallion and Chen (2003) and simply defines growth as

\footnotetext{
${ }^{3}$ Jaumotte, Lall, and Papageorgiou (2008) also argue that skill-biased technological progress is a key driver of rising inequality.

${ }^{4}$ For the econometric analysis, the main sources of data are the latest versions of the World Bank's PovcalNet database (updated in July 2012) and the Penn World Tables Version 7.0. PovcalNet is used because major effort has been made to make its inequality and poverty data comparable across surveys and countries: it draws on 700 household surveys for 120 countries (econ.worldbank.org/povcalnet). Household survey data for the NIEs are added to the PovcalNet data, resulting in an unbalanced panel between 1971 and 2010, with the sample skewed toward the latter part of the period.

${ }^{5}$ The group also includes Malaysia, Thailand, and the Philippines, which are also part of the east Asia group in our results.
} 
pro-poor if it reduces poverty. Inclusive growth, however, is defined as growth that is not associated with an increase in inequality, following Rauniyar and Kanbur (2010). In particular, growth is defined to be inclusive when it is not associated with a reduction in the income share of the bottom quintile of the income distribution.

\section{How Pro-Poor Is Frontier Asia's Growth?}

To examine the relationship between poverty reduction and growth, the following regression is estimated:

$$
\operatorname{In} P_{i, t}=\gamma_{i}+\beta_{i, d} \ln y_{i, t}+\delta \ln G I N I_{i, t}+\rho_{d}+\varepsilon_{i, t},
$$

in which $P_{i, t}$ is the poverty headcount below the $\$ 2 /$ day line in country $i$ at time $t, \gamma_{i}$ is a country dummy, $y_{i, t}$ is per capita income in country $i$ at time $t$, GINI $_{i, t}$ is the Gini coefficient in country $i$ at time $t$, and is $\rho_{d}$ a set of decade dummies. Because the equation is in logs, $\beta$ gives the elasticity of the poverty headcount ratio with respect to income per capita growth (holding the Gini coefficient constant), and $\delta$ gives the elasticity of the poverty headcount ratio with respect to the Gini coefficient (holding per capita income constant). $\beta$ is allowed to vary across country and decade. ${ }^{6}$

A set of benchmark countries needs to be chosen to estimate the fixed effects. These benchmark countries are defined as all economies in the Middle East and North Africa, eastern Europe and central Asia, and sub-Saharan Africa. Latin America is excluded because it is commonly highlighted as being an important exception to the nearly global trend of increasing inequality since 1990 . Therefore, this analysis is interested in explicitly comparing its experience-as well as those of large middle-income economies such as Brazil, China, India, and Indonesia, which are somewhat further along the development path-with that of frontier Asia. An instrumental variables approach is used to take account of endogeneity bias and potential measurement error in the income variable. In particular, lags of real per capita income as measured in the Penn World Tables are used to instrument the household-survey-based average income variable. ${ }^{7}$

\footnotetext{
${ }^{6}$ The regression model follows the literature that argues that although per capita income growth is a key factor, the same rate of growth can bring very different rates of poverty reduction, meaning that other factors matter-in particular, factors that change the income distribution (such as shocks to agricultural incomes, changes in tax regimes, and so forth). Thus, following Ravallion and Chen (1997), this analysis allows poverty to also depend on the Gini coefficient, which proxies for the underlying factors causing a change in the distribution of income. One can think of growth in average income as shifting the income distribution and changes in inequality as modifying the shape of the distribution, both of which can affect the poverty headcount (the cumulative distribution below a line at a particular income level, in this case the $\$ 2 /$ day line).

${ }^{7}$ Specifically, the lagged variables help correct for endogeneity bias by identifying the component of income that is predetermined, and the Penn World Tables measure of income helps correct for measurement error by identifying the component of income, as measured by the household survey, which is also consistent with this secondary measure of income. Because both endogeneity bias and measurement error are relevant, the direction of the bias in the estimates that are not instrumented is uncertain.
} 
TABLE 5.2

\begin{tabular}{|c|c|c|c|c|}
\hline \multicolumn{5}{|l|}{ Pro-Poor Growth Regressions } \\
\hline \multirow[b]{2}{*}{ Variables } & (1) & (2) & (3) & (4) \\
\hline & $p$ & $p$ & $p$ & $p$ \\
\hline \multirow[t]{2}{*}{ Log of mean household income $(y)$} & $-2.146^{* * *}$ & $-8.205^{* * *}$ & $-2.627^{* * *}$ & $-3.406^{* * *}$ \\
\hline & {$[0.262]$} & [1.079] & {$[0.300]$} & {$[0.428]$} \\
\hline \multirow[t]{2}{*}{ Frontier east Asia* $y$} & & & & $1.258^{* *}$ \\
\hline & & & & {$[0.616]$} \\
\hline \multirow[t]{2}{*}{ Frontier south Asia*y } & & & & -0.159 \\
\hline & & & & [1.202] \\
\hline \multirow[t]{2}{*}{ Latin America and Caribbean ${ }^{*} y$} & & & & $1.294^{* * *}$ \\
\hline & & & & {$[0.502]$} \\
\hline \multirow[t]{2}{*}{ China* $y$} & & & & 1.149 \\
\hline & & & & {$[0.712]$} \\
\hline \multirow[t]{2}{*}{ India* $y$} & & & & $1.889^{* * *}$ \\
\hline & & & & {$[0.675]$} \\
\hline \multirow[t]{2}{*}{ Brazil*y $^{*}$} & & & & $1.220 * * *$ \\
\hline & & & & {$[0.436]$} \\
\hline \multirow[t]{2}{*}{ Indonesia* $y$} & & & & $1.957^{* * *}$ \\
\hline & & & & [0.433] \\
\hline \multirow[t]{2}{*}{ Log of Gini index } & $2.258^{* * *}$ & $-5.838^{* * *}$ & $2.277^{* * *}$ & $2.003^{* * *}$ \\
\hline & {$[0.463]$} & [1.205] & {$[0.450]$} & [0.499] \\
\hline \multirow[t]{2}{*}{ Ninety (90s decade dummy) } & & & -0.743 & 0.074 \\
\hline & & & {$[0.536]$} & {$[0.075]$} \\
\hline \multirow[t]{2}{*}{ Noughty (2000s decade dummy) } & & & 0.694 & $0.262^{* *}$ \\
\hline & & & [0.647] & {$[0.112]$} \\
\hline \multirow[t]{2}{*}{ Ninety $^{*} y$} & & & $0.193^{*}$ & \\
\hline & & & {$[0.110]$} & \\
\hline \multirow[t]{2}{*}{ Noughty*y } & & & -0.067 & \\
\hline & & & {$[0.126]$} & \\
\hline \multirow[t]{2}{*}{ Income-Gini interaction } & & $1.723^{* * *}$ & & \\
\hline & & {$[0.267]$} & & \\
\hline Observations & 579 & 579 & 579 & 579 \\
\hline$R$-squared & 0.558 & 0.654 & 0.558 & 0.461 \\
\hline Number of clusters & 98 & 98 & 98 & 98 \\
\hline Model & FE IV & FE IV & FE IV & FE IV \\
\hline
\end{tabular}

Source: Authors.

Note: FE IV = instrumental variables with fixed effects. Dependent variable is log poverty headcount below the $\$ 2$ line. Robust standard errors in brackets. ${ }^{* * *} p<0.01,{ }^{* *} p<0.05,{ }^{*} p<0.1$

The regression results presented in Table 5.2 suggest that growth is in general pro-poor, leading to significant declines in poverty across all economies and time periods. Specifically, a 1 percent increase in real per capita income is associated with a decline of about 2 percent in the poverty headcount ratio (column 1). However, a 1 percent increase in the Gini coefficient almost directly offsets the beneficial impact on poverty reduction of the same increase in income. Moreover, inequality interacts with income, meaning that a higher level of inequality tends to reduce the impact of income growth on poverty reduction (column 2). An increase in the Gini coefficient of about 25 percent reduces the impact of a 1 percent increase in income to about a $1 \frac{1 / 2}{2}$ percent decline in the poverty headcount from 2 percent in the base case. The implication of this result is that higher levels of inequality in frontier Asia are likely to reduce the impact of income

\section{CInternational Monetary Fund. Not for Redistribution}




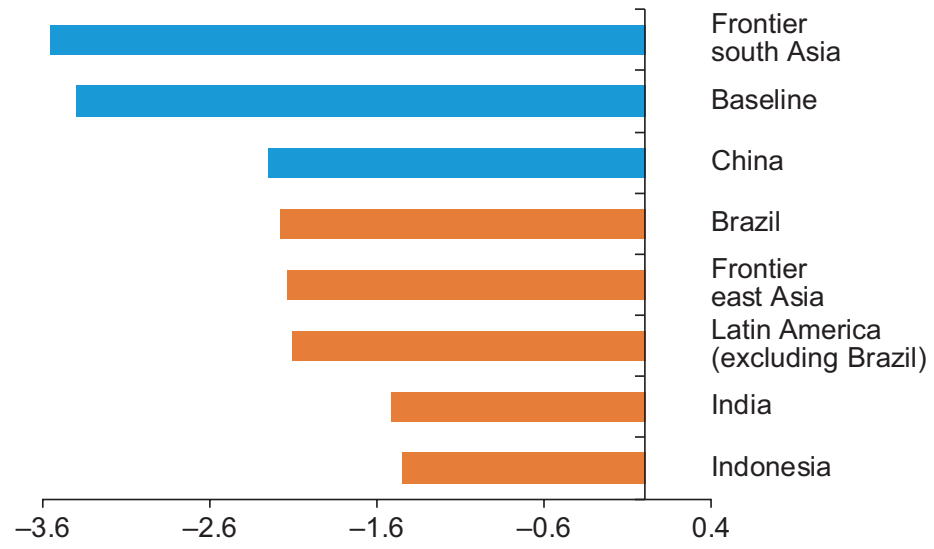

Figure 5.2 Income Elasticity of Poverty Reduction

Sources: Penn World Tables; World Bank, PovcalNet; and IMF staff calculations. Note: The red bars represent countries for which the estimated income elasticity of poverty reduction is significantly different to that of the baseline countries. Figure shows the impact on poverty headcount, in percent, of a 1 percent increase in income per capita.

growth on poverty. In addition, the impact of growth on poverty reduction is found to be somewhat lower during the 1990s, possibly as a result of the changing nature of growth (column 3).

The relationship, however, varies across regions and economies (column 4 and Figure 5.2). Within frontier Asian economies, South Asia's growth has been highly pro-poor. Growth is also pro-poor in frontier east Asian economies, but has a somewhat lower impact on poverty. This impact is also lower than that in the benchmark economies (the Middle East and North Africa, eastern Europe and central Asia, sub-Saharan Africa), although it is still larger than the impacts in India and Indonesia.

\section{How Inclusive Is Frontier Asia's Growth?}

As a second step, the analysis follows Dollar and Kraay (2002) and examines the relationship between per capita income and an income distribution-based definition of "the poor" - now defined as the bottom quintile of the income distribution. If the income of the poor tends to rise equiproportionately with average incomes - that is, income growth is not associated with a decrease in the income share of the bottom quintile- then growth would be considered inclusive. Specifically, the following panel regression model is used:

$$
\ln y p 1_{i, t}=\theta_{i}+\lambda_{i, d} \ln y_{i, t}+\rho_{d}+\varepsilon_{i, t},
$$

in which $y p 1_{i, t}$ is per capita income of the bottom quintile of the income distribution in country $i$ at time $t, \theta_{i}$ is a country dummy, $y_{i, t}$ is per capita income in country $i$ at time $t$, and $\rho_{d}$ is a set of decade dummies. The coefficient $\lambda$, which is allowed to vary across country and decade, is the elasticity of income growth of 
the bottom quintile with respect to growth in average income. Equation (5.2) can be rewritten as

$$
\operatorname{In} Q 1_{i, t}=\theta_{i}+\left(\lambda_{i, d}-1\right) \ln y_{i, t}+\eta_{d}+\varepsilon_{i, t},
$$

in which $Q 1_{i, t}$ is the bottom quintile share of the income distribution in country $i$ at time $t$. As equation (5.3) shows, if $\lambda$ is less than 1 , income growth is associated with a decrease in the income share of the bottom quintile - that is, growth is not inclusive. Equation (5.3) is the model estimated in this analysis. Given that much of the ongoing debate about inclusiveness has not just focused on the poorest fifth of society being left behind, but the richest fifth doing particularly well, a similar relationship for income in the top quintile is also estimated. As with the pro-poor regressions, an instrumental variables approach is used to take account of endogeneity bias and potential measurement error in the income variable.

The results are shown in Table 5.3. If all observations are simply pooled, or if just country-specific effects are used, the analysis yields the familiar Dollar-Kraay result, that average incomes of the poorest fifth of society rise proportionately with per capita income (column 1), which also holds for the richest fifth at the 5 percent significance level (column 4). However, once the exercise instruments for the income variable (columns 2 and 5), the results change: the income of the bottom

TABLE 5.3

\begin{tabular}{|c|c|c|c|c|c|c|}
\hline \multicolumn{7}{|l|}{ Inclusive Growth Regression } \\
\hline Variables & $\begin{array}{c}(1) \\
\ln Q 1\end{array}$ & $\begin{array}{c}(2) \\
\ln Q 1\end{array}$ & $\begin{array}{c}(3) \\
\ln Q 1\end{array}$ & $\begin{array}{c}(4) \\
\ln Q 5\end{array}$ & $\begin{array}{c}(5) \\
\ln Q 5\end{array}$ & $\begin{array}{c}(6) \\
\ln Q 5\end{array}$ \\
\hline Log of mean household income $(y)$ & $\begin{array}{l}-0.025 \\
{[0.043]}\end{array}$ & $\begin{array}{c}-0.142^{* *} \\
{[0.061]}\end{array}$ & $\begin{array}{l}-0.097 \\
{[0.126]}\end{array}$ & $\begin{array}{l}0.040^{*} \\
{[0.023]}\end{array}$ & $\begin{array}{c}0.119 * * * \\
{[0.034]}\end{array}$ & $\begin{array}{c}0.060 \\
{[0.061]}\end{array}$ \\
\hline Frontier East Asia*y & & & $\begin{array}{c}0.126 \\
{[0.180]}\end{array}$ & & & $\begin{array}{l}-0.142 \\
{[0.101]}\end{array}$ \\
\hline Frontier South Asia* $y$ & & & $\begin{array}{c}-0.480 * * * \\
{[0.178]}\end{array}$ & & & $\begin{array}{l}0.390^{* *} \\
{[0.185]}\end{array}$ \\
\hline $\mathrm{NIEs}^{*} y$ & & & $\begin{array}{c}-0.430 * * * \\
{[0.126]}\end{array}$ & & & $\begin{array}{c}0.098 \\
{[0.062]}\end{array}$ \\
\hline Latin America and Caribbean ${ }^{*} y$ & & & $\begin{array}{c}0.133 \\
{[0.186]}\end{array}$ & & & $\begin{array}{l}-0.068 \\
{[0.080]}\end{array}$ \\
\hline China* $^{*}$ & & & $\begin{array}{l}-0.204 \\
{[0.128]}\end{array}$ & & & $\begin{array}{l}0.138^{* *} \\
{[0.062]}\end{array}$ \\
\hline Brazil* $y^{*}$ & & & $\begin{array}{c}0.469 * * * \\
{[0.126]}\end{array}$ & & & $\begin{array}{c}-0.260 * * * \\
{[0.063]}\end{array}$ \\
\hline India*y & & & $\begin{array}{c}0.320 \\
{[0.305]}\end{array}$ & & & $\begin{array}{l}-0.224 \\
{[0.146]}\end{array}$ \\
\hline Indonesia*y & & & $\begin{array}{c}0.049 \\
{[0.133]}\end{array}$ & & & $\begin{array}{l}-0.030 \\
{[0.069]}\end{array}$ \\
\hline Observations & 661 & 633 & 633 & 661 & 633 & 633 \\
\hline$R$-squared & 0.001 & -0.027 & 0.017 & 0.021 & -0.019 & 0.064 \\
\hline Model & $\mathrm{FE}$ & FE IV & FE IV & FE & FE IV & FE IV \\
\hline Number of clusters & 107 & 105 & 105 & 107 & 105 & 105 \\
\hline
\end{tabular}

Source: Authors.

Note: NIEs = newly industrialized economies. FE IV = instrumental variables with fixed effects.

Dependent variable is log share of the income distribution of the bottom/top quintile share. Robust standard errors in brackets. ${ }^{* *} p<0.01,{ }^{* *} p<0.05,{ }^{*} p<0.1$. 


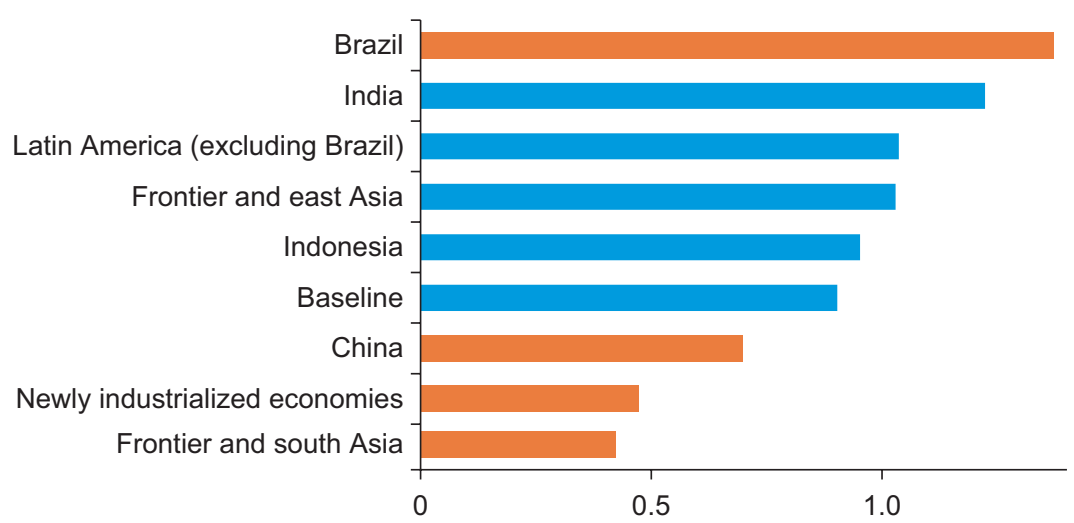

Figure 5.3 Degree of Inclusiveness of Growth

Sources: Penn World Tables; World Bank, PovcalNet; and IMF staff calculations.

Note: The red bars represent countries for which the estimated degree of inclusiveness is significantly different from one. The figure shows the impact on income of the bottom quintile, in percent, of a 1 percent increase in income per capita.

quintile rises significantly less than proportionately with average income, and the income of the top quintile rises significantly more than proportionately with average income - an important departure from the Dollar-Kraay stylized fact. ${ }^{8}$

Moreover, these elasticities vary significantly across regions and countries (columns 3 and 6). For the bottom quintile in frontier Asia, the elasticity is significantly less than 1 for the South Asia group, as it is in China and the NIEs. By contrast, for frontier east Asia, it is equal to 1 for the benchmark economies and Latin America and the Caribbean, and in Brazil, it is significantly greater than 1 (Figure 5.3). ${ }^{\text {? }}$

Turning to the top quintile, the results are generally the mirror image of those for the bottom quintile (Figure 5.4). The elasticity is significantly greater than 1 for frontier south Asia, as well as for China_-and not significantly different from 1 for frontier east Asia nor for the benchmark economies_-and significantly less than 1 for Brazil. ${ }^{10}$

In sum, the results suggest that growth has generally not been inclusive in the frontier south Asian economies, China, and the NIEs. However, it has been inclusive in frontier east Asia, as well as in the Middle East and North Africa, eastern Europe and central Asia, sub-Saharan Africa, Latin America and the Caribbean, and especially Brazil. ${ }^{11}$ This greater equity of frontier east Asia's

\footnotetext{
${ }^{8}$ These results also validate concerns that both measurement error and attenuation bias affected the estimates presented in Dollar and Kraay (2002).

${ }^{9}$ Although the elasticity for China is not significantly different from that of the benchmark baseline economies at the 10 percent level (column 3 of Table 5.3), further $\chi^{2}$ tests show that it is significantly different from 1 at the 1 percent level.

${ }^{10}$ Similar to the result for China in the bottom quintile regression, although the elasticity for the NIEs is not significantly different from that of the benchmark economies at the 10 percent level (column 6 of Table 5.3), it is significantly different from 1 at the 1 percent level.

${ }^{11}$ One important caveat is that Brazil entered the 1990 s with a relatively higher level of inequality.
} 


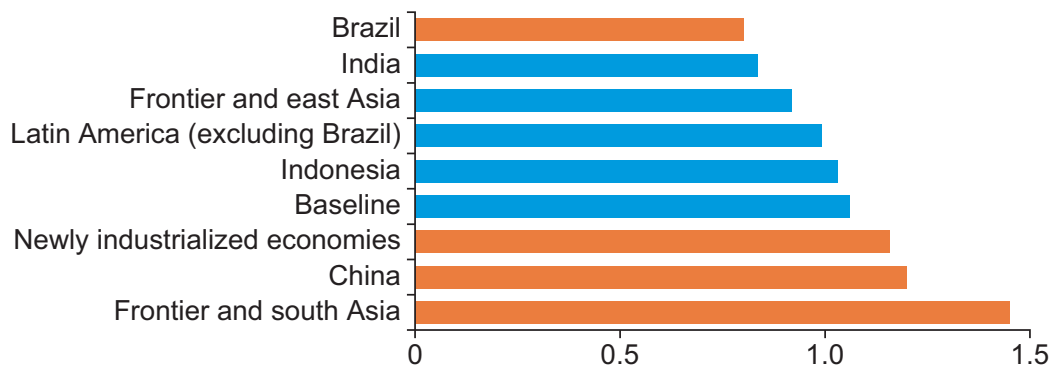

Figure 5.4 Degree of Inclusiveness of Growth

Sources: Penn World Tables; World Bank, PovcalNet; and IMF staff calculations.

Note: The red bars represent countries for which the estimated degree of inclusiveness is significantly different from one.

The figure shows impact on income of the top quintile, in percent, of a 1 percent increase in income per capita.

development-together with faster growth rates, on average, than in south Asia-has translated into bigger gains in poverty reduction and the incomes of the bottom quintile, even though growth has, on average, been relatively less pro-poor.

\section{FOSTERING INCLUSIVE GROWTH}

This section discusses policies that could reduce inequality and increase inclusiveness in frontier Asia, based on international experience and econometric evidence (see also Case Studies 5.1 and 5.2). ${ }^{12}$ The list of policies is not exhaustive, however, given that multiple factors behind rising inequality suggest that a set of mutually reinforcing policies will likely be needed and that the necessary mix will vary from country to country.

\section{Fiscal Policy}

Simple scatter plots point to an association between the degree of inclusiveness of growth and education and health (Figure 5.5, panels a and b). The relatively low share in GDP of spending on education and health across frontier Asia (especially south Asia) highlights an important potential role for fiscal policy in strengthening inclusiveness (Figure 5.5, panels $\mathrm{c}$ and $\mathrm{d}$ ).

Adjusting both the level and the structure of taxes and spending may have a part to play. In Organisation for Economic Co-operation and Development

\footnotetext{
${ }^{12}$ Other cross-country work finds that the labor share of income, public education spending, years of schooling, industry employment, and financial reform significantly increase the degree of inclusiveness (Balakrishnan, Steinberg, and Syed 2013). For Latin America, recent work has identified several factors that may have contributed to declining inequality, including policies aimed at enhancing employment and better distributing human capital through stepped-up provision of health and education services and conditional cash transfers (see ADB 2012, among others).
} 
a. Education and inclusiveness

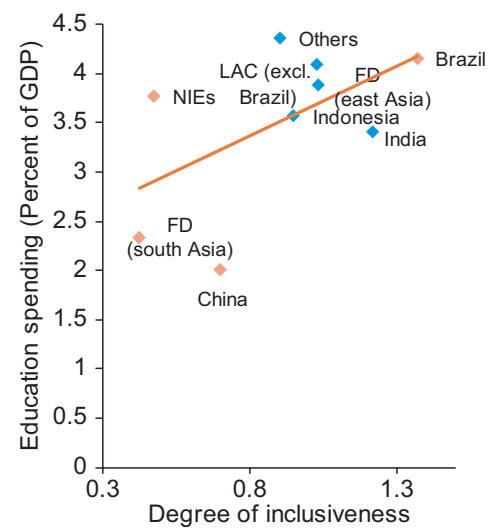

c. Public spending on education, total (Percent of GDP)

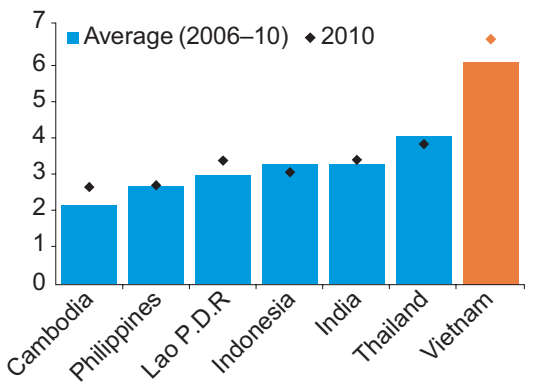

b. Health and inclusiveness

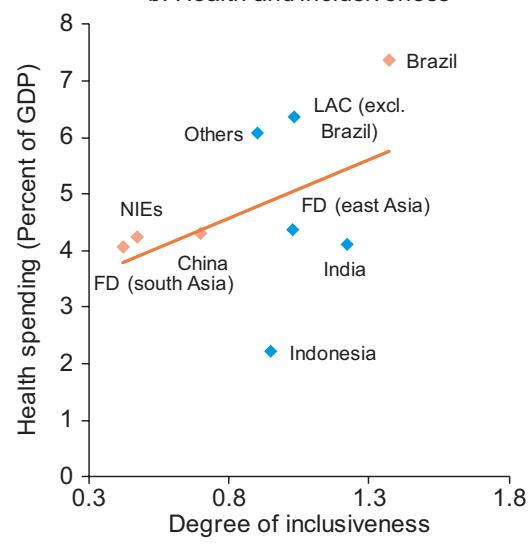

d. Health expenditure, public (Percent of GDP)

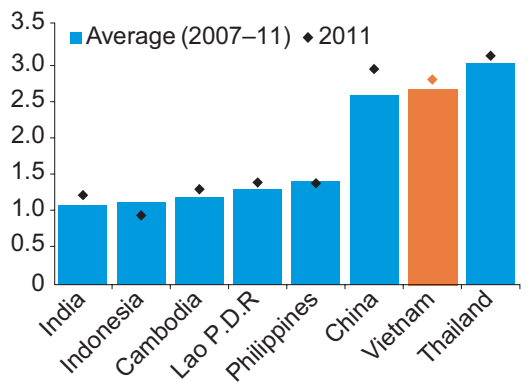

Figure 5.5 Fiscal Policy and Inclusiveness

Sources: World Bank, World Development Indicators; and IMF staff calculations.

Note: Red diamonds represent countries for which the estimated degree of inclusiveness is significantly different from one. FD = frontier and developing economies; LAC = Latin America and the Caribbean (excluding Brazil); NIEs = newly industrialized economies.

(OECD) countries, taxes and transfer policies have been estimated to reduce inequality as measured by the Gini index by about 25 percent (OECD 2012). In sharp contrast, the redistributive impact of fiscal policy in developing economies is severely restricted by lower overall levels of both taxes and transfers-average tax ratios for advanced economies exceed 30 percent of GDP, whereas taxes in Asian emerging market and frontier economies are only 19 percent of GDP as of the latest year for which data are available. This ratio is lower than the 30 percent in Latin America and 37 percent in emerging Europe (IMF 2013; Bastagli, Coady, and Gupta 2012).

Partly as a result, social spending is also substantially lower than the 15 percent of GDP it is in advanced economies. Public health and education spending in frontier Asia is in the 4-8 percent of GDP range, lower than for peers in other emerging market regions and little increased since 2000. 
Reliance on less progressive tax and spending instruments compounds the problem. In frontier Asia, income tax yields are lower than in peers and in advanced economies. Meanwhile, participation in social insurance schemes remains limited in many countries (particularly in rural areas), and expenditure on social assistance programs is often low and poorly targeted. According to ADB (2012), only about half the poor population in frontier Asia benefits from social programs.

It appears that raising tax revenue, and spending more efficiently and equitably, could help address income inequality in frontier Asia. On the tax side, efforts could focus on broadening income and consumption tax bases by reducing tax exemptions and improving compliance. On the spending side, measures could aim toward greater reliance on social expenditures, including on health and education, targeted to vulnerable households. In this regard, conditional cash transfer programs are being increasingly used in low-income emerging market economies, including Bangladesh and Cambodia. Brazil and Mexico have two of the largest schemes (in the former, Bolsa Familia covers about 25 percent of the population), with transfers contingent on requirements such as children's school attendance and vaccination records. Both are considered to have been successful, with the Mexican program associated with a 10 percent reduction in poverty within two years of its introduction. In Asia, the Philippines introduced a conditional cash transfer program in 2008 (the 4Ps) to help redirect resources toward socially desirable programs in a well-targeted way. ${ }^{13}$ In 2012, the 4Ps was budgeted to reach 60 percent of the poor, and by 2013 it was to cover 3.8 million households, with a cost to the budget of about 0.4 percent of GDP. In India, the recently launched unique identification scheme holds significant promise in ensuring better targeting of social programs and allowing the vulnerable to access the welfare system.

Enhancing other safety nets could also help. In particular, few frontier Asian economies have unemployment insurance schemes, and many have low pension coverage rates-less than 20 percent of the working-age population is covered in most of emerging Asia compared with an average of 60 percent in OECD countries (OECD 2009). Enhancing such safety nets, as well as increasing the inclusiveness of growth, would also reduce precautionary motives to save, thereby increasing consumption and facilitating global rebalancing.

A key question about such policies is their fiscal cost. The Bolsa Familia and 4Ps programs only cost 0.4 percent of GDP, and recent IMF work on China and Korea (Barnett and Brooks 2010; Feyzioglu, Skaarup, and Syed 2008) argues that a minimum social safety net can be provided at low cost, with more comprehensive safety nets funded by broadening the tax base and increasing some taxes, along with reallocating existing spending. For many economies, introducing (or increasing the rate of) a goods and services tax and reducing poorly targeted fuel subsidies would be obvious candidates. Some policies may have no government spending obligations, such as unemployment insurance schemes with employee and employer contributions to individual accounts. In many cases, the challenge

\footnotetext{
${ }^{13} 4$ Ps stands for Pantawid Pamilyang Pilipino Program.
} 
a. Employment laws ${ }^{1}$ and inclusiveness

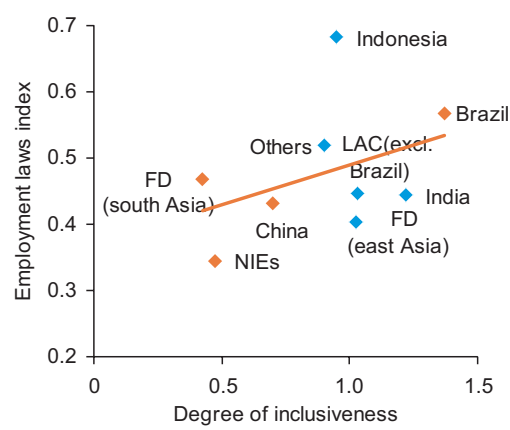

b. Minimum wage and inclusiveness

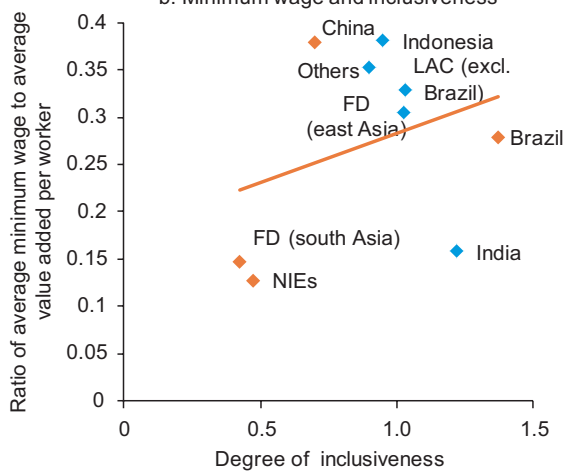

Figure 5.6 Labor Market Institutions and Inclusiveness

Sources: Botero and others (2004); World Bank, Doing Business database; and World Development Indicators database. Note: Red diamonds represent countries for which the estimated degree of inclusiveness is significantly different from one. FD = frontier and developing economies; LAC = Latin America and the Caribbean (excluding Brazil); NIEs = newly industrialized economies.

${ }^{1}$ Measures the protection of labor and employment laws as the average of: (1) Alternative employment contracts; (2) Cost of increasing hours worked; (3) Cost of firing workers; and (4) Dismissal procedures.

with regard to education is to improve quality. Expanding the provision of pensions could entail costs, but not necessarily if benefits are provided on a definedcontribution basis and contribution rates are increased.

\section{Labor Market Reform}

Simple scatter plots suggest that inclusiveness is positively associated with the degree of employment protection and minimum wage levels; frontier east Asia has relatively weak employment protection laws, and frontier south Asia has particularly low minimum wages (Figure 5.6).

These results are consistent with recent academic work on advanced economies that links rising inequality to weakened bargaining power of workers (for example, Levy and Temin 2007). Although a comprehensive discussion of the impact of labor market institutions (such as collective bargaining structures) on the inclusiveness of growth is beyond the scope of this chapter, addressing labor market duality and use of a minimum wage are increasingly advocated in the region to support incomes of low-wage workers. In addition, India has launched a program to guarantee a certain minimum level of employment in rural areas, which may have contributed to the slight decline in rural inequality observed there after 2005.

Minimum wage measures are one of the most well-studied policies, yet both theory and empirical evidence on their disemployment effects are largely ambiguous (Boeri and Van Ours 2008). Fine-tuning is often necessary: set the rate too low and it has no impact; set it too high and it will have significant disemployment effects. Moreover, minimum wages usually work better in combination with benefits conditional on employment because they reinforce each other. In particular, although employment-conditioned benefits may be a good way of

\section{(C) International Monetary Fund. Not for Redistribution}


providing targeted assistance and work incentives, if labor has a limited voice, employers could use such benefits to drive down wages, a situation a minimum wage can help prevent (Gregg 2000).

The labor share of income in frontier Asia has fallen as a result of both weak wage growth and the exceptionally low and declining employment intensity of its economic growth, particularly in south Asia. Potential explanations are increasing capital accumulation and high levels of surplus labor in many of these countries (ADB 2012). More income going to capital rather than to labor tends to increase inequality because capital is typically more unequally distributed than labor income. This tendency suggests that policies that lift the incomes of the poor are needed, such as eliminating any bias in the cost of capital and other inputs that favor capital, promoting labor-intensive sectors such as services, improving rural infrastructure to boost productivity in farming and increase job opportunities for the poor, and increasing household financial income by offering more diversifed and better-priced financial products, as discussed in the next subsection.

\section{Financial Inclusion}

The regression analysis indicates that financial reform increases the degree of inclusiveness of growth, suggesting the importance of reforms that enhance financial inclusion. The finding is in line with empirical literature that argues that financial development not only promotes economic growth, but can also help apportion it more evenly. According to some estimates, the benefits to the poorest quintile of financial development (see Chapter 6 on Financial Sector Deepening) are split roughly equally between those benefits attributable to faster growth and those attributable to greater income equality (Beck, Demirgüç-Kunt, and Levine 2007).

How does frontier Asia fare with respect to financial development? Disparity across the region is appreciable (Figure 5.7). Financial deepening - a measure of the level of financial services, typically proxied by the broad-money-to-GDP ratio-is positively associated with per capita income, although its rate of growth has generally been higher in frontier Asia, suggesting some catching up is taking place across the region (see Chapter 6).

In addition, deepening itself may not translate into financial services being broadly available across firms and households, making policies to promote access to finance equally important. Across the globe, high-income countries tend, on average, to have almost 12 times as many bank branches and 30 times as many automated teller machines for every 100,000 adults as do low-income countries. Lack of access to finance is a major impediment in many parts of frontier Asia, with nearly 60 percent of the population in east Asia and 80 percent in South Asia lacking access to the formal financial system (Table 5.4).

How might governments in frontier Asia promote financial development that both supports growth and reduces inequality? International experience provides some direction:

- Ensure macroeconomic stability as financial systems are liberalized, and particularly as they are opened up to the rest of the world. There is no one-size-fits-all 


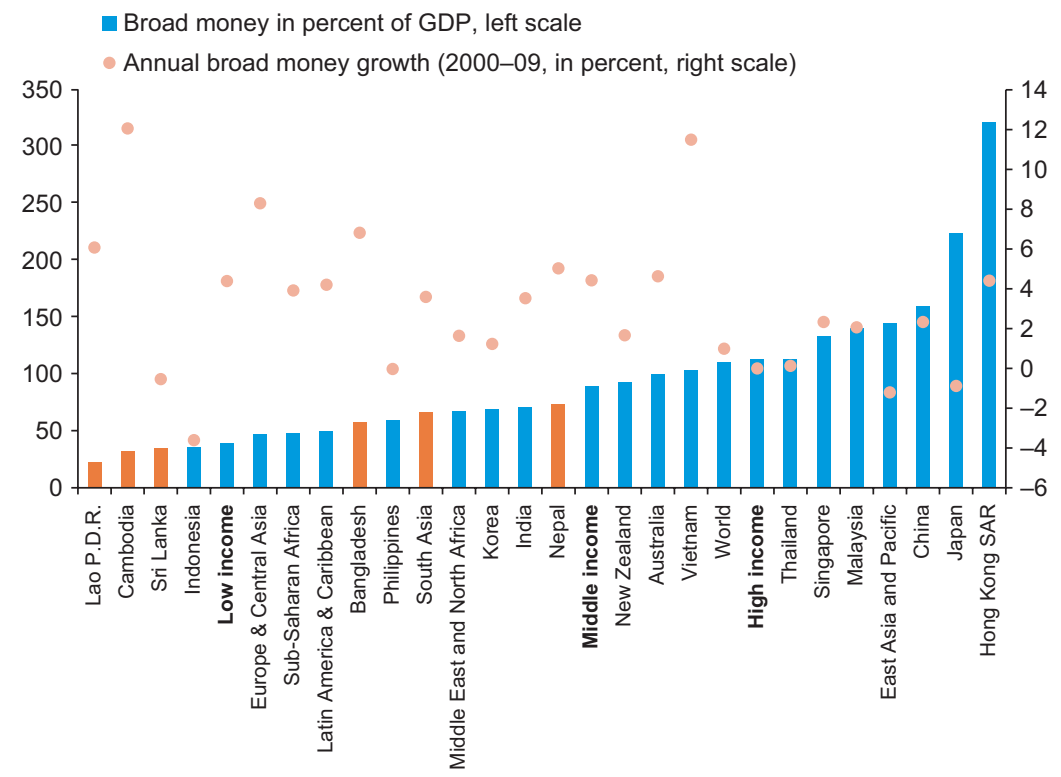

Figure 5.7 Financial Deepening (Latest year available)

Source: World Bank, World Development Indicators database; and IMF staff calculations.

\begin{tabular}{lccc}
\hline Selected Indicators of Financial Inclusion & & \\
\hline & $\begin{array}{c}\text { Households with } \\
\text { Access to Bank } \\
\text { (percent) }\end{array}$ & $\begin{array}{c}\text { Adult Population not Using } \\
\text { Formal Financial Services } \\
\text { (millions/percent) }\end{array}$ & $\begin{array}{c}\text { SMEs Lacking Access to Loan } \\
\text { from Financial Institution } \\
\text { (millions/percent) }\end{array}$ \\
\hline East Asia and Pacific & 42 & $876 / 51-75$ & $140-170 />59$ \\
South Asia & 22 & $612 / 51-75$ & $60-70 />59$ \\
Middle East and North Africa & 42 & $136 / 26-50$ & $12-15 />59$ \\
Sub-Saharan Africa & 12 & $326 / 75-100$ & $26-30 />59$ \\
Latin America and Caribbean & 40 & $250 / 51-75$ & $11-12 / 40-59$ \\
Central Asia and Eastern Europe & 50 & $193 / 26-50$ & $5-7 / 20-39$ \\
High-income countries & 92 & $60 / 0-25$ & $10-12 /<20$ \\
\hline
\end{tabular}

Sources: Consultative Group to Assist the Poor and World Bank (2010); and International Finance Corporation (2010). Note: SMEs = small and medium-sized enterprises.

approach to liberalizing financial systems; the process should be tailored to each country's circumstances. Across the world, prudently executed and sequenced reforms have resulted in greater flexibility in interest rates, improvements in credit allocation and risk management by commercial banks, deeper financial and capital markets, and significant enhancement in intermediation patterns. In tandem, the framework for monetary and exchange rate policy has typically undergone major changes, introducing market-based instruments to implement policy actions (see Chapter 9 on Monetary Policy Frameworks). The prudential framework and quality of 
supervision have also been strengthened to help prevent unsafe credit decisions and promote more effective management of market risks (see Chapter 7 on Financial Sector Vulnerabilities).

- Identify and remove impediments to access to finance-including those that inhibit competition - without directing particular outcomes. Notably, expanding credit availability by promoting rural finance; ensuring that regulations (such as loan classification criteria and capital requirements) do not discriminate against the provision of finance to the rural poor, including to the agricultural sector; strengthening creditor rights; extending microcredit; promoting credit information sharing; and developing venture capital markets should significantly expand credit availability (Beck and Demirgüç-Kunt 2006).

- In developing economies, harness new technologies to extend financial access to those previously excluded. Successful examples come from Kenya, where mobile phones have helped promote financial inclusion (IMF 2011), and India, whose unique identification program enables the poor to use their cell phones to perform banking functions while reducing transaction costs and facilitating trade. Technological innovation also has the potential to improve access to finance significantly, such as through the use of e-money and the provision of an efficient retail payments system.

- Bolster the legal environment and financial market infrastructure, including property rights and contract enforceability. For instance, a well-defined process for securing collateral in the event of default can encourage banks to lend more to small and medium-sized enterprises in developing economies.

- On the regulatory front, promote policies that foster transparency and competition among financial institutions (Levine 2012). Conversely, policies that channel credit to politically favored ends decrease the quality of financial services while increasing their cost and breeding corruption in credit allocation (see Barth and others 2009, for example). These distortions usually exert a disproportionately large impact on the living standards of lowerincome households.

\section{Governance}

Finally, institutional reforms can also play an important role in helping ensure that the gains from growth are widely shared. Work by Gupta, Davoodi, and Alonso-Terme (1998) suggests that high and rising corruption increases inequality and poverty, including by reducing the progressivity of the tax system, the level and effectiveness of social spending, and the formation of human capital. In resource-rich countries, potential reforms include reducing rent-seeking behavior through transparency initiatives and anticorruption efforts (Collier 2007). In addition, regulation or better enforcement of existing regulation can also help address failures in markets that the poor participate in-poorly functioning financial, land, and human capital markets—so that they also benefit from growth (Duflo 2012). 


\section{CASE STUDY 5.1 Bangladesh: On the Road to Inclusive Growth}

Bangladesh's experience illustrates the links between growth, poverty, and inequality in a populous, low-income frontier Asian economy. Despite its propensity for political upheaval and natural disaster, Bangladesh has achieved steady poverty reduction since 1990. From as high as 57 percent at the beginning of the 1990s, the headcount poverty rate declined to 31.5 percent in 2010, ${ }^{1}$ keeping Bangladesh well on track to reach Millennium Development Goal 1, to halve the proportion of people living below the poverty line by 2015 (Figure 5.1.1). Reinforcing the pro-poor nature of growth, inequality (as measured by the Gini coefficient of consumption) remained broadly stable during 2000-10, a decade during which Bangladesh experienced accelerating growth, after having picked up in the early 1990s. These advances were achieved in conjunction with improvements in a number of social indicators (Table 5.1.1), with Bangladesh standing out on several fronts when compared with the norms in the frontier south Asia region and low-income countries.

Several factors have contributed to Bangladesh's strong performance on poverty reduction since 1990. First, Bangladesh has seen sustained economic growth during the period, albeit not as rapid as that of the fastest-growing frontier Asian economies. Part of the growth in incomes was supported by rising worker remittances (more than 8 million Bangladeshis work abroad), which, in the latest period account for more than 11 percent of GDP, with attendant poverty-reducing benefits. Economic growth also translated into substantial improvements in rural income per capita. A key mechanism was the Green Revolution, which meant two crops (instead of one) a year could be grown on the same land. Because the highest incidence of poverty and the most extreme poverty tend to be rural (Figure 5.1.2), the Green Revolution helped make growth more pro-poor and inclusive, alongside the impressive poverty reduction in urban areas. ${ }^{2}$ Gains from rural poverty reduction were particularly evident during 2005-10, driven in part by greater policy attention to agriculture and rural development; the effects from the exogenous commodity food price increase, which raised real wages in the predominantly agricultural western regions; and in-migration from the western to the eastern divisions (thus reducing surplus rural labor supply).

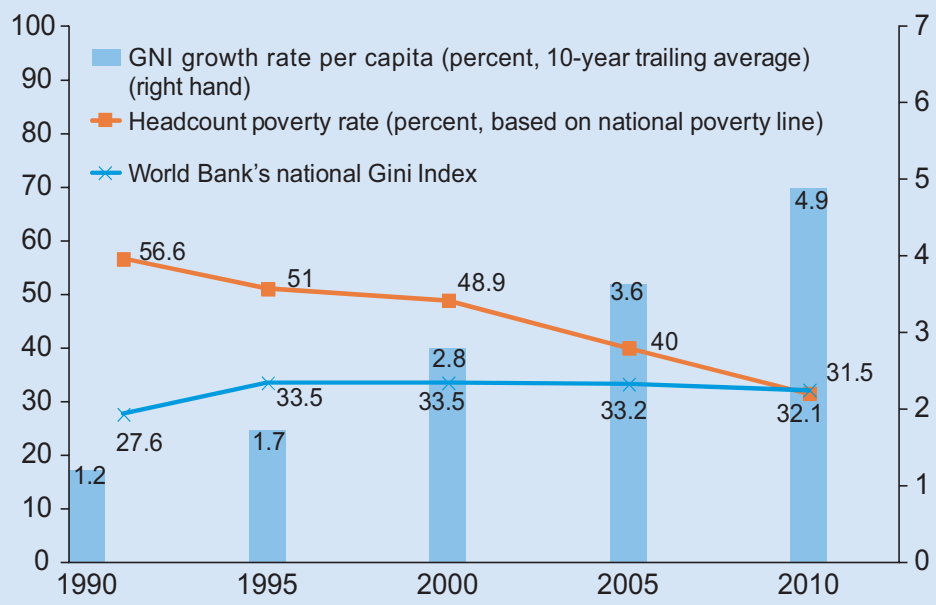

Figure 5.1.1 Bangladesh: Indicators of Growth, Poverty and Inequality Source: World Bank. Note: GNI = gross national income. 
CASE STUDY 5.1 Bangladesh: On the Road to Inclusive Growth (Continued)

TABLE 5.1.1 Bangladesh: Selected socio-development indicators (most recent available
estimate, 2005-2011)

\begin{tabular}{lccc}
\hline & Bangladesh & South Asia & Low Income Countries \\
\hline Gross national income per capita (Atlas method, US\$) & 780 & 1,176 & 528 \\
Population growth rate (\%) & 1.3 & 1.4 & 2.1 \\
Total fertility rate (births per woman) & 2.3 & 2.7 & 4.1 \\
Life expectancy at birth (years) & 67 & 65 & 59 \\
Infant mortality (per 1,000 live births) & 41 & 52 & 70 \\
Child malnutrition (\% of children under 5) & 41 & 33 & 23 \\
Adult literacy, male (\% of ages 15 and older) & 61 & 73 & 69 \\
Adult literacy, female (\% of ages 15 and older) & 51 & 50 & 54 \\
Net primary school enrolment, male (\% of age group) & 83 & 89 & 81 \\
Net primary school enrolment, female (\% of age group) & 90 & 84 & 78 \\
Access to an improved water source (\% of population) & 80 & 90 & 65 \\
Access to an improved sanitation (\% of population) & 56 & 38 & 37
\end{tabular}

Source: World Bank.

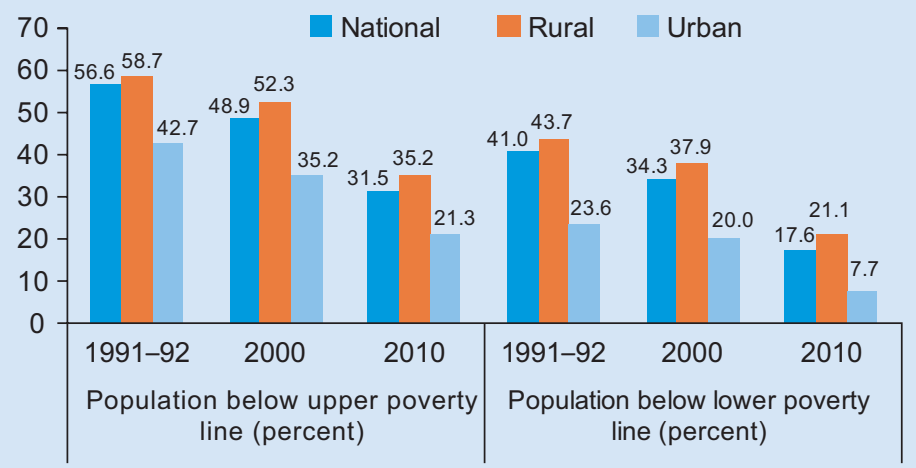

Figure 5.1.2 Bangladesh: Rural-Urban Poverty and Extreme Poverty Trends Sources: Bangladesh Bureau of Statistics, Household Income and Expenditure Survey 1991-92, 2000 and 2010.

Notes: Upper poverty line defined in monetary terms as an income less than will provide for 2,212 calories per day. Lower poverty line similarly defined to provide for 1,800 calories per day (also taken as a threshold for extreme poverty).

Second, the condition of women has improved significantly in Bangladesh throughout this period. Policies such as for microcredit have helped (Grameen Bank, an institution developed in Bangladesh, offers loans targeted mainly at women) as have family-planning programs introduced after Bangladesh's independence, which reduced fertility rates and raised the status of women within the household by giving them more influence over household size. The rise of the labor-intensive textile and garment industry, which has created almost 4 million jobs for unskilled and low-skilled workers-about 80 percent of them women - has also been a contributing factor.

Third, the government has maintained basic social spending programs, working in coordination with international and domestic development partners, including nongovernmental organizations. Relative to other south Asian countries, social safety net spending

(Continued)

\section{(C) International Monetary Fund. Not for Redistribution}




\section{CASE STUDY 5.1 Bangladesh: On the Road to Inclusive Growth (Continued)}

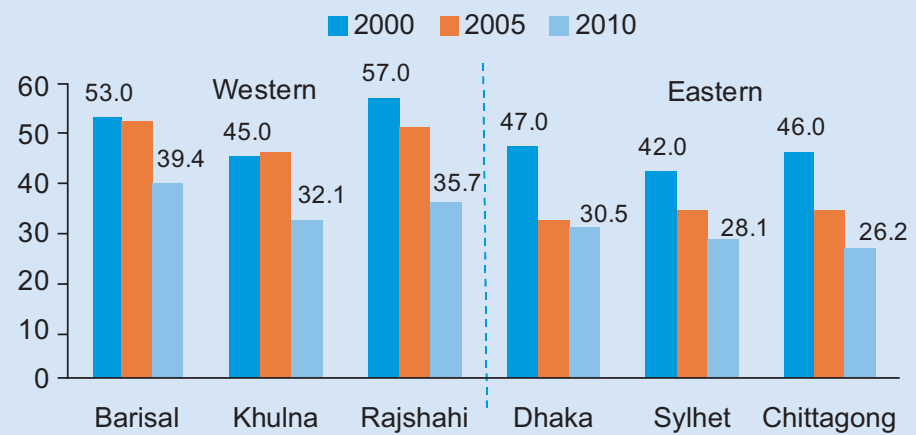

Figure 5.1.3 Bangladesh: Headcount Poverty of Divisions

Sources: Bangladesh Bureau of Statistics, Household Income and Expenditure Survey 2000, 2005, and 2010.

as a share of GDP in Bangladesh is comparable to that in India, but higher than in Nepal, Pakistan, and Sri Lanka (IMF 2012). ${ }^{3}$ These social safety net programs address poverty from a multifaceted perspective, including through education, health, nutrition, employment, and disaster response, and were estimated to have reached almost 40 percent of the poorest quintile based on Bangladesh's 2010 Household Income and Expenditure Survey. A major proportion of the support provided food assistance through direct feeding programs, followed by cash transfer social protection programs (including the flagship Employment Generation Program for the Poorest, which was set up in response to the 2008 food price crisis). The work of homegrown nongovernment organizations in Bangladesh has been another influential factor in poverty reduction, with a number of them (such as BRAC, now the largest nongovernment organization in the world) able to scale up operations since Bangladesh's independence in 1971 and work successfully in partnership with the government to support poverty reduction further.

Although favorable economic growth systematically helped reduce poverty, inequality rose until the mid-1990s as the country started to industrialize and urbanize. Since then, overall inequality trends have broadly stabilized, driven by some decline in urban inequality following rapid growth in the services sector in which many of the urban poor were employed (Paci and Sasin 2008). Nevertheless, inequality remains a pressing government concern, given that significant differences between geographic regions underlie the national poverty story, a phenomenon known as the "East-West divide" (World Bank 2008). The Dhaka, Sylhet, and Chittagong divisions in the eastern part of the country experienced rapid poverty reduction between 2000 and 2005 (Figure 5.1.3), but the gains were much smaller for Rajshahi in the west and almost nonexistent for Barisal and Khulna in the southwest. This pattern was partly reversed during 2005-10 when factors favoring rural incomes emerged, as noted previously. Addressing regional disparities remains a key thrust of Bangladesh's Sixth Five-Year Plan (fiscal years 2011-15) and reinforces the need for greater infrastructure connectivity for the economically isolated southwest divisions (exemplified by the government's centerpiece project for a bridge across the Padma River, which would connect those divisions with the economic heartland in the east, reducing transportation costs).

Notwithstanding its progress, Bangladesh remains a poor country, with almost 45 million people in poverty in 2010. Looking ahead, the challenge will be to further elevate the rate of economic growth to make even deeper reductions in poverty in 


\section{CASE STUDY 5.1 Bangladesh: On the Road to Inclusive Growth (Continued)}

Bangladesh, while taking care to preserve the characteristics that have supported inclusiveness in the growth process. Related to this, a key challenge is to reach the poor more effectively by improving the targeting of social safety nets, with the World Bank's work in Bangladesh on developing a poverty database a critical stepping stone toward this goal.

Source: Prepared by Seng Guan Toh.

${ }^{1}$ The headcount poverty rate based on Bangladesh's national poverty line (also known as the upper poverty line), defined in monetary terms as an income that provides for sufficient caloric intake based on the 2010 Household Income and Expenditure Survey, was about $\$ 1.22$ a day. The poverty headcount rate using the World Bank's $\$ 1.25$ a day (on a purchasing power parity basis as of 2005) shows a broadly similar declining trend since 1990 , from almost 70 percent of the population in the early 1990 s to 43.3 percent in 2010.

${ }^{2}$ Although urbanization has increased since 1990, Bangladesh remains largely rural, with about 72 percent of the population in rural areas in 2010 (as compared with 80 percent in 1990).

${ }^{3}$ Social safety net expenditures in the south Asian region ranged from about 0.8 percent of GDP in Sri Lanka to about 2 percent of GDP in Bangladesh and India (based on 2010-11 estimates).

\section{CASE STUDY 5.2 Vietnam: Poverty and Inequality}

Growth and inclusiveness: Since 1990, relatively robust growth in Vietnam has enabled an impressive halving of the incidence of extreme poverty, quite a substantial reduction when compared with other countries in the region and a key Millennium Development Goal achieved even before the 2015 target year. Moreover, growth has not resulted in increased inequality (Figure 5.2.1). The inclusive outcome also suggests that postreform growth in Vietnam has largely been pro-poor, buttressed by the provision of basic public services, access to land, and infrastructure investments that have reached the poorer segments of the population.

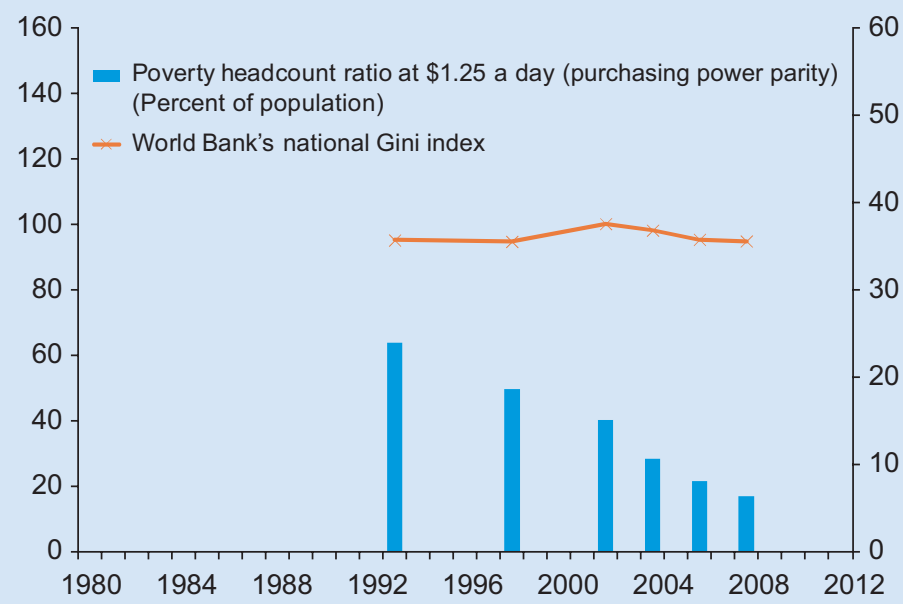

Figure 5.2.1 Vietnam's Poverty and Inequality

Source: World Bank, World Development Indicators database. 


\section{CASE STUDY 5.2 Vietnam: Poverty and Inequality (Continued)}

Challenges ahead: Despite remarkable progress, challenges remain because poverty reduction has become less responsive to economic growth. Even though rising education levels, diversification into nonfarm activities, and good coverage of local infrastructure and basic services have been powerful poverty-fighting forces during the past decade, the quality of these services is unevenly distributed. A World Bank report, which bases its findings on successive rounds of the Vietnam Household Living Standards Surveys (VHLSSlatest 2010), reveals that inequality in income and opportunity has started to rise, reflecting widening gaps between urban and rural dwellers and across the socioeconomic and ethnic spectrum (World Bank 2012).

Although educational attainment is increasing rapidly, enrollment gaps between poor and better-off households persist, perpetuating the intergenerational transmission of poverty as well as contributing to rising inequality. Based on an empirical model that uses VHLSS data, the recent increase in income inequality in part reflects (1) the altered relative return on education and on physical and financial assets and (2) inequalities in education and access to jobs and geographic disparities. Furthermore, as the birthrate declines and the population starts to age, the demographic dimension of the policy challenge has changed from the child poverty of the past to the rising risk of old-age poverty.

Policy focus: Based on cross-country experience, a number of policies could further the inclusiveness of growth in Vietnam. Vietnam's government has already focused higher shares of GDP on public health and education spending than have other countries in the region, but there is room for quality improvement and for more focus on youth in poor and ethnic minority areas. Fiscal policies that could sharpen these improvements include enhanced social safety nets-for example, increases in pension coverage and conditional cash transfers. Expanded basic financial services and improved financial system governance could also go a long way toward improving inclusiveness. Finally, policies to lift the incomes of the poor in Vietnam could include improving rural infrastructure to boost farm productivity and job opportunities, as well as eliminating distortions in the cost of, and access to, capital and land, which spur overinvestment and could undermine laborintensive sectors such as services and small and medium-sized enterprises.

Source: Prepared by Ashvin Ahuja.

\section{CONCLUSION}

This chapter assesses the extent to which frontier Asia's recent growth has been pro-poor and inclusive compared with its own history and compared with other emerging markets and the factors driving these outcomes. Although poverty has fallen across the region since 1990, inequality has increased in most of the economies, dampening the impact of growth on poverty reduction. As a result, relative to other regions and to frontier Asia's own past, the recent period of growth has generally been both less inclusive and less pro-poor, the latter in the sense that more gains in poverty reduction could have been possible given the region's economic growth rates. More specifically, some of the key results include the following: 
- In frontier Asia, growth has been highly pro-poor. In frontier south Asia, income growth has had the highest impact on poverty reduction among all emerging market regions.

- However, past increases in inequality in frontier Asia are likely to reduce the future impact of income growth on poverty, even if policymakers can somehow stem the tide and keep the level of inequality from worsening.

- Moreover, the relatively sharp increase in inequality means that growth has generally not been inclusive in frontier south Asia, nor for China and the NIEs. However, growth has been inclusive in frontier east Asia, and strongly so in Brazil. It is important to note though that inequality—as measured by the Gini coefficient-remains lower in frontier south Asia than in many other regions.

- Economic growth is still a key driver of poverty reduction-although growth in recent decades has been more pro-poor in south Asia, overall growth rates have, on average, been higher in frontier east Asia. These higher growth rates, together with relatively lower increases in inequality, have translated into greater poverty reduction and greater increases in the incomes of the bottom quintile.

Based on cross-country experience and other qualitative considerations, a number of policies could help redress the recent period of less inclusive and less pro-poor growth in frontier Asia. Fiscal policies could include higher spending on health and education and enhanced social safety nets (for example, increases in pension coverage and conditional cash transfers). Greater attention must also be paid to labor market reforms that increase the voice of labor (for example, minimum wages and reducing duality in labor contracts), thereby boosting labor's share in total income. Finally, building a more inclusive financial system and improving governance should also be part of the policy package.

\section{REFERENCES}

Asian Development Bank (ADB). 2012. Outlook 2012: Confronting Rising Inequality in Asia. Manila.

Balakrishnan, R., C. Steinberg, and M. Syed. 2013. "The Elusive Quest for Inclusive Growth: Growth, Poverty, and Inequality in Asia." IMF Working Paper 13/152, International Monetary Fund, Washington.

Barnett, S., and S. Brooks. 2010. "China: Does Government Health and Education Spending Boost Consumption?” IMF Working Paper 10/16, International Monetary Fund, Washington.

Barth, J. R., C. Lin, P. Lin, and F. M. Song. 2009. "Corruption in Bank Lending to Firms: Cross-Country Evidence on the Beneficial Role of Competition and Information Sharing." Journal of Financial Economics 91: 361-88.

Bastagli, F., D. Coady, and S. Gupta. 2012. "Income Inequality and Fiscal Policy." IMF Staff Discussion Note 12/08, International Monetary Fund, Washington.

Beck, T. H. L., and A. Demirgüç-Kunt. 2006. "Small and Medium-Size Enterprises: Access to Finance as a Growth Constraint." Journal of Banking and Finance 30 (11): 2931-43.

Beck, T. H. L., and R. Levine. 2007. "Finance, Inequality and the Poor." Journal of Economic Growth 12 (1): 27-49. 
Boeri, T., and J. Van Ours. 2008. The Economics of Imperfect Labor Markets. Princeton, New Jersey: Princeton University Press.

Botero, J., S. Djankov, R. Porta, F. Lopez-De-Silanes, and A. Shleifer. 2004. "The Regulation of Labor." Quarterly Journal of Economics 119 (4): 1339-82.

Collier, Paul. 2007. The Bottom Billion: Why the Poorest Countries Are Failing and What Can Be Done about It, Oxford: Oxford University Press.

Consultative Group to Assist the Poor (CGAP) and World Bank. 2010. Financial Access 2010: The State of Financial Inclusion through the Crisis. Washington: World Bank.

Dollar, D., and A. Kraay. 2002. "Growth Is Good for the Poor." Journal of Economic Growth 7 (3): $195-225$.

Duflo, Esther. 2012. "Balancing Growth with Equity: The View from Development." Unpublished, Massachusetts Institute of Technology, Department of Economics, Cambridge, Massachusetts.

Feyzioglu, T., M. Skaarup, and M. Syed. 2008. "Addressing Korea’s Long-Term Fiscal Challenges." IMF Working Paper 08/27, International Monetary Fund, Washington.

Government of Bangladesh Planning Commission. 2011. "Sixth Five-Year Plan of Bangladesh, FY2011-2015: Accelerating Growth and Reducing Poverty.” Dhaka.

Gregg, P. 2000. "The Use of Wage Floors as Policy Tools." Economic Study No. 31, Organisation for Economic Co-operation and Development Publishing, Paris.

Gupta, S., H. Davoodi, and R. Alonso-Terme. 1998. "Does Corruption Affect Income Inequality and Poverty?” IMF Working Paper 98/76, International Monetary Fund Washington.

International Finance Corporation (IFC). 2010. "Access to Finance: Annual Review Report." Washington.

International Monetary Fund (IMF). 2006 (September). "Rising Inequality and Polarization in Asia." In Regional Economic Outlook: Asia and Pacific. Washington.

_ 2011 (October). "How Inclusive Has Africa’s Recent High-Growth Episode Been?" In Regional Economic Outlook: Sub-Saharan Africa. Washington.

_ 2012. "Bangladesh: Request for a Three-Year Arrangement under the Extended Credit Facility, Annex I: Macroeconomic Adjustment with a Human Face: Public Social Safety Nets in Bangladesh.” IMF Country Report 12/94, Washington.

—. 2013 (April). "Fiscal Policy: Dampening Cyclical Fluctuations and Supporting Inclusive Growth." In Regional Economic Outlook: Asia and Pacific. Washington.

Jaumotte, F., S. Lall, and C. Papageorgiou. 2008. "Rising Income Inequality: Technology, or Trade and Financial Globalization.” IMF Working Paper 08/185, International Monetary Fund, Washington.

Levine, R. 2012. "Finance, Regulation and Inclusive Growth." In Promoting Inclusive Growth: Challenges and Policies. Paris: Organisation for Economic Co-operation and Development.

Levy, F. S., and P. Temin. 2007. "Inequality and Institutions in 20th Century America." Working Paper 07-17, Massachusetts Institute of Technology, Department of Economics, Cambridge, Massachusetts.

Milanovic, Branko. 2010. "Poverty and Inequality." World Bank, Washington. http://econ .worldbank.org/WBSITE/EXTERNAL/EXTDEC/EXTRESEARCH/EXTPROGRAMS /EXTPOVRES/0,,contentMDK:23022308 menuPK:8322745 pagePK:64168182 piPK:64 168060 -theSitePK:477894,00.html.

Organisation for Economic Co-operation and Development (OECD). 2009. Pensions at a Glance, Special Edition: Asia/Pacific. Paris.

- 2012. "Income Inequality and Growth: The Role of Taxes and Transfers." Economics Department Policy Note 9. Paris.

Paci, P., and M. Sasin. 2008. Making Work Pay in Bangladesh: Employment, Growth and Poverty Reduction. Washington: World Bank. 
Rauniyar, G., and R. Kanbur. 2010. "Inclusive Development: Two Papers on Conceptualization, Application, and the ADB Perspective." Asian Development Bank, Manila.

Ravallion, M., and S. Chen. 1997. "What Can New Survey Data Tell Us about Recent Changes in Distribution and Poverty?” World Bank Economic Review 11 (2): 357-82. . 2003. "Measuring Pro-Poor Growth." World Bank Policy Research Working Paper 2666, World Bank, Washington.

World Bank. 2008. "Bangladesh—Poverty Assessment for Bangladesh: Creating Opportunities and Bridging the East-West Divide." Report 44321-BD, Washington.

. 2012. Well Begun, Not Yet Done: Vietnam's Remarkable Progress on Poverty Reduction and the Emerging Challenges. Washington.

_- 2013a. World Development Indicators database. http://data.worldbank.org/ data-catalog/world-development-indicators.

2013b. Doing Business database. http://www.doingbusiness.org/data. 
This page intentionally left blank

CInternational Monetary Fund. Not for Redistribution 


\section{Strengthening Policy Frameworks}

CInternational Monetary Fund. Not for Redistribution 
This page intentionally left blank

CInternational Monetary Fund. Not for Redistribution 


\section{Financial Sector Deepening and Transformation}

\section{ERA Dabla-NorRIS, YASUHISA OJIMA, AND Marco ARena}

Financial deepening is a multidimensional concept. It can be viewed as the process of enhancing and broadening financial systems by increasing the depth, liquidity, efficiency, and volumes of financial institutions and markets, as well as diversifying of domestic sources of finance and extending access to banking and other financial services.

Countries in frontier and developing Asia $^{1}$ have implemented significant financial reforms during the past decades, including financial market liberalization, bank privatization, and efforts to build the capacity of central banks and financial authorities to conduct prudential regulation and supervision of the financial system. As a result, coupled with macroeconomic stability and growth and favorable global conditions, financial systems in frontier and developing Asia have grown and inclusion has broadened. Still, most systems remain small and relatively undiversified, and access to financing for much of the population is limited, which suggests considerable scope for further deepening

Well-managed financial deepening in frontier and developing Asia can enhance macroeconomic stability by increasing resilience to external shocks and helping promote and sustain inclusive economic growth (see also Chapter 5 on Inclusive Growth). However, the deepening itself can create new risks that need to be effectively managed (see Chapter 7 on Financial Sector Vulnerabilities). This chapter addresses the following questions: Why does financial deepening matter for frontier and developing Asia? What is the current state of play? How can sustainable financial deepening best be promoted? ${ }^{2}$

\section{WHY FINANCIAL DEEPENING MATTERS}

Limited financial system depth and breadth can pose challenges for maintaining macro-financial stability, managing macroeconomic volatility, and promoting inclusive growth. This section sheds light on the benefits of financial deepening

\footnotetext{
${ }^{1}$ Frontier and developing Asia in this chapter refers to 11 countries: Bangladesh, Bhutan, Cambodia, Lao P.D.R., Maldives, Mongolia, Myanmar, Nepal, Papua New Guinea, Timor-Leste, and Vietnam.

${ }^{2}$ This chapter draws on the analysis in IMF (2012).
} 
for frontier and developing Asia, focusing on its links to growth, poverty, inequality, and macroeconomic volatility.

\section{Growth, Poverty, and Inequality}

Financial system development and economic growth influence each other positively. A significant body of empirical research suggests that financial development drives economic growth (Levine 2005; Levine, Loayza, and Beck 2000). Financial development enables larger investments, including in much-needed infrastructure, and a more productive allocation of capital, leading to higher economic growth. In the absence of well-developed and inclusive financial systems, individuals must rely on their limited savings to invest in their education or become entrepreneurs, and small enterprises must rely on their limited earnings to pursue growth opportunities. Slower and less inclusive economic growth will result. At the same time, financial system development can be viewed as a byproduct of economic expansion, which creates wealth and opportunities that, in turn, provide the impetus to enlarge and further develop the financial system.

But the benefits of financial deepening extend beyond financing investment and include better and cheaper services for savings and making payments. These services allow firms and households to reduce transaction costs and provide the opportunity to accumulate assets and smooth income, thus reducing poverty and inequality. These issues are of concern to policymakers in frontier and developing Asia given still-high poverty levels, almost double those in emerging market Asian countries (Table 6.1). Evidence suggests that financial development can reduce income inequality by boosting the growth rate of the income share of the poorest quintile. Studies find that about 40 percent of the impact of financial development on the income growth of the poorest quintile results from a reduction in income inequality (Beck, Demirgüç-Kunt, and Levine 2007). ${ }^{3}$ Financial development is also strongly associated with poverty alleviation across the world. It has been found to lead to faster reduction in the percentage of the population living on less than $\$ 1$ a day. ${ }^{4}$

\section{Macroeconomic Volatility}

Deeper and more diversified financial systems can help strengthen an economy's resilience and capacity to cope with shocks and mitigate macroeconomic volatility through different channels (Figure 6.1). ${ }^{5}$ Deep financial systems can alleviate

\footnotetext{
${ }^{3}$ This sheds light on the distribution channel of financial development. They also find that the channel is the strongest among rich countries.

${ }^{4}$ For instance, Honohan (2004) finds that financial depth is negatively associated with headcount poverty, even after taking account of mean income and inequality.

${ }^{5}$ Research suggests that countries with more developed financial systems experience smaller fluctuations in real per capita output, consumption, and investment growth over the medium term. The empirical analysis also points to a U-shaped relationship between financial depth and volatility, with higher financial depth exacerbating volatility at levels observed in many advanced economies (DablaNorris and Narapong, 2013).
} 


\begin{tabular}{|c|c|c|}
\hline \multicolumn{3}{|c|}{ Poverty Level in Emerging Market Asia and Frontier and Developing Asia } \\
\hline & Frontier and Developing Asia ${ }^{1}$ & Emerging Market Asia \\
\hline Median (\% of population) & 24.8 & 13.1 \\
\hline Average (\% of population) & 27.0 & 12.9 \\
\hline
\end{tabular}

Source: World Bank, World Development Indicators, latest available numbers per country.

Note: Poverty headcount ratio at $\$ 1.25$ a day (purchasing power parity, percent of population).

${ }^{1}$ Bangladesh, Bhutan, Cambodia, Lao P.D.R., Nepal, Timor-Leste, Vietnam.

${ }^{2}$ China, India, Indonesia, Malaysia, Philippines, Sri Lanka, Thailand.

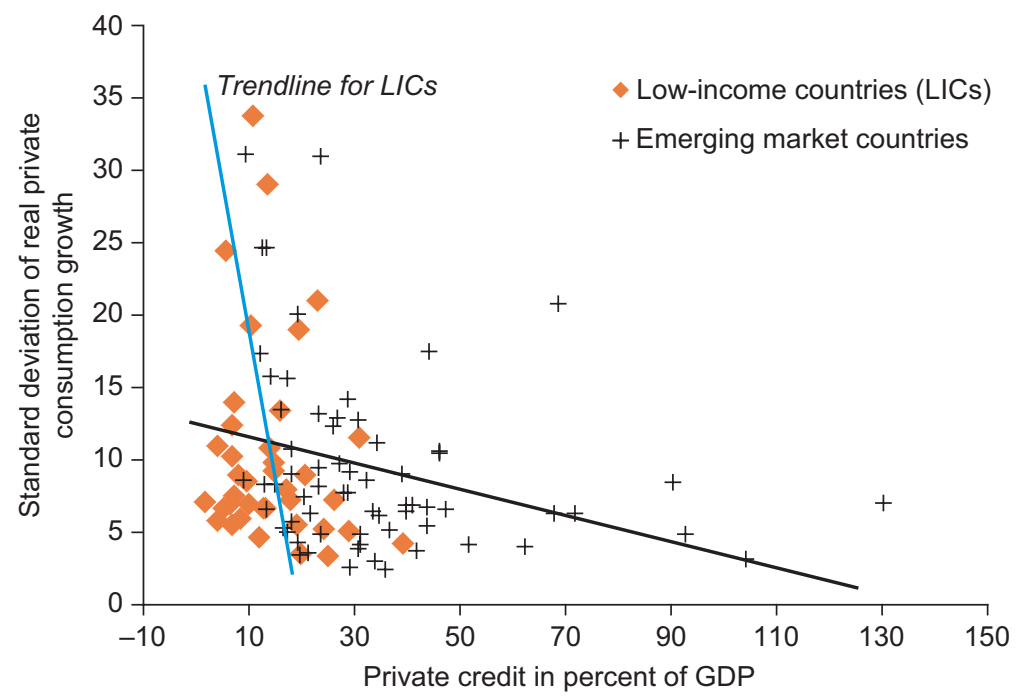

Figure 6.1 Financial Development and Consumption Volatility, 1980-2009

Sources: IMF staff calculations and World Economic Outlook database.

liquidity constraints on firms and industries, thus reducing the volatility of investment and output. Similarly, access to insurance arrangements and saving opportunities allow households to better smooth consumption intertemporally. Shallow financial systems in frontier and developing economies can limit fiscal, monetary, and exchange rate policy choices; hamper macroeconomic policy transmission; and impede opportunities for hedging or diversifying risk (IMF 2012). This is of particular concern because many countries in frontier and developing Asia are vulnerable to external shocks, such as sharp swings in the terms of trade, fluctuations in external demand, natural disasters, and volatile external financing.

\section{Enhancing macroeconomic policy effectiveness}

Shallow financial systems can constrain a country's choice of macroeconomic policy regimes (such as exchange rate and monetary regimes) and the effectiveness of fiscal policy. Furthermore, feedback loops may occur: policy stances can 

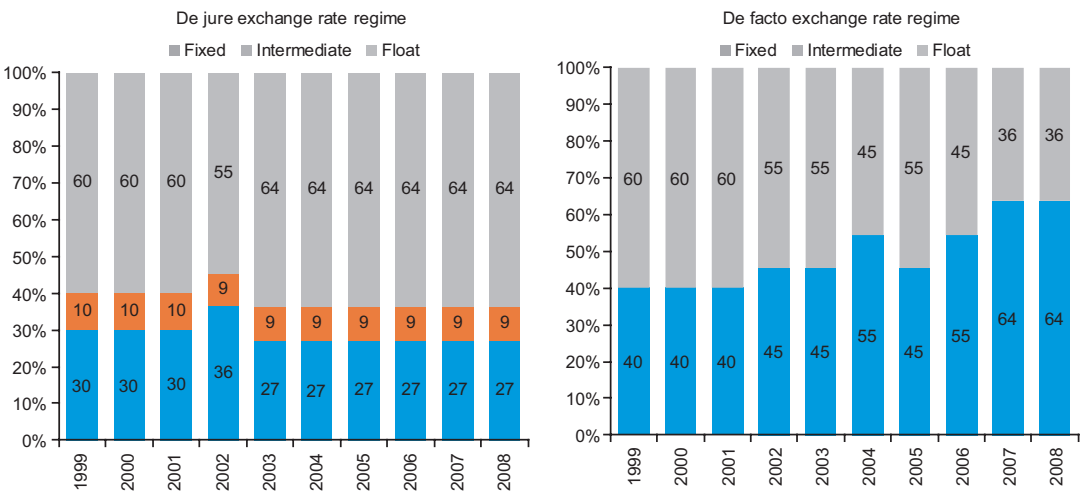

Figure 6.2 Exchange Rate Regime in Frontier and Developing Asia

Source: IMF, Annual Report on Exchange Arrangements and Exchange Restrictions.

themselves affect financial deepening (for example, exchange rate flexibility can foster creation of new products and expertise in foreign exchange markets). Moreover, the scope for maintaining macroeconomic stability and implementing countervailing policies in the event of external shocks is constrained by underdeveloped financial systems.

- Exchange rate regime: $\mathrm{A}$ country's choice of exchange rate regime reflects a variety of considerations, but financial underdevelopment can constrain the available options. Research has shown that financial depth has a significant impact on a country's choice of exchange rate regime, with less financially developed countries more likely to choose pegs (Obstfeld and Taylor 2004; Lin and Ye 2011). ${ }^{6}$ Almost two-thirds of frontier and developing Asian economies have de facto fixed regimes (Figure 6.2; also see Chapter 9 on Monetary Policy Frameworks). However, exchange rate flexibility can also pose challenges in the absence of deep financial markets, fueling exchange rate and output volatility, with the attendant costs for stability and growth. These effects can be particularly pronounced for natural-resource-based economies subject to high terms-of-trade and real exchange rate volatility.

- Monetary policy: Both the choice of instruments for monetary policy implementation and the efficacy of the transmission mechanism in combating inflation are related to a country's level of financial development. For instance, although indirect instruments are increasingly prevalent, frontier and developing Asian countries, like other low-income countries, are more likely to use direct instruments (such as interest rate and credit controls) than are advanced economies or emerging markets. Frontier and developing

\footnotetext{
${ }^{6} \mathrm{Lin}$ and $\mathrm{Ye}(2011)$ find that this effect is large: a one standard deviation increase in the measure of financial development leads to a 20 percentage point decline in the probability of choosing a fixed exchange regime. They also find that the more developed a country's financial markets are, the more likely it is to exit from a fixed exchange rate regime.
} 


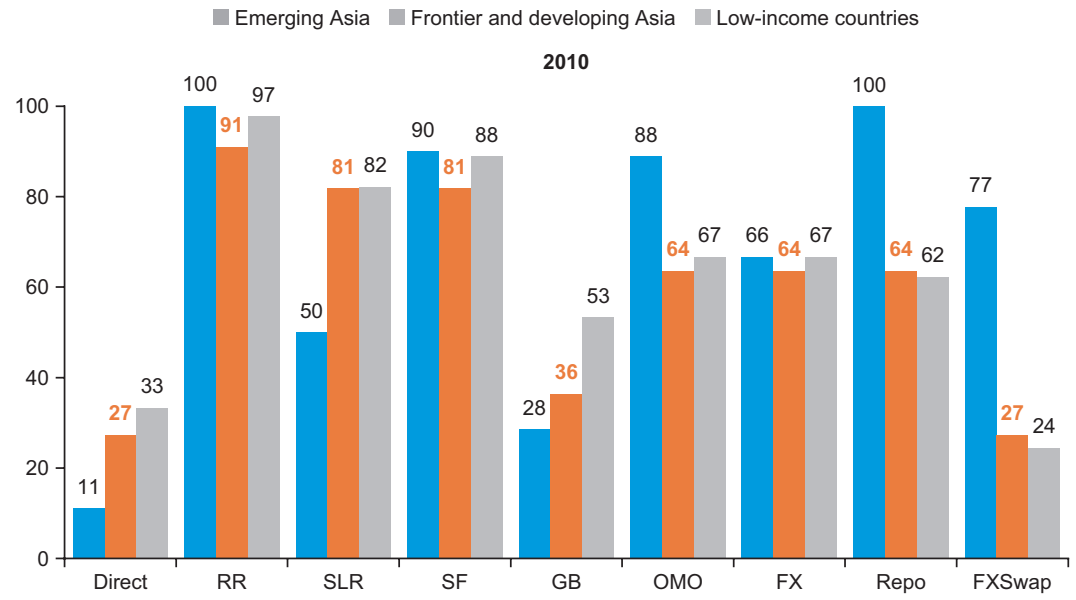

Figure 6.3 Use of Monetary Policy Instruments (By income group)

Sources: IMF, Information System for Instruments of Monetary Policy (ISIMP), a database containing the results of a biannual survey of monetary policy instruments covering 140 countries. See also IMF (2012).

Notes: Direct $=$ direct controls; $F X=$ foreign exchange; $F X$ swap = foreign exchange swaps; $G B=$ operations in government bond markets; $\mathrm{OMO}=$ open market operations; Repo = repurchase operations; $\mathrm{RR}=$ reserve requirement; $\mathrm{SF}=$ standing facilities; SLR = statutory liquidity requirements.

Asian countries are also more likely to rely on direct controls and statutory liquidity ratios as opposed to market-based instruments (such as secondary market operations-Figure 6.3). Pervasive excess liquidity in the banking system (which puts all banks on the sell side of money markets) in some frontier and developing Asian economies_-and thin credit and government securities markets-limit the influence of policy rates, undermining policy transmission. Moreover, although shallow markets may not preclude the adoption of monetary frameworks such as inflation targeting, they render their operation more challenging.

- Fiscal policy: Deep and diversified financial markets ensure more stable sources of government financing and can create an enabling environment for fiscal consolidation. In instances in which thin domestic debt markets and variable foreign financing leave little room to maneuver, fiscal policy itself can amplify the impact of shocks, fueling volatility. The lack of financial market depth can also constrain fiscal policy in a way that hinders the implementation of countercyclical fiscal policy prescriptions (Figure 6.4). For instance, budget deficits and higher government borrowing can amplify private sector crowding-out effects when financial markets are shallow.

\section{Managing capital flows}

Frontier and developing Asian economies have become substantially more financially integrated internationally since 1990. De facto financial globalizationmeasured by gross external assets and liabilities as a percent of GDP_has almost 


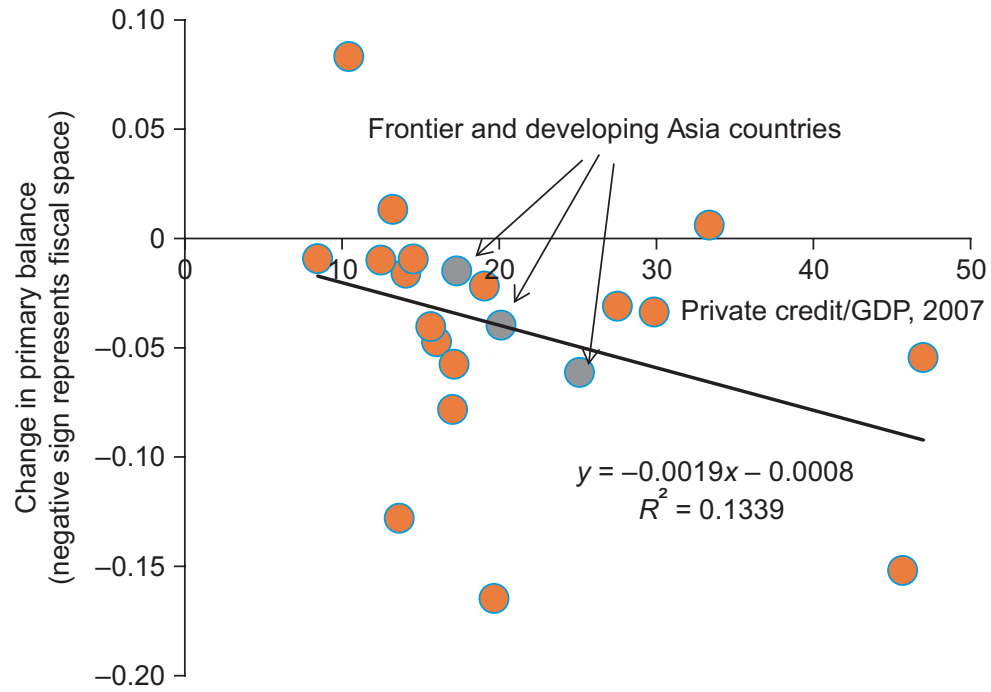

Figure 6.4 Countercyclical Fiscal Policies in Low-Income Country and Financial Development (Change between 2007-09)

Sources: IMF, World Economic Outlook database; and World Bank.

doubled since the mid-1990s (Figure 6.5). A high degree of financial integration can confer significant benefits in economic growth and risk sharing, and even help develop the financial sector and deepen capital markets. However, the volatility of capital inflows can create challenges for macroeconomic and prudential policy. Although frontier and developing Asian economies are relatively less open financially than many emerging market Asian economies, these issues are likely to become more pressing as countries liberalize their capital accounts. Lack of depth in local banking and financial markets has been found to increase the risks associated with large capital flows. ${ }^{7}$ Shallower markets allocate capital less efficiently, potentially contributing to boom-bust cycles in credit, investment, and the broader economy. They also, by definition, have a lower capacity to absorb inflows without large changes in asset prices and real exchange rates (FSB, IMF, and World Bank 2011).

\section{Financial stability}

Financial systems in frontier and developing Asia are less interconnected than systems in more mature economies, which explain, in part, their resilience to the global financial crisis. But the absence or illiquidity of markets can still expose them to potentially large shocks and instability and complicate risk management. ${ }^{8}$

\footnotetext{
${ }^{7}$ It is important to acknowledge that the deeper domestic bond markets in emerging markets (Brazil, South Africa, Turkey, and so on) also experienced the greatest volatility during summer 2013 .

${ }^{8}$ Remember that there are risks stemming from financial deepening (such as excessive credit growth and non-deposit-financed credit expansion).
} 


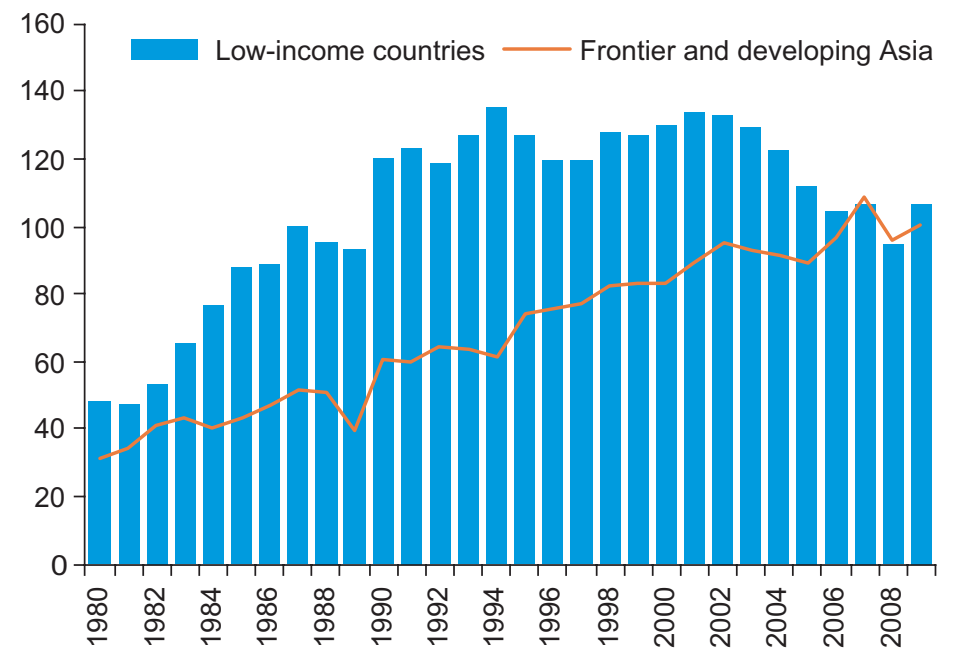

Figure 6.5 Financial Globalization, 1980-2009 (Percent of GDP)

Source: Lane and Milesi-Ferretti (2010).

Note: Financial globalization is sum of gross external assets and liabilities.

- Foreign currency risk: Realized risks to market participants are higher in underdeveloped financial systems. Although some countries in frontier and developing Asia have markets for currency forwards (Bangladesh, Vietnam), they remain relatively rare. Absent currency forwards, other derivatives or natural hedges and direct (through net open positions) and indirect (resulting from credit in foreign currency to domestic borrowers) exposure of financial institutions increases vulnerability to currency risk, particularly in dollarized economies (Cambodia, Timor-Leste). Credit risk is also heightened because borrowers who experience currency mismatches on their balance sheets are more vulnerable to unexpected exchange rate fluctuations.

- Liquidity management: Shallow financial markets can complicate liquidity management in financial institutions. For instance, thin domestic money markets increase the costs to banks of adjusting their liquidity positions and managing their portfolios. These potential costs help explain why banks in frontier and developing countries maintain relatively high proportions of liquid assets to meet sudden or unexpected obligations (such as a liquidity ratio exceeding 60 percent in Papua New Guinea)—another contributor to higher costs. Furthermore, short and uncertain liabilities constrain asset maturities, reducing banks' ability to withstand shocks and more easily transmitting financial shocks to the broader economy.

\footnotetext{
${ }^{9}$ In Cambodia, for instance, where dollar deposits at banks are only partially covered by liquid dollar assets, banks are exposed not only to foreign exchange risk, but also to liquidity risk. Similarly, in Mongolia, about a third of deposits are denominated in foreign currency, adding to liquidity pressures (IMF 2012).
} 
- Concentration risks and resource allocation: The narrow range of formal actors and economic activity, coupled with minimal scope for diversification in shallow markets, leads to a concentration of banks' exposures to a limited number of counterparties. This concentration amplifies attendant credit and interest rate risks and can exert pressure on bank profitability and solvency if external factors deteriorate (such as during an economic downturn or the default of a large customer). Historically, concentration of credit risks in bank loan portfolios has been one of the major sources of bank distress in frontier and developing economies.

\section{CURRENT STATE OF FINANCIAL DEEPENING}

\section{Stylized Facts}

The environment in which frontier and developing Asian economies' financial systems operate has changed radically since 1990 . Better policy and economic management and implementation of wide-ranging financial sector reformscombined with a favorable external environment in the run-up to the global financial crisis and ample global liquidity-have fostered financial sector development.

This section takes stock of recent trends in financial deepening in frontier and developing Asia and assesses whether these trends are in line with relevant comparators-Asian emerging market economies and other frontier and developing economies. ${ }^{10}$

Financial systems in frontier and developing Asia remain largely bank based. One indicator of financial structure, proxied by the ratio of stock market capitalization to private credit, shows the larger weight of the banking sector relative to markets in the median frontier and developing Asian economy, particularly in comparison with emerging market Asia (Figure 6.6A, panel 1). This also suggests that banks are the main players in the chain of payments and financial markets, including money and foreign exchange markets. This is not surprising given that relationship-based systems - via financial intermediation through banks - tend to prevail at early stages of financial development. ${ }^{11}$ As financial systems develop, however, they tend to move toward activities favoring more arm's-length transactions.

\footnotetext{
${ }^{10}$ Although the concept of financial deepening is defined through services provided to the economy, it is measured using quantitative indicators referring to the size, efficiency, liquidity, and reach of financial systems. These indicators are usually specific to different segments of the financial sector that specialize in the provision of different financial services.

${ }^{11}$ Bank-based systems can have a comparative advantage in reducing market friction associated with asymmetric information and immature legal systems because banks may produce private information and may valuate assets as collateral for their lending, drawing on their relationships (Rajan and Zingales 2001).
} 


\section{A. Banking size}

1. Stock market capitalization over private credit (Percent)

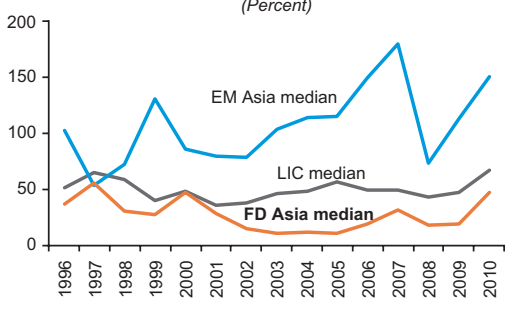

Source: Authors' estimations based on FinStat database and Demirgüç-Kunt and others (2010) data set.

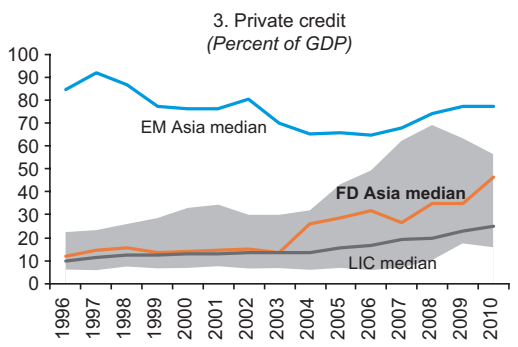

Source: Authors' estimations based on FinStat dababase and Demirgüç-Kunt and others (2010) data set.

Note: Shaded area represents frontier and developing. Asia's 90th and 10th percentiles.

\section{B. Banking efficiency}

5. Net interest margins (Median, percent, 2009)

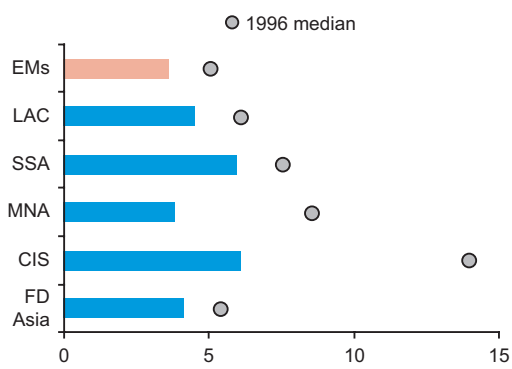

Sources: Demirgüç-Kunt and others (2010) data set; and author's calculations.
2. Domestic bank deposits (Percent of GDP)

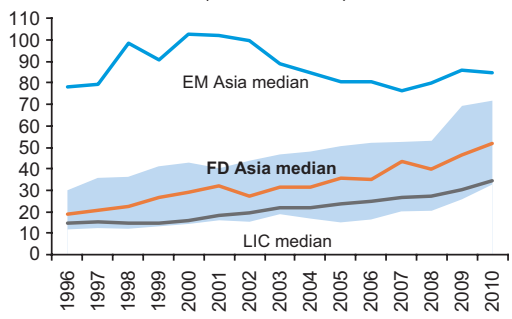

Source: Authors' estimations based on FinStat database and Demirgüç-Kunt and othersss (2010) data set.

Note: Shaded area represents frontier and developing Asia's 90th and 10th percentiles.

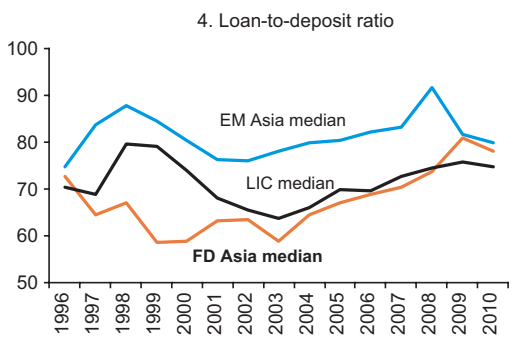

Source: Authors' estimations based on FinStat database and Demirgüç-Kunt and others (2010) data set.

\section{Figure 6.6 Banking Size and Efficiency in Frontier and Developing Asia}

Note: $\mathrm{CIS}=$ Commonwealth of Independent States; $\mathrm{EM}=$ emerging market; FD = frontier and developing; $\mathrm{LAC}=$ Latin America and Caribbean; MNA = Middle East and North Africa; SSA = sub-Saharan Africa.

\section{(C) International Monetary Fund. Not for Redistribution}




\section{Banking Systems}

Several indicators of size and efficiency show that frontier and developing Asia's banking systems have deepened since 1990, but the nature of banking remains mostly short term, as evidenced by the maturity structure on the asset and liability sides of bank balance sheets.

- Depth: Indicators of depth, measured by private credit and total bank deposits as percentages of GDP, display a clear upward trend in frontier and developing Asian economies, particularly since 2000. For instance, private credit in Lao P.D.R., Mongolia, and Vietnam has almost tripled since 2002 and has quadrupled in Bhutan and Cambodia, albeit from a low base. As can be seen in Figure 6.6A, panels 2 and 3, banking system depth in the median frontier and developing Asian economy is rapidly converging to levels observed in the median emerging market Asian economy. However, considerable heterogeneity can be observed in patterns of banking sector deepening. For instance, in 2010, the ratio of private credit to GDP in the median frontier and developing Asian economy was more than three times that of a country in the bottom 10th percentile.

- Efficiency: In line with the rapid growth in credit to the private sector, intermediation efficiency, as proxied by the loan-to-deposit ratio, has increased in recent years (Figure 6.6A, panel 4). Furthermore, interest margins in frontier and developing Asia (Figure 6.6B, panel 5) have declined since the mid-1990s and are similar to those in emerging markets. Bank concentration in frontier and developing Asia (Figure 6.6B, panel 6) is also significantly lower than that in other regions, such as subSaharan Africa, Latin America and the Caribbean, and the Middle East and North Africa. Taken together, these developments suggest that reforms during the past few decades have served to increase efficiency.

- The role of state-owned banks: One notable feature of banking systems in frontier and developing Asian economies is the large share of stateowned banks (Figure 6.7-see also Chapter 7 on Financial Sector Vulnerabilities). State-owned banks span a diverse range: (1) state-owned commercial banks (in Bangladesh, Bhutan, Lao P.D.R., Mongolia, Nepal, and Vietnam); (2) state-owned development banks (Bhutan Development Bank, Development Bank of Mongolia, Vietnam Development Bank); and (3) specialized state-owned banks (Rural Development Bank of Cambodia, Vietnam Bank for Social Policy). The prevalence of stateowned banks reflects both policy choices and a historical legacy of supporting the development of homegrown banks at their early stages (such as in Bhutan) to align growth with national objectives (in Bangladesh and Vietnam) and implement financial crisis management (the state bank in Mongolia). Several countries' banking systems initially started as monobanks (such as in Vietnam) or a nationalized system (Bangladesh—Ahmed and Al-Hassan 2011). 


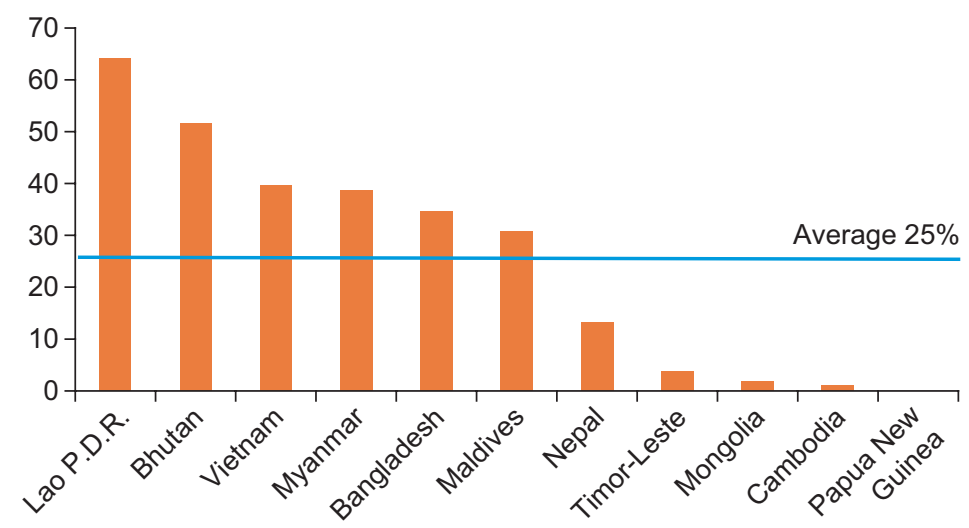

Figure 6.7 State-Owned Banks in Frontier and Developing Asia (Percent, share of total assets)

Source: Authors' estimates.

Note: Based on 2011 data except for Cambodia (2009), Bangladesh, Timor-Leste, and Papua New Guinea (all for 2010).

State-owned banks can be effective in coping with market failures by overcoming good borrowers' collateral problems and lack of credit histories, for example, and by providing public goods for productive investment (Levine 2011). However, they are often susceptible to government failure. For example, La Porta, Lopez-de-Silanes, and Shleifer (2002) find that higher government ownership of banks in 1970 was associated with slower subsequent financial development and lower growth of per capita income and productivity. In frontier and developing Asia, many state-owned banks suffer from undercapitalization and higher levels of nonperforming loans than other banks.

\section{Financial Markets}

Liquid and deep domestic debt markets can be useful vehicles for diversifying the funding of governments, households, and corporations; attracting the financing required for huge infrastructure needs; broadening the range of assets available for local institutional and retail investors; and providing an additional channel for financial intermediation. Evidence, however, points to a natural sequencing with which various segments of the financial system develop, with capital markets typically following banking. ${ }^{12}$ Consistent with these observations, financial markets and other players in frontier and developing Asia, although growing, remain smaller, less numerous, and less liquid and provide a narrower range of services than those in emerging markets.

\footnotetext{
${ }^{12}$ de la Torre, Feyen, and Alain (2011) find that financial activities that are the least prone to market friction emerge and develop first (such as deposit collection in banking). Activities that are subject to strong friction require more time. Debt and equity securities markets are strongly boosted by scale and network effects and typically take longer to develop. See also Demirgüç-Kunt, Feyen, and Levine (2012).
} 
- Equity markets: Stock market capitalization has grown in frontier and developing Asia, especially in the past few years, but remains significantly lower than in emerging market Asia (Figure 6.8, panel a). The number of listed companies is also small in many frontier and developing Asian economies (20 in Bhutan, 1 in Cambodia, 2 in Lao P.D.R., 6 in Maldives). In general, liquidity remains low and access to equity markets concentrated in a limited number of enterprises, with banks and nonbank financial institutions constituting a large share of listings. Available data about stock market turnover ratios (annual trading volume relative to the size of the market) show substantial variability among frontier and developing Asian economies. At about 140 percent of GDP, the ratio is very high in Vietnam, while it is only about 2 percent in Nepal. The shallowness of equity markets renders them susceptible to sudden price movements and greater disruptions, which can undermine confidence in their integrity (IMF 2012).

- Bond markets: The small size and liquidity of equity markets is mirrored in the bond side of capital markets. Domestic government bond markets are mostly centered on primary markets (Figure 6.8, panel b), with secondary markets largely undeveloped. Some frontier and developing Asian economies have started to issue treasury bills (T-bills) through securitization of overdrafts from the central bank (Maldives, Nepal); other countries are in the process of developing T-bill auction systems (for example, Mongolia). Several countries have successfully issued longer-term domestic government bonds (Bangladesh, Vietnam) aimed at boosting infrastructure development. At the same time, the authorities need to remain vigilant about issues of fiscal dominance. For instance, excess supply of government securities in conjunction with large fiscal deficits can hinder healthy bond market development. International sovereign bond issuance has also increased during the past decade, but is limited to a few countries (for example, Mongolia and Vietnam).

- Other markets: Available evidence suggests that money markets (interbank markets) in frontier and developing Asia are still shallow as measured by the scale of their operations and the number of participants. Official foreign exchange market turnover data are not available for most countries in frontier and developing Asia, but evidence suggests that most have already established interbank foreign exchange markets. But these markets are still at an early stage of development and comprise over-the-counter transactions among authorized dealers (Figure 6.8, panel d). Some exceptions are Papua New Guinea, which has a brokerage system, and Vietnam, which has market-making arrangements. Forward exchange rate markets are still nascent, as indicated by the IMF's Annual Report on Exchange Rate Arrangement and Exchange Rate Restrictions database, which shows the presence of foreign exchange forward markets in only five frontier and developing Asian economies (Bangladesh, Mongolia, Nepal, Papua New Guinea, Vietnam).

\section{(C) International Monetary Fund. Not for Redistribution}


a. Stock market capitalization

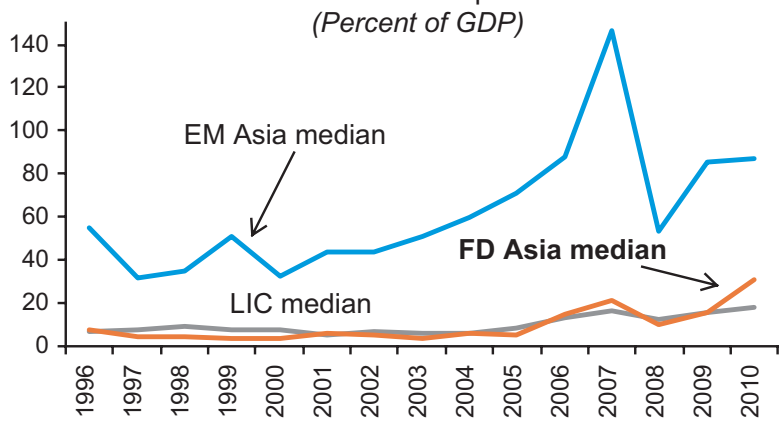

Sources: Demirgüç-Kunt and others (2010) data set, and authors' calculations.

b. Stock market capitalization

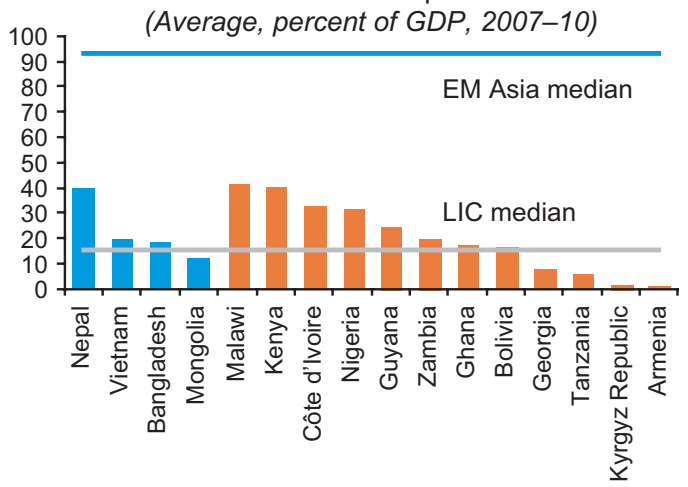

Sources: Demirgüç-Kunt and others (2010) data set; and authors' calculations.

c. Domestic securitized government bond stock

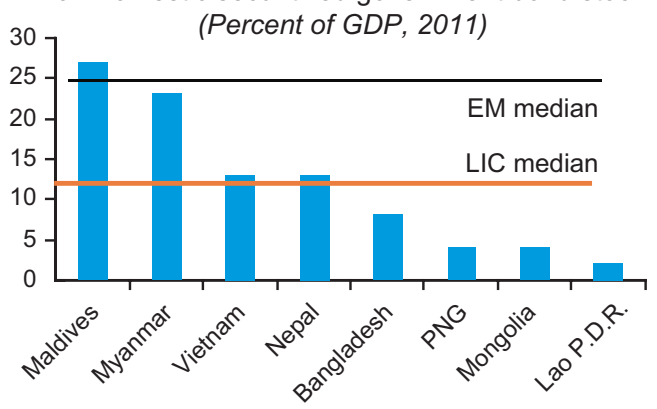

Source: Authors' estimates.

Figure 6.8 Financial Markets in Frontier and Developing Asia

Note: $\mathrm{EM}=$ emerging market, FD = frontier and developing, $\mathrm{LIC}=$ lower-income country, PNG = Papua New Guinea. 
d. Foreign Exchange Market in 2011

\begin{tabular}{|c|c|c|c|c|}
\hline & Spot & & Interbank & Forward \\
\hline Bangladesh & • & • & Over-the-counter (OTC) & • \\
\hline Bhutan & • & & & \\
\hline Cambodia & • & • & OTC & \\
\hline Lao P.D.R. & • & • & OTC & \\
\hline Maldives & • & & & \\
\hline Mongolia & • & • & OTC & - \\
\hline Myanmar & • & • & OTC & \\
\hline Nepal & • & • & OTC & • \\
\hline Papua New Guinea & - & • & OTC, Brokerage, Market-making & • \\
\hline Timor-Leste & & & & \\
\hline Vietnam & - & • & Market-making & • \\
\hline
\end{tabular}

Source: IMF, Annual Report on Exchange Rate Arrangement and Exchange Rate Restrictions (AREAER) database.

e. Pension fund assets,

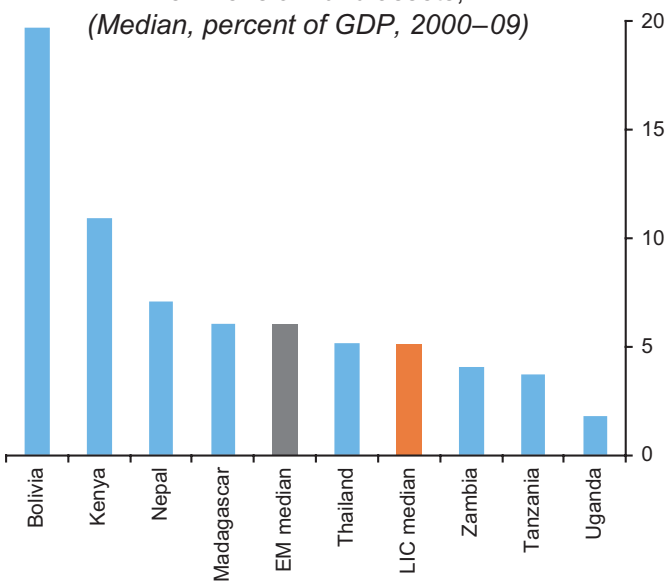

Sources: Demirgüç-Kunt and others (2010) data set; and World Bank.

f. Insurance company assets,

(Median, percent of GDP, 2007-09)

10

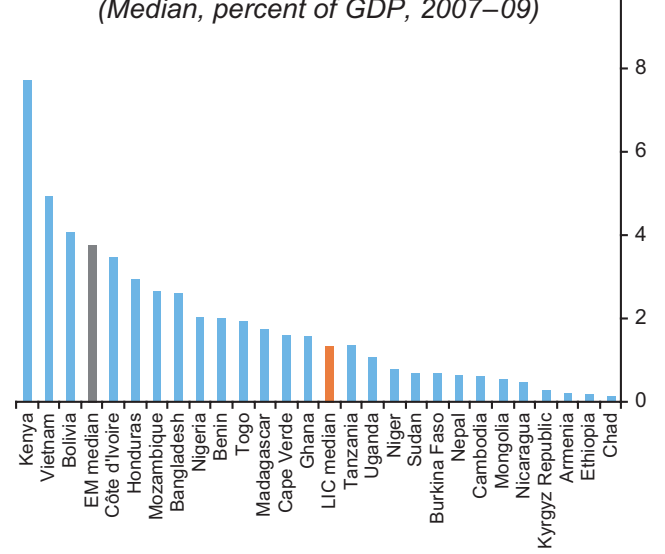

Sources: Demirgüç-Kunt and others (2010) data set; and World Bank.

Figure 6.8 (Continued)

\section{(C) International Monetary Fund. Not for Redistribution}


- Institutional investors (insurance, pension): As providers of financial services for long-term saving and risk sharing (such as health, life, property, and employment shocks), insurance markets and pension funds can facilitate the growth of capital markets (IMF 2012). Contractual saving institutions are, however, in their infancy in most frontier and developing Asian countries. Available data suggest that the insurance-assets-to-GDP ratio is less than 2 percent in most low-income countries, whereas some countries, including Vietnam, exceed the median value for emerging markets (Figure 6.8, panel f). However, insurance companies in frontier and developing Asia typically focused on the non-life segments of business, and the life segment typically constitutes a small share of their business. Similarly, pension fund assets remain small in most countries (Nepal is a notable exception; Figure 6.8, panel e), with pension funds typically not matching their long-term liabilities with their investment strategies.

\section{Financial Inclusion}

Access to and use of financial services by a large share of households and enterprises is an important dimension of financial development. In tandem with the recent growth in private sector credit, financial inclusion in frontier and developing Asia has broadened, but continues to lag emerging market Asian economies significantly and remains limited, particularly for small and medium enterprises, suggesting considerable scope for making finance more inclusive.

- Household access to financial services: Use of banking services in frontier and developing Asian economies is relatively better. Account penetration rates, measured by the presence of an account at a formal financial institution, are higher than in the median low-income country, but lag emerging market Asia and other middle-income countries (Figure 6.9, panel a). The use of savings and health insurance products also continues to lag emerging market Asian countries (Figure 6.9, panels d and f). One area in which frontier and developing Asian economies appear to be trailing other lowincome countries is in the use of mobile phones to make payments (Figure 6.9, panel b). In other parts of the world, use of this technology has proved an effective way for poor households to reduce transaction costs, facilitate payments, and increase the use of formal financial intermediaries (IMF 2012).

- Firms' access to financial services: Evidence from the World Bank's Enterprise Surveys suggests that access to finance is more limited in frontier and developing Asia than in emerging market Asia (Figure 6.10). In particular, relative to countries in frontier and developing Asia, surveyed firms in emerging markets are about one-third as likely to report being credit constrained, and twice as many report having either a bank loan or a line of credit. Moreover, a higher share of small and medium enterprises than 

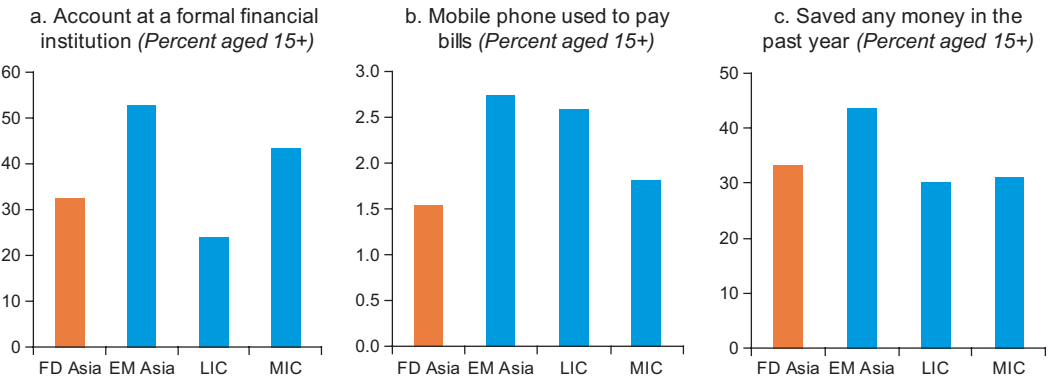

d. Saved at a financial institutions in the past year (Percent aged 15+)

e. Credit card (Percent aged 15+) Personally paid for health
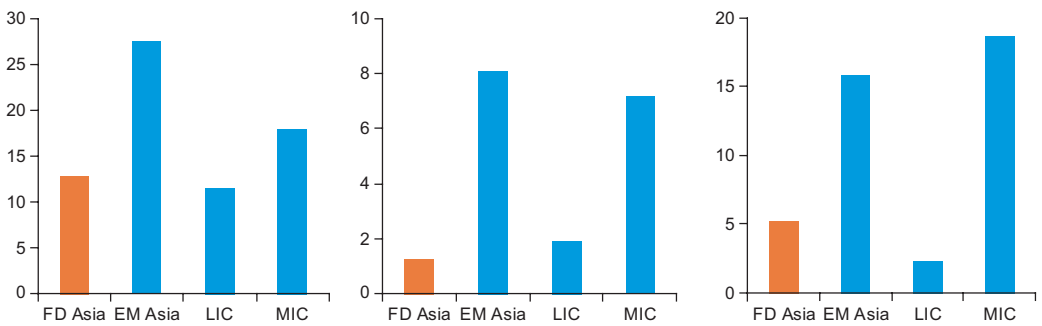

Figure 6.9 Financial Inclusion in Frontier and Developing Asia: Household (2011)

Source: Demirgüç-Kunt and Klapper (2012).

Note: The income group classifications are those used by the World Bank. FD Asia data are available from Bangladesh, Cambodia, Lao P.D.R., Mongolia, Nepal, and Vietnam. EM Asia data comprise China, India, Indonesia, Korea, Malaysia, Philippines, Singapore, Sri Lanka, and Thailand. FD = frontier and developing, EM = emerging market, LIC $=$ lowerincome country, MIC = middle-income country.

larger firms in frontier and developing Asian economies report credit constraints as a major obstacle to their growth and operations than in emerging markets.

\section{BENCHMARKING FINANCIAL SYSTEMS}

The previous section described stylized facts about financial deepening in frontier and developing Asia, showing that although countries have made considerable progress, more remains to be done. The question then arises of how much, if at all, frontier and developing Asian economies should facilitate financial deepening. How realistic is it to expect frontier and developing Asian economies to deepen and diversify financial systems to the levels observed in emerging market economies in Asia?

To address these questions, financial deepening in frontier and developing Asia is systematically benchmarked after controlling for a number of possible economic and structural determinants (such as income per capita, size, demographic variables). In particular, the behavior of selected financial indicators is tracked in relation to a "structural benchmark" level, based on a statistical methodology 


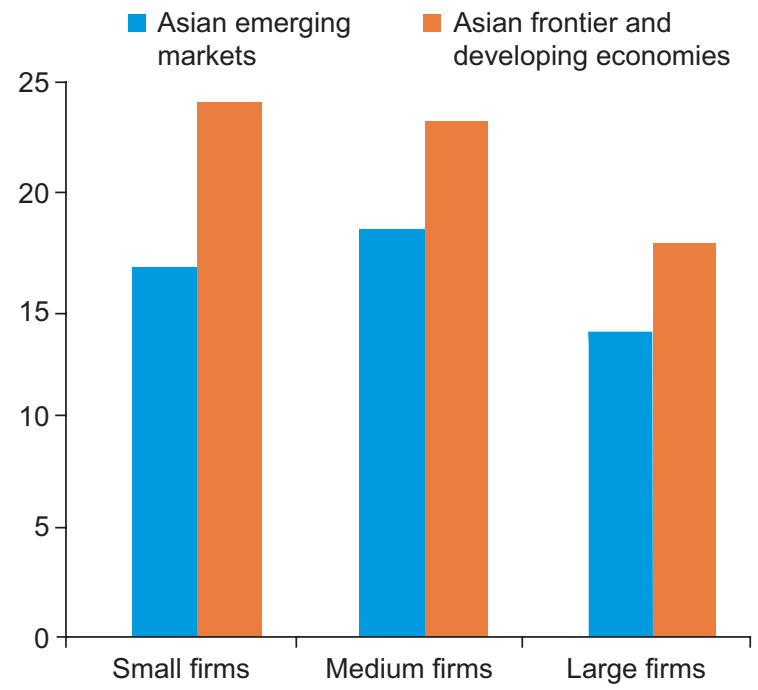

Figure 6.10 Share of Firms that Report Access to Credit as Constraint (By firm size, average 2002-10)

Source: World Bank enterprise surveys.

developed by the World Bank (Feyen and others, 2011) ${ }^{13}$ A "gap" is defined for each financial indicator in country $i$ and year $t$ as the difference between the benchmark and the actual level. A positive (negative) gap value thus indicates under- (over-) performance.

The analysis reveals the interesting result that many countries in frontier and developing Asia have deepened by more than would have been expected from their structural characteristics alone. The median gap in the ratio of private credit to GDP for the median frontier and developing Asian economy was very small in 2001. During the subsequent decade, this gap became significantly negative (Figure 6.11, panel a). This overperformance is particularly striking in comparison with the median emerging market Asian economy, for which gaps in private credit increased during the decade following the Asian crisis of the late 1990s, suggesting that the median emerging market Asian economy is underperforming relative to levels predicted by its structural characteristics (Figure 6.11, panel b).

\footnotetext{
${ }^{13}$ The benchmarks are derived as the predicted values from quantile (median) regression analysis that accounts for a country's structural variables: income, country size, population density, age-dependency ratio, and other structural characteristics that affect financial development (such as dummies to capture whether a country is an offshore center, oil exporter, or country in transition). Note that the regression model does not account for factors that directly capture financial policy. Instead, the objective is to account for factors that lie outside the policy purview (at least in the short term). Deviations of the actual from the expected level of financial development can then be explained by the impact of policies and institutional quality in a country.
} 
a. Private credit in frontier and developing Asia (Percent of GDP, 2001-10)

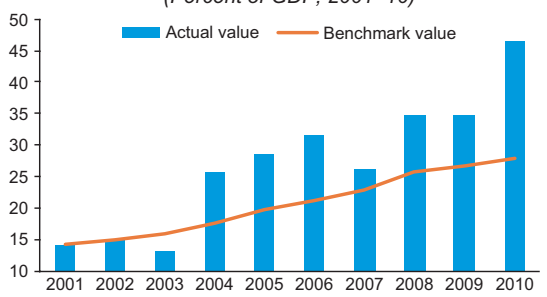

c. Private credit

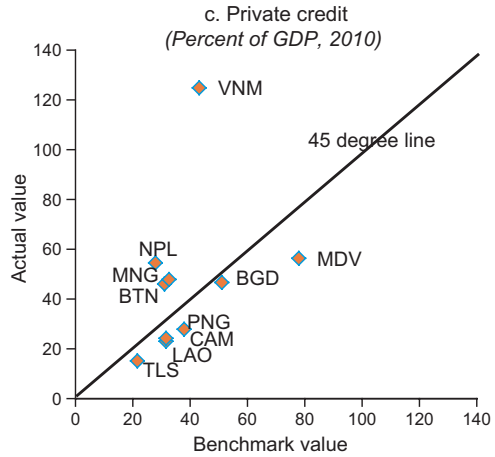

b. Private credit in emerging Asia (Percent of GDP, 2001-10)

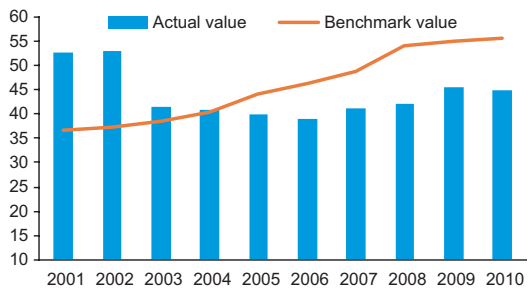

d. Stock market capitalization (Percent of GDP, 2010)

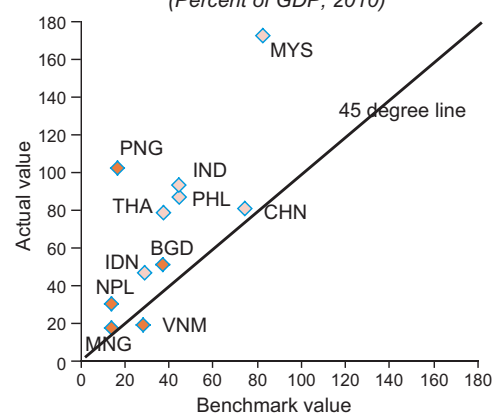

Figure 6.11 Benchmarking-Financial Depth

Sources: Authors' estimation based on World Bank Fin Stats (2012) data set.

Notes: Benchmark values are obtained from a regression that controls for structural factors (economic development, demographics, population density, and other fundamentals). BGD = Bangladesh, BTN = Bhutan; CAM = Cambodia; CHN = China; IDN = Indonesia; IND = India; LAO = Lao P.D.R.; MDV = Maldives; MNG = Mongolia; MYS = Malaysia; $\mathrm{NPL}=$ Nepal; PNG = Papua New Guinea; PHL = Philippines; THA = Thailand; TLS = Timor-Leste; VNM = Vietnam.

A closer inspection of these results indicates that the overperformance of private credit relative to the benchmark in the median emerging market Asian economy is driven largely by the behavior of a few countries. Figure 6.11, panel c illustrates that Bhutan, Mongolia, Nepal, and Vietnam have financial systems that are considerably larger than predicted by their structural characteristics. Moreover, observed levels of stock market capitalization in Bangladesh, Nepal, and Papua New Guinea in 2010 are much higher than predicted by their structural fundamentals (Figure 11, panel d). Overperformance relative to the benchmark can be an indication of sound macroeconomic and financial sector policies, but many of these countries have also witnessed a rapid increase in deepening, which can pose risks to stability (see also Chapter 7 on Addressing Financial Sector Vulnerabilities).

As evidenced from the experience of emerging markets during the Asian crisis and the experience of advanced economies during the global financial crisis, rapid deepening can fuel credit and asset price booms and can have destabilizing macroeconomic effects, particularly in the absence of appropriate financial oversight and policies. Indeed, research suggests that a private-credit-to-GDP 
a. Commercial banks' accounts per 1,000 adults, 2010

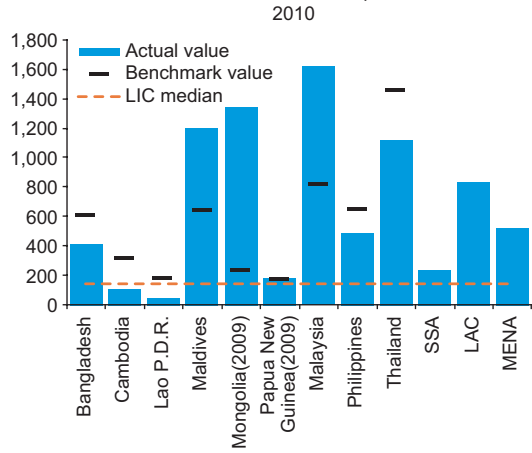

c. Firms with line of credit, all firms, 2010

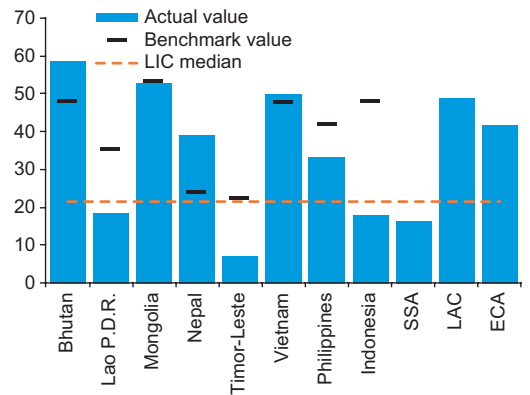

b. Number of branches per 100,000 adults commercial banks, 2010

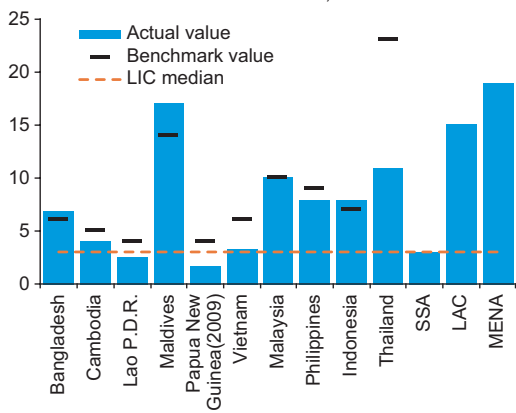

d. Firms with line of credit, small firms, 2010

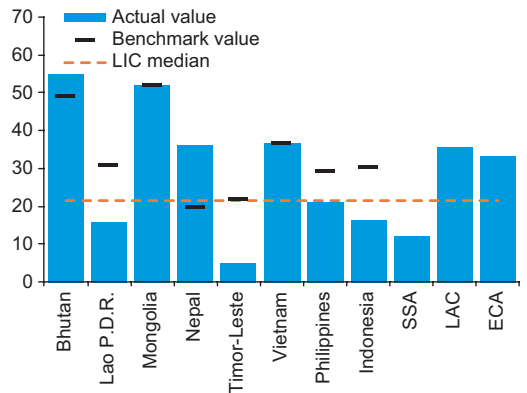

Figure 6.12 Benchmarking-Financial Inclusion

Sources: Authors' estimation based on World Bank Fin Stats (2012) dataset.

Notes: $\mathrm{ECA}=$ Europe and Central Asia; LAC = Latin America and the Caribbean; LIC = low-income country; MENA = Middle East and North Africa; SSA = sub-Saharan Africa.

ratio 90-100 percent above the structural benchmark is 50 percent more likely to be associated with a credit boom (Barajas and others 2013). In addition, this type of boom is almost always a "bad" or subpar boom-that is, one that ends in lowgrowth episodes or even banking crises. Particular attention should thus be paid to strengthening prudential and supervisory oversight and macroeconomic management in these frontier and developing Asian economies.

Benchmarking indicators of financial inclusion also points to the considerable cross-country heterogeneity within frontier and developing Asia, although most countries have more inclusive financial systems than the median low-income countries. With respect to account penetration, as proxied by commercial bank accounts per thousand adults and the number of branches, many countries are lagging the benchmark levels expected to find in countries with similar structural characteristics (for example, Cambodia, Lao P.D.R., Papua New Guinea), while others (for example, Maldives, Mongolia) are overperforming (Figure 6.12, panels $\mathrm{a}$ and $\mathrm{b}$ ). The evidence on firms' access to funding from official sources is also mixed (Figure 6.12, panels c and d). Several countries struggle to provide credit to small firms (for example, Lao P.D.R., Timor-Leste), suggesting considerable 
scope for greater financial access to ensure that entrepreneurship can thrive and create jobs. ${ }^{14}$

\section{HOW TO PROMOTE FINANCIAL DEEPENING}

The discussion in the previous sections points to sizable cross-country heterogeneity within frontier and developing Asia, suggesting differing areas and approaches for deepening. In frontier markets, where financial intermediation has grown rapidly, the main challenge is to deepen capital markets sustainably and encourage long-term investing while strengthening financial oversight. In most countries in the group, broadening financial inclusion to allow for greater risk sharing and intertemporal consumption smoothing (as provided by saving and credit services) — and even simple payment services_ _ and financing for small and medium enterprises remain critical policy challenges.

Many of the impediments to financial deepening in frontier and developing Asia today prevailed, or continue to be present, in emerging market Asia to varying degrees. Broadly speaking, efforts and actions to deepen and broaden the financial system and increase access to financial services can be organized around three interrelated elements: (1) policies to ensure stable macroeconomic environments, (2) institutional and infrastructure reforms to create enabling frameworks for markets and private initiatives, and (3) regulatory and oversight policies to address inefficiencies and risks generated by markets and market players. ${ }^{15}$

- Sustaining macro-stability: Consolidation of fiscal positions through reforms (reducing fiscal dominance) and greater central bank autonomy, and the resulting enhanced policy credibility and reduced uncertainty over investment returns, can play a critical role in increasing both the demand for and supply of financial services. The absence of these factors, for instance, typically increases the risks of holding bonds, stymieing local bond market development. Financial repression, through artificially suppressed interest rates, further reduces their attractiveness. Similarly, fiscal dominance can lead to an issuance volume exceeding the absorption capacity of the existing investor base (banks, insurance companies, pension funds). This not only stunts bond market development, but also raises financial stability concerns as the sovereign and bank balance sheets become intertwined.

- Public policy for institutional reform and infrastructure: Interventions that support technological innovation, encourage competition, and create infrastructures to promote participation (such as the Asian Bond Market Initiative) can help achieve economies of scale and reduce costs in financial

\footnotetext{
${ }^{14}$ Lack of access to finance is a key constraint to job creation, particularly for small and medium enterprises, which tend to be more labor intensive than large firms. Studies have shown that access to finance has the largest employment effects for small and medium enterprises, which are also the most credit constrained (IFC 2013).

${ }^{15}$ This section draws on the analysis in IMF (2012) to document the role of public policy in facilitating deepening.
} 
services provision. At the same time, removal of inefficient regulations and compulsory lending policies, and market-supporting reforms to build up missing market segments, can have a positive impact on financial system development.

- Undertaking operational reforms: Reforms to remedy deficiencies in the market micro-structure can facilitate price discovery and market development. In many frontier and developing Asian economies, the absence of well-functioning interbank money markets, primary market structures (such as nontransparent and noncompetitive participation), and a longerterm investor base (insurance, pension, and mutual funds) places a drag on bond market development. ${ }^{16}$ Experiences from emerging market economies suggest that market-friendly intervention instruments and a sound repurchase agreement framework can help develop money and interbank markets, which, alongside improvements in the underlying market infrastructure (such as trading platforms, custody, and clearing and settlement systems), aids in the development of debt and equity markets.

- Rationalizing state-owned banks: Managing and gradually reducing the dominance of state-owned banks through prudential regulation, strong supervision, and well-timed privatization (ideally accompanied by improved governance and management) can contribute to the efficiency of banking systems. State-owned banks should have a clear mandate to cope with market failures on a noncommercial bank basis. They should not be a source of cheap credit, but should instead serve as funding vehicles for productive investments. ${ }^{17}$

- Addressing information gaps: An area in which countries in frontier and developing Asia are clearly lagging emerging market Asia is in the strength of their informational and contractual institutions (Figure 6.13). Country experiences suggest that policy interventions to strengthen informational and contractual frameworks, such as building or upgrading credit registries and strengthening collateral and risk insurance, can play an instrumental role in fostering financial deepening and increasing access to financial services by small and medium enterprises.

- Promoting inclusion by overcoming scale barriers: Frontier and developing Asia is also lagging other low-income countries and emerging markets in

\footnotetext{
${ }^{16}$ Furthermore, experience from emerging market economies suggests that equity markets often mature once the relevant supportive financial markets develop, because the infrastructure, liquidity, and institutions that arise from foreign exchange, money, and government securities markets also facilitate the development of stock exchanges. Similarly, corporate bonds, in addition to the effects noted above, are also affected by the level of development in the government bond market, given its role as an asset-pricing reference.

${ }^{17}$ It should be noted that the provision of low-cost loans to state-owned enterprises by state-owned banks in many frontier and developing Asian economies can also slow the development of corporate bond markets.
} 
a. Legal rights and credit information (2012)

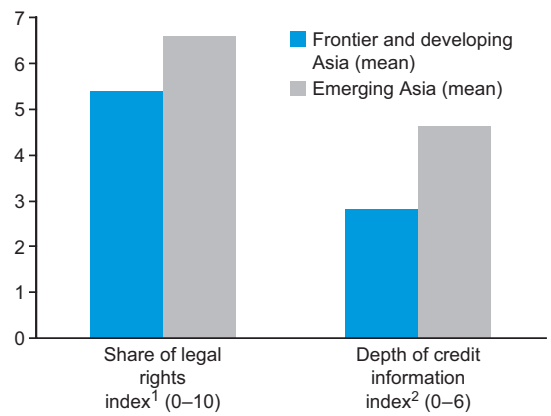

${ }^{1}$ This index measures the degree to which collateral and bankruptcy laws protect the rights of borrowers and lenders and thus facilitate lending.

${ }^{2}$ This index measures rules and practices affecting the coverage, scope and accessibility of credit information available through either a public credit registry or a private credit bureau. b. Public credit registry and private credit bureau (2012)

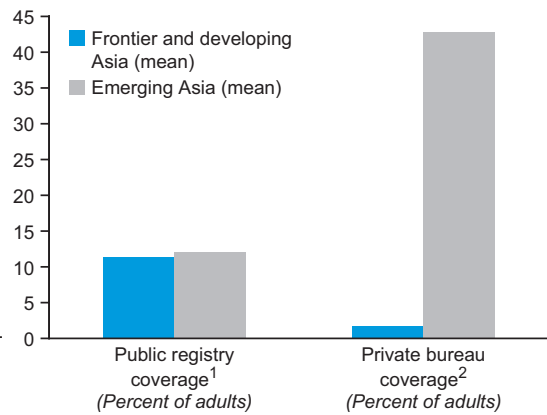

${ }^{1}$ The number of individuals and firms listed in a public credit registry with information on their borrowing history from the past 5 years.

${ }^{2}$ The number of individuals and firms listed by a private credit bureau with information on their borrowing history from the past 5 years.

Figure 6.13 Credit Information Gap

Source: World Bank, Doing Business database (2013).

Note: Data for emerging Asia includes China.

the use of mobile technology for payments and financial services. The successes of M-Pesa in Kenya and Smart Money in the Philippines suggest that the use of mobile technology, supported by flexible regulation, can help lower costs and promote broader access to payments services for underserved segments of the population (in rural areas, for example).

- Public policy for risk oversight and management. Proactive policies to oversee market activity, support continuous risk monitoring, and mitigate systemic risks are essential for the benefits of financial deepening to materialize, particularly in light of the rapid growth of credit in many frontier and developing Asian countries.

- Given the dominance of banks in financial systems in frontier and developing Asia, and their linkages to capital (stock and bond) markets, ensuring the good performance of banks and managing the risks to and from the banking system through prudent regulation and strong supervision are critical. A sound banking system can also provide a solid platform for capital market development, while minimizing associated risks.

- The experience from the Asian crisis of the late 1990s suggests that the pace of financial liberalization and associated deepening needs to be carefully calibrated to the prudential oversight capacity. With greater foreign bank penetration, promoting cross-border supervisory cooperation and information sharing will become increasingly important for managing risks.

- Policies to broaden financial access require a concomitant widening of the regulatory and supervisory perimeter to minimize regulatory arbitrage and financial system risks. Moreover, as seen in India, policies that seek to 
broaden financial access too aggressively can have ramifications for consumer indebtedness, requiring a commensurate strengthening of consumer protection.

\section{CONCLUSION}

Financial deepening is an imperative for frontier and developing Asia for several reasons. First, financial development can drive economic growth in these economies. Second, better financial services will allow firms and households to reduce transaction costs and provide opportunities for smoothing income, thus reducing poverty and income inequality. Third, financial deepening can help strengthen these economies' resilience and capacity to cope with shocks and mitigate macroeconomic volatility.

Financial systems in frontier and developing Asia remain at a nascent stage of development. They are largely bank based, and although banking systems have deepened and efficiency has increased, the share of state-owned banks remains large. Financial markets in frontier and developing Asia, although growing, remain smaller, less numerous, and less liquid. In particular, stock markets have grown, especially over the past decade, but remain significantly smaller and less liquid than in emerging market Asia. Available data suggest that bond markets and money markets and insurance and pension institutions remain immature, suggesting further scope for developing capital markets. Financial inclusion in frontier and developing Asia has also broadened, but continues to lag emerging market Asia.

Some countries in frontier and developing Asia, however, have deepened by more than would have been expected from their structural characteristics alone, implying risks to stability. Rapid deepening can fuel credit and asset price booms and destabilize an economy, particularly absent appropriate financial oversight and policies. To maximize the benefits, country efforts and actions to deepen and broaden the financial system and increase access to financial services should be centered around three interrelated pillars: (1) policies to ensure stable macroeconomic environments, (2) institutional and infrastructure reforms to create enabling frameworks for markets and private initiatives, and (3) regulatory and oversight policies to address inefficiencies and risks generated by markets and market players.

\section{REFERENCES}

Ahmed, F., and A. Al-Hassan. 2011. "Policy Challenges Facing the LIC Financial Sector." Unpublished. International Monetary Fund, Washington.

Beck, T., A. Demirgüç-Kunt, and R. Levine. 2007. "Finance, Inequality, and the Poor." Journal of Economic Growth 12 (1): 27-49.

Barajas, A., T. Beck, E. Dabla-Norris, and S. Yousefi. 2013. "Too Hot, Too Cold, or Just Right? Assessing Financial Sector Development across the Globe.” IMF Working Paper 13/81, International Monetary Fund, Washington. 
Dabla-Norris, E., and S. Narapong. 2013. "Revisiting the Link between Finance and Macroeconomic Volatility.” IMF Working Paper 13/29, International Monetary Fund, Washington.

de la Torre, A., E. Feyen, and I. Alain. 2011. "Financial Development: Structure and Dynamics." World Bank Policy Research Working Paper 5854, World Bank, Washington.

Demirgüç-Kunt, A., M. Čihák, E. Feyen, T. Beck, and R. Levine. 2010. "Financial Development and Structure Dataset." Based on T. Beck, A. Demirgüç-Kunt, and R. Levine. 2000, "A New Database on the Structure and Development of the Financial Sector." World Bank Economic Review 14 (3): 597-605.

Demirgüç-Kunt, A., E. Feyen, and R. Levine. 2012. "The Evolving Importance of Banks and Securities Markets." NBER Working Paper 18004, National Bureau of Economic Research, Cambridge, Massachusetts.

Demirgüç-Kunt, A., and L. Klapper. 2012. "Measuring Financial Inclusion: The Global Findex Database." World Bank Policy Research Working Paper 6025, World Bank, Washington.

Feyen, E., E. Al Hussainy, A. Coppola, A. Ize, K. Kibbuka, and H. Ren. 2011. "FinStats 2011: A Ready-to-Use Tool to Benchmark Financial Sectors Across Countries and over Time." World Bank, Washington.

Financial Stability Board (FSB), International Monetary Fund (IMF), and World Bank. 2011. "Financial Stability Issues in Emerging Market and Developing Economies." Report to the G20 Finance Ministers and Central Bank Governors.

Honohan, P. 2004. "Financial Development, Growth and Poverty: How Close Are the Links." in Financial Development and Economic Growth: Explaining the Links, edited by C. Goodhart. London: Palgrave.

International Finance Corporation (IFC). 2013. "Assessing Private Sector Contributions to Job Creation and Poverty Reduction: An IFC Open Source Study." Washington.

International Monetary Fund (IMF). 2012 (April). "Enhancing Financial Sector Surveillance in LICs: Financial Deepening and Macro-Stability." IMF Policy Paper, Washington.

La Porta, R., F. Lopez-de-Silanes, and A. Shleifer. 2002. "Government Ownership of Banks." Journal of Finance 57 (1): 265-301.

Lane, P. R., and G. M. Milesi-Ferretti. 2010. "Updated and Extended External Wealth of Nations Dataset." Based on P. R. Lane and G. M. Milesi-Ferretti. 2007. "The External Wealth of Nations Mark II: Revised and Extended Estimates of Foreign Assets and Liabilities, 1970-2004." Journal of International Economics 73 (2): 223-50.

Levine, R. 2005. "Finance and Growth: Theory and Evidence." In Handbook of Economic Growth, Vol. 1. Edited by P. Aghion and S. Durlauf. Amsterdam: North Holland.

- 2011. "Financial Development, Economic Growth, and Income Distribution." Presentation at International Monetary Fund seminar, April 28.

Levine, R., N. Loayza, and T. Beck. 2000. "Financial Intermediation and Growth: Causality and Causes." Journal of Monetary Economics 46 (1): 31-77.

Lin, S., and H. Ye. 2011. "The Role of Financial Development in Exchange Regime Choices." Journal of International Money and Finance 30 (4): 641-59.

Obstfeld, M., and A. M. Taylor. 2004. Global Capital Markets: Integration, Crisis, and Growth. Cambridge, Massachusetts: Cambridge University Press.

Rajan, R., and L. Zingales. 2001. "Financial System, Industrial Structure, and Growth." Oxford Review of Economic Policy 17 (4): 467-82. 


\title{
Addressing Financial Sector Vulnerabilities
}

\author{
Todd SCHneider, Faisal Ahmed, Rina BhatTACHARYA, \\ SERGEI Dodzin, SOUVIK GUPTA, JONGSOON SHIN, AND XUAN TU
}

Financial sector development and deepening are broadly seen to be essential to long-term growth because they enable saving and facilitate investment (see Chapter 6 on Financial Sector Deepening). Although the nexus and direction of causality between growth and financial deepening are subject to debate, the two are clearly linked. Few, if any, of today's dynamic emerging markets- the frontier and developing economies of the 1980s and 1990s-experienced high and sustained levels of growth without an accompanying increase in financial deepening. Virtually all of today's Asian emerging markets boast highly developed banking and financial intermediation, effective capital and foreign exchange markets, and close links to global financial systems.

With change and growth come new risks. Financial innovation and development—when poorly supervised or unregulated—can, in some cases, negatively affect macroeconomic stability. Perhaps more than any other sector, finance brings with it a potent mix of opportunity and risk. The Asian financial crisis of the late 1990s underscored the critical vulnerabilities to which rapid (and unsupervised) growth in banking and capital markets can give rise. Poor risk management, overexposure to cyclical economic activity, weak governance, and directed and connected lending are only some of the potential hazards. These problems and associated risks can also be exacerbated as cross-border linkages grow, and can ultimately prove costly to output, international reserves, and public finances in the event of a crisis (see Chapter 2 on the Recent Experience of Emerging Markets).

Some of the risks facing frontier and developing Asian economies have parallels with the Asian emerging market economies of the 1990s. ${ }^{1}$ These similarities include rapid financial sector growth in the context of low supervisory capacity; poor risk management; nonbank financial activity (shadow banking), which may or may not be appropriately licensed and supervised; and, although still at an early stage, growing links with global financial markets (Ostry 1999). Also, state banks have a significant presence in many frontier and developing Asian economies, and often have ties to state enterprises. Some economies, as part of a

\footnotetext{
${ }^{1}$ This chapter covers Bangladesh, Bhutan, Cambodia, Lao P.D.R., Maldives, Mongolia, Myanmar, Nepal, Papua New Guinea, Sri Lanka, Timor-Leste, and Vietnam. Given the limited availability of data, Myanmar is not included in some analyses.
} 
development strategy, also engage in directed credit operations, which can impose quasifiscal liabilities and impinge on the profitability of private banks.

This chapter provides a snapshot of financial sector developments and risks in frontier and developing Asian economies. It focuses primarily on banks and bankrelated activities. The next section reviews the structure of financial sectors in frontier and developing Asian economies, highlighting some common characteristics. The following sections describe the state of the financial sector and look at some of the key financial sector risks in frontier and developing Asia, including domestically generated risks, external spillovers, and governance and supervisory risks. The subsequent section reviews country authorities' progress in meeting these challenges, and policy recommendations are discussed in the final section.

\section{STRUCTURE OF FINANCIAL SECTORS IN FRONTIER AND DEVELOPING ASIA}

Financial intermediation and services have grown quickly in frontier and developing Asia since early in the 2000s. The nature of growth in assets, number of institutions, and types of financial services reflect country-specific conditions, but the common trend clearly points to significant and rapid expansion. The impetus behind financial sector growth has varied-activity has sometimes been fueled by such factors as commodity booms, remittances flows, or market liberalization. Despite significant country-by-country differences, important structural characteristics of financial sectors in frontier and developing Asia include the following:

- Bank-centric systems: Financial systems in frontier and developing Asia are predominantly bank-centric (Figure 7.1). In Mongolia and Maldives, for example, banks account for nearly 100 percent of total financial system assets. In other frontier and developing Asian economies, the ratio seldom drops below 70 percent. Commercial banks (as opposed to development banks) typically represent the largest share of financial sector assets.

- Oligopolies: In many frontier and developing Asian economies, a few large players often dominate the market. Although concentration has gradually lessened, for 8 out of 12 frontier and developing Asian economies, 50 percent or more of total banking sector assets are concentrated in five or fewer institutions (Figure 7.2).

- Concentration of lending in particular sectors (real estate, extractive industries, and others): Some 50 percent of bank assets in Bangladesh are in industry and trade. In Nepal, real estate exposure (either directly or through real estate as collateral) is high-about 70 percent of commercial bank assets in Nepal are directly or indirectly exposed to the real estate sector. In Cambodia, real estate prices can have a significant impact on bank balance sheets. In Mongolia, the banking system is particularly sensitive to shocks to real estate, construction, mining, and trade.

- Rapid institutional growth: For some frontier and developing Asian economies, financial growth has been manifested in an increase in the number of 
a. Bank assets as share of financial system assets
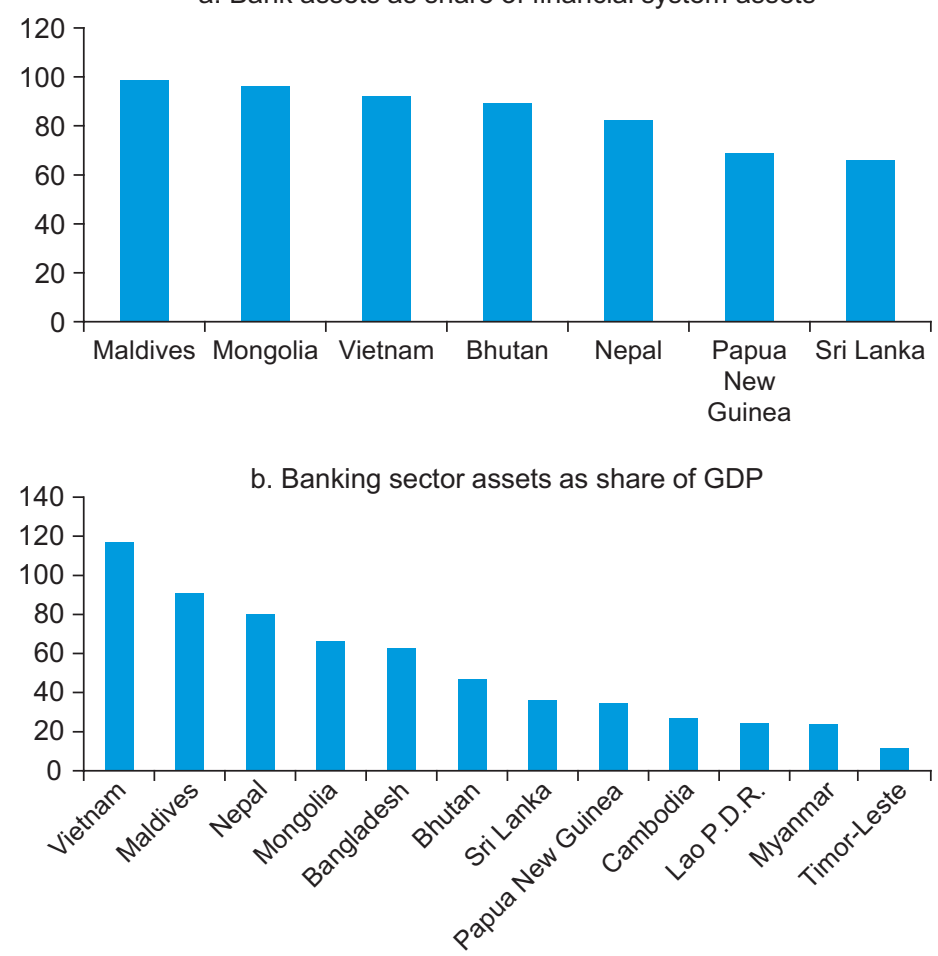

Figure 7.1 The Banking Sector in Frontier and Developing Asia Sources: National authorities; and IMF staff estimates. Note: Latest available data used.

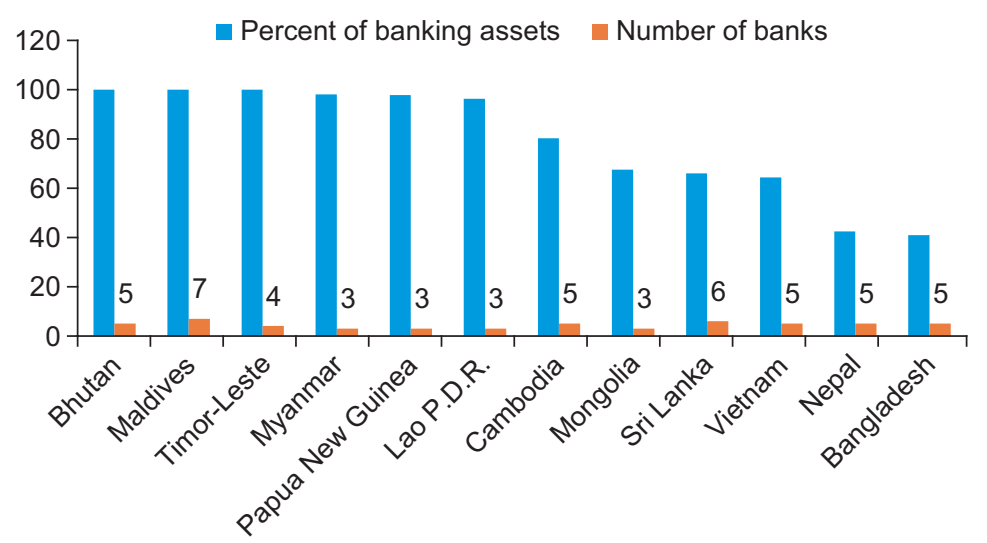

Figure 7.2 Number of Banks Holding Large Sector Share of Banking Assets Sources: Central banks; and IMF country desk data. Note: Latest available data used. 


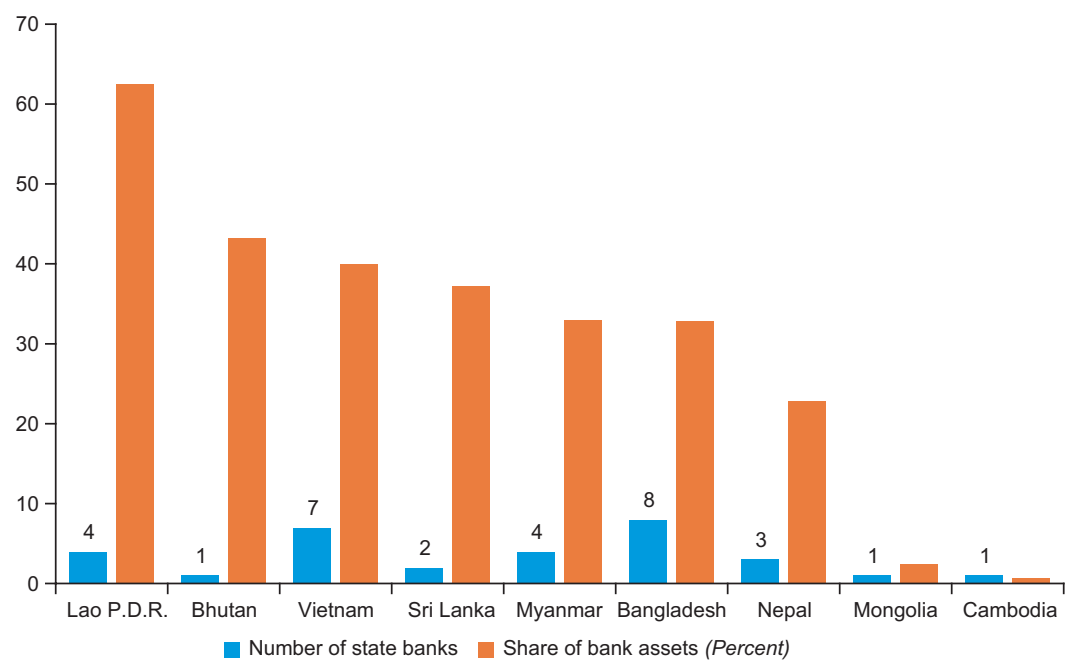

Figure 7.3 Frontier and Developing Asian State Banks' Share of Banking System Assets Sources: Central banks; and IMF, Article IV Reports, and Financial System Stability Assessment Reports.

financial institutions. In Nepal, for example, the number of financial institutions climbed from 85 to nearly 200 between 2002 and 2012-largely on the back of a steady rise in remittances inflows, a property boom, greater opportunities for financial intermediation, and a relatively lax licensing regime. In Bangladesh, the number of financial institutions has increased during the past decade as the result of a shift in government policy on licensing. However, in other countries, such as Mongolia, the number of banks has not increased substantially, although financial sector assets have grown. Papua New Guinea, Cambodia, and Lao P.D.R. have similarly seen only a moderate rise in the number of institutions compared with the increase in assets.

- State-owned banks: State-owned commercial banks are most prevalent in south Asia and the larger frontier and developing Asian economies. For instance, they constitute 30-60 percent of the banking system assets in such countries as Lao P.D.R., Maldives, Sri Lanka, and Vietnam (Figure 7.3). They frequently have the weakest balance sheets and asset quality, often encouraging regulatory forbearance (Box 7.1). In Nepal, two of the three state banks have had net negative capital for over 10 years (from the early 2000s to mid-2014); in Bangladesh and Lao P.D.R., a number of state-owned commercial banks are well below established minimum adequacy. State-owned commercial banks in frontier and developing Asia typically have weaker asset quality compared with private commercial banks (Figure 7.4)—consistent with experiences in other countries. In some cases, state-owned commercial banks with negative capitalization or high nonperforming loans (NPLs) can contribute to the weakening of confidence in the overall banking system.

- Limited foreign presence or links to international markets: Many frontier and developing Asian economies host no more than two or three foreign banks 

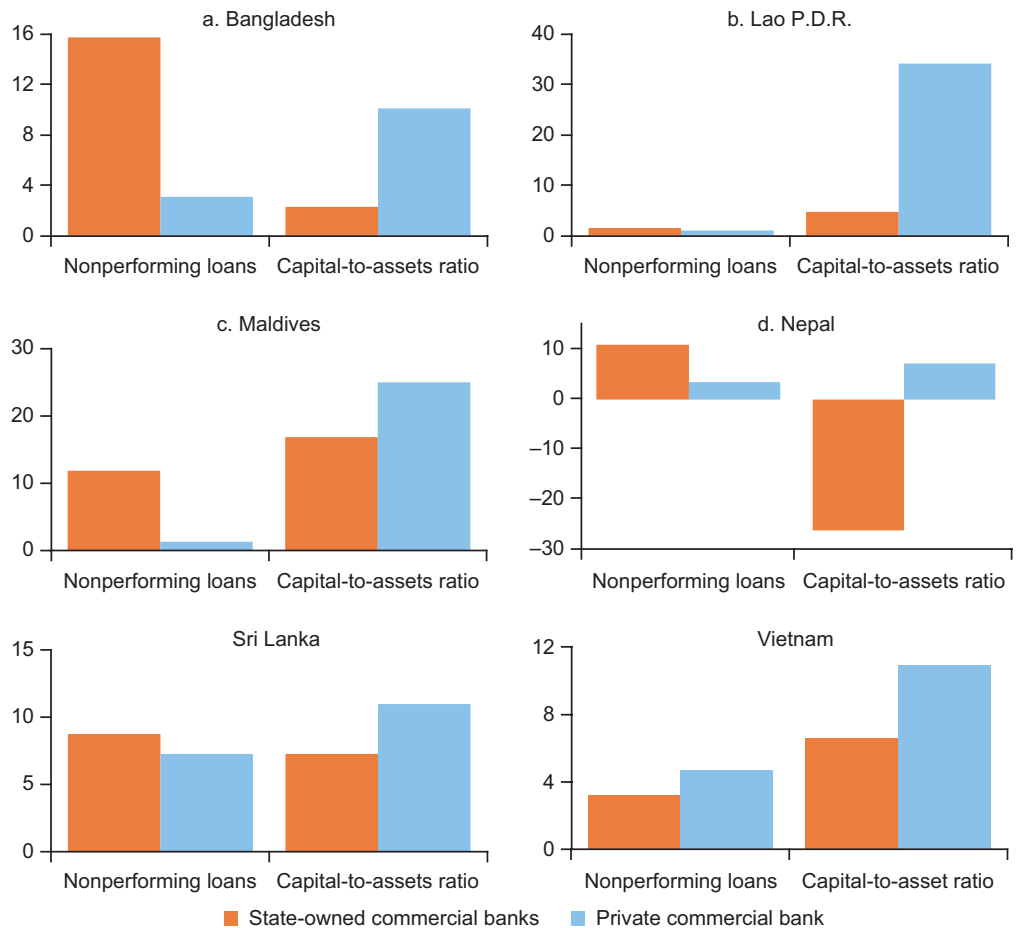

Figure 7.4 Relative Performance of State-Owned Banks in Asian Low-Income Countries (Percent, 2010 or latest available)

Sources: IMF, Article IV Reports, Financial System Stability Assessment Reports, Selected Issues Papers, and technical assistance reports.

as part of the financial system. Cross-border financial flows with correspondent banks are limited. Funding structures in frontier and developing Asian banks show little or no dependence on cross-border wholesale funding. However, there are notable exceptions: in Cambodia and Papua New Guinea, for example, foreign banks have a strong presence, reflecting the relatively underdeveloped state of domestic institutions and the authorities' approach to financial liberalization.

- Nonbank financial institutions: Credit cooperatives and other shadow banking firms are not as common as banks. However, in some frontier and developing Asian economies, these institutions have gained significance, and they are less regulated than commercial banks and other larger entities (Box 7.2). Nepal, for example, has some 26,000 credit cooperatives. Although each is small, they collectively represent assets of more than 7 percent of GDP and are largely unregulated. Other countries in which the nonbank sector has been or is emerging as a concern include Papua New Guinea and Sri Lanka.

- Weak supervisory capacity: Supervisory capacity has not always kept pace with financial sector growth. The steady increase in financial assets,

\section{(C) International Monetary Fund. Not for Redistribution}




\section{BOX 7.1 State-Owned Commercial Banks: Issues and Challenges}

The relative share of state banks in frontier and developing Asian economies is varied and has been gradually declining in many countries, but assets often continue to grow in nominal terms (Figure 7.1.1). In Vietnam, the share of state-owned banks in banking system assets dropped to less than 40 percent (from more than 60 percent) between 2006 and 2012 , but total assets of these banks grew by about 10 percentage points of GDP to more than 85 percent of GDP before declining amid financial stress (Figure 7.1.2).

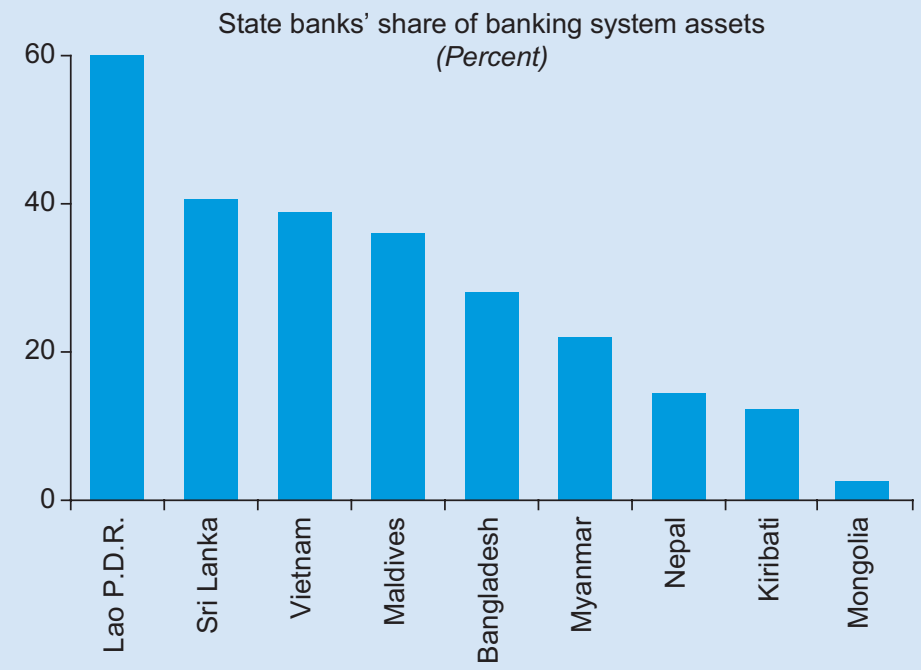

Figure 7.1.1 Frontier and Developing Asian State-Owned Banks' Share of Banking Sector Assets

Sources: Central banks; and IMF, Article IV Reports, Financial System Stability Assessment Reports, and technical assistance reports.

Note: 2010 or latest available.

Although state banks can, in some cases, encourage financial access, in practice they often provide subsidized lending and directed credit, and frequently demonstrate poor collection from connected individuals or state enterprises-giving rise to a negative relationship between economic growth and state ownership of banks. Relative to their private counterparts, state banks tend to be less well capitalized and less profitable, and have thinner core earnings. Several studies show the way in which state ownership of banks can impact economic growth, bank performance, financial sector reform, and monetary policy transmission.

Growth: State ownership of banks has been linked to lower economic growth through its impact on productivity resulting from the inefficient allocation of resources. Studies have shown that this relationship depends on a country's financial development and political institutions (La Porta, Lopez-de-Silanes, and Shleifer 2002; Körner and Schnabel 2010). In industrial countries, no correlation appears between state ownership and growth, but state ownership of banks in developing economies can weaken growth when accompanied by low financial development and institutional quality: an increase in public ownership of banks by 10 percentage points is associated with a reduction in the annual growth rate of per capita GDP of 0.12 of a percentage point. 


\section{BOX 7.1 (Continued)}

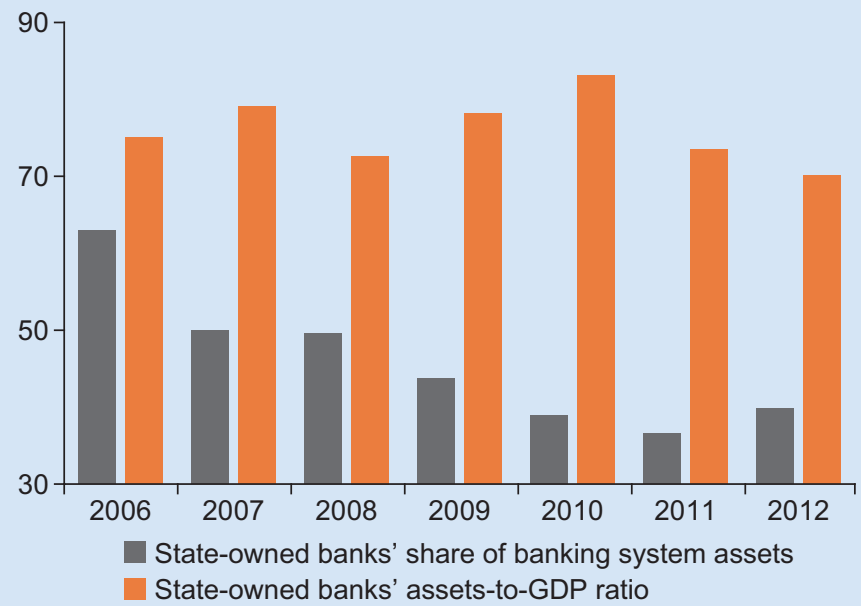

Figure 7.1.2 Vietnam: market share and asset size of state banks (Percent)

Source: State Bank of Vietnam.

Bank performance: Studies suggest a negative relationship between public ownership of banks and indicators of banking sector development and performance. One study, based on about 50,000 observations from 119 countries during 1975-2002, demonstrated that state-owned banks in developing economies are significantly associated with lower profitability and higher costs, even after controlling for other variables (Levy-Yeyati, Micco, and Panizza 2007).

Quality of financial sector reform: Government ownership can also affect financial sector reform and liberalization. Research has focused on how bank ownership can affect credit to the private sector after reform. One study, using bank-level data for 1991-2007 in India, explores whether public and private banks used resources freed up by reduced state preemption (measured by the requirement to hold government securities as a share of assets) to increase private credit (Gupta, Kochhar, and Panth 2011). The study finds that public banks allocated a larger share of assets to government securities than private banks because of the distortion in the incentive structure and moral suasion.

Monetary policy transmission: State ownership may complicate weak monetary policy transmission in developing economies. Research suggests that at lower levels of financial development, transmission is generally dominated by bank lending (Mishra, Montiel, and Spilimbergo 2010). However, weak institutions and high levels of bank concentration may undermine the transmission of central bank monetary policy actions to bank lending rates. Where state banks lend to state enterprises, political economy considerations can also complicate implementation of monetary tightening, implying the need for a more pronounced tightening of private credit. Bangladesh and Vietnam have faced such challenges in the past. 


\section{BOX 7.2 Rise of Nonbank Financial Institutions and Accompanying Challenges}

Nonbank financial institutions (NBFIs) are important complements to mainstream banking in many frontier and developing Asian economies. ${ }^{1}$ In most of these economies, NBFls in aggregate are still small relative to the size of the commercial banking sector and in comparison with the NBFI sector in major emerging market economies in the region, except in the case of the island nations of Papua New Guinea and Sri Lanka (Figure 7.2.1). Given limited access to commercial banking for some segments of the population and underdeveloped financial markets, finance companies (Bangladesh, Maldives, Mongolia, Nepal), microfinance institutions (Bangladesh, Cambodia), and contractual savings institutions (Bhutan, Papua New Guinea, Sri Lanka) play important roles in providing financial services. Insurance penetration, however, remains low across the frontier and developing Asian economies. Since 2000, NBFls have also undergone consolidation, and in some instances, a few of these institutions were converted to banks (Bhutan, Mongolia, Nepal).

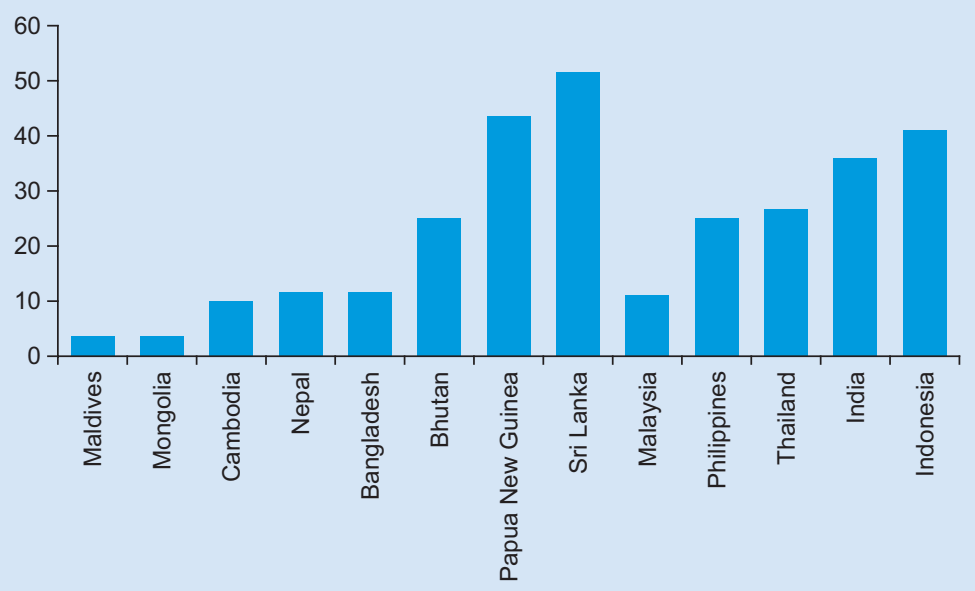

Figure 7.2.1 Size of the Nonbank Financial Sector (Percent of assets of commercial banking sector; latest available data)

Sources: Asian Development Bank (2011); country authorities; and IMF, Financial System Stability Assessment Reports.

Supervision and regulation of NBFls are fragmented across regulatory bodies. In countries with a single supervisor for the NBFls, central banks are assigned the role (Bhutan, Maldives, Papua New Guinea), except in Mongolia, where the Financial Regulatory Commission, set up in 2006, regulates the sector. In other frontier and developing Asian economies, central banks supervise and regulate some of the deposit-taking NBFIs, and there are often regulatory bodies for the insurance sector, microfinance institutions, rural banks and cooperative societies, and merchant banks and stock brokers. Supervisory capacity remains limited and often does not keep pace with growth in the NBFI sector. However, new laws have further empowered the supervisory authorities (Bangladesh, Maldives, Mongolia, Sri Lanka), but scope still remains for improving prudential and risk-based supervision in all frontier and developing Asian economies. The rapid proliferation of NBFIs has also raised concern about the effective supervision of their internal control processes. To the extent that not all deposit-taking institutions are supervised and regulated by the central bank, attempts should be made to establish a joint supervisory council to assess and minimize the risks to financial stability. Bangladesh and Mongolia, for example, have such joint supervisory bodies. 


\section{BOX 7.2 (Continued)}

Credit and operational risks remain the biggest vulnerabilities for the NBFI sector. Undiversified economic structures, underdeveloped legal frameworks related to credit information bureaus and collateral registries, and inadequate internal controls at these institutions pose big risks. Vulnerabilities in the banking industry could potentially spill over to the NBFI sector given that these institutions are often heavily reliant on the banks for funding and investment purposes. Weak regulation of the sector in some countries makes it an easy conduit for risky investment by banks and for money laundering.

${ }^{1}$ The definition of the NBFI sector varies by country. In this box, the NBFI sector is defined to comprise specialized development finance institutions, rural banks, leasing companies, investment and brokerage companies, housing finance companies, merchant banks, thrift and cooperative credit societies, contractual savings institutions (provident funds and insurance companies), and microfinance institutions.

activities, and instruments has been one challenge. In some frontier and developing Asian economies (where licensing has been more liberal) the sheer number of new institutions has outstripped supervisory resources. Most central banks have been hard-pressed to attract and adequately train supervisory staff. In Nepal, the number of bank supervisors has remained relatively steady since 2000, while the number of institutions (commercial banks, development banks, and finance companies) regulated by the central bank has more than doubled. Many countries also need to strengthen capacity (resources as well as technical skills) for adequately regulating and supervising a growing number of nonbank financial institutions (NBFIs).

\section{BANKING SECTOR PERFORMANCE}

Banking sector performance in frontier and developing Asia has varied, depending, in part, on how the financial sector in each economy has evolved. In many cases, rapid growth has resulted from market liberalization, economic growth, and increasing trust in financial institutions. In others, external factors (such as capital flows, remittances, or surges in commodity earnings) have helped to fuel a boom in financial institutions.

Many frontier and developing Asian economies have experienced strong growth both in bank deposits and in assets. Deposit mobilization and credit growth have been rapid, rising at an average annual rate of 31 percent between 2003 and 2013. As a share of GDP, private sector credit more than doubled in a number of frontier and developing Asian economies (Bhutan, Cambodia, Lao P.D.R., Maldives, Mongolia, Vietnam) and showed strong growth in most others (Figure 7.5). Vietnam's rapid financial sector growth has been the most visible, with growth in private credit more than double the next most significant case (Maldives-Figure 7.6). 


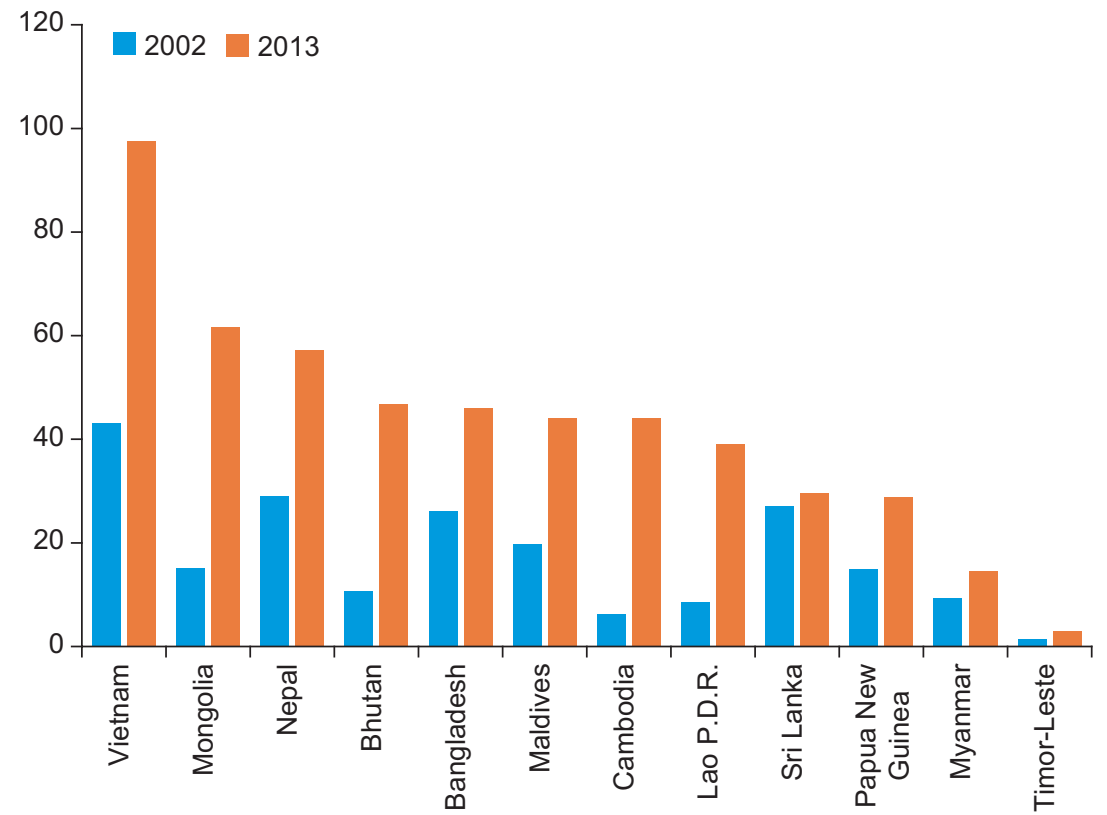

Figure 7.5 Ratio of Private Credit to GDP, 2002 and 2013

Sources: IMF, country desk data, and World Economic Outlook database.

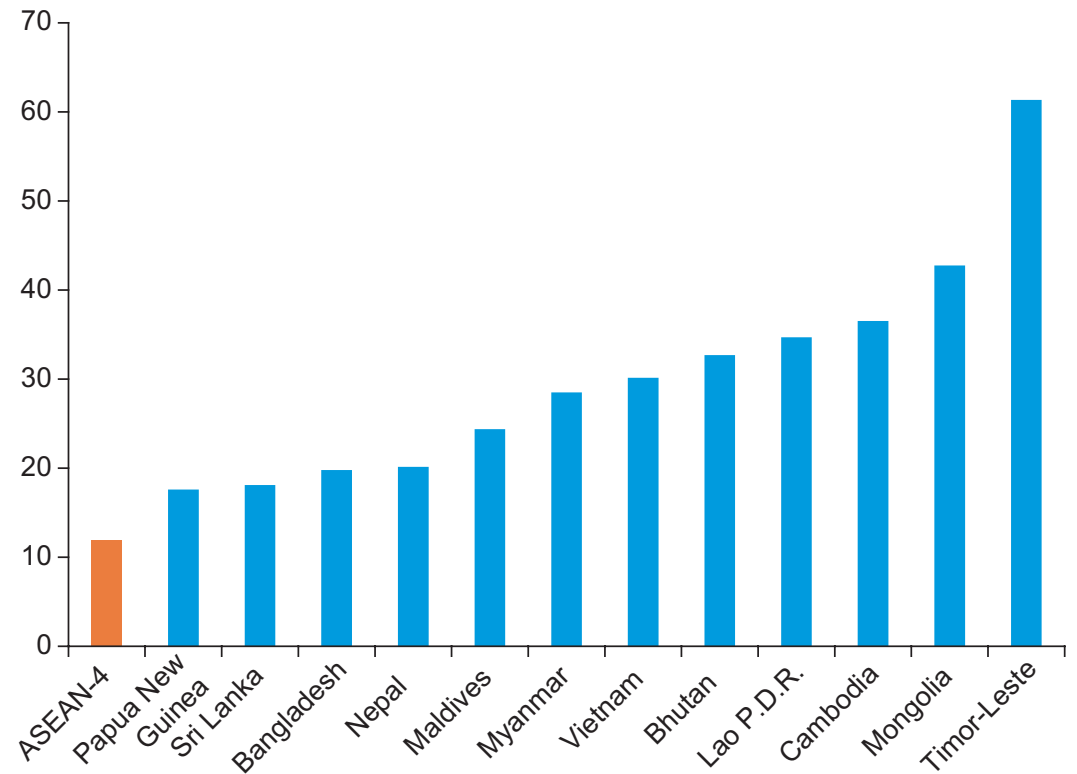

Figure 7.6 Average Annual Growth of Private Sector Credit, 2003-12

Sources: IMF, country desk data, and World Economic Outlook database.

Note: ASEAN-4 = Indonesia, Malaysia, Philippines, and Thailand. 
a. Return on assets

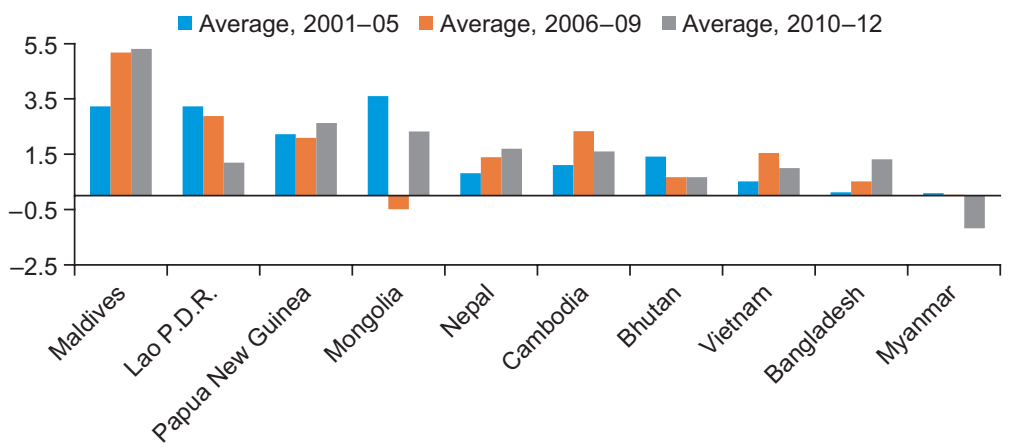

b. Return on equity

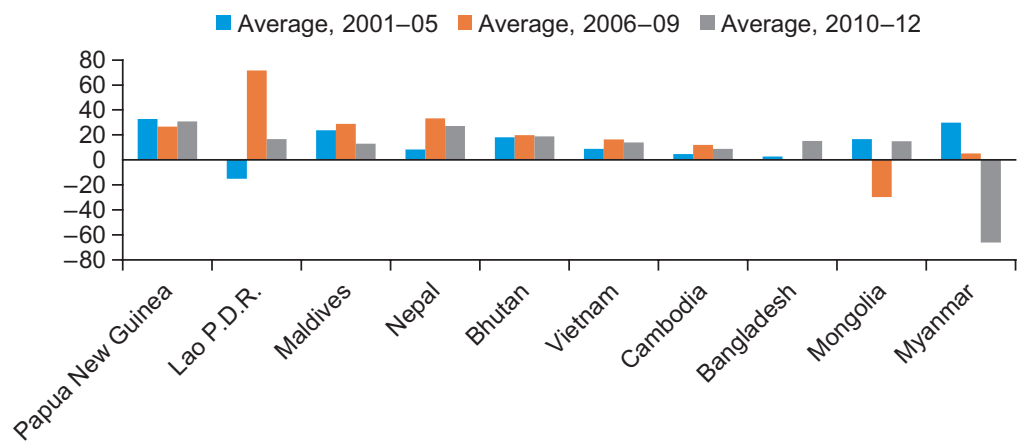

Figure 7.7 Bank Profitability

Sources: Central bank data; and IMF, Article IV Reports, and Financial System Stability Assessment Reports.

Profitability in frontier and developing Asian banks has varied-being largely idiosyncratic and subject to key domestic developments (such as commodity booms and busts, housing bubbles, and others-Figure 7.7). Average return on assets, for example, hovered around 1.6 to 1.7 during 2001-12, although there have been notable fluctuations for individual countries.

Rapid credit growth has raised the risk of poor quality of investment, as evidenced by shifts in asset quality. NPLs climbed in most frontier and developing Asian economies during the years of the global financial crisis (Figure 7.8). ${ }^{2}$ For a few, this increase in NPLs reflected exposure to global markets and interconnectedness with foreign financial institutions (Ree 2011). For most others, the impact of the crisis was indirect-for example, through declining remittances or a slowdown in such sectors as trade, tourism, services, or construction and real estate.

\footnotetext{
${ }^{2}$ Cross-country comparison of NPLs is hampered by varying accounting standards and quality of enforcement and is here meant to be illustrative.
} 

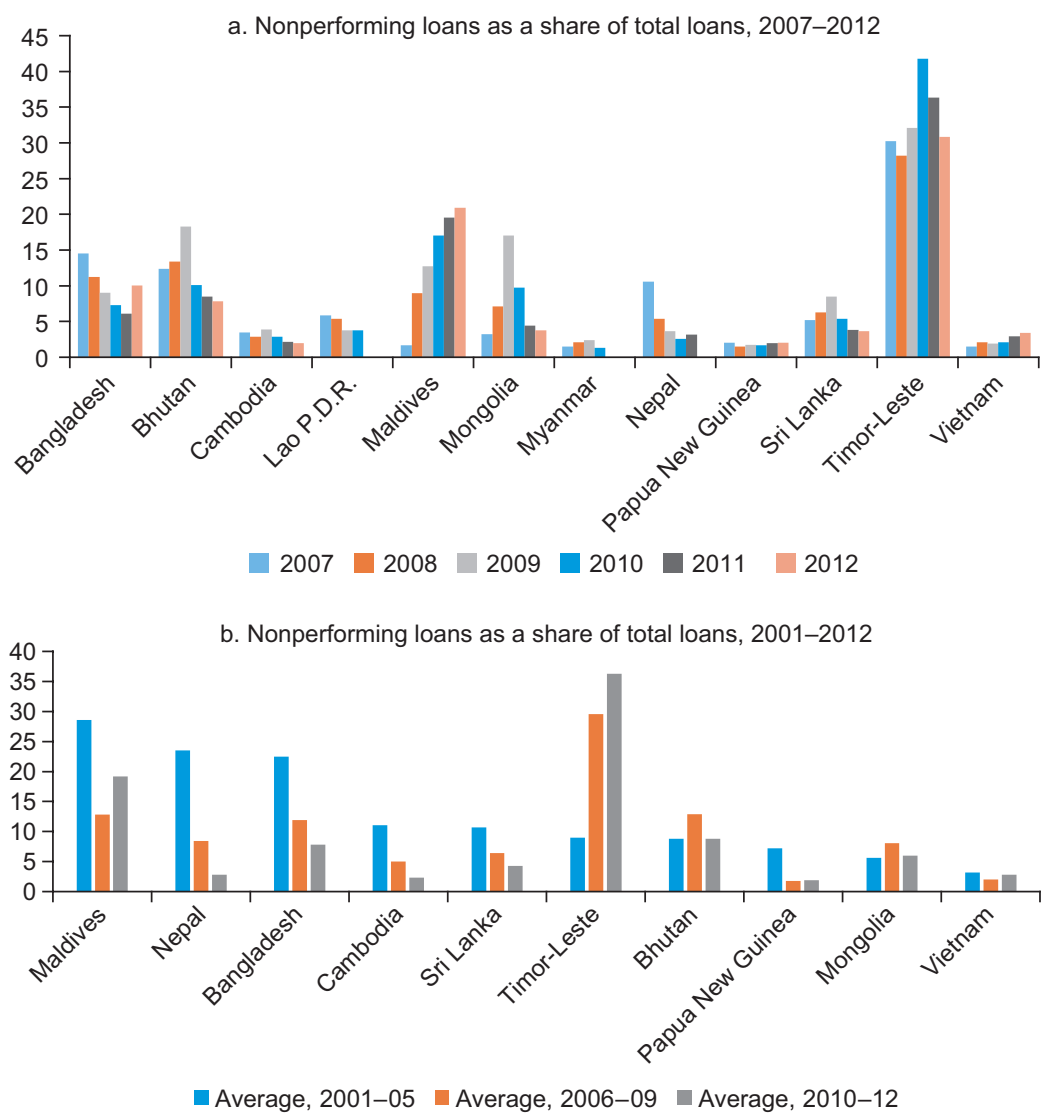

Figure 7.8 Frontier and Developing Asia Banks: Nonperforming Loans as Share of Total Loans

Sources: Central bank data; and IMF, Article IV Reports, and Financial System Stability Assessment Reports.

The most dramatic increases were seen in Maldives and Mongolia. The former was linked to declines in the tourism sector (in which loan concentration was heavy), and the latter reflected a downturn in commodities (particularly gold).

Capital adequacy has also varied among frontier and developing Asian economies. The differences partly reflect existing prudential regulations (some countries simply demand a higher capital adequacy ratio, CAR, than others). Other factors, such as corporate governance, experience with state banks, regulatory forbearance, and a history of systemic shocks (and banks' use of reserve cushions) also play a role. CARs have improved in many frontier and developing Asian economies in the postcrisis years, but the data often mask underlying problems. Strong capital adequacy in Maldives, for example, might be overstated because of regulatory forbearance given to NPLs. In Nepal, capital adequacy among commercial banks as a group has only recently recovered to the minimum CAR of 10 percent, 
reflecting the insolvency of two large state-owned commercial banks (Nepal Bank Limited and Rastriya Banijya Bank-which are in the process of being recapitalized). Even in countries with CARs in line with regulatory requirements, capital might be overstated if accounting standards are not yet in line with international best practices, implying that banks might have less capacity to absorb shocks.

The quality of reported financial soundness indicator data remains an issue. Data quality concerns have been raised during surveillance in most frontier and developing Asian economies. Classification of NPLs is the most common weakness, with a direct bearing on provisioning, profitability, and bank capital. In some countries, even the officially reported data vary significantly, and market expectations range from 4 percent to 20 percent. Nepal's banking system, with its heavy exposure to a challenging real estate market and overstretched supervisory capacity, is another case for which reported data may not accurately reflect banks' balance sheet stress.

\section{RISKS AND VULNERABILITIES}

Rapid financial sector growth in frontier and developing Asia is indicative of financial deepening, but such rapid expansion also comes with risks. Frontier and developing Asian economies could be facing risks and might want to learn from the lessons of today's Asian emerging markets prior to the Asian financial crisis of 1997-99 (Box 7.3). As in these countries, supervisory bodies in most of frontier and developing Asia have faced many challenges_-even with relatively intensive technical assistance from the IMF, the World Bank, and other international financial institutions and bilateral donors. Financial sectors in these countries remain subject to a number of vulnerabilities, which can be categorized broadly into domestic (homegrown), spillover, and governance and supervisory risks. Appendix 7A provides a qualitative benchmarking of vulnerabilities and the policy response. The next section discusses some of these risks in more detail.

\section{Domestic Risks}

\section{Risky lending}

Many studies suggest that changes in the ratio of private credit to GDP have the best predictive power for banking crises and asset price busts because rapid credit growth is often associated with excessive risk taking (Borio and Lowe 2002, 2004; Borio and Drehmann 2009; Alessi and Detken 2009; Gerdesmeier, Reimers, and Roffia 2009). ${ }^{3}$ Two factors are most common:

- In frontier and developing Asian economies, rapid credit growth was associated with excessive loan concentration in particular sectors-primarily real

\footnotetext{
${ }^{3}$ The credit-to-GDP ratio works well partly because it behaves countercyclically; most risk measures underestimate risk during the upswing and overestimate it during the downswing. However, a study covering 107 countries finds that neither private sector domestic credit as a share of GDP nor domestic bank credit as a share of GDP provided an early warning of the 2008 crisis (Rose and Spiegel 2009).
} 


\section{BOX 7.3 Parallels between Frontier and Developing Asia and the Asian Crisis Countries of the 1990s}

Rapid financial sector expansion in frontier and developing Asia bears some important similarities to that of the ASEAN-4 (Indonesia, Malaysia, Philippines, Thailand) in the 1990s. The parallels are most striking with respect to the growth of credit, asset concentration, and weak supervision. Nevertheless, important distinctions are the degree of integration with international financial markets, the use of foreign funds to finance domestic lending, and growth models-including governments' involvement in resource allocation.

As credit growth in frontier and developing Asia rapidly increased, nonperforming loan (NPL) ratios became elevated. Similar to the ASEAN-4, frontier and developing Asian countries experienced rapid credit growth, with annual growth rates hovering above 25 percent (Figure 7.3.1, panel 1). Although credit growth in frontier and developing Asia has easedwhich contrasts with the accelerated credit expansion in the ASEAN-4 leading up to the crisis of the late 1990s-NPL ratios remain elevated (Figure 7.3.1, panel 2), comparable to those of the ASEAN-4 in 1996. Heavy exposure to a few sectors was also a key vulnerability in the ASEAN-4 (such as excessive real estate investments in Thailand) during the precrisis period, which echoes conditions in frontier and developing Asian economies such as Bangladesh, Cambodia, Mongolia, and Nepal. In tandem with credit booms, investment booms are also underway (Figure 7.3.1, panel 3).

Amplifying these growing financial risks, the financial systems are poorly supervised in frontier and developing Asia. The financial systems in the ASEAN-4 during the precrisis years were not well positioned to deal with credit shocks alongside external shocks following capital liberalization. Banking sectors in the ASEAN-4 were poorly regulated with loose enforcement and compliance, which resonates with current frontier and developing Asia. Country authorities showed a preference for mergers and consolidation to deal with insolvent institutions instead of addressing root problems-much as in Nepal, Vietnam, and other frontier and developing Asian economies today.

Nevertheless, international claims by foreign banks are still limited for most frontier and developing Asian economies. In the run-up to the crisis of the late 1990s, the ASEAN-4 came to be heavily dependent on short-term foreign bank loans, with the amount reaching about 40 percent of GDP. In contrast, international claims to frontier and developing Asia remain low, at about 10 percent of GDP (Figure 7.3.1, panel 4). Apart from Cambodia and Mongolia, foreign currency lending also remains small in frontier and developing Asia, limiting currency mismatch risks. Still, some countries have large exposures to international claims - particularly Maldives (about 20 percent of GDP) and Vietnam (about 25 percent of GDP). International claims on the nonbank private sector have also increased during the past decade (Figure 7.3.1, panel 5).

More important, the key difference is in contrasting growth models and the concomitant degree of government involvement in bank lending. The governments in the ASEAN-4 were heavily engaged in managing the allocation of financial resources-partly financed from overseas at low cost following capital account liberalization. Emphasizing economic growth, the governments adopted various investment-conducive policies, such as government guarantees, which facilitated private inflows to finance investment. A large amount of the funds, however, was channeled to unproductive, unprofitable businesses -in some cases to those with close political connections. In contrast, frontier and developing Asian economies have not yet shown such heavy, systemic government involvement in financial resource allocation, thereby mitigating systemic risks, although some countries, such as Vietnam, have very large state-owned banking sectors and rely on directed lending to state enterprises and favored sectors.

\section{CInternational Monetary Fund. Not for Redistribution}




\section{BOX 7.3 (Continued)}

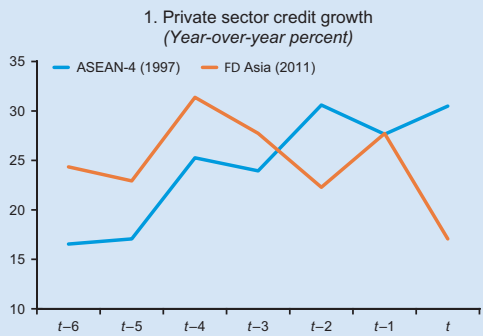

Sources: Corsetti, Pesenti, and Roubini (1998); and IMF staff estimates.

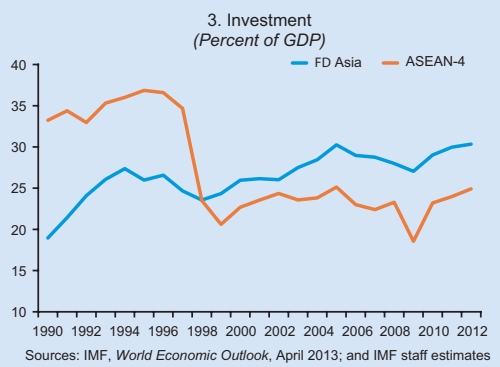

Sources: IMF, World Economic Outlook, April 2013; and IMF staff estimates.

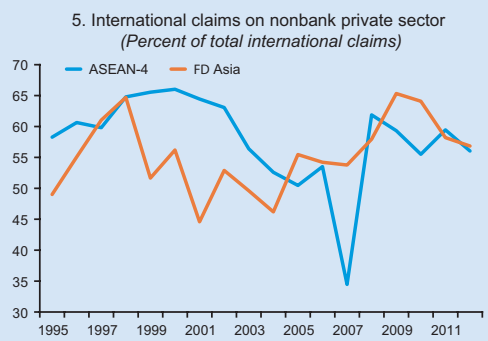

Sources: Bank for International Settlements, Consolidated Banking Statistics Table 9A (2013); and IMF staff estimates.

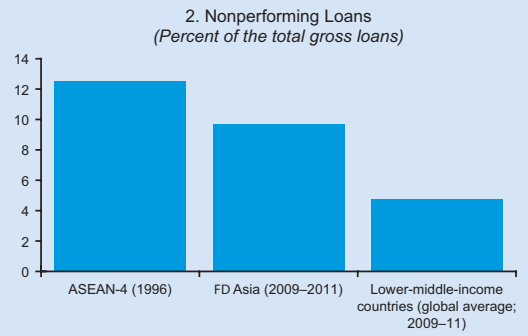

Sources: Corsetti, Pesenti, and Roubini (1998); World Bank (Financial Sector Data, 2013a); and IMF staff estimates.

4. International claims held by foriegn banks (Percent of GDP)

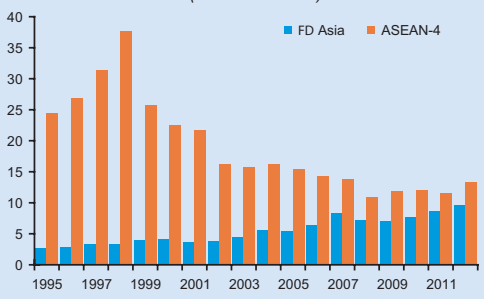

Sources: Bank for International Settlements, Consolidated Banking Statistics Table 9A (2013); IMF, World Economic Outlook, April 2013; and IMF staff estimates.

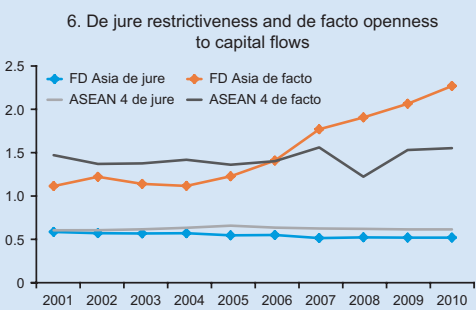

Sources: IMF and IMF staff estimates.

Note: The de jure index is based on estimates of the average ratio of restricted transaction categories in the capital account to the total number of transaction categories. The index ranges from 0 to 1 , with a decrease indicating greater openness. The de facto index is based on the updated Milesi-Ferretti de facto openness index, with an increase indicating greater openness.

\section{Figure 7.3.1 Comparison of Frontier and Developing Asia with ASEAN-4}

Note: FD Asia = frontier and developing Asia; ASEAN-4 = Indonesia, Malaysia, Philippines, and Thailand.

\section{(C) International Monetary Fund. Not for Redistribution}




\section{BOX 7.3 Parallels between Frontier and Developing Asia and the Asian Crisis Countries of the 1990s (Continued)}
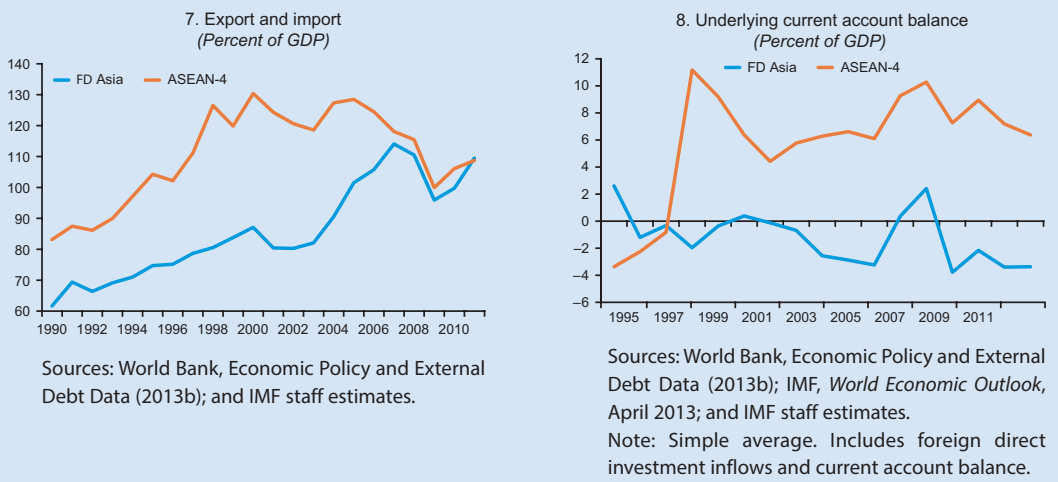

Figure 7.3.1 (Continued)

Frontier and developing Asian economies also exhibit limited openness and capital account liberalization, although they have become increasingly open since 2000 . The ASEAN-4 countries were relatively open-imports and exports as a share of GDP exceeded 110 percent in 1997. With the exception of Malaysia, capital accounts were also relatively liberalized to facilitate higher levels of investment. In contrast, frontier and developing Asian economies are generally less open as measured by trade flows, and some maintain capital account restrictions. Still, de facto openness of frontier and developing Asia is steadily rising, and trade flows have also jumped (Figure 7.3.1, panels 6 and 7). Similar to the ASEAN-4, which had large current account deficits in the mid-1990s, some frontier and developing Asian economies have posted widening underlying current account deficits (Figure 7.3.1, panel 8).

estate. In Nepal, this concentration contributed to a liquidity squeeze and fears of a potential banking crisis in 2011, when a sharp drop in real estate prices was accompanied by a slowdown in remittances growth. In Vietnam, booms and busts in the real estate market were a key factor behind credit cycles and rising NPLs.

- Concerns about concentration risk also arise from large exposures to single borrowers or to related parties — sometimes in breach of prudential regulations. In Papua New Guinea, banks have high loan exposures to single large borrowers whose fortunes, in turn, are largely dependent on volatile commodity prices. In several countries-Bhutan, Lao P.D.R., and Mongoliaexcessive credit growth has also heightened external stability risks: credit-fueled domestic demand increases import growth and puts additional pressure on foreign exchange reserves while accentuating currency mismatches on banks' balance sheets. 


\section{Interbank linkages}

Interbank contagion and multiple gearing: In a number of frontier and developing Asian economies (most notably Mongolia, Nepal, and Vietnam) rapid credit growth has been accompanied by an increase in cross-ownership in the banking system. These relationships consist of both mutual ownership among banks and cross-ownership between enterprises and banks. Although conglomeration offers advantages, such as greater financial capacity to withstand shocks and wider diversification of activities, it also poses special challenges for prudential regulation and supervision. In particular, cross-ownership makes it more difficult to detect and correct (1) multiple uses of existing capital (double or multiple gearing); (2) group risks (contagion, concentration, management complexity, and conflicts of interest); and (3) regulatory arbitrage (the shifting of certain activities or positions within a conglomerate to avoid stricter prudential rules and supervision by one set of supervisors compared with another, or to avoid regulation and supervision altogether by transferring the activities or positions to an unregulated entity).

The lack of transparency of cross-ownership among banks, and between enterprises and banks, is a particular area of concern. This lack of clarity could undermine lending standards and increase the risks of interbank contagion. Cross-ownership also raises concerns about conflicts of interest and about banks imprudently channeling funds to related companies or unrelated speculative ventures. An example of this could be that some shareholders may fund their share purchases via bank loans, including loans from the same banks in which they have invested. Such multiple gearing would make capital a circular relationship that poses an asset risk to the relevant bank or to the banking system as a whole, and could undermine the loss-absorption capacity of bank equity.

\section{Governance Risks}

Virtually all countries in frontier and developing Asia witnessed rapid credit growth in the context of weak corporate governance in banks. A significant number of domestic banks have inadequate internal audit and control systems and lack sound risk-management frameworks and practices to monitor and control the risk profiles of their loan (or, more generally, asset) portfolios. For example, banks in Myanmar (and to a lesser extent in Bhutan) have little experience with international standards of accounting and risk management. Political interference in banks' lending decisions in some countries-for example, Bangladesh - is a related governance risk, particularly in state-owned commercial banks. The result is that operational risks in the banking system are high in many of these countries; for example, the IMF's Financial System Stability Assessment of Papua New Guinea (IMF 2011b) notes that operational risks, including security and fraud risk, are material in a country in which violence and crime are significant. 


\section{Supervisory Risks}

Supervisory agencies in most frontier and developing Asian countries face common challenges. These challenges include a shortage of qualified staff, a lack of technical capacity, and data weaknesses that severely impair the quality of surveillance and supervision. Partly as a consequence, risk-based supervision is at an early stage of implementation in many of these countries. Banking supervision could be strengthened, since the emphasis is often on compliance with laws and regulations, particularly those related to attaining monetary policy objectives (such as interest rate controls or lending limits) at the expense of a clear focus on sound risk management of banking activities. Notable examples include Lao P.D.R., Mongolia, and Myanmar, where compliance-based supervision continues to be the norm, with limited efforts to move toward risk-based and forward-looking supervision.

Fragmentation, weak mandates, and lack of independence are also common supervisory challenges. In a number of frontier and developing Asian economies, semiautonomous bodies have overlapping jurisdictions and lack independence and clear mandates. Cooperation and exchange of information are often limited. In Cambodia, for example, a memorandum of understanding among supervisory agencies for coordination across supervisors and for exchange of information on cross-cutting issues is not yet fully developed. Multiple central bank objectives can also undermine supervision. In Vietnam, the law does not give the central bank a clear and unambiguous mandate to guard the safety and soundness of the banking system, which could have presented some challenges to supervision and enforcement in the past.

Work also needs to be done with regard to consolidated supervision and crossborder cooperation on regulation and supervision of financial institutions. None of the countries in frontier and developing Asia has a robust framework for conducting consolidated supervision. A Financial System Stability Assessment for Mongolia highlights implementation of consolidated supervision (as well as riskbased supervision) as a key priority for strengthening banking supervision and regulation (IMF 2011a). With the expansion of cross-border banking, another priority in several countries is to strengthen cross-border supervisory cooperation. Some frontier and developing Asian economies do not have memoranda of understanding with bank supervisors of all home countries of foreign banks with a large presence in their domestic financial markets.

\section{Legal and Regulatory Risks}

In a number of frontier and developing Asian economies, banking regulation and supervision frameworks have not kept pace with international standards; for example, the capital adequacy requirement in Vietnam might be based on Basel I but is not fully consistent with it, and the country has not yet adopted international financial reporting standards. Potential underreporting of NPLs is an important challenge in several countries. 
Enforcement of existing prudential rules lacks teeth in some frontier and developing Asian economies. The problem is particularly notable with regard to single-borrower limits and related-party lending. In Papua New Guinea, for example, the central bank lacks legal authority to impose administrative sanctions on banks that fail to comply with prudential regulations. In Maldives, regulatory forbearance extended by the central bank since June 2012 has led to an artificial boost in capital adequacy and provisioning, and several commercial banks remain out of compliance with prudential norms on single-borrower exposures and net open foreign exchange position limits. In Nepal, strengthening of prudential regulations by the central bank following the near-crisis in April-May 2011 gave way to some regulatory forbearance. IMF (2011a) notes that strict enforcement of regulatory requirements in Mongolia is lacking and that the central bank permits regulatory forbearance.

Few countries in frontier and developing Asia have formal and effective crisismanagement and bank resolution frameworks, including for the provision of liquidity and solvency support. Instead most of them have some components of a crisis-resolution framework, including an established means of providing shortterm liquidity support, longer-term solvency support, deposit insurance, and a legal and regulatory framework that can facilitate the restructuring or resolution of a problem bank or financial institution. In many cases, however, large gaps remain to be filled. Deposit insurance schemes are frequently in the early stages, and have limited resources. Liquidity and solvency support is provided on an ad hoc basis. And the legal framework supporting restructuring or liquidation of financial institutions is in need of strengthening or of separation from the general insolvency framework. Prompt corrective action frameworks, which would take much of the discretionary element out of intervention, are also frequently absent or not always observed.

\section{External and Spillover Risks}

Most frontier and developing Asian economies have relatively underdeveloped links with international financial markets. As in many low-income countries, the lack of direct links between frontier and developing Asia and advanced and emerging markets provided a buffer during recent global crises. In contrast with regional emerging market economies (particularly precrisis Asia in the 1990s), debt markets in most frontier and developing Asian countries remain largely unexplored by global investors (see Chapter 8). High and difficult-to-price sovereign risks and heavy reliance on concessional financing and foreign direct investment leave limited room for a market for external sovereign bonds to thrive. Moreover, domestic bonds attract few foreign investors, given stringent capital controls and uncertain exits, reflecting in particular a dearth of secondary trading as well as high repatriation risks. Banks' security holdings consist mainly of government and central bank debt, which is generally held to maturity. Crossborder ties (proxied by foreign bank claims-Figure 7.9) illustrate the 


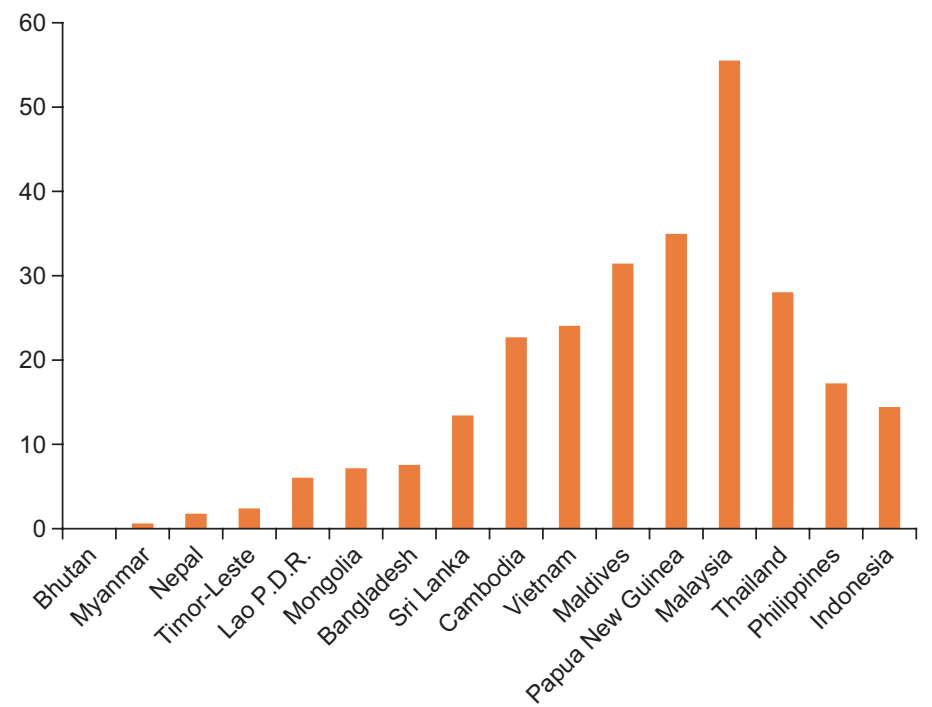

Figure 7.9 Consolidated Foreign Claims on Banks, as Share of GDP, 2012 (Percent of GDP)

Source: Bank for International Settlements.

comparatively weak links to international markets in a number of frontier and developing Asian economies (for example, Lao P.D.R, Mongolia, Myanmar, Nepal) compared with some emerging market economies. Other frontier and developing Asian economies (Cambodia, Maldives, Sri Lanka, Vietnam), which have a larger foreign bank presence, tend to have stronger links comparable to other Asian economies.

Comparatively insulated banking systems in many of these countries emerged from the crisis relatively unaffected by direct financial contagion. This outcome is markedly different from developing market counterparts during the Asian crisis of the late 1990s (see Box 7.3), in which a high degree of openness and weak oversight of nonbank activity facilitated rapid transmission of financial contagion. IMF surveillance in 2009-10 for virtually all of the frontier and developing Asian economies reported little or no direct financial contagion from the global crisis. Rather, indirect channels (commodities, remittances, and accompanying effects on property markets where banks were heavily exposed) were more common conduits for negative pressures.

The absence of direct financial links does not mean that frontier and developing Asian economies are completely immune to spillovers. Empirical work suggests an important difference between the largest banks in frontier and developing Asia, which show some sensitivity to international market turbulence (mainly through cross-border funding) and smaller banks that remain insulated and dependent primarily on domestic conditions (Box 7.4). 
BOX 7.4 Impact of the Global Financial Crisis on Frontier and Developing Asian Financial Sectors

An IMF study (Ree 2011) examined the impact of the global financial crisis on a subset of frontier and developing Asian countries (Bangladesh, Cambodia, Lao P.D.R., Mongolia, Sri Lanka, Vietnam). Most frontier and developing Asian economies were insulated from the direct effects of the crisis by their isolation and sparse links with international financial markets (even more so for Bhutan, Myanmar, Nepal, Papua New Guinea, and Timor-Leste). However, despite this low level of integration, there is evidence of pass-through to frontier and developing Asian banks - particularly to large ones. And the effects of the global crisis were most strongly transmitted through a loan-to-cross-border-funding nexus-most visibly for the 20 largest banks.

Market risk showed little measurable impact, with frontier and developing Asian banks continuing their strong mark-to-market gains despite the global financial crisis. The lack of spillover through exposure to market risks is likely due to frontier and developing Asia's comparatively low degree of financial market integration. By contrast, Asian emerging market banks' balance sheet linkages to global financial markets proved significant. Philippine banks took the hardest hit, with 0.6 percent of the value of their average assets eroded by mark-tomarket loss, followed by Indonesian banks (mark-to-market losses at 0.2 percent of average assets) and Malaysian banks (mark-to-market gains slipped 0.1 percent of average assets).

The impact on funding and lending is less clear. On the funding side, frontier and developing Asian banks as a whole did not appear to be affected-especially compared with Asian emerging market banks. On a more disaggregated level, however, some evidence indicates that wholesale funding sharply decelerated in 2008 in the 20 largest banks in the frontier and developing Asian economies reviewed, followed, however, by a strong rebound in 2009. Smaller banks in the Asian low-income countries continued to expand their wholesale funding in 2008 and 2009, although at an increasingly slower pace than in 2007. The proportion of the deceleration in wholesale funding that can be attributed to global capital flow factors is not obvious, and the cycle of cross-border interbank capital flows to these countries was less uniform than in emerging market counterparts. With respect to lending, the aggregate data are again split-the top 20 banks allowed lending growth to plunge by 21 percentage points to 8 percent in 2008, while smaller banks maintained their lending growth at 20 percent. By contrast, the top 20 Asian emerging market banks strove to sustain their lending growth despite a sharper drop in deposit growth. The difference in initial liquidity buffers appears key to determining the vigor with which banks leaned against the wind in this period.

With respect to asset quality, the median nonperforming loan (NPL) ratio of frontier and developing Asian banks stayed unchanged from the previous year at 3.6 percent in 2008, before shedding 0.9 percentage point in 2009, despite significant deceleration of economic growth. However, a disaggregated view of the data suggests that the Asian low-income country banks may have suffered a somewhat greater spillover from the crisis on NPLs. NPL ratios for the top 20 low-income country banks were far less likely to rise in 2008 than those of all frontier and developing Asian banks and more likely to decline in 2009. This dichotomy may reflect better credit risk management on the part of these banks, or a greater tendency toward regulatory forbearance of delinquency based on their more favorable liquidity.

These findings caution against understating frontier and developing Asian banking systems' vulnerability to international liquidity and capital flow cycles. Even though vulnerabilities appear to be significant and to be growing, macroprudential supervision is generally nascent or nonexistent. As a starting point, compiling and disseminating data on interbank capital flows can be stepped up to inform the use of countermeasures, including prudential regulations or capital controls, as needed. Currently, Bank for International Settlements (BIS) capital flow data are the only regularly disseminated information on this front, but the data gap may be particularly significant for frontier and developing Asian economies given their large exposures to Chinese and other intraregional capital flows, which are not captured well by the BIS statistics.

\section{CInternational Monetary Fund. Not for Redistribution}


As frontier and developing Asian economies liberalize, make progress in macroeconomic management, and generate greater interest from investors, external links will invariably grow. This interconnectedness brings opportunities, but will also heighten risks from the preexisting vulnerabilities reviewed above. Therefore, the entry of foreign banks into a developing market economy raises both opportunities and risks (Box 7.5). Foreign bank entry in various forms can help transfer technology and managerial expertise and can foster competition, thereby improving financial services and promoting more rapid development of the financial sector. However, foreign bank entry - if premature-risks overwhelming weak supervisory capacity and may force out of business some domestic institutions that are at a financial, technological, or managerial disadvantage, even if they have superior local knowledge. Foreign banks may also attract the stronger clients (firms and individuals), leaving the domestic banking sector with weaker clients. Different approaches to foreign bank entry are possible with regard to speed and models of entry (Box 7.5). Regardless of the approach, however, a number of regulatory and supervisory conditions are needed to ensure that foreign bank entry is consistent with financial sector stability (see Appendix 7C for a review of bank entry conditions).

\section{COUNTRY PROGRESS IN ADDRESSING CHALLENGES}

Frontier and developing Asian economies have made progress in improving the key pillars of financial sector supervision since the mid-2000s. The rate of progress has varied, with some making a more concerted effort to deal with vulnerabilities and challenges. Others have taken a more gradual approach, reflecting a mix of capacity constraints and preferences with respect to oversight of financial institutions (Barth, Caprio, and Levine 2004). But generally, interest in improving oversight and reducing financial sector risks is clear in most frontier and developing Asian economies.

Proxy data are indicative of frontier and developing Asian economies' levels of interest in and commitment to addressing financial sector vulnerabilities. For example, most of these countries have financial sector reform plans-homegrown initiatives to address vulnerabilities or move financial sector supervision and regulation closer to international standards. Nearly all frontier and developing Asian economies are intensive users of IMF technical assistance: financial sector technical assistance is the leading form of assistance in about half (Appendix 7A). Assistance from the World Bank also figures prominently in most of these countries' financial sector reform efforts.

Most frontier and developing Asian economies have made improvements in the quality and timeliness of supervision — often by tightening existing prudential criteria or restructuring supervisory processes. Many have also undertaken reforms to the legal framework (usually through central bank or commercial bank laws) with a view to clarifying mandates, roles, and supervisory powers. Some 


\section{BOX 7.5. Cross-Country Experience with Foreign Bank Entry}

Asian economies have followed various approaches to foreign bank entry with respect to speed and model, suggesting several considerations for frontier and developing Asia. (For a detailed description of these approaches, see Appendix 7B.)

Speed: Indonesia, the Republic of Korea, and Thailand quickly initiated reforms to allow foreign bank entry in the aftermath of the Asian financial crisis of the late 1990s as part of a comprehensive set of liberalization efforts. The Philippines also liberalized foreign bank entry substantially after the Asian crisis, but at a somewhat slower pace. China and India pursued a more gradual approach. For China in particular, the timing and manner of foreign entry were mostly driven by World Trade Organization accession obligations. ${ }^{1}$ Among frontier and developing Asian economies, Lao P.D.R. and Vietnam pursued a gradual approach; Cambodia allowed foreign bank entry with few restrictions during the comprehensive conversion from the monobank system.

Model of entry: Gradual increases in foreign equity shares in banks have been common, but ceilings range from 30 percent in Malaysia to 100 percent in Korea. Market access for branches differs from that for subsidiaries. Malaysia allows subsidiaries only, while other countries allow both branches and subsidiaries. Korea allowed foreign branches and ownership stakes in local banks first, followed by subsidiaries. China allowed foreign equity in local banks before subsidiaries and branches. Thailand allowed ownership by foreign banks followed by subsidiaries and branches simultaneously. In frontier and developing Asia, Cambodia permitted all forms of foreign participation simultaneously, while Vietnam followed an approach similar to China's. Lao P.D.R. allowed joint venture (JV) banks and branches simultaneously, but not subsidiaries. Maldives allowed four foreign branches starting in the mid-1970s and subsidiaries later.

Level of financial liberalization: Some Asian economies maintained substantial financial restrictions even after foreign bank entry. Among frontier and developing Asian economies, Lao P.D.R. and Vietnam had relatively low levels of financial liberalization, while Cambodia, which followed a "big bang approach," liberalized the financial system and allowed foreign bank entry at the same time. Bangladesh nationalized domestic banks following independence, but permitted existing foreign branches to continue to operate.

\section{Advantages and Disadvantages of Different Strategies}

Joint ventures followed by foreign subsidiaries and branches: The advantages of this approach include (1) "breathing room" to develop and upgrade skills at domestic banks and to prepare for foreign competition; (2) technology and skills transfer, especially if JV requirements include a critical mass of foreign executives and specialists; and (3) a less onerous and gradual overhaul of regulations and supervision. Disadvantages may include potentially less deployable capital and credit compared with fully owned branches or subsidiaries, slower diffusion of technology, and lack of interest by foreign banks if ownership control is not sufficient.

Big bang - fully owned foreign branches or subsidiaries and JVs: The advantages to the big bang approach can include faster progress in modernizing financial services through competition and potentially greater access to credit for borrowers. Potential disadvantages include the inability of some domestic banks to withstand foreign competition and concentration of relatively safer business at foreign banks, leaving domestic banks to focus on riskier activities.

Branches or subsidiaries? Although there is not a significant difference with regard to financial stability, ${ }^{1}$ the operational modalities of branches versus subsidiaries could have implications. For instance, foreign bank branches rely on the parent's balance sheet for funding and service provision on an ongoing basis, while subsidiaries' dedicated local capital may affect their capacity to expand or contract operations. If not domestically permitted, foreign bank branches may find it easier to transfer certain activities to parents in offshore markets, thereby limiting domestic banking development. In addition, by ringfencing their local capital, subsidiaries could be better shielded from potential problems of the parent if the parent were to face an adverse shock.

${ }^{1}$ For more details see IMF (2011d). 
have also sought to improve financial sector infrastructure, such as deposit insurance and credit registries.

Areas for further reform center largely on the timeliness and quality of financial soundness indicators, supervisory capacity, prudential frameworks, and countries' ability to deal with financial sector crises. The most pressing areas for reform include the following:

- Improving the quality of financial soundness indicators and the capacity of financial supervisory bodies to collect this data.

- Strengthening loan classification practices and enforcement of prudential standards.

- Bolstering supervisory capacity-both the absolute levels of manpower needed to oversee growing financial sector activity and the capacity of financial supervisors to assess and effectively act when it comes to risky or problematic institutions.

- Building capacity to monitor macroprudential indicators and financial system stress, as part of a broader effort to bolster supervision and provide for earlier action to circumvent crises; considerable headway has been made in this regard in emerging and more advanced economies, but such efforts could also be pursued in frontier and developing Asia (Box 7.6).

- Enhancing surveillance of nonbank financial institutions, particularly where NBFIs are not subject to sufficient oversight or regulation.

- Establishing effective crisis-management and bank resolution frameworks, including for prompt remedial action.

\section{BOX 7.6 Predicting Financial Sector Distress}

Early recognition of financial sector vulnerabilities and stress is key to avoiding crises. Several macro-financial indicators can help highlight the buildup and realization of phases of systemic risk. Based on a sample of 40 countries with 76 instances of financial sector distress (IMF 2011d), these indicators include the following:

- Increases in the credit-to-GDP ratio (either bank credit or a broader measure that also includes cross-border loans to domestic nonbanks) of more than 3 percentage points, year over year, could serve as early warning signals one to two years before a financial crisis. Postdistress, this measure falls sharply.

- Credit-to-deposit ratios higher than 120 percent are associated with crises within the following year.

- Private sector foreign liabilities typically accelerate rapidly before a crisis. External borrowing by banks and the nonbank private sector grows from about 10 percent to 25 percent in the run-up to financial stress.

- Banks' foreign liabilities as a fraction of domestic deposits increase from about 32 percent to 38 percent two years before a crisis. 


\section{BOX 7.6 (Continued)}

- Real effective exchange rates tend to appreciate rapidly in the run-up to a crisis in emerging market economies.

- House prices, on average, tend to rise by 10 to 12 percent for two years before financial sector stress.

These indicators are based largely on a sample of advanced and emerging market economies. Their applicability to developing economies is not entirely clear-particularly where market forces are weaker and the evolution of financial crises tends to move more slowly. A more precise set of benchmarks geared to low-income countries is needed, but using the above indicators yields some findings of note for frontier and developing Asia.

All frontier and developing Asian economies have seen at least one year of credit-to-GDP growth in excess of 3 percent (Figure 7.6.1, panel 1). In Vietnam (which has faced some difficulties since 2009) this growth is the most pronounced, with an average increase of 6 percent a year between 2002 and 2012.

With the exception of three countries, frontier and developing Asia has not seen credit-todeposit ratios breach 120 percent. Vietnam's credit-to-deposit ratios were well in excess of this threshold between 2002 and 2012-followed by Maldives, Mongolia, and Sri Lanka in the $80-90$ percent range.

Private sector liabilities remain limited compared with Asian emerging market economies (as discussed earlier).

Real effective exchange rates have varied. During the past decade (since 2002), virtually every country in frontier and developing Asia has seen significant real effective exchange rate appreciation (Figure 7.6.1, panel 2). Since 2007, however, appreciation has been more moderate for most.

Real estate booms have been seen in Bhutan, Cambodia, Mongolia, Nepal, and Vietnam. In most of these countries, surges in housing and real estate prices and bank exposure to these sectors have been cited as factors in financial sector distress or as a potential vulnerability.

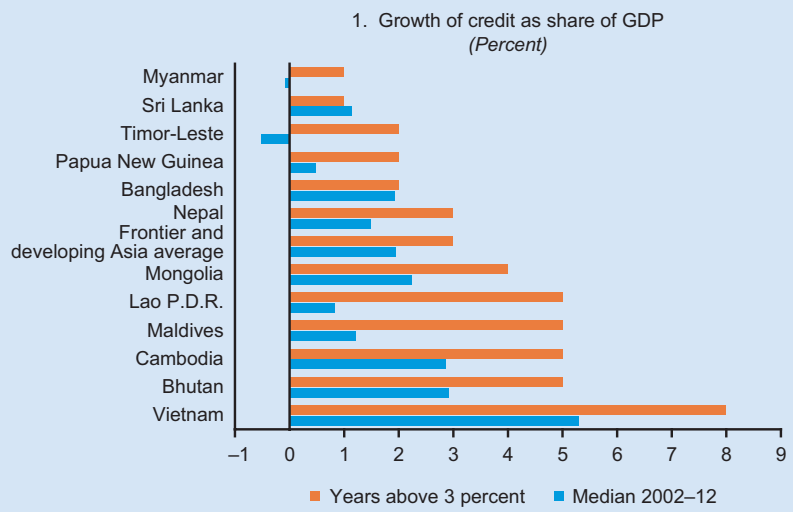

Figure 7.6.1 Signs of Potential Distress in the Financial Sector Sources: IMF, country desk data; and World Economic Outlook database.

\section{(C) International Monetary Fund. Not for Redistribution}




\section{BOX 7.6 (Continued)}

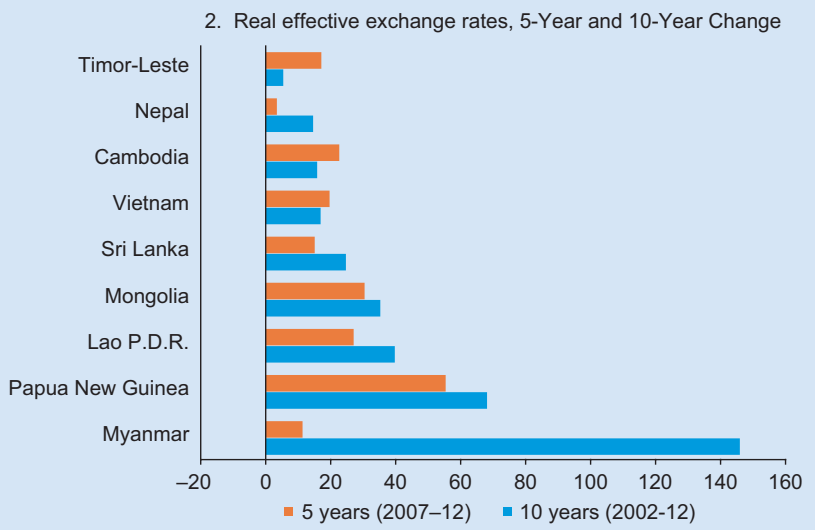

Figure 7.6.1 (Continued)

\section{POLICY RECOMMENDATIONS}

Policy recommendations for financial sector reform need to be country specific and tailored to meet both needs and existing capacity. The countries examined in this chapter cross the spectrum of financial sector development. Common threads of vulnerability in frontier and developing Asian economies suggest a few areas for which policy focus is particularly warranted.

Enhancing data collection and analysis: Virtually all frontier and developing Asian economies have significant shortcomings in the quality and timeliness of data for financial soundness indicators. A focused effort to improve financial soundness indicator data collection, backed by a more rigorous application of international financial reporting standards, is essential. Initiatives in support of such efforts are critical if data and accounting are to improve to a degree sufficient not only to ensure effective supervision and prevention (or mitigation) of financial crises, but to instill the confidence needed for successful deepening of financial intermediation.

Building effective supervision: Supervisory resources appear inadequate relative to the size and growth rate of the financial sectors in many frontier and developing Asian economies. Capacity - the ability to undertake effective on- and off-site supervision and to accurately assess the level of risk in financial institutions or the financial system as a whole-also appears weak despite notable improvements in a number of these countries and intensive technical assistance from the IMF, the World Bank, and other international financial institutions and donors. Looking ahead, foreign bank entry and presence will also require additional supervisory skills and resources. The issue of enforcement-bringing noncompliant institutions in line with prudential standards - also remains. Enforcement is often undermined by political economy considerations; forbearance can be a product of 
relatively weak supervisory authorities facing powerful vested interests (including state-owned commercial banks).

Bringing prudential standards in line with international good practice: Weak or antiquated prudential standards are a common problem in frontier and developing Asia, particularly where the growth of banking activities and financial markets has outpaced supervision and regulation. This problem is not specific to frontier and developing Asia, but is compounded by strong economic growth and rapid financial sector deepening. In a number of these countries a quantum leap is needed to address existing weaknesses.

Establishing an effective framework for crisis resolution: The global financial crisis has highlighted the importance of establishing strong financial safety nets, but few countries in frontier and developing Asia have done so as yet. The norm has instead been to rely on mergers and ad hoc measures to deal with problem banks, as has been the case, for example, in Vietnam. In Cambodia, work on key elements of a crisis-management framework has not yet been initiated, and agreements on the delineation of responsibilities among different supervisory agencies are still pending. And even though the bank resolution regime in Sri Lanka has been effective, a comprehensive institutional and legal framework for tackling a systemic banking crisis has yet to be developed. Finally, most countries in frontier and developing Asia do not have financially viable deposit insurance schemes.

Creating or strengthening the supervisory framework for NBFIs: In many frontier and developing Asian economies, the nonbank financial sector remains small but has the potential to expand quickly and outside the supervisory umbrella. Thus, oversight of this sector needs to be significantly enhanced. Equally important, the supervision regime needs to be adequate to effectively oversee and evaluate the risks associated with banks' participation in "nonbank" activities.

Another priority in many frontier and developing Asian economies is to strengthen the monitoring of systemic risks and to enhance the framework for macroprudential supervision. This is particularly important for countries with significant cross-ownership issues, and almost all IMF Asian Financial Sector Assessment Programs highlight the importance of developing a sound framework for macroprudential supervision and the monitoring of systemic risks as financial institutions grow in size, complexity, and interconnectedness.

\section{CONCLUSION}

Financial sector growth in frontier and developing Asia has been rapid since the early 2000s, with credit-to-GDP ratios rising quickly in virtually all the countries under review. Most systems in the region are bank-centric and are concentrated (measured by either the number of institutions or the sectors to which they lend). Also common are state-owned commercial banks-many with relatively poor balance sheets. Links to international financial markets are limited for most, given their state of financial development. But the growth of financial intermediation and financial institutions has generally outstripped supervisory capacity in 
virtually all frontier and developing Asian economies_-including for the supervision of the nonbank financial sector in several of these economies.

Several risks arise from this rapid growth, and some echo the risk elements present in Asian emerging market economies before the financial crisis of 199799. Key challenges include a shortage of qualified staff, a lack of technical capacity, and data weaknesses that severely impair the quality of surveillance and supervision. Risk-based supervision is at an early stage of implementation in virtually all of these countries. Fragmentation, weak mandates, and lack of independence are also common supervisory challenges. Enforcement of existing prudential rules lacks teeth in some frontier and developing Asian economies-particularly notable with regard to single-borrower limits and related-party lending. Few countries in frontier and developing Asia have formal and effective crisismanagement and bank resolution frameworks, including for the provision of liquidity and solvency support. Most frontier and developing Asian economies have some components of a crisis-resolution system, but fully operational frameworks are not in place.

Policy recommendations need to be tailored to country circumstances - the rate of change and development of financial sectors in different frontier and developing Asian countries varies widely. Enhancing data collection and analysis is a critical step for virtually all the countries reviewed in this chapter because supervisory authorities cannot be effective unless they know the true condition of the institutions (including NBFIs) under their purview. Closely related is the need for supervisory resources and a steady increase in supervisory capacity to keep pace with financial sector growth and diversification. Effective prudential frameworks are another key element of successful risk management, thus it is critical that the supervisory structure be supported by independent institutions and a fully developed crisis-resolution framework. As frontier and developing Asian economies continue to develop, additional resources may also need to be devoted to macroprudential frameworks, which are more common in emerging market and middle-income countries.

Frontier and developing Asian economies have made progress in improving the key pillars of financial sector supervision since 2000. For some, the onset of financial sector difficulties (in the bank or nonbank sector) served as a catalyst for reform. For others, supervision has gained greater attention because of the perception that risks are on the rise, the need to ensure that financial intermediation can contribute to sustained economic growth, and the prospect of entry into the market by foreign financial institutions. Most frontier and developing Asian economies have financial sector reform plans, and virtually all are intensive users of IMF technical assistance in this area, as well as of assistance from the World Bank. The areas that have improved most visibly focus on the quality and timeliness of supervision, reforms to the legal framework (usually through central bank or commercial bank laws), and the bolstering of financial sector infrastructure such as deposit insurance and credit registries. 
APPENDIX 7A: ASSESSING VULNERABILITY, PREPAREDNESS, AND POLICY RESPONSE

TABLE A7.1

\begin{tabular}{|c|c|c|c|c|c|c|c|}
\hline \multicolumn{8}{|c|}{ Authorities' Responses to Financial Sector Vulnerabilities } \\
\hline & $\begin{array}{l}\text { Domestic Financial } \\
\text { Sector Reform } \\
\text { Program }\end{array}$ & $\begin{array}{c}\text { FSAP } \\
\text { Completed or } \\
\text { in Process }\end{array}$ & $\begin{array}{l}\text { Average Intensity of } \\
\text { IMF Technical } \\
\text { Assistance, 2010-13 }\end{array}$ & $\begin{array}{c}\text { Share (\%) of Financial } \\
\text { Sector TA out of Total } \\
\text { TA Hours, } 2010-13^{1} \\
\end{array}$ & $\begin{array}{l}\text { World Bank } \\
\text { Technical } \\
\text { Assistance }\end{array}$ & Areas of Progress & Areas for Further Improvement \\
\hline Bangladesh & Yes & 2003,2010 & High & 54.7 & Yes & $\begin{array}{l}\text { Bank supervision; risk and capital } \\
\text { management; stress testing; prudential } \\
\text { standards. }\end{array}$ & $\begin{array}{l}\text { Loan classification and provisioning; } \\
\text { enforcement of prudential standards; } \\
\text { nontraditional banking; credit } \\
\text { information; state banks. }\end{array}$ \\
\hline Bhutan & No & No & Low & 0.0 & No & Central bank act; regulatory regime & $\begin{array}{l}\text { Prudential standards; supervisory } \\
\text { capacity; rapid credit expansion. }\end{array}$ \\
\hline Cambodia & Yes & 2010 & High & 46.8 & Yes & $\begin{array}{l}\text { FSI compilation; asset classification and } \\
\text { provisioning; capital requirements }\end{array}$ & $\begin{array}{l}\text { Low supervisory capacity and human } \\
\text { resources; weak financial data quality; } \\
\text { concentration of assets; weak oversight } \\
\text { of foreign firms; emergence of NBFIs. }\end{array}$ \\
\hline Lao P.D.R. & No & No & Medium & 0.0 & No & State bank restructuring & $\begin{array}{l}\text { Rapid credit growth; weak risk } \\
\text { management capacity; data gaps in } \\
\text { financial reporting; quality of FSIs. }\end{array}$ \\
\hline Maldives & No & No & High & 61.7 & Yes & Deposit insurance; AML/CFT legislation & $\begin{array}{l}\text { Weak supervision; regulatory forbearance; } \\
\text { state banks }\end{array}$ \\
\hline Mongolia & Yes & 2008, 2011 & High & 10.1 & Yes & $\begin{array}{l}\text { Prudential requirements; deposit } \\
\text { insurance; credit registry. }\end{array}$ & $\begin{array}{l}\text { FSI data; forbearance, weak governance; } \\
\text { cross-ownership and asset concentration. }\end{array}$ \\
\hline Myanmar & Yes & No & High & 40.5 & Yes & $\begin{array}{l}\text { Central bank law; improved supervisory } \\
\text { and regulatory framework; NPL and } \\
\text { bank capital definition. }\end{array}$ & $\begin{array}{l}\text { Weak supervision; rapid credit growth; } \\
\text { shadow financial system. }\end{array}$ \\
\hline Nepal & Yes & 2014 & High & 22.2 & Yes & $\begin{array}{l}\text { Central bank law; supervision; prudential } \\
\text { standards; deposit insurance; financial } \\
\text { institutions legal framework; bank resolution. }\end{array}$ & $\begin{array}{l}\text { Insufficient supervisory capacity; weak FSI } \\
\text { reporting; capital adequacy; shadow } \\
\text { banking; forbearance. }\end{array}$ \\
\hline $\begin{array}{l}\text { Papua New } \\
\text { Guinea }\end{array}$ & Yes & 2011 & Low & 50.0 & Yes & $\begin{array}{l}\text { Supervision; central bank act and } \\
\text { financial institutions law. }\end{array}$ & $\begin{array}{l}\text { Prudential standards; legal framework for } \\
\text { problem bank management; insufficient } \\
\text { funding and staffing for supervision. }\end{array}$ \\
\hline Sri Lanka & Yes & $\begin{array}{l}2002,2008, \\
2013\end{array}$ & Low & 9.1 & Yes & $\begin{array}{l}\text { Supervisory capacity; state bank reform; } \\
\text { NBFI oversight }\end{array}$ & $\begin{array}{l}\text { Prudential standards; crisis management } \\
\text { framework; bank resolution framework; } \\
\text { macroprudential policy coordination. }\end{array}$ \\
\hline Timor-Leste & No & No & High & 34.2 & No & & \\
\hline Vietnam & Yes & 2013 & High & 41.9 & Yes & Capital adequacy. & $\begin{array}{l}\text { Supervision; prudential standards; FSI data; } \\
\text { resolution framework; licensing framework. }\end{array}$ \\
\hline
\end{tabular}

Sources: IMF, Monetary and Capital Markets Department and Office of Technical Assistance Management; IMF technical assistance and staff reports; and World Bank.

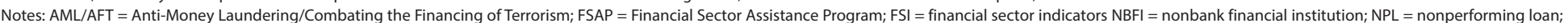

$\mathrm{TA}=$ technical assistance.

'Does not include resident advisers in Bangladesh, Cambodia, Myanmar, Nepal, and Vietnam.

CInternational Monetary Fund. Not for Redistribution 
APPENDIX 7B

TABLE A7.2

\section{Foreign Bank Entry}

\begin{tabular}{l} 
Timeline \\
\hline Country \\
\hline Korea \\
Branches of foreign banks allowed since end-1967, although not allowed \\
to engage in retail banking. \\
1992—Foreign security companies authorized to do business. Only \\
branches allowed. \\
1993-Announcement of a five-year plan aimed mainly at interest rate \\
deregulation and abolishing the limits on maximum maturity loans and \\
deposits. \\
1996-Korean government announcement of a blueprint to remove \\
barriers from foreign portfolio investment and foreign direct investment. \\
1998-Foreign banks and securities firms from Organisation for Economic \\
Co-operation and Development (OECD) countries allowed to establish \\
subsidiaries in Korea. \\
2000-Aggregate foreign investment ceilings for investors from OECD \\
countries to be phased out. \\
Ceilings on foreign equity ownership increased from 49 percent in 1996-97 to \\
100 percent (no limits) after the financial crisis of 2007-08. \\
If foreign equity participation in domestic banks exceeds 10, 25, and \\
33 percent up to 100 percent, it needs to be approved by the Financial \\
Supervisory Committee. \\
Before 1997, foreign commercial banks were limited to a single branch with \\
no automated teller machines and focused primarily on trade financing, \\
with little emphasis on retail banking. Foreign banks could operate in a more \\
limited capacity under an offshore license as an international banking \\
facility. Following the 1997-98 financial crisis, up to 100 percent foreign \\
ownership of domestic financial institutions on a case-by-case basis for a \\
10-year period was allowed, after which the foreign banks would not be able \\
to take up additional equity unless they held less than 49 percent of equity. \\
2004-Foreign banks allowed to open branches or subsidiaries.
\end{tabular}

Ownership in local banks, then fully owned branches and subsidiaries. However, fully owned branches and subsidiaries restricted in the number of offices allowed.

A foreign bank subsidiary allowed to open one branch within Bangkok and three branches

elsewhere. A full branch of a foreign bank cannot open any branches.
Level of Financial Liberalization when Entry Is Allowed'

Relatively low when branches were allowed in 1967, with

substantial interest rate

controls.

Exchange restrictions present.

Relatively high during period

when subsidiaries were

allowed.

Article VIII-November 1988.

Relatively high. Some interest controls (deposit ceilings present).

No exchange restrictions during

1997 liberalization.

Article VIII-May 1990.

\section{CInternational Monetary Fund. Not for Redistribution}



(JVs) allowed in 1988.

Before 1998, foreign ownership in local banks was limited to 49 percent. 1998-Foreigners allowed to directly acquire or purchase bank shares through stock exchange and own up to 99 percent of listed and private banks and JVs.

Malaysia

Full foreign bank presence allowed for many years in the form of subsidiaries. Ownership of local institutions limited to 30 percent. In 2011, limit on foreign ownership of local Islamic banks raised to

70 percent.

China

During 1980s and 1990s, operations of foreign banks restricted mostly to special economic zones. The timeline was, to a large extent, influenced by commitments under the entry to the World Trade Organization (WTO) in 2001.

2003-Foreign ownership limit in local banks raised to 25 percent from 15 percent.

2007-Foreign banks allowed to establish branches, subsidiaries, and JVs after establishing a representative office. Limits on foreign ownership of 20 percent for individual investors and 25 percent overall.

In the early 1990s, foreign banks allowed to acquire stakes in local banks, initially at 10 percent, growing to 47 percent by 1996 and 75 percent after 2007.

2005-new-entrant foreign banks allowed to open 100 percent owned

subsidiaries or branches outright and the limit on the number of branch offices abolished.
Bank branches first, subsidiaries and JVs later.

Similar regulations for subsidiaries and branches.

Big push for liberalization (implemented during the Asian crisis).

Limited foreign subsidiary and foreign ownership allowed in local banks. No branches allowed.

Only foreign commercial banks with a representative office in China for at least two years before the application, and with total assets of at least $\$ 10$ billion at the end of the year preceding the application allowed to apply for establishment of a wholly foreign-funded subsidiary, with higher restrictions for branches. Banks that do not incorporate locally must take individual deposits of at least 1 million renminbi, which limits their ability to compete.

Allowed investment in foreign banks first, subsidiaries and branches later.
Relatively low when bank branches were allowed in 1967.

Interest controls present.

Relatively high during "big bang" episode of 1998

Exchange restrictions in place when bank branches were allowed. No exchange restrictions during big bang of 1998.

Article VIII-May 1988.

Relatively high. Some interest controls in place when bank presence was allowed.

No exchange restrictions. Article VIII-November 1968

Limited, with interest rate controls.

No exchange restrictions during post-WTO reforms.

Article VIII—December 1996.

Significant financial liberalization measures undertaken simultaneously with allowing bank entry, including liberalization of interest rate. No exchange restrictions. Article VIII-August 1994.

\section{(CInternational Monetary Fund. Not for Redistribution}




\section{Foreign Bank Entry}

\begin{tabular}{|c|c|c|c|}
\hline Country & Timeline & Model & $\begin{array}{l}\text { Level of Financial Liberalization } \\
\text { when Entry Is Allowed }\end{array}$ \\
\hline & \multicolumn{3}{|c|}{ Asian Emerging Market Economies } \\
\hline Singapore & $\begin{array}{l}\text { 1999-Five-year liberalization program allowed qualified foreign banks to } \\
\text { conduct operations with residents on a broad scale. } \\
2012 \text { - announcement that some qualifying full banks deeply rooted in } \\
\text { the economy would be required to incorporate locally. }\end{array}$ & $\begin{array}{l}\text { Foreign banks operating with Singapore residents } \\
\text { need to acquire special license. } \\
\text { Branches are required to maintain minimum level } \\
\text { of assets in proportion to their liabilities. Limits on } \\
\text { foreign equity ownership in foreign banks ( } 40 \\
\text { percent). }\end{array}$ & $\begin{array}{l}\text { High. } \\
\text { No interest controls. } \\
\text { No exchange restrictions. } \\
\text { Article VIII-November } 1968 .\end{array}$ \\
\hline
\end{tabular}

Bangladesh After nationalization of the banking system in 1972, foreign banks allowed to operate as branches. Nine foreign commercial banks are operating in Bangladesh as branches of banks that are incorporated abroad.

Bhutan

The Bank of Bhutan established in 1968 as a JV with Chartered Bank of India, Australia, and China. In 1973 it was reconstituted as a JV with the State Bank of India (SBI), which held a 40 percent stake. SBI's share was reduced to 20 percent in 1987. Druk PNB entered the market as a JV with Punjab National Bank holding more than 51 percent.

Cambodia In the early 1990s, private banks allowed during the transition away from the monobank model. Domestic and foreign banks treated equally and required to start as JVs with the National Bank of Cambodia (NBC). The reform initially created four commercial banks (two domestic, two

foreign). Within two years, the government eliminated the JV requirement with NBC. All commercial banks-domestic and foreign—could start with 100 percent private equity. Thus, beginning in 1993, 100 percent foreign ownership allowed. Unlike in neighbors (such as Vietnam), foreign banks allowed to mobilize domestic deposits from the beginning. No special approval needed for foreign banks to open new branches (but some capital requirements for domestic banks and new branches).
Foreign banks in Bangladesh are exclusively branches and are broadly subject to similar prudential requirements, although the licensing process for opening new branches is less stringent for foreign commercial banks than for Bangladeshi banks.

Branches, subsidiaries, and JVs allowed by law. Joint venture foreign ownership limited to 51 percent.

Big-bang approach. The banking system was liberalized to include both domestic and foreign investors with comparable treatment. No difference in regulatory treatment between branches and subsidiaries.
Low.

w. Financial liberalization increasing since 2010 as a result of reforms.

Mostly liberalized (big-bang approach), including with regard to interest rates. Exchange restrictions present. Article VIII-January 2002

\section{CInternational Monetary Fund. Not for Redistribution}


Maldives Four branches of foreign banks opened since mid-1970s:

- State Bank of India, Malé branch established in 1974

- Habib Bank Limited, Malé branch established in 1976

- Bank of Ceylon, Malé branch established in 1981

- HSBC, Malé branch established in 2002

One subsidiary of a foreign bank: Mauritius Commercial Bank, Maldives, established in 2008.
Foreign participation in the banking sector currently limited to "representative offices" of Standard Chartered, ING, and Bank of China. In 2012, new bank regulation allowed establishment of subsidiaries. Foreign banks may establish local subsidiaries no earlier than one year after establishment of their Mongolian representative offices. Initial capital requirements for foreign subsidiaries significantly higher than for domestic banks.

participation. Bank may open after establishment
JV banks and foreign bank branches allowed simultaneously. No subsidiaries allowed.

No upper limit on foreign equity in $\mathrm{JV}$, lower limit of at least 30 percent.

Legally, no restrictions on foreign ownership, but the authorities exercise discretion. The Maldives Monetary Authority (MMA) encourages and welcomes foreign entrants to the Maldivian banking and financial industry and considers proposals from foreign and local applicants. MMA encourages increased participation by local investors because of the benefits of retention of profits and attentiveness to the needs of the local economy; however, paramount importance placed on the overall quality and competence of the proposed owners, board of directors, and executive management. MMA indicates that it makes no distinction between nor has a preference for whether a foreign bank applies to establish a presence in Maldives as a branch or subsidiary. Foreign banks may apply for license to operate in either capacity. Critical factors for MMA are whether there are any constraints or requirements posed by the group or organizational structure of the applicant or the applicant's home country regulator and whether operations in Maldives will help or hinder MMA's ability to properly supervise and regulate the new entrant.

Low.

Exchange restrictions present. Article VIII-May 2010.

\section{Low.}

No explicit restrictions in the law on operating

branches, subsidiaries, or banks with joint

Current level relatively high.

of representative offices. 
TABLE A7.2 (Continued)

\section{Foreign Bank Entry}

\begin{tabular}{|c|c|c|c|}
\hline Country & Timeline & Model & $\begin{array}{l}\text { Level of Financial Liberalization } \\
\text { when Entry Is Allowed }\end{array}$ \\
\hline & \multicolumn{3}{|c|}{ Frontier and Developing Asia } \\
\hline Myanmar & No foreign bank presence yet. & $\begin{array}{l}\text { Not decided. Authorities considering allowing JVs } \\
\text { first. }\end{array}$ & $\begin{array}{l}\text { No foreign bank entry allowed } \\
\text { yet. Banking system subject to } \\
\text { various restrictive controls. }\end{array}$ \\
\hline Nepal & $\begin{array}{l}\text { First foreign JV bank set up as Nepal Arab Bank Ltd (now Nabil Bank Ltd) in } \\
\text { 1984. Two foreign JV banks, Nepal Indosuez Bank Ltd (now Nepal } \\
\text { Investment Bank) and Nepal Grindlays Bank Ltd (now Standard Chartered } \\
\text { Bank Nepal Ltd) established in } 1986 \text { and 1987, respectively. Currently } 17 \\
\text { commercial banks in operation: } 6 \text { foreign JVs and } 11 \text { fully domestic banks. }\end{array}$ & JVs. & Relatively high. \\
\hline $\begin{array}{l}\text { Papua New } \\
\text { Guinea }\end{array}$ & $\begin{array}{l}\text { Branches of ANZ and the National Bank of Australia opened in the 1950s. } \\
\text { In the 1970s, foreign branches converted into subsidiaries. In 1983, Papua } \\
\text { New Guinea invited the banks to open affiliates (JVs) on the condition } \\
\text { that the foreign parent could own only } 49 \text { percent and the central bank } \\
\text { would buy the portion of the remaining shares that foreign investors did } \\
\text { not pick up. Today, out of four major banks, three are foreign owned: } \\
\text { ANZ, Westpac, and Maybank. }\end{array}$ & $\begin{array}{l}\text { No official limits; currently all foreign banks operate } \\
\text { as subsidiaries. }\end{array}$ & Relatively low. \\
\hline Sri Lanka & $\begin{array}{l}\text { Branches of foreign banks allowed in } 1979 . \\
\text { Limits on foreign ownership by foreign banks raised to } 90 \text { percent from } 60 \\
\text { percent in } 2000 .\end{array}$ & $\begin{array}{l}\text { No restrictions on foreign shareholdings or } \\
\text { opening branches and subsidiaries. However, } \\
\text { there are restrictions on the number of expatriates } \\
\text { employed by foreign banks: } \\
\text { - } 3 \text { for banks with fewer than } 75 \text { staff } \\
\text { - } 5 \text { for banks with staff of } 75 \text { to } 400 \\
\text { - } 10 \text { for banks with more than } 400 \text { staff } \\
\text { Employment of expats by local banks on a case-by- } \\
\text { case basis. } \\
\text { Discretionary considerations for opening of } \\
\text { branches of foreign banks. }\end{array}$ & Relatively low. \\
\hline
\end{tabular}

\section{CInternational Monetary Fund. Not for Redistribution}


Vietnam

1990-Representative offices of commercial banks allowed.

1994-Foreign banks allowed to take minority stakes in local banks as JVs.

2008-100 percent foreign owned foreign bank subsidiaries allowed.

Limits on foreign equity ownership in foreign banks of 30 percent.
Foreign banks initially could enter Vietnam through purchase of minority stakes in local banks. Foreign ownership share of JV banks limited to 49 percent of capital. At least 20 percent of managers, executives, and specialists must be foreign nationals in the JV bank. Onshore foreign bank branches initially not allowed to open entry points ther than their head offices. Fully owned

subsidiaries allowed later. Additional restrictions

on branches to open local offices.

Sources: Country documents and research papers; and IMF country teams.

${ }^{1}$ Notations for Article VIII indicate when the member country accepted the obligations of Article VII under the IMF's Articles of Agreement. Obligations of members under Article VIII include avoidance of restriction on the making of payments and transfers for current international transactions, avoidance of discriminatory currency practices (including multiple currency practices) and providing necessary information to the IMF.

Relatively low. Various

restrictions, including interest

rate ceilings.

Exchange restrictions present.

Interest rate ceilings reimposed in 2008.

Article VIII—November 2005 


\section{APPENDIX 7C: CONDITIONS FOR FOREIGN BANK ENTRY}

Regardless of the model of bank entry used, a number of regulatory and supervisory conditions need to be in place to ensure that foreign bank entry is consistent with financial sector stability:

- Criteria for foreign bank entry: The foreign bank should be a reputable financial institution from a country with a strong regulatory and supervisory regime. The applications should not discriminate by region or domicile of the bank.

- Necessary supervisory and regulatory elements: A strong regulatory and supervisory framework is essential for maintaining financial stability during any liberalization of the financial system, regardless of foreign entry. However, the minimum regulatory and supervisory elements that should ideally be in place include the following:

- Establishing contact and coordination with home-country supervisors of foreign banks that are applying to enter the market: Coordination should follow best principles outlined by the Basel Committee. ${ }^{4}$ Regular and well-defined relations and information sharing between home and host country supervisors are essential for effective consolidated bank supervision of foreign branches and subsidiaries.

- Enhancing bank governance to ensure arm's-length relations between bank management and bank customers, including through strengthened connected-lending limits and fit-and-proper requirements.

- Establishing a level playing field between state and private banks by subjecting the former to the same regulations and supervision: Identical regulation is especially relevant for countries in which certain banking activities (for example, international banking and sectoral lending) are subject to some degree of government control and state banks are not subject to the same requirements as private banks.

The regulations should accommodate cross-border financial flows and dividend payments essential for foreign investment and financial operations. At a minimum, clear guidelines on dividend policy, repatriation of profits, and transfer of foreign shares to third parties should be established. For example, there may be a need to liberalize borrowing from abroad (for branches, predominantly from the parent; for subsidiaries, this may include the broader market, at par with domestic banks) and payment of interest on such borrowing, extension of financial credits from residents to nonresidents (for domestic bond issuance, for instance), and other related restrictions.

\footnotetext{
${ }^{4}$ The Basel Committee on Banking Supervision advises that all international banking groups and international banks be supervised by a home country authority that capably performs consolidated supervision. The creation of a cross-border banking establishment should receive the consent of both the host supervisor and the bank's supervisor, and if different, the banking group's home country supervisor. Supervisors should possess the right to gather information from cross-border banking establishments of the banks or banking groups for which they are the home country supervisors. If a host country supervisor determines that any one of these minimum standards is not met to its satisfaction, it could impose restrictive measures or prohibit the establishment of banking offices.
} 


\section{REFERENCES}

Alessi, Lucia, and Carsten Detken. 2009. “'Real Time’ Early Warning Indicators for Costly Asset Price Boom/Bust Cycles: A Role for Global Liquidity." ECB Working Paper 1039, European Central Bank, Frankfurt.

Bank for International Settlements (BIS). 2013. Consolidated Banking Statistics online information. Basel.

Barth, James R., Gerard Caprio, and Ross Levine. 2004. "Bank Regulation and Supervision: What Works Best?" Journal of Financial Intermediation 13 (2): 205-48.

Borio, Claudio, and Mathias Drehmann. 2009. "Assessing the Risk of Banking CrisesRevisited.” BIS Quarterly Review March: 29-46.

Borio, Claudio, and Philip Lowe. 2002. "Asset Prices, Financial and Monetary Stability: Exploring the Nexus." BIS Working Paper 114, Bank for International Settlements, Basel.

. 2004. "Securing Sustainable Price Stability: Should Credit Come Back from the Wilderness?" BIS Working Paper 157, Bank for International Settlements, Basel.

Caprio, Gerard, Jonathan L. Fiechter, Robert E. Litan, and Michael Pomerleano, eds. 2004. The Future of State-Owned Financial Institutions. Washington: Brookings Institution.

Corsetti, Giancarlo, Paulo Presenti, and Nouriel Roubini. 1998. "What Caused the Asian Currency and Financial Crisis?” NBER Working Paper 6833, National Bureau of Economic Research, Cambridge, Massachusetts.

Gerdesmeier, Dieter, Hans-Eggert Reimers, and Barbara Roffia. 2009. "Asset Price Misalignments and the Role of Money and Credit." ECB Working Paper 1068, European Central Bank, Frankfurt.

Gupta, Poonam, Kalpana Kochhar, and Sanjaya Panth. 2011. "Bank Ownership and the Effects of Financial Liberalization: Evidence from India." IMF Working Paper 11/50, International Monetary Fund, Washington.

International Monetary Fund (IMF). 2011a. "Mongolia: Financial System Stability Assessment." IMF Country Report 11/107, Washington.

. 2011b. "Papua New Guinea: Financial System Stability Assessment." IMF Country Report 11/163, Washington.

- 2011c. "Toward Operationalizing Macroprudental Policies: When to Act." In Global Financial Stability Report, September, Washington.

. 2011d. "Subsidiaries or Branches: Does One Size Fit All?" IMF Staff Discussion Note 11/04, Washington.

—. 2013. World Economic Outlook database, Washington. http://www.imf.org/external /pubs/ft/weo/2013/01/weodata/index.aspx.

Körner, Tobias, and Isabel Schnabel. 2010. "Public Ownership of Banks and Economic Growth-The Role of Heterogeneity." Discussion Paper 8138, Max Planck Institute for Research, Bonn.

La Porta, Rafael, Florencio Lopez-de-Silanes, and Andrei Shleifer. 2002. "Government Ownership of Banks." Journal of Finance 57 (1): 265-301.

Levy-Yeyati, E., A. Micco, and Ugo Panizza. 2007. "A Reappraisal of State-Owned Banks," Economía 7 (2): 209-47.

Mishra, P., P. J. Montiel, and A. Spilimbergo, 2010. "Monetary Transmission in Low Income Countries." IMF Working Paper 10/223, International Monetary Fund, Washington.

Ostry, Jonathan D. 1999. "The Asia Crisis: Causes, Policy Responses, and Outcomes." IMF Working Paper 99/138, International Monetary Fund, Washington.

Ree, Jack Roo. 2011. "Impact of the Global Crisis on Banking Sector Soundness in Asian LowIncome Countries." IMF Working Paper 11/115, International Monetary Fund, Washington.

Rose, Andrew K., and Mark M. Spiegel. 2009. "Cross-Country Causes and Consequences of the 2008 Crisis: Early Warning." Federal Reserve Bank of San Francisco Working Paper 2009-17. 2013a. Financial Sector Data database. http://data.worldbank.org/topic/financial-sector? display=default.

World Bank. 2013b. Economic Policy and External Debt Data. Washington. http://worldbank .org/topic/economic-policy-and-external-debt.

\section{CInternational Monetary Fund. Not for Redistribution}


This page intentionally left blank

CInternational Monetary Fund. Not for Redistribution 


\section{Frontier Markets in Asia and Beyond}

\section{Nehad Chowdhury, Martin Edmonds, AND Chris Walker}

As growth in several major emerging market economies has slowed, economists and investors alike have shown more interest in a second group of countries in Asia and beyond-the frontier economies. A number of these economies have already accessed global capital markets, as noted in Chapter 1. A flurry of international bond issuances by some, and outsized gains in the equity markets of others, have boosted the prospects of frontier markets as an attractive investment destination. As a result, the question arises whether frontier markets will be in a position to capitalize on their recent successes and eventually graduate to emerging market status. Along the same lines, what are the lessons from today's frontier markets for other fast-growing low-income countries, especially in Asia, as they try to become frontier markets?

With their strong growth prospects, relative underdevelopment, young and growing populations, and nascent financial markets, frontier economies present compelling investment opportunities (Figure 8.1). Strong returns in bond and equity markets, underpinned by domestic fundamentals and unusual external conditions, have resulted in increased investment portfolio allocations in frontier assets. A large number of lower-income countries, especially in Asia and Africa, have experienced prolonged growth spurts and significantly improved fundamentals, lending credibility to their claim to be considered frontier economies. As a group, frontier Asia has experienced growth over the past two decades averaging 6 percent, which only China and India have surpassed. Frontier economies have benefited from a supportive global environment of relatively low interest rates and high commodity prices. Many of these fast-growing low-income countries have been able to tap global capital markets and have also attracted investments from nonresidents in their domestic bond and equity markets. Even less-developed countries may join the club of frontier economies in the not-too-distant future. ${ }^{1}$

This chapter explores the conditions under which such lower-income countries could advance to frontier or emerging market status. In many cases, this

\footnotetext{
${ }^{1}$ In the case of Asia, the investment community lacks consensus on which countries might join, but the frontier market cohort generally includes Pakistan, Sri Lanka, and Vietnam and sometimes Bangladesh and Mongolia. The next wave of frontier economies includes a group of smallish countries with financial markets at the early stages of development: Bhutan, Brunei Darussalam, Cambodia, Lao P.D.R., Maldives, Myanmar, Nepal, Papua New Guinea, and Timor-Leste.
} 


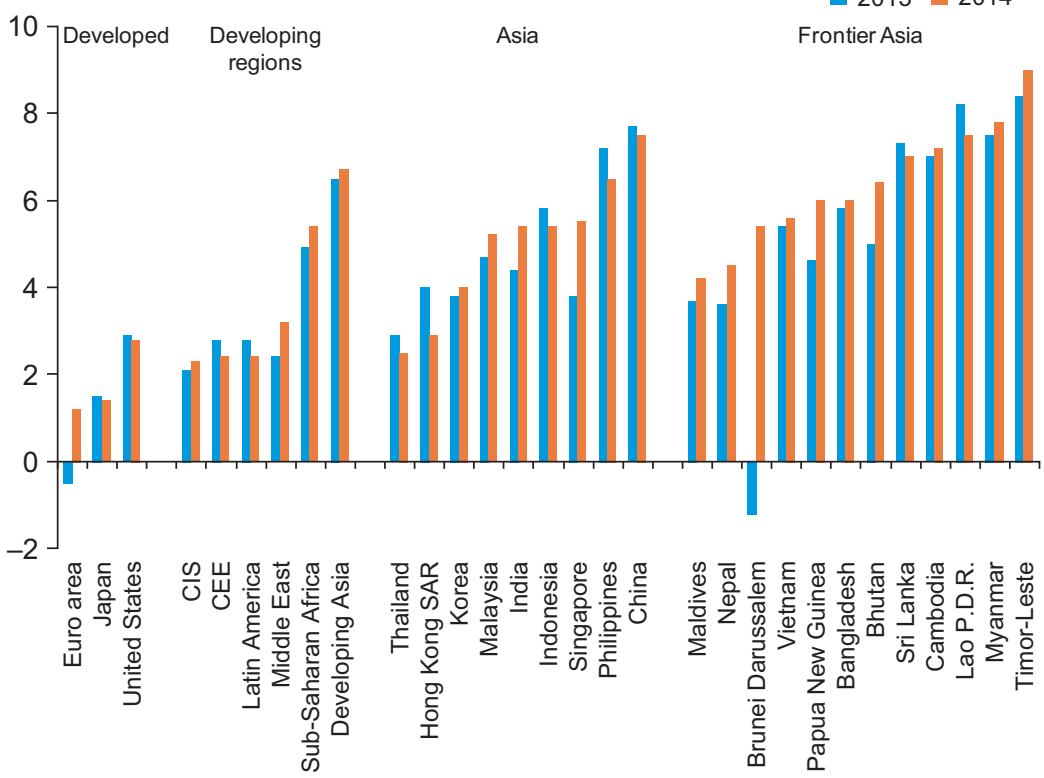

Figure 8.1 Real GDP Growth (Percent year-over-year)

Sources: IMF, World Economic Outlook database.

Note: $\mathrm{CEE}=$ Central and Eastern Europe; $\mathrm{CIS}=$ Commonwealth of Independent States.

reflects not only the impact of improved fundamentals, but also the global liquidity environment. The analysis considers frontier economies from the capital market side, including both bond and equity markets. In the case of the former, it examines the ability of frontier economies to issue sovereign bonds (that is, external bonds), as well as the role of nonresident investments in local bond markets. The chapter also identifies the main elements that distinguish emerging markets from the more underdeveloped frontier markets and determines what is needed for frontier markets to become emerging markets.

\section{WHAT ARE FRONTIER MARKETS?}

There is no uniform definition of frontier markets, but rather a common understanding that they do not fulfill the generalized criteria for full-fledged emerging markets. Following the advent of the concept of emerging markets in the early 1980s, Farida Khambata of the International Finance Corporation introduced the notion of frontier markets in the following decade. Generally speaking, frontier markets are smaller, less liquid, and less investable than their more established emerging market peers. Although "emerging market" has become a mainstream term, "frontier market" is still largely confined to the international investment community. 
TABLE 8.1

\begin{tabular}{|c|c|c|c|}
\hline \multicolumn{4}{|c|}{ Supranational Country Classifications } \\
\hline & IMF & UNDP & World Bank \\
\hline $\begin{array}{l}\text { Name of "developed } \\
\text { countries" }\end{array}$ & Advanced countries & Developed countries & High-income countries \\
\hline $\begin{array}{l}\text { Name of "developing } \\
\text { countries" }\end{array}$ & $\begin{array}{l}\text { Emerging and } \\
\text { developing countries }\end{array}$ & Developing countries & $\begin{array}{l}\text { Low- and middle- } \\
\text { income countries }\end{array}$ \\
\hline $\begin{array}{l}\text { Development } \\
\text { threshold }\end{array}$ & Not explicit & $\begin{array}{l}75 \text { percent in the } \\
\text { Human Development } \\
\text { Index distribution }\end{array}$ & $\begin{array}{l}\text { US\$6,000 GNI/capita in } \\
1987 \text { prices }\end{array}$ \\
\hline $\begin{array}{l}\text { Type of development } \\
\text { threshold }\end{array}$ & Most likely absolute & Relative & Absolute \\
\hline $\begin{array}{l}\text { Subcategories of } \\
\text { "developing } \\
\text { countries" }\end{array}$ & $\begin{array}{l}\text { (1) Low-income } \\
\text { developing countries; } \\
\text { and (2) Emerging and } \\
\text { other developing } \\
\text { countries }\end{array}$ & $\begin{array}{l}\text { (1) Low human develop- } \\
\text { ment countries; } \\
\text { (2) Medium human } \\
\text { development coun- } \\
\text { tries; and (3) High } \\
\text { human development } \\
\text { countries }\end{array}$ & $\begin{array}{l}\text { (1) Low-income coun- } \\
\text { tries; and ( } 2 \text { ) Middle- } \\
\text { income countries }\end{array}$ \\
\hline
\end{tabular}

Sources: Nielsen (2011); and IMF staff.

Notes: GNI = gross national income; UNDP = United Nations Development Programme.

Frontier markets are occasionally grouped with other developing economies to differentiate them from developed economies, and they are considered a subset of the emerging market universe. More correctly, frontier markets should be viewed as a "preemerging market" class of markets. Apart from the International Finance Corporation, the international development community has not embraced the term. Frontier economies generally fall into subcategory (1) in Table 8.1's classification in the subcategories of developing economies, but such groupings also include many countries that have no financial markets. Accordingly, this sweeping categorization does not accurately reflect the circumstances of frontier economies. Instead, families of bond and equity market indices as developed by the international investment community effectively remain the prime determinants of frontier market status.

\section{The Frontier Bond Market Universe}

To bond investors, frontier markets are most readily characterized by their credit ratings. As a general rule, sovereign ratings in such markets are below investment grade $(\mathrm{BB}+$ or below on the Standard \& Poor's scale), although there are exceptions. Such ratings, in turn, reflect a number of conditions, including the sovereign's issuance and debt service history, debt levels, macroeconomic and policy fundamentals, and political conditions that may affect either the willingness or ability to repay creditors. Many frontier markets have accessed global capital markets recently, and many have increasingly allowed investments by nonresidents in local bond markets.

Frontier market designations are largely the domain of index families established by the international investment community. Several major banks produce 
indices of emerging and frontier markets, including Bank of America Merrill Lynch, Barclays, Citigroup, and HSBC_-but J.P. Morgan's are the most popular benchmarks (Table 8.2; Kim 2014). Three such indices are the

- EMBI (Emerging Markets Bond Index): The original EMBI index consisted of Brady bonds and as such was dominated by Latin American names. The ensuing EMBI+ added dollar-denominated loans and Eurobonds. The EMBI Global was added in 1999 with a far larger country set and further expanded coverage to quasisovereigns. By 2014, the EMBI Global had more than 50 countries represented. A variant, the EMBI Global Diversified index (which restricts constituent country weights to a maximum of 10 percent) is the mostly widely used benchmark for U.S. sovereign investors. There is further a U.S. dollar corporate equivalent (Corporate Emerging Markets Bond Index) as well as a Euro EMBI Global index.

- NEXGEM (Next Generation Emerging Market): NEXGEM is a dollar index and is effectively a frontier market subset of the EMBI Global index. More than 80 percent of the index is rated single-B or lower. Asia accounts for 27 percent of the index (Figure 8.2). The external debt of Sri Lanka and Vietnam are in both the EMBI Global and NEXGEM indices. If Bangladesh were to issue a U.S. dollar-denominated bond of benchmark size it would very likely be included in these indices.

- GBI (Government Bond Index): This index was launched in 1989 as a benchmark for global investors in developed government bond markets. The GBI Global comprises 13 countries with noticeable market depth and liquidity (Figure 8.3). The GBI Broad launched in 1997 expanded coverage as a response to investors looking for higher yields. The GBI-EM series was launched in 2005 to track performance in local emerging markets and has a fairly narrow focus. The GBI-EM Broad includes markets that may have impediments to investors, while the GBI-EM Global falls somewhere in between. The GBI-EM and GBI-EM Global both exclude China and India. The GBI-EM Global Diversified index is the most popular with investors.

No index exists for local currency sovereign bonds in frontier markets, reflecting the infancy of these markets. It is reasonable to think of the local currency bond market of each NEXGEM member as a frontier market in the context of local currency bonds. There are also countries whose dollar bonds are not seen as frontier markets and are not members of the NEXGEM index (such as Ukraine and Serbia) because they are too developed, but whose local currency debt would be considered a frontier market by investors. In Asia, the local bond markets in Indonesia, Malaysia, and the Philippines are part of the EMBI and GBI-EM index families.

\section{The Frontier Equity Market Universe}

The International Finance Corporation created the first frontier markets equity index, and later sold it (along with the attendant database including both frontier 


\begin{tabular}{|c|c|c|c|c|c|c|c|}
\hline \multicolumn{8}{|c|}{ Emerging and Frontier Bond Market Indices, End-2013 } \\
\hline & EMBI Global & GBI-EM & NEXGEM & & EMBI Global & GBI-EM & NEXGEM \\
\hline Armenia & $\checkmark$ & & $\checkmark$ & Lebanon & $\checkmark$ & & \\
\hline Angola & $\checkmark$ & & $\checkmark$ & Lithuania & $\checkmark$ & & \\
\hline Argentina & $\checkmark$ & $\checkmark$ & $\checkmark$ & Malaysia & $\checkmark$ & $\checkmark$ & \\
\hline Azerbaijan & $\checkmark$ & & & Mexico & $\checkmark$ & $\checkmark$ & \\
\hline Belarus & $\checkmark$ & & $\checkmark$ & Mongolia & $\checkmark$ & & $\checkmark$ \\
\hline Belize & $\checkmark$ & & & Morocco & $\checkmark$ & & \\
\hline Bolivia & $\checkmark$ & & $\checkmark$ & Mozambique & & & $\checkmark$ \\
\hline Brazil & $\checkmark$ & $\checkmark$ & & Namibia & $\checkmark$ & & \\
\hline Bulgaria & $\checkmark$ & & & Nigeria & $\checkmark$ & $\checkmark$ & $\checkmark$ \\
\hline Chile & $\checkmark$ & $\checkmark$ & & Pakistan & $\checkmark$ & & $\checkmark$ \\
\hline China & $\checkmark$ & $\checkmark$ & & Panama & $\checkmark$ & & \\
\hline Colombia & $\checkmark$ & $\checkmark$ & & Paraguay & $\checkmark$ & & $\checkmark$ \\
\hline Costa Rica & $\checkmark$ & & & Peru & $\checkmark$ & $\checkmark$ & \\
\hline Côte d'Ivoire & $\checkmark$ & & $\checkmark$ & Philippines & $\checkmark$ & $\checkmark$ & \\
\hline Croatia & $\checkmark$ & & & Poland & $\checkmark$ & $\checkmark$ & \\
\hline Dominican Republic & $\checkmark$ & & $\checkmark$ & Romania & $\checkmark$ & $\checkmark$ & \\
\hline Ecuador & $\checkmark$ & & $\checkmark$ & Russia & $\checkmark$ & $\checkmark$ & \\
\hline Egypt & $\checkmark$ & $\checkmark$ & $\checkmark$ & Senegal & $\checkmark$ & & $\checkmark$ \\
\hline El Salvador & $\checkmark$ & & $\checkmark$ & Serbia & $\checkmark$ & & \\
\hline Gabon & $\checkmark$ & & $\checkmark$ & Slovakia & $\checkmark$ & & \\
\hline Georgia & $\checkmark$ & & $\checkmark$ & South Africa & $\checkmark$ & $\checkmark$ & \\
\hline Ghana & $\checkmark$ & & $\checkmark$ & Sri Lanka & $\checkmark$ & & $\checkmark$ \\
\hline Guatemala & $\checkmark$ & & $\checkmark$ & Tanzania & $\checkmark$ & & $\checkmark$ \\
\hline Honduras & $\checkmark$ & & $\checkmark$ & Thailand & & $\checkmark$ & \\
\hline Hungary & $\checkmark$ & $\checkmark$ & & Trinidad and Tobago & $\checkmark$ & & \\
\hline India & $\checkmark$ & $\checkmark$ & & Turkey & $\checkmark$ & $\checkmark$ & \\
\hline Indonesia & $\checkmark$ & $\checkmark$ & & Ukraine & $\checkmark$ & & \\
\hline Iraq & $\checkmark$ & & $\checkmark$ & Uruguay & $\checkmark$ & & \\
\hline Jamaica & $\checkmark$ & & $\checkmark$ & Venezuela & $\checkmark$ & & \\
\hline Jordan & $\checkmark$ & & $\checkmark$ & Vietnam & $\checkmark$ & & $\checkmark$ \\
\hline Kazakhstan & $\checkmark$ & & & Zambia & $\checkmark$ & & $\checkmark$ \\
\hline Latvia & $\checkmark$ & & & & & & \\
\hline
\end{tabular}

Source: J.P. Morgan.

Note: $\mathrm{EMBI}=$ Emerging Markets Bond Index; GBI-EM = Government Bond Index-Emerging Markets; NEXGEM = Next Generation Emerging Markets Index.

and emerging market components) to Standard \& Poor's, which recast it under its standard. There are currently four widely accepted frontier market index families: FTSE, Morgan Stanley Capital International (MSCI), Russell, and Standard \& Poor's (Table 8.3). MSCI is a leading benchmark, largely because its frontier markets index dovetails with its developed and emerging market indices. MSCI indices provide useful performance benchmarks for global equity market managers given their standard methodologies concerning constituents and valuations. ${ }^{2}$ Inclusion in a global market index is considered something of a milestone

\footnotetext{
${ }^{2}$ For this exercise, MSCI constituents are used for most data and analyses for equity frontier markets as well as for comparator indices for emerging and developed markets. This is convenient since MSCI is widely accepted as the global equity benchmark standard, employing a standard methodology across its equity universe.
} 


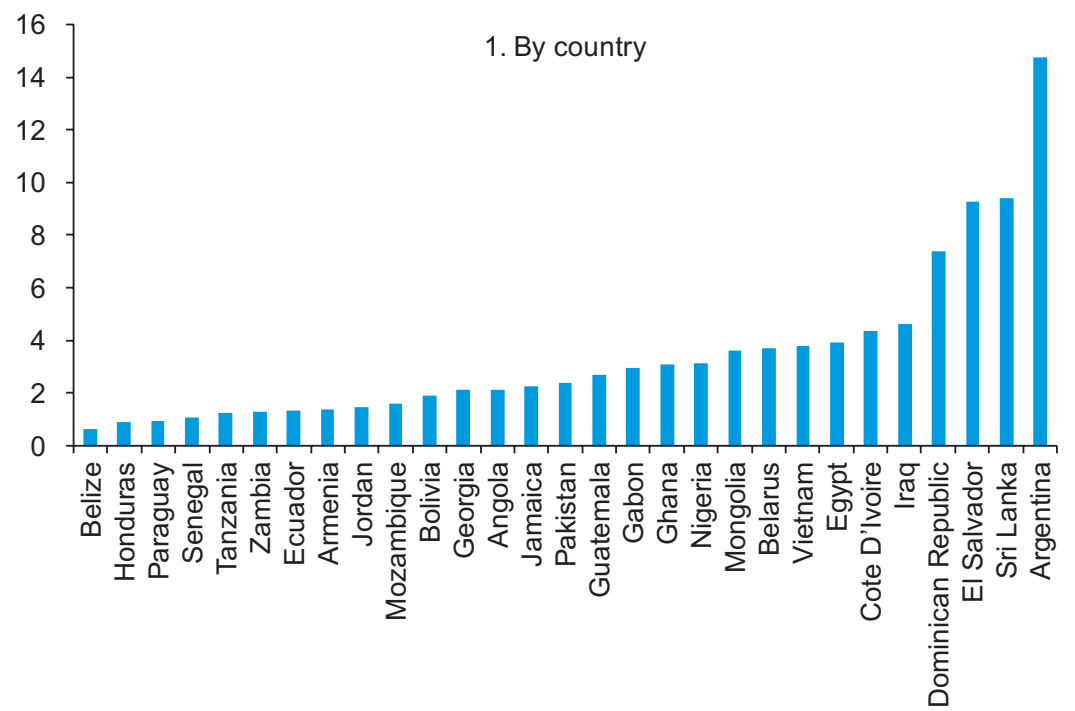

2. By region

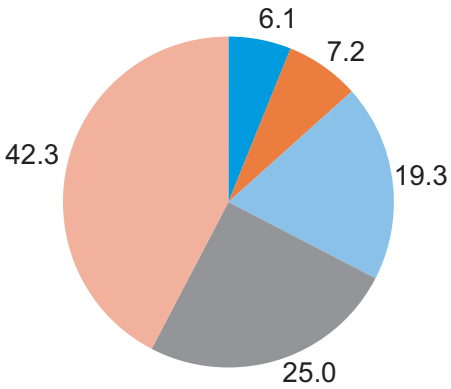

- Middle East $\square$ Africa

Europe

- Asia
3. By rating

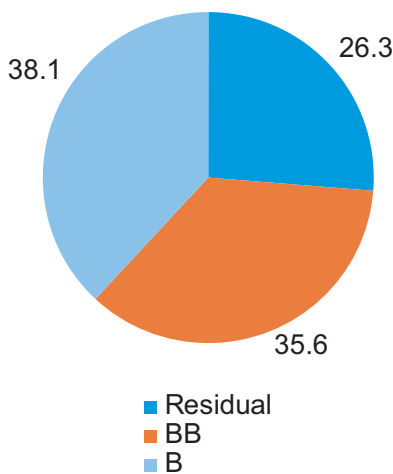

Figure 8.2 Next Generation Emerging Markets Index Composition (Percent) Source: Kim (2014)

for national equity markets, as it gives them greater international exposure and targets their inclusion in index funds.

As with emerging markets, there is no standard metric to determine the constituents of frontier market indices, with each major firm establishing its own criteria. Financials are very prevalent in frontier markets (Figure 8.4), but commodity exposure is noticeably lacking due to the prevalence of international firms and sovereign restrictions. The four major firms tracking frontier markets share about 20 sovereign names, but beyond that the composition varies considerably. 


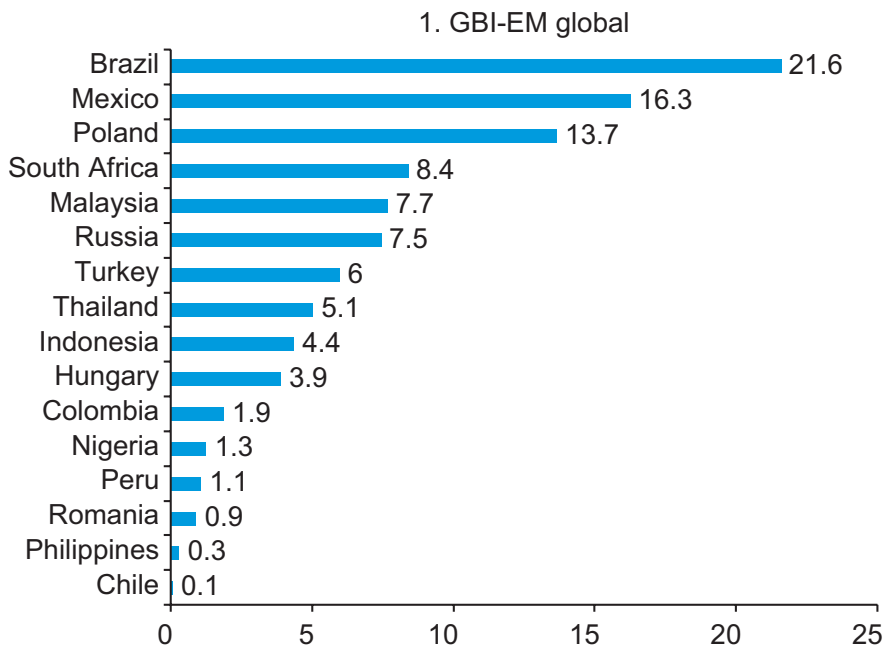

\section{GBI-EM global diversified}

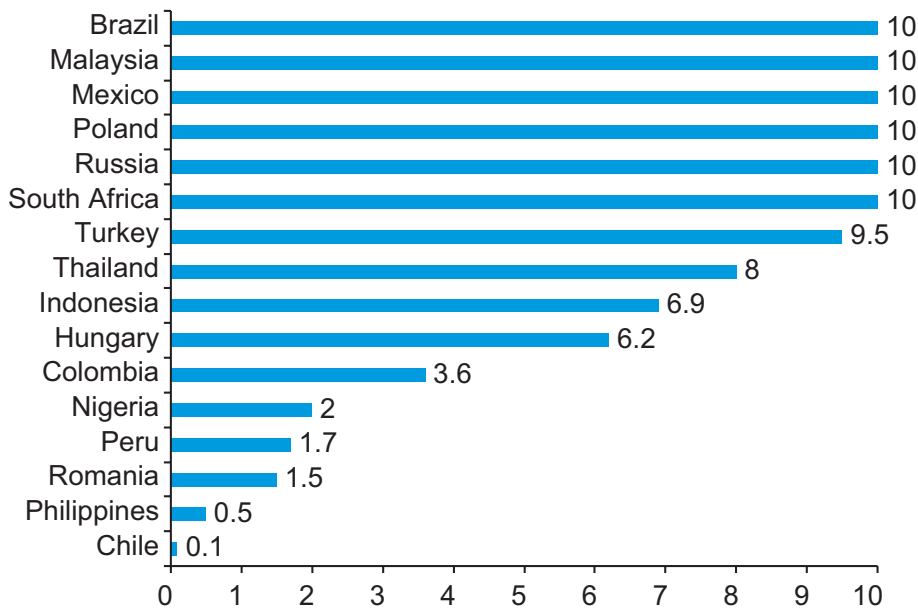

Figure 8.3 Government Bond Index-Emerging Market (GBI-EM) Index Composition (Percent)

Source: Kim (2014).

Each firm establishes its own determinants, considering aspects such as market capitalization, trading activity, investment restrictions, and trading infrastructure. These firms hold periodic reviews to determine whether a country should be included or excluded—or moved into another index group (either promoting or demoting its status). 
TABLE 8.3

\begin{tabular}{|c|c|c|c|c|c|c|c|c|c|}
\hline & FTSE & MSCI & Russell & S\&P & & FTSE & MSCI & Russell & S\&P \\
\hline Argentina & $\checkmark$ & $\checkmark$ & $\checkmark$ & $\checkmark$ & Malta & $\checkmark$ & & $\checkmark$ & \\
\hline Bahrain & $\checkmark$ & $\checkmark$ & $\checkmark$ & $\checkmark$ & Morocco & & $\checkmark$ & & \\
\hline Bangladesh & $\checkmark$ & $\checkmark$ & $\checkmark$ & $\checkmark$ & Mauritius & $\checkmark$ & $\checkmark$ & $\checkmark$ & $\checkmark$ \\
\hline Botswana & $\checkmark$ & & $\checkmark$ & $\checkmark$ & Namibia & & & & $\checkmark$ \\
\hline Bulgaria & $\checkmark$ & $\checkmark$ & $\checkmark$ & $\checkmark$ & Nigeria & $\checkmark$ & $\checkmark$ & $\checkmark$ & $\checkmark$ \\
\hline Colombia & & & & $\checkmark$ & Oman & $\checkmark$ & $\checkmark$ & $\checkmark$ & $\checkmark$ \\
\hline Côte d'Ivoire & $\checkmark$ & & & $\checkmark$ & Pakistan & & $\checkmark$ & $\checkmark$ & $\checkmark$ \\
\hline Croatia & $\checkmark$ & $\checkmark$ & $\checkmark$ & $\checkmark$ & Panama & & & & $\checkmark$ \\
\hline Cyprus & $\checkmark$ & & $\checkmark$ & $\checkmark$ & Papua New Guinea & & & $\checkmark$ & \\
\hline Ecuador & & & & $\checkmark$ & Qatar & $\checkmark$ & $\checkmark$ & $\checkmark$ & $\checkmark$ \\
\hline Estonia & $\checkmark$ & $\checkmark$ & $\checkmark$ & $\checkmark$ & Romania & $\checkmark$ & $\checkmark$ & $\checkmark$ & $\checkmark$ \\
\hline Gabon & & & $\checkmark$ & & Serbia & $\checkmark$ & $\checkmark$ & $\checkmark$ & \\
\hline Ghana & $\checkmark$ & & $\checkmark$ & $\checkmark$ & Slovakia & $\checkmark$ & & $\checkmark$ & $\checkmark$ \\
\hline Jamaica & & & $\checkmark$ & $\checkmark$ & Slovenia & $\checkmark$ & $\checkmark$ & $\checkmark$ & $\checkmark$ \\
\hline Jordan & $\checkmark$ & $\checkmark$ & $\checkmark$ & $\checkmark$ & Sri Lanka & $\checkmark$ & $\checkmark$ & $\checkmark$ & $\checkmark$ \\
\hline Kazakhstan & & $\checkmark$ & $\checkmark$ & $\checkmark$ & Trinidad and Tobago & & & $\checkmark$ & $\checkmark$ \\
\hline Kenya & $\checkmark$ & $\checkmark$ & $\checkmark$ & $\checkmark$ & Tunisia & $\checkmark$ & $\checkmark$ & $\checkmark$ & $\checkmark$ \\
\hline Kuwait & & $\checkmark$ & $\checkmark$ & $\checkmark$ & Ukraine & & $\checkmark$ & $\checkmark$ & $\checkmark$ \\
\hline Lebanon & & $\checkmark$ & & $\checkmark$ & United Arab Emirates & & $\checkmark$ & & $\checkmark$ \\
\hline Lithuania & $\checkmark$ & $\checkmark$ & $\checkmark$ & $\checkmark$ & Vietnam & $\checkmark$ & $\checkmark$ & $\checkmark$ & $\checkmark$ \\
\hline Macedonia & $\checkmark$ & & & & Zambia & & & & $\checkmark$ \\
\hline
\end{tabular}

Source: Index web pages.

Notes: FTSE = Financial Times and London Stock Exchange; $\mathrm{MSCl}=$ Morgan Stanley Capital International; S\&P = Standard \& Poor's.

Frontier markets are decidedly heterogeneous, but they generally fall into three broad groupings:

- Relatively advanced countries with very small markets (Estonia, Mauritius);

- Countries with significant investment restrictions (Argentina; Gulf Cooperation Council, GCC, countries);

- Countries with a relatively low level of development (Bangladesh, Ghana).

The inclusion of markets in GCC member countries in frontier indices may seem somewhat anomalous given their high incomes, but they are prominent (and somewhat predominant given their relative market size) in all four major index groups, given their investment restrictions.

\section{FRONTIER MARKET COUNTRY PROFILES}

What are the common characteristics of frontier markets? Table 8.4 provides a snapshot and useful comparators with emerging and developed markets. Canvassing a broad set of indicators on macro factors, equities, risk, and exposures, frontier markets represent a wide range of general development and show some obvious areas of investor concern (Figure 8.5). 


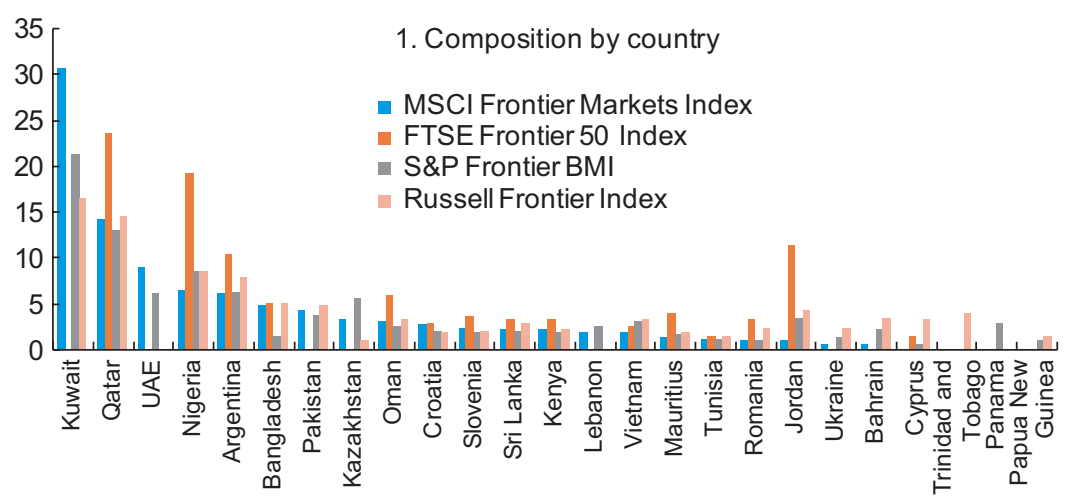

2. Composition by region
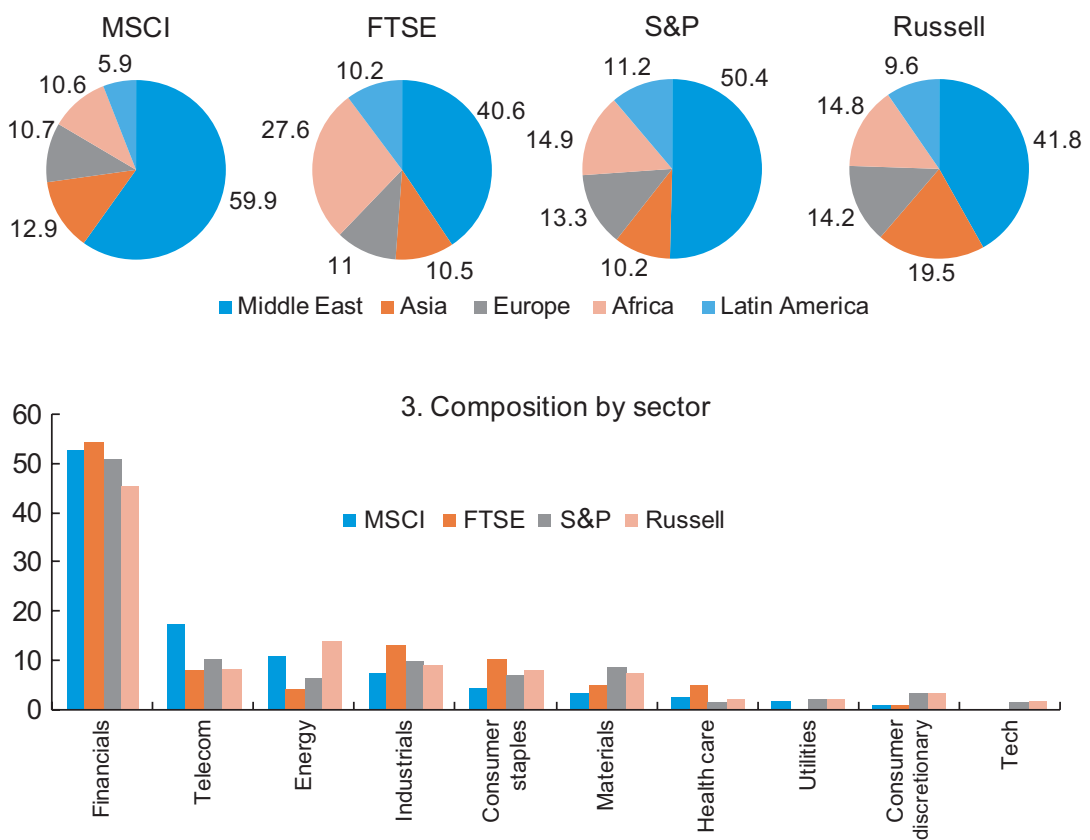

Figure 8.4 Frontier Equity Market Index Composition (Percent)

Source: Buchanan (2012).

Notes: FTSE = Financial Times and London Stock Exchange; $\mathrm{MSCl}=$ Morgan Stanley Capital International; S\&P = Standard \& Poor's; UAE = United Arab Emirates.

\section{Economy}

The economies included in the frontier market universe range in size from a GDP of $\$ 12$ billion for Mauritius to $\$ 488$ billion for Argentina. But the $\$ 3.4$ trillion total for the group is dwarfed by the $\$ 23.6$ trillion for emerging markets and $\$ 42.9$ trillion for developed markets. Per capita incomes in frontier markets range 
Selected Macroeconomic, Equity, Risk, and Exposure Indicators

\begin{tabular}{|c|c|c|c|c|c|c|c|c|c|c|c|c|c|c|c|c|}
\hline \multirow[t]{3}{*}{$\begin{array}{l}\text { Country/ } \\
\text { Group }\end{array}$} & \multicolumn{5}{|c|}{ Macro } & \multicolumn{3}{|c|}{ Equities } & \multicolumn{3}{|c|}{ Risk } & \multicolumn{5}{|c|}{ Exposures } \\
\hline & $\begin{array}{l}\text { GDP } \\
(\$ \text { bn })\end{array}$ & $\begin{array}{l}\text { GDP per } \\
\text { Capita } \\
\text { (\$) }\end{array}$ & $\begin{array}{l}\text { Current } \\
\text { Account } \\
\text { Balance } \\
\text { (\% of GDP) }\end{array}$ & $\begin{array}{l}\text { Gross } \\
\text { General } \\
\text { Govt Debt } \\
\text { (\% of GDP) }\end{array}$ & $\begin{array}{c}\text { Reserves } \\
(\$ \mathrm{bn})\end{array}$ & $\begin{array}{c}\text { Market } \\
\text { Capitalization } \\
\text { (\% of GDP) }\end{array}$ & $\begin{array}{c}\text { Stock } \\
\text { Turnover/ } \\
\text { Market Cap } \\
\text { (\%) }\end{array}$ & $\begin{array}{l}\mathrm{P} / \mathrm{E} \text { ratio } \\
\text { (avg) }\end{array}$ & $\begin{array}{c}\text { Credit } \\
\text { Rating } \\
\text { (avg) }\end{array}$ & $\begin{array}{l}\text { Corruption } \\
\text { Index } \\
\text { (rank) }\end{array}$ & $\begin{array}{l}\text { Political } \\
\text { Risk } \\
\text { Index } \\
\text { (rank) }\end{array}$ & $\begin{array}{l}\text { Portfolio } \\
\text { Flows/ } \\
\text { Market cap } \\
\text { (\%) }\end{array}$ & $\begin{array}{c}\text { European } \\
\text { Loans/ } \\
\text { Total } \\
(\%)\end{array}$ & $\begin{array}{c}\text { Commodities } \\
\text { Exports/Total } \\
(\%)\end{array}$ & $\begin{array}{c}\text { Euro area } \\
\text { Exports/ } \\
\text { Total Exports } \\
(\%)\end{array}$ & $\begin{array}{c}\text { China Exports/ } \\
\text { Total Exports } \\
(\%)\end{array}$ \\
\hline & 2013 & 2013 & 2013 & 2013 & 2013 & 2013 & 2011 & 2013 & 2013 & 2013 & 2014 & 2013 & 2013 & 2012 & 2013 & 2013 \\
\hline Argentina & 488 & 11,766 & -0.9 & 46.9 & 28.3 & 10.0 & 4.8 & 5.5 & $\mathrm{CCC}+$ & 106 & 71 & -4.9 & 83.4 & 30.1 & 9.7 & 7.1 \\
\hline Bahrain & 32 & 27,435 & 12.0 & 43.9 & 5.4 & 52.0 & 1.5 & 15.5 & BBB & 57 & 68 & 9.0 & 85.8 & 83.7 & 3.0 & 0.8 \\
\hline Bangladesh & 141 & 904 & 1.8 & 37.0 & 17.6 & 24.1 & 92.6 & 12.9 & BB- & 136 & 123 & 0.6 & 87.7 & 6.3 & 33.1 & 1.7 \\
\hline Bulgaria & 53 & 7,328 & 2.1 & 17.6 & 18.4 & 10.1 & 3.4 & 5.1 & BBB & 77 & 61 & -6.2 & 98.5 & 25.7 & 45.1 & 2.7 \\
\hline Cambodia & 16 & 1,016 & -8.6 & 28.1 & 4.5 & $\ldots$ & $\ldots$ & $\ldots$ & $\ldots$ & 140 & 43 & $\ldots$ & 95.2 & 2.4 & 22.9 & 25.1 \\
\hline Croatia & 58 & 13,562 & 1.2 & 59.8 & 17.8 & 35.9 & 4.1 & 12.9 & $\mathrm{BB}+$ & 57 & 39 & 11.4 & 98.3 & 16.7 & 50.8 & 0.6 \\
\hline Estonia & 24 & 19,032 & -1.0 & 11.3 & 0.3 & 10.6 & 12.6 & 11.9 & $\mathrm{~A}+$ & 28 & 71 & -5.8 & 99.9 & 18.4 & 31.5 & 0.8 \\
\hline Jordan & 34 & 5,174 & -11.1 & 87.7 & 12.0 & 73.5 & 13.9 & 14.1 & BB- & 66 & 58 & 0.5 & 80.2 & 21.3 & 2.2 & 1.5 \\
\hline Kazakhstan & 220 & 12,843 & 0.1 & 13.5 & 19.4 & 7.1 & 2.1 & 8.6 & $\mathrm{BBB}+$ & 140 & 107 & -38.0 & 61.6 & 77.1 & 36.6 & 22.7 \\
\hline Kenya & 45 & 1,016 & -8.3 & 50.4 & 6.6 & 49.8 & 7.1 & 13.5 & $\mathrm{~B}+$ & 136 & 50 & -0.1 & 74.7 & 59.3 & 13.3 & 0.8 \\
\hline Kuwait & 185 & 47,639 & 38.8 & 5.3 & 32.3 & 55.5 & 19.4 & 16.9 & $A A$ & 69 & 115 & -15.4 & 60.1 & 95.8 & 5.2 & 8.8 \\
\hline Lao P.D.R. & 10 & 1,477 & -29.5 & 60.3 & 0.6 & $\ldots$ & $\ldots$ & $\ldots$ & $\ldots$ & 83 & 32 & $\ldots$ & 44.1 & $\ldots$ & 5.6 & 90.0 \\
\hline Lebanon & 44 & 9,920 & -16.2 & 139.7 & 37.2 & 19.1 & 4.5 & 8.7 & B & 127 & $\ldots$ & 4.1 & 71.5 & 5.6 & 7.6 & 1.0 \\
\hline $\begin{array}{l}\text { Lithuania } \\
\text { Mauritius }\end{array}$ & $\begin{array}{l}48 \\
12\end{array}$ & $\begin{array}{r}16,003 \\
9,160\end{array}$ & $\begin{array}{r}0.8 \\
-9.1\end{array}$ & $\begin{array}{l}39.3 \\
53.8\end{array}$ & $\begin{array}{l}7.9 \\
3.3\end{array}$ & $\begin{array}{r}8.4 \\
80.9\end{array}$ & $\begin{array}{l}5.0 \\
8.0\end{array}$ & $\begin{array}{r}13.0 \\
9.7\end{array}$ & $\begin{array}{l}\mathrm{BBB}+ \\
\mathrm{BBB}+\end{array}$ & $\begin{array}{l}43 \\
52\end{array}$ & $\begin{array}{r}65 \\
135\end{array}$ & $\begin{array}{r}-48.6 \\
0.5\end{array}$ & $\begin{array}{l}98.5 \\
80.2\end{array}$ & $\begin{array}{r}32.4 \\
2.2\end{array}$ & $\begin{array}{l}28.2 \\
39.2\end{array}$ & $\begin{array}{l}0.4 \\
0.6\end{array}$ \\
\hline Mongolia & 12 & 3,972 & -27.9 & 42.7 & 2.1 & 8.7 & 3.4 & $\ldots$ & BBB- & 157 & 120 & $\ldots$ & 74.9 & 93.8 & 2.0 & 24.5 \\
\hline Morocco & 105 & 3,199 & -7.4 & 61.9 & 18.4 & 52.4 & 9.8 & 12.0 & BBB- & 91 & 35 & 0.4 & 96.7 & 27.5 & 55.9 & 1.5 \\
\hline Myanmar & 56 & 869 & -4.9 & 63.1 & 7.1 & $\ldots$ & $\ldots$ & $\ldots$ & $\ldots$ & 127 & 35 & $\ldots$ & 98.7 & 80.9 & 1.6 & 11.0 \\
\hline Nigeria & 286 & 1,692 & 4.7 & 19.4 & 1.2 & 28.6 & 9.2 & 12.2 & BB- & 144 & 65 & 11.7 & 71.5 & 92.2 & 28.7 & 1.5 \\
\hline Oman & 81 & 25,289 & 9.7 & 7.0 & 16.0 & 30.4 & 12.9 & 10.6 & $\mathrm{~A}+$ & 61 & 88 & 0.1 & 84.0 & 85.6 & 1.7 & 38.2 \\
\hline
\end{tabular}




\begin{tabular}{|c|c|c|c|c|c|c|c|c|c|c|c|c|c|c|c|c|}
\hline Pakistan & 239 & 1,308 & -1.0 & 63.1 & 5.3 & 24.6 & 28.6 & 9.3 & B- & 127 & 43 & 0.0 & 89.5 & 7.6 & 14.5 & 11.0 \\
\hline Qatar & 203 & 100,260 & 29.2 & 34.7 & 41.6 & 75.3 & 18.6 & 12.3 & $A A$ & 28 & 103 & -3.8 & 70.7 & 92.6 & 5.7 & 6.2 \\
\hline Romania & 190 & 8,910 & -1.1 & 39.3 & 45.0 & 11.6 & 12.0 & 11.2 & BBB- & 69 & 78 & 23.3 & 97.3 & 10.0 & 52.1 & 1.0 \\
\hline Serbia & 43 & 5,907 & -5.0 & 65.8 & 14.8 & 21.8 & 3.7 & 3.4 & BB- & 72 & 76 & 28.3 & 99.1 & 9.2 & 43.3 & 0.1 \\
\hline Slovenia & 47 & 22,756 & 6.5 & 73.0 & 0.8 & 15.1 & 6.5 & 19.1 & BBB & 43 & 22 & 74.2 & 98.1 & 4.6 & 52.5 & 0.7 \\
\hline Sri Lanka & 66 & 3,162 & -4.1 & 77.7 & 6.7 & 26.9 & 25.1 & 15.1 & $\mathrm{~B}+$ & 91 & 78 & 1.5 & 79.8 & 9.0 & 16.3 & 1.6 \\
\hline Tunisia & 47 & 4,345 & -8.4 & 44.4 & 7.3 & 16.9 & 11.0 & 16.0 & $\mathrm{BB}+$ & 77 & 61 & -0.1 & 96.1 & 27.5 & 60.6 & 1.0 \\
\hline Ukraine & 178 & 3,919 & -9.2 & 41.0 & 18.8 & 8.5 & 14.1 & 3.1 & AA & 26 & 24 & 57.5 & 95.3 & 22.1 & 13.6 & 4.3 \\
\hline UAE & 396 & 43,876 & 14.9 & 12.3 & 68.2 & 47.5 & 15.9 & 12.6 & B- & 144 & 27 & -16.7 & 75.7 & 38.8 & 3.2 & 4.4 \\
\hline Vietnam & 171 & 1,902 & 6.6 & 55.0 & 25.3 & 26.8 & 29.5 & 15.6 & $\mathrm{~B}+$ & 116 & 88 & 4.4 & 56.9 & 21.6 & 15.5 & 11.8 \\
\hline Frontier & 3,436 & 15,704 & 1.8 & 46.2 & 18.3 & 31.7 & 14.5 & 12.1 & BBB- & 84 & 71 & 3.4 & 88.0 & 35.5 & 25.7 & 5.1 \\
\hline Frontier $\mathrm{x}-\mathrm{GCC}$ & 2,680 & 8,173 & -2.6 & 51.2 & 14.9 & 24.3 & 14.6 & 11.1 & $\mathrm{BB}$ & 92 & 75 & 5.5 & 92.5 & 24.8 & 28.3 & 3.5 \\
\hline Frontier Asia & 710 & 1,826 & -8.4 & 58.6 & 8.6 & 22.2 & 21.7 & 13.2 & $\mathrm{~B}+$ & 126 & 99 & -1.7 & 72.5 & 31.7 & 13.9 & 21.2 \\
\hline Emerging & 23,628 & 11,025 & -0.4 & 49.3 & 327.3 & 64.6 & 66.9 & 12.2 & BBB & 75 & 63 & 2.7 & 69.5 & 28.2 & 20.4 & 10.8 \\
\hline Developed & 42,881 & 48,876 & 2.9 & 83.5 & 142.4 & 141.9 & 99.1 & 17.3 & $A A$ & 20 & 19 & -1.5 & 70.9 & 16.6 & 31.5 & 8.4 \\
\hline
\end{tabular}

Sources: Bank for International Settlements; Bloomberg, L.P.; IMF, Direction of Trade Statistics database, International Financial Statistics database, and World Economic Outlook database; national authorities; PRS Group; Transparency.org; World Bank, World Integrated Trade Solution database; and IMF staff estimates.

Note: Groups conform to MSCI index classifications as of the end of December 2013. Frontier Asia includes Bangladesh, Cambodia, Lao P.D.R., Mongolia, Myanmar, Sri Lanka, and Vietnam. GCC = Gulf Cooperation Council; $\mathrm{P} / \mathrm{E}=$ price-to-earnings ratio; $\mathrm{UAE}=$ United Arab Emirates. 

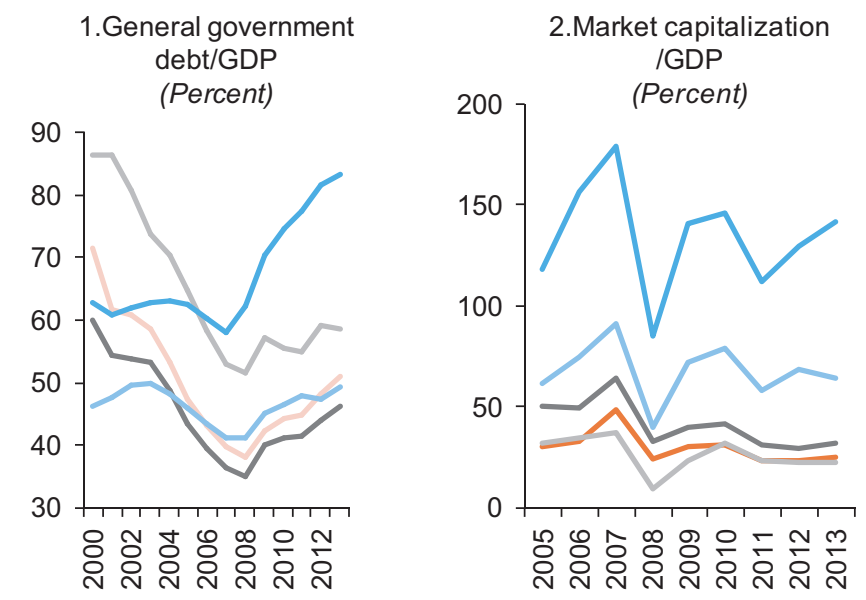

3.Sovereign ratings actions (Net)
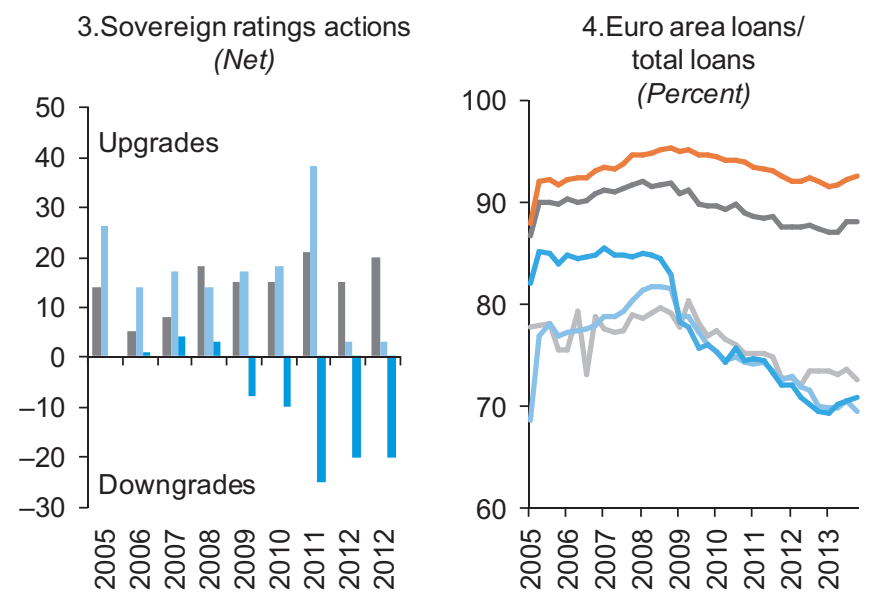

FM FMx-GCC

$-F A$

DM

Figure 8.5 Selected Indicators

Sources: Bank for International Settlements; Bloomberg, L.P.; IMF, World Economic Outlook database; and IMF staff estimates.

Note: $\mathrm{DM}=$ developed markets; $\mathrm{EM}$ = emerging markets; $\mathrm{FA}$ = frontier Asia; $\mathrm{FM}$ = frontier markets; $\mathrm{GCC}=$ Gulf Cooperation Council.

from about $\$ 1,000$ a year (Bangladesh, Kenya) to more than $\$ 100,000$ (Qatar). Excluding GCC countries, frontier markets rank below emerging markets on this score. The GCC factor is also significant when it comes to the current account. Excluding GCC members (which have current account surpluses in double digits largely due to high oil exports), frontier markets have an average current account balance of +1.8 percent of GDP, but only -2.6 excluding the GCC, compared with -0.4 percent for emerging markets and +2.9 percent for developed ones. The frontier debt profile is relatively sanguine and was on a downward trajectory up to 2008 , but has been trending higher since then. Still, at 46.2 percent of GDP

\section{(C) International Monetary Fund. Not for Redistribution}


on average, it is comparable to emerging markets and substantially lower than the 83.5 percent of developed markets. So frontier markets are noticeably low on all measures.

\section{Equity}

Frontier market assets constitute a smallish 1-2 percent of equity assets globally. Market capitalization measured as a percent of GDP is a good proxy for financial sector development and provides a telling reminder that frontier markets are far below the development stage of emerging and developed markets. In 2013, frontier market capitalization was just 32 percent of GDP, compared with 65 percent for emerging markets and 142 percent for developed ones. Liquidity is also a big issue for frontier markets. Turnover as a percent of market capitalization is in the single digits in a large number of frontier markets, with the average of 15 percent far less than for emerging markets (67 percent) or developed markets (99 percent). Equity valuations in reporting frontier Asia markets are broadly in line with those of emerging markets.

\section{Bond Markets}

Asia's frontier bond markets are much smaller and have sovereign credit ratings that are significantly lower than Asia's emerging bond markets. Figure 8.6 shows the size and credit ratings of local currency bond markets in several Asian countries. The frontier markets are characterized by single- or double-B ratings, consistent with frontier markets globally. Asia's emerging bond markets tend to have investment grade ratings. As a share of GDP, Asia's frontier bond markets are generally larger than Africa's, but are notably smaller than Asia’s emerging markets (Figure 8.7).

\section{Frontier Market Performance}

Frontier markets proved surprisingly resilient in 2013, a year in which many emerging markets struggled. Both bond and equity markets outperformed their emerging market counterparts. Frontier equities gained 5.5 percent in the first quarter of 2014, while emerging equities fell 0.8 percent. The outperformance partly reflects the illiquidity of frontier markets, which seems to provide a buffer during periods of sharply diminished risk appetite in global markets. It further reflects off-benchmark investments in these markets and the fact that hedge funds and other investors (especially in equities) follow a different dynamic when investing in frontiers than they do in the more traditional emerging market universe.

The historical record paints a more mixed picture. During the past few years, the risk-return profile of frontier market debt has largely bested that of emerging market debt. This has not been the case on the equity side, where emerging market metrics were generally better (Figure 8.8).

International bond issuance has soared. Many frontier economies came to market, and many were oversubscribed. In 2012, international bond issuance reached record amounts, totaling nearly $\$ 40$ billion. First-time issuers typically 


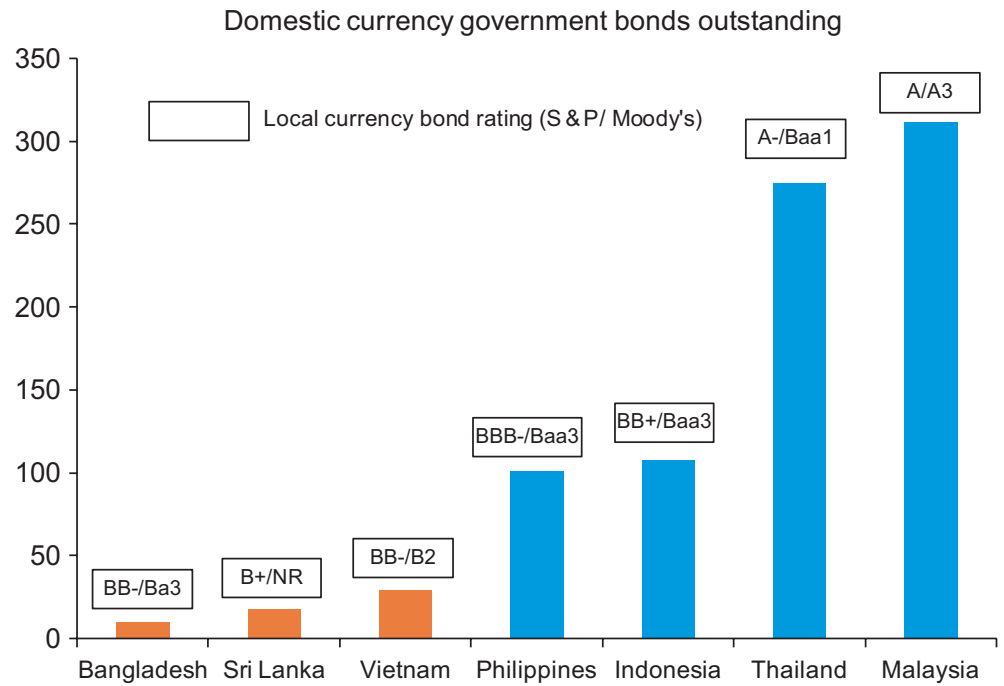

Figure 8.6 Nominal Size and Credit Quality of Asia's Frontier and Emerging Markets (Billions of U.S. dollars)

Source: Asian Development Bank; national authorities; and IMF staff estimates.

Notes: Data are for end-2013 or latest available. S\&P = Standard and Poor's; Moody's = Moody's Investors Service.

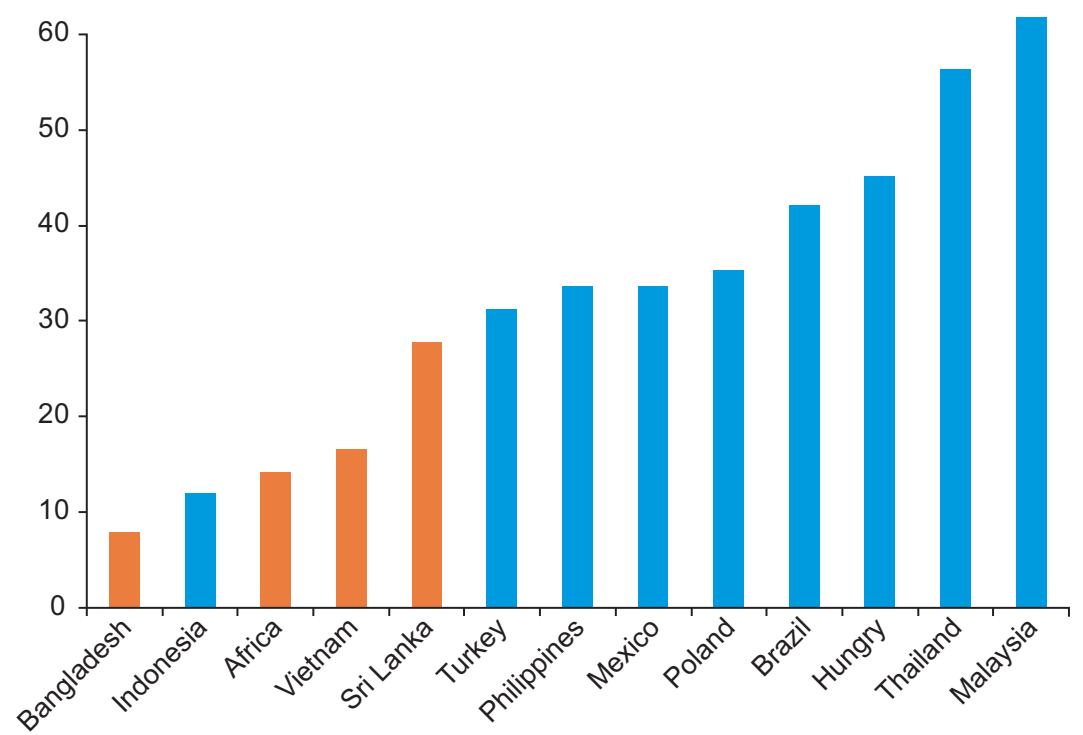

Figure 8.7 Comparison of Global Frontier and Emerging Local Currency Bond Markets (Percent of GDP)

Sources: Asian Development Bank; national authorities; and IMF staff estimates.

Note: Data are for end-2013 or latest available.

\section{CInternational Monetary Fund. Not for Redistribution}




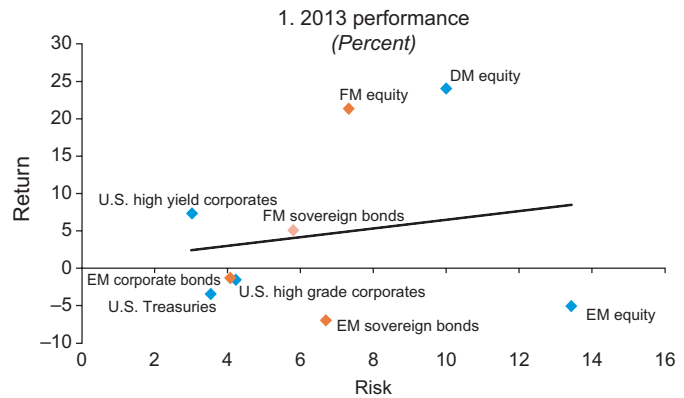

2. 10-year average performance

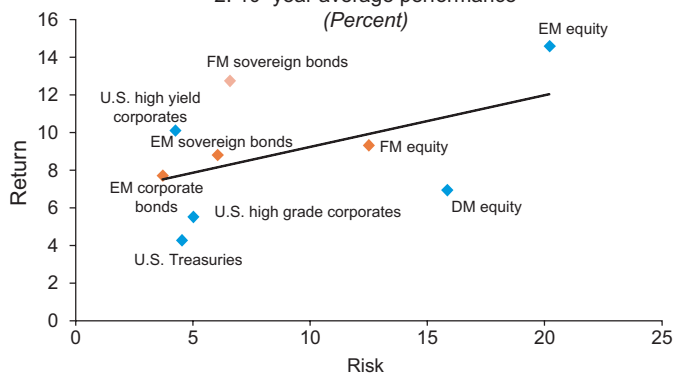

3. Bond Markets

\begin{tabular}{|c|c|c|c|c|c|c|c|c|c|}
\hline & \multicolumn{3}{|c|}{ Treasuries } & \multicolumn{3}{|c|}{ Emerging } & \multicolumn{3}{|c|}{ Frontier } \\
\hline & Return & Risk & Ratio & Return & Risk & Ratio & Return & Risk & Ratio \\
\hline 2004 & 3.5 & 4.5 & 0.8 & 11.7 & 7.6 & 1.5 & 16.1 & 9.0 & 1.8 \\
\hline 2005 & 2.8 & 3.4 & 0.8 & 10.7 & 4.9 & 2.2 & 11.1 & 5.2 & 2.1 \\
\hline 2006 & 3.3 & 2.9 & 1.1 & 9.9 & 3.9 & 2.5 & 12.8 & 3.5 & 3.6 \\
\hline 2007 & 8.8 & 4.1 & 2.2 & 6.3 & 3.6 & 1.7 & 4.5 & 3.2 & 1.4 \\
\hline 2008 & 14.7 & 7.1 & 2.1 & -10.9 & 15.2 & -0.7 & -41.0 & 16.4 & -2.5 \\
\hline 2009 & -3.7 & 6.4 & -0.6 & 28.2 & 5.3 & 5.3 & 74.5 & 6.4 & 11.6 \\
\hline 2010 & 4.7 & 4.7 & 1.0 & 12.0 & 4.9 & 2.5 & 21.8 & 7.4 & 3.0 \\
\hline 2011 & 10.0 & 4.9 & 2.0 & 8.5 & 4.8 & 1.8 & 1.3 & 5.9 & 0.2 \\
\hline 2012 & 2.2 & 3.6 & 0.6 & 18.5 & 3.5 & 5.3 & 21.2 & 2.8 & 7.5 \\
\hline 2013 & -3.3 & 3.5 & -0.9 & -6.9 & 6.7 & -1.0 & 5.1 & 5.8 & 0.9 \\
\hline Average & 4.3 & 4.5 & 0.9 & 8.8 & 6.0 & 2.1 & 12.7 & 6.6 & 3.0 \\
\hline
\end{tabular}

4. Equity Markets

\begin{tabular}{|c|c|c|c|c|c|c|c|c|c|}
\hline & \multicolumn{3}{|c|}{ Developed } & \multicolumn{3}{|c|}{ Emerging } & \multicolumn{3}{|c|}{ Frontier } \\
\hline & Return & Risk & Ratio & Return & Risk & Ratio & Return & Risk & Ratio \\
\hline 2004 & 12.8 & 9.7 & 1.3 & 21.5 & 15.4 & 1.4 & 19.8 & 7.8 & 2.5 \\
\hline 2005 & 7.6 & 8.0 & 0.9 & 30.8 & 12.0 & 2.6 & 72.1 & 16.2 & 4.5 \\
\hline 2006 & 18.0 & 10.0 & 1.8 & 29.0 & 18.2 & 1.6 & -11.5 & 14.9 & -0.8 \\
\hline 2007 & 7.1 & 13.0 & 0.5 & 37.4 & 20.6 & 1.8 & 39.1 & 8.0 & 4.9 \\
\hline 2008 & -42.1 & 33.1 & -1.3 & -55.6 & 40.8 & -1.4 & -54.1 & 24.1 & -2.2 \\
\hline 2009 & 27.0 & 23.3 & 1.2 & 76.3 & 26.5 & 2.9 & 4.5 & 20.5 & 0.2 \\
\hline 2010 & 9.6 & 16.7 & 0.6 & 15.5 & 18.1 & 0.9 & 19.1 & 9.6 & 2.0 \\
\hline 2011 & -7.6 & 21.6 & -0.4 & -17.5 & 22.4 & -0.8 & -22.0 & 10.7 & -2.1 \\
\hline 2012 & 13.2 & 12.7 & 1.0 & 13.8 & 14.6 & 0.9 & 5.1 & 5.8 & 0.9 \\
\hline 2013 & 24.1 & 10.0 & 2.4 & -5.0 & 13.4 & -0.4 & 21.4 & 7.3 & 2.9 \\
\hline Average & 7.0 & 15.8 & 0.8 & 14.6 & 20.2 & 1.0 & 9.3 & 12.5 & 1.3 \\
\hline
\end{tabular}

Figure 8.8 Risk-Return Profiles

Sources: Bank of America Merrill Lynch; Bloomberg, L.P.; J.P. Morgan; Morgan Stanley Capital International; and IMF staff estimates.

Notes: $\mathrm{DM}=$ developed markets; $\mathrm{EM}=$ emerging markets; $\mathrm{FM}=$ frontier markets; U.S. = United States.. 

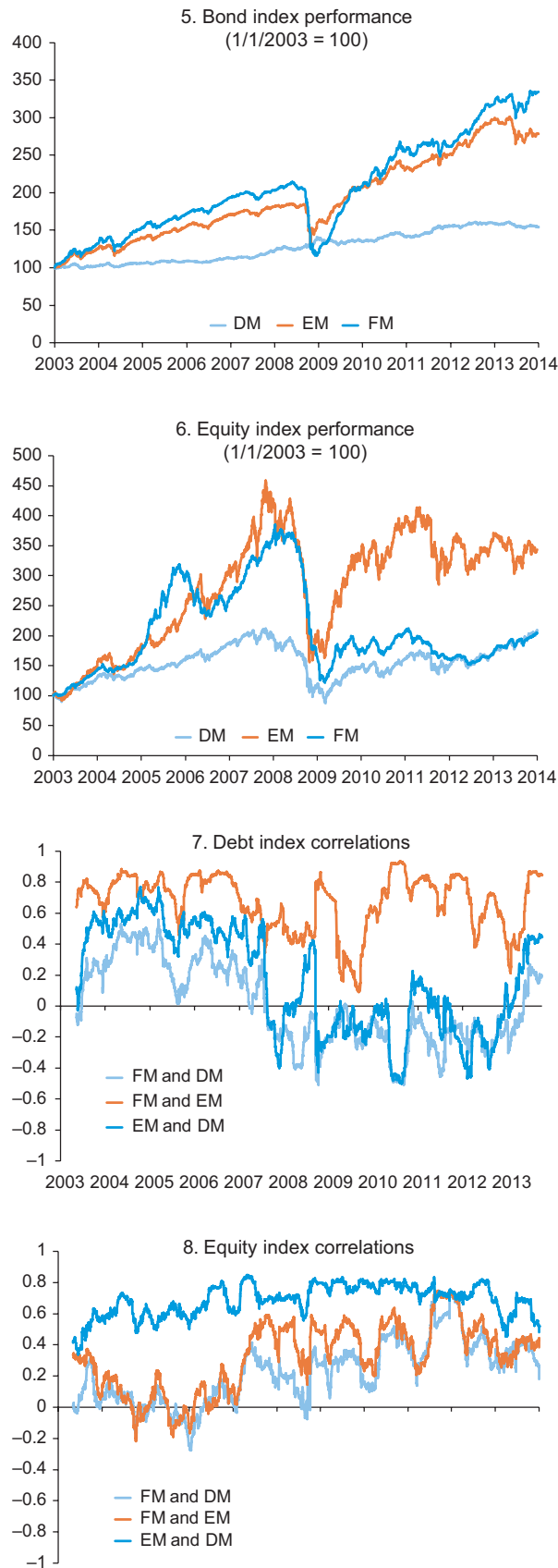

20032004200520062007200820092010201120122013

Figure 8.8 (Continued)

\section{(C) International Monetary Fund. Not for Redistribution}



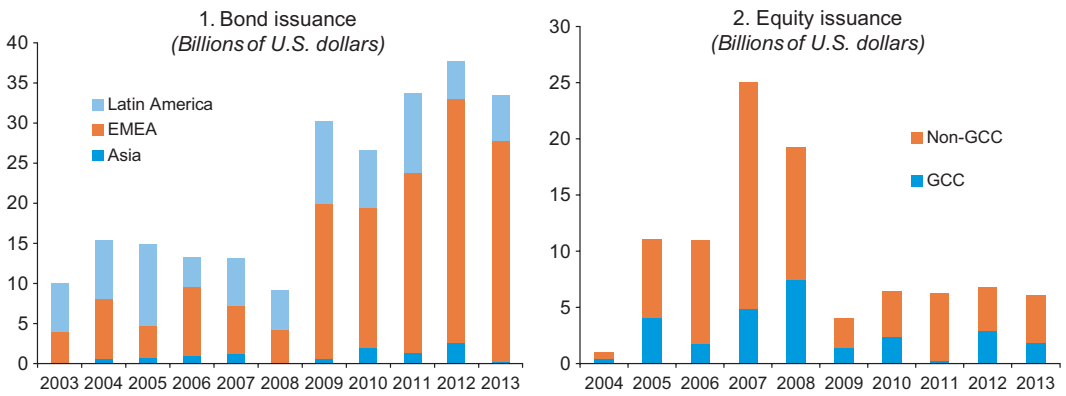

Figure 8.9 International Bond and Equity Issuance

Source: Dealogic.

Notes: $\mathrm{EMEA}=$ Europe, Middle East, and Africa; GCC = Gulf Cooperation Council.

access markets at spreads notably wide of the Emerging Markets Global Bond Index. The higher spreads reflect their weaker credit profiles, poorer secondary market liquidity, poorer transparency, and lack of a capital market financing track record. By contrast internationally, equity issuance has fallen off precipitously since the collapse of Lehman Brothers (Figure 8.9).

\section{Investor Base}

The potential investor base for frontier bond markets has shifted in recent years as low interest rates have pushed money across borders in a global search for yield. Buyers of global investment grade credit have crossed over (and are therefore referred to as crossover investors) to purchase investment grade and relatively liquid emerging market debt (of Brazil, Mexico, and Russia, among othersFigure 8.10), with some even venturing further into frontier markets.

Frontier equity markets represent a more challenging investment environment when compared with the global bond market for emerging market sovereigns. The simple and direct method of buying and selling common stocks in the local market can be problematic for investors, particularly retail ones. ${ }^{3}$ Foreigners may not be allowed to invest directly in some sectors or may be restricted from certain types of investments (especially in banking and strategic industries) or classes of shares. Often there are logistic problems associated with investing in multiple markets, each with its own custodial, financial, and legal system. Depository receipts (either global depository receipts or American depository receipts) represent an alternative avenue to gain exposure to frontier markets. Although there is a wide selection of American and global depository receipts of emerging market countries, the same does not hold for frontier issues.

Mutual funds are a popular channel for investing in frontier markets. A big draw is convenience, as the funds have done the groundwork for investing in

\footnotetext{
${ }^{3}$ Investment restrictions can be found in the IMF Annual Report on Exchange Arrangements and Exchange Restrictions database. http://www.elibrary.imf.org/page/AREAER/www.imfareaer.org.
} 


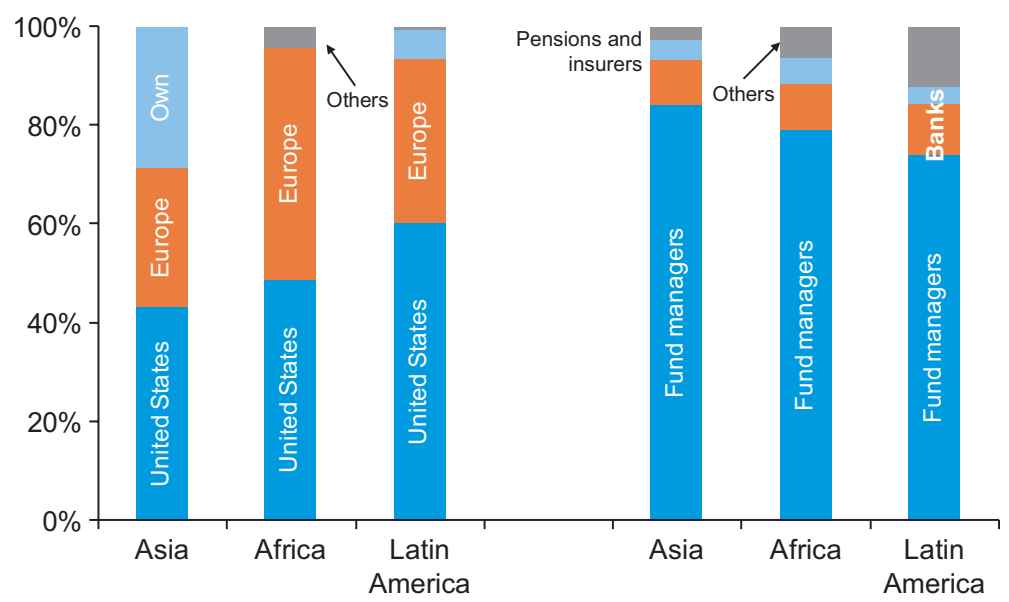

Figure 8.10 Investor Base by Region and Type (Percent)

Sources: IMF, Global Financial Stability Report (October 2013).

Note: Weighted average for deals by Bolivia, Guatemala, Honduras, Mongolia, Nigeria, Paraguay, and Zambia.

different types of global markets, but management fees for frontier markets are relatively high. Emerging Portfolio Research tracks over 80 frontier market funds, but their assets are only about $\$ 10$ billion, compared with about $\$ 700$ billion for emerging market funds. Exchange-traded funds (ETFs) provide another route. While ETFs_-like mutual funds-offer investors an interest in a pool of securities, they represent indices and are passively managed, so ETF redemptions do not trigger tax events as they do for mutual funds. The first frontier market ETF began trading on the London Stock Exchange in early 2008 and has since been joined by several others.

Hedge funds and private equity funds have a history of investment in frontier markets and have made major off-benchmark investments. Since frontier markets are often small, remote, and illiquid, they are not on the radar of most investment banks and analysts. Consequently, niche players such as hedge funds have capitalized on these factors and developed local expertise in these markets to seek out attractive investment opportunities. More recently, sovereign wealth funds, Asian family syndicates, and local market investors have ventured into frontier market investments. These investors are more resilient and less likely to shed their investments given the typical triggers that prompt selling by more traditional institutional investors. These new investors are more likely to be in the market for the long haul.

\section{FROM FRONTIER TO EMERGING MARKET}

What are the criteria for graduating from frontier to emerging market status? Given the high degree of heterogeneity among frontier markets, there is no single standard. Policy conditions include the stability of macroeconomic frameworks 
and the openness of capital and financial accounts. Achieving an investment grade sovereign rating, while neither a necessary nor a sufficient condition, can serve as a dividing line between the two classes of markets.

Prospects for continued capital market development in frontier Asia and other parts of the world are very good, given the growth outlook and positive demographics in many of these countries. But some major challenges need to be overcome. For bond markets, this is a matter of broadening market access to nonresident investors, thereby diversifying sources of funding and increasing depth and liquidity. This can take place via the issuance of domestic or hard currency bonds that nonresident investors are willing to purchase. In the case of hard currency bond markets, investors need to feel that the credit and liquidity risks are manageable. Aside from the credit ratings, this means that investors must be able to assess credit risks and that there is sufficient liquidity in the secondary markets to allow investors to exit if they wish.

When bonds are in local currency, investors also need to understand and manage the exchange rate risk. Most emerging local currency bond markets preferred by investors also tend to have floating exchange rates and a minimum of capital controls. Malaysia, Mexico, South Africa, and Thailand are examples of countries that investors see as established emerging markets for local currency bonds. So far, frontier countries such as Sri Lanka and Vietnam do not have the size or liquidity conditions that encourage nonresident investor participation, and this impedes their development.

Within Asia, Bangladesh, Sri Lanka, and Vietnam appear to be the most likely candidates to graduate from frontier to emerging status. Their local currency bond markets can be compared with Indonesia, Malaysia, Philippines, and Thailand - countries that have established themselves as relatively advanced among emerging markets. All are members of the GBI-EM index (for emerging market local currency debt) and none are in the NEXGEM index (for frontier market hard currency debt).

\section{CONCLUSION AND IMPLICATIONS FOR POLICIES}

Well-regulated and developed markets can be an important catalyst for higher growth rates. Developed bond markets increase the reliability of fiscal financing by increasing both the size and diversity of funding sources, particularly as the share of nonresident investors rises. Greater and timelier disclosure of data and better regulations tend to encourage foreign participation in both bond and equity markets and can facilitate capital flows to the private sector with their own set of benefits (see Chapter 7 on addressing financial sector vulnerabilities). ${ }^{4}$ If accompanied by the appropriate institutional developments in the financial sector, a more developed domestic bond market can improve the transmission and

\footnotetext{
${ }^{4}$ These include the transfer of technology and skills from foreign companies in the case of foreign direct investment.
} 
effectiveness of monetary policy (see Chapter 9 on monetary policy frameworks). Collectively, these developments can reduce financing costs and improve growth profiles.

However, a rapidly growing domestic bond market with a high share of nonresident investors can also cause or exacerbate imbalances in the economy and lead to greater asset price volatility. Greater dependence on nonresident financing (particularly in the absence of sizable gross external assets) may make a country more vulnerable to a reversal of capital flows. Capital flows tend to be procyclical and may merit countercyclical measures during periods of inflows to mitigate the buildup of imbalances. A sharp, persistent reversal of capital flows poses myriad challenges to policymakers in the form of exchange rate volatility, inflation variability, and financial distress. ${ }^{5}$ Countries that have a larger change in the share of nonresident investors tend to experience greater volatility in the returns of domestic bonds. This is particularly true where the domestic investor base (pension funds, assets managers, banks) is not fully developed and the domestic market is characterized by low trading liquidity. ${ }^{6}$

Unconventional monetary policy in some advanced economies and low global interest rates have contributed to a global search for yield, which has benefited some frontier economies. An unwinding of these policies could adversely affect frontier markets. Changes in global risk perception could also have large impacts on frontier markets, with the risk of sudden stops. Countries with more open capital accounts and greater reliance on foreign capital flows could also experience capital outflows.

How then to increase the resilience of frontier markets? Continued improvement in economic fundamentals is one answer, accompanied by strengthening of policy buffers. In many frontier markets, policy frameworks remain relatively weak and have not kept up with the strong growth performance (financial sector regulation and supervision, corporate governance, transparency, provision of timely and reliable data, monetary policy frameworks, budget rules). Progress in these areas is needed not only to develop capital markets, but also to minimize vulnerabilities to shocks going forward.

\section{REFERENCES}

Buchanan, Mark. 2012. Guide to Trading in Frontier Markets. Zurich: Credit Suisse.

International Monetary Fund (IMF). 2012. Global Financial Stability Report. Washington, October.

2013a. "Box 1.2: First-Time Issuers: New Opportunities and Emerging Risk." In Global Financial Stability Report. Washington, October. —. 2013b. World Economic Outlook. Washington, October.

\footnotetext{
${ }^{5}$ The October 2013 World Economic Outlook discusses various characteristics that make some emerging markets more resilient than others to the volatility of capital flows.

${ }^{6}$ See the October 2012 Global Financial Stability Report for an analysis of the impact of nonresident investors and domestic market development on bond market volatility.
} 
Annual Report on Exchange Arrangements and Exchange Restrictions database. http:// www.elibrary.imf.org/page/AREAER/www.imfareaer.org.

Kim, Gloria. 2014. J.P. Morgan Index Product Guide. New York: J.P. Morgan.

Nielsen, Lynge. 2011. "Classifications of Countries Based on Their Level of Development: How It Is Done and How It Could Be Done." IMF Working Paper 11/31, International Monetary Fund, Washington. 
This page intentionally left blank

CInternational Monetary Fund. Not for Redistribution 


\title{
Monetary Policy Frameworks: An Assessment
}

\author{
AshVin Ahuja, Nombulelo Duma, SarWat Jahan, \\ YASUHISA OJIMA, AND AleXANDRA PETER
}

The key features of frontier and developing Asia's development experience since the mid-1990s are its impressive growth performance and relatively wellcontained inflation. ${ }^{1}$ During 1995-2012, the median growth rate for frontier and developing Asia has consistently been more robust and less volatile than that in emerging market Asia (Figure 9.1). However, on the inflation front, frontier and developing Asia does not appear to have enjoyed "the great moderation" before the global financial crisis in 2008 like many of the emerging market economies. Nevertheless, the inflation experience has also become more homogeneous across frontier and developing Asia, both in level and volatility (Figure 9.2).

This chapter focuses on the role of monetary and exchange rate policies adopted by countries in the region in determining growth and inflation outcomes. From the institutional point of view, we find that frontier and developing Asian central banks are predominantly exchange rate targeters, which are not operationally autonomous and tend to place more emphasis on supporting growth than on price stability. That said, our empirical work also reveals that the monetary and exchange rate strategies these countries choose-primarily intermediate exchange rate regimes-are conducive to lower inflation without sacrificing the growth achievement, in terms of both the growth rate and growth volatility.

The chapter begins by characterizing and recording the salient facts around monetary policy regime choices in frontier and developing Asia. The next section provides a brief background of the key institutional frameworks for monetary policy to indicate the relative level of institutional quality, which may help explain the policy regime choices made. Next there is an assessment of the impacts of different exchange rate regimes on growth and inflation outcomes in frontier and developing Asia and a comparison with the experiences in low-income countries in other regions. The final section concludes the chapter.

\footnotetext{
${ }^{1}$ Frontier and developing Asia comprises 11 countries: Bangladesh, Bhutan, Cambodia, Lao P.D.R., Maldives, Mongolia, Myanmar, Nepal, Papua New Guinea, Timor-Leste, and Vietnam.
} 

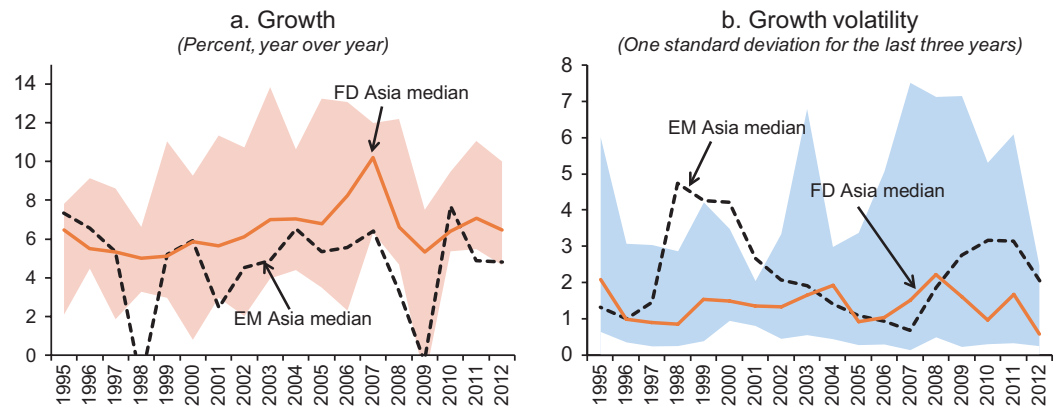

Figure 9.1 Growth: Comparison of Frontier and Developing Asia with Emerging Asia

Sources: Penn World Tables v. 7.1; World Bank, PovcalNet; and IMF staff calculations.

Note: The standard deviation measures how spread out numbers are. The higher the standard deviation, the higher the level of volatility. $\mathrm{FD}=$ frontier and developing, $\mathrm{EM}=$ emerging market.
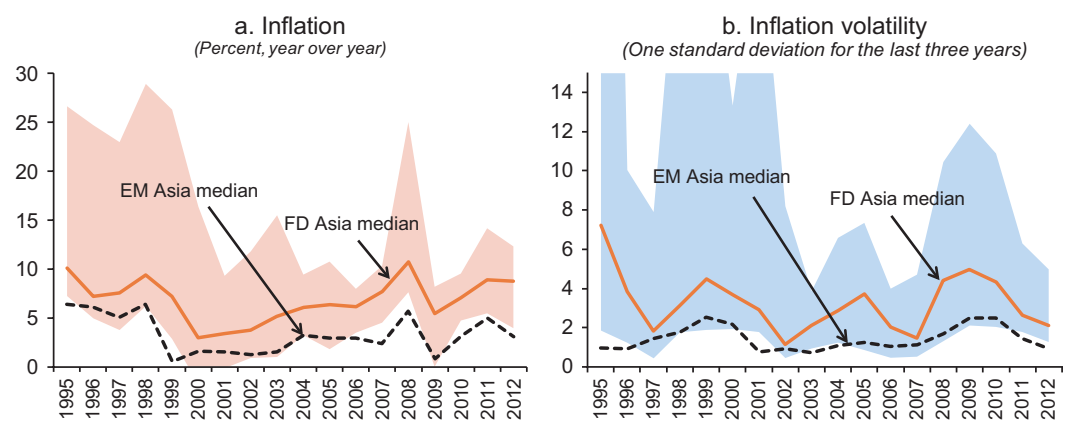

Figure 9.2 Inflation: Comparison of Frontier and Developing Asia with Emerging Asia

Sources: Penn World Tables v. 7.1; World Bank, PovcalNet; and IMF staff calculations.

Note: The standard deviation measures how spread out numbers are. The higher the standard deviation, the higher the level of volatility. $\mathrm{FD}=$ frontier and developing, $\mathrm{EM}=$ emerging market.

\section{CHARACTERIZING MONETARY POLICY}

While low-income countries have shifted more toward flexible exchange rates, exchange rate stability remains the primary objective in the majority of frontier and developing Asia’s central banks. Intermediate exchange rate regimes continue to be predominant in these countries (Figure 9.3).

In addition, a few frontier and developing Asia central banks pursue other objectives, including promoting economic growth and price stability. In several cases, it remains unclear which objective is the overriding one, and there can be potential conflicts. It is also notable that only a few frontier and developing Asian central banks have price stability as the overriding policy mandate (Bhutan, Papua New Guinea, Timor-Leste). This general lack of focus on price stability is consistent with the relatively high and volatile inflation experience observed during 1995-2012 when compared with emerging Asia (Table 9.1). 


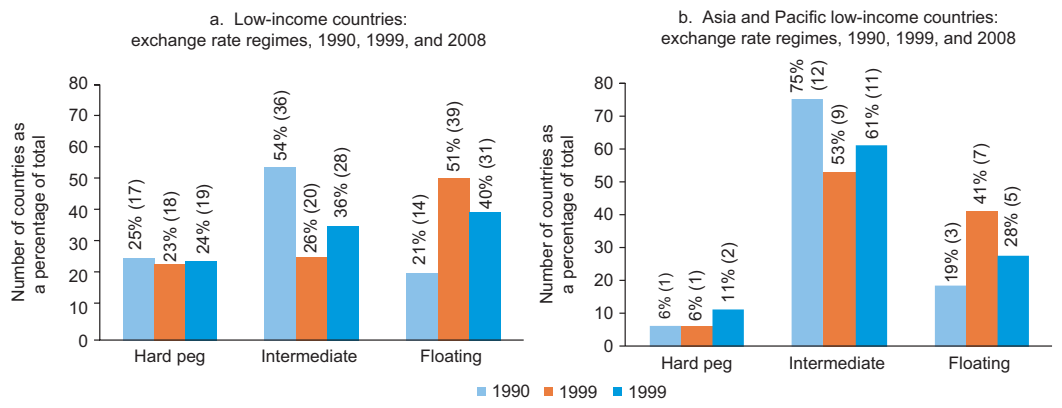

Figure 9.3 Exchange Rate Regimes (Percent)

Source: Authors' calculations based on IMF, Annual Report on Exchange Arrangements and Exchange Restrictions database.

TABLE 9.1

\begin{tabular}{|c|c|c|c|c|c|}
\hline \multicolumn{6}{|c|}{ Monetary Policy Regime } \\
\hline & $\begin{array}{l}\text { Exchange } \\
\text { Rate } \\
\text { Targeting }\end{array}$ & $\begin{array}{l}\text { Monetary } \\
\text { Aggregate } \\
\text { Targeting }\end{array}$ & $\begin{array}{l}\text { Inflation } \\
\text { Targeting }\end{array}$ & $\begin{array}{c}\text { De Facto Exchange Rate } \\
\text { Regime }\end{array}$ & $\begin{array}{l}\text { Forward Foreign } \\
\text { Exchange Market }\end{array}$ \\
\hline Bangladesh & & - & & Other managed & - \\
\hline Bhutan & - & & & Conventional peg & \\
\hline Cambodia & - & & & Stabilized arrangement & \\
\hline Lao P.D.R. & - & - & & Stabilized arrangement & \\
\hline Maldives & - & & & Stabilized arrangement & \\
\hline Mongolia & & & & Floating & • \\
\hline Myanmar & - & - & & Other managed & \\
\hline Nepal & - & & & Conventional peg & - \\
\hline Papua New Guinea & & - & & Floating & - \\
\hline Timor-Leste & - & & & No separate legal tender & \\
\hline Vietnam & - & - & & Stabilized arrangement & - \\
\hline
\end{tabular}

Sources: IMF, Annual Report on Exchange Arrangements and Exchange Restrictions database; and IMF staff survey. Note: Mongolia set monetary aggregate targeting during the IMF supported program.

This primary focus on the exchange rate is consistent with the greater stability of the nominal exchange rate during 1996-2009. Moreover, frontier and developing Asia as a whole has steadily become more financially open. ${ }^{2}$ These developments come at the expense of the ability to determine short-term domestic interest rates independently.

The group's experience remains heterogeneous, however, with three distinct policy strategies (Figure 9.4): the first-also the majority-adopts a fixed or intermediate exchange rate regime and retains domestic monetary control at the expense of financial openness. Pursuing this strategy are Bangladesh, Bhutan, Lao P.D.R., Myanmar, Nepal, and Vietnam. The second floats the exchange rate and

\footnotetext{
${ }^{2}$ The trilemma index reflects the well-known "impossible trinity," which posits a trade-off between two of the following three policy dimensions: monetary independence (or domestic monetary control), exchange rate stability, and financial openness (Aizenman, Chinn, and Ito 2008).
} 

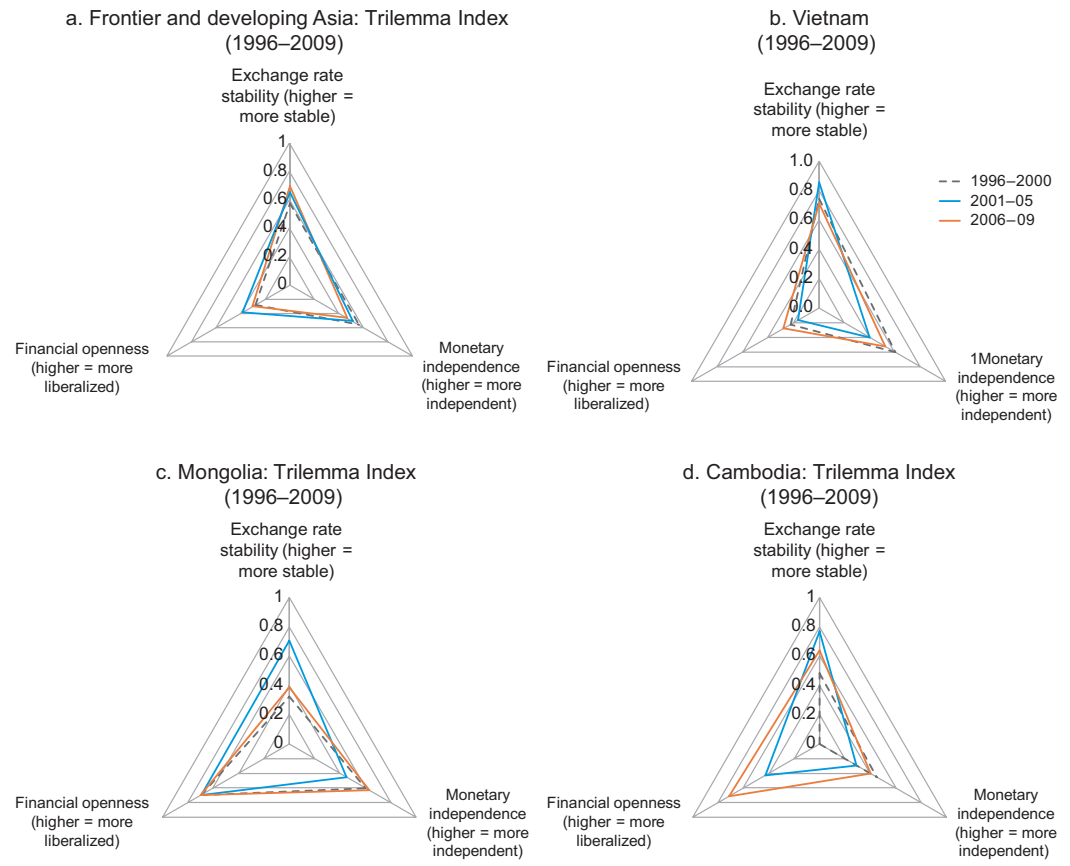

Figure 9.4 The Trilemma Indexes

Source: Updated database based on Aizenman, Chinn, and Ito (2008).

pursues financial openness while retaining high degrees of domestic monetary control. This group is represented by Mongolia and Papua New Guinea. The third strategy — maintaining a stable exchange rate with increasingly open financial markets—is employed by Cambodia and Maldives.

\section{INSTITUTIONAL FRAMEWORKS FOR MONETARY POLICY}

We find that frontier and developing Asia's institutional frameworks for monetary policy remain rudimentary and that there is a general lack of operational autonomy for central banks.

\section{Central Bank Autonomy}

Overall, the degree of operational autonomy of frontier and developing Asian central banks is limited. In some countries, central bank governors are members of the cabinet (Lao P.D.R., Vietnam). In some countries, where there is a central bank board of directors, government representatives could occupy over a third of the board seats (Bangladesh, Bhutan, Myanmar). While monetary policy is determined by the government in some cases (Bhutan, Lao P.D.R.), in others, decisions require government approval (Vietnam, for example). For most central

\section{(C) International Monetary Fund. Not for Redistribution}


banks, lending to the government is restricted or allowed provided repayment takes place within three to six months. In Timor-Leste, lending to the government is not allowed.

Central banks are mostly granted some level of financial autonomy. In most central banks, the integrity of their capital is protected through a mechanism that allows for compensation from the government. In most cases, the government can issue marketable securities to raise funds to cover a central bank loss. Two of the eleven central banks do not have provisions for the government to cover their losses (Bangladesh, Myanmar). Most central banks can determine their own budget. In the case of Bangladesh, the budget requires approval by a government auditor, while in Cambodia and Vietnam, government approval is required.

\section{Monetary Policy Objectives}

The monetary policy regime in most of frontier and developing Asia includes the exchange rate as the nominal anchor. While some countries have the exchange rate clearly specified as the nominal anchor (Bhutan, Cambodia, Maldives, Nepal), a few others have mixed regimes with targets for monetary aggregates (Lao P.D.R., Vietnam; Box 9.1). Timor-Leste is fully dollarized. Cambodia, Lao P.D.R., and Vietnam are partially dollarized. ${ }^{3}$ Of the exchange-rate-targeting countries, Bhutan and Nepal have conventional pegs to the Indian rupee. Few countries have monetary aggregate targeting as the overarching monetary policy regime (Bangladesh, for example).

\section{Monetary Policy Implementation}

Though central banks in most of frontier and developing Asia do not have autonomy to determine monetary policy, they are responsible for its implementation. Few countries have any form of financial programming that guides decisions on monetary policy. Further, the central banks' autonomy in determining the monetary program varies. In Bangladesh, the governor approves the financial program every July. In the majority of countries, the board of directors decides on the monetary program (Maldives) and/or implements monetary policy (Bangladesh, Bhutan, Cambodia, Maldives, Mongolia, Nepal). In Papua New Guinea, the government proposes the financial program, and the governor is expected to advise or update the minister of finance during its implementation.

Some frontier and developing Asian central banks have liquidity forecasting frameworks. Bhutan, Maldives, Mongolia, Nepal, and Papua New Guinea have some form of liquidity forecasting in place to help guide monetary policy decisions. The frequency of liquidity forecasting varies from daily (Mongolia) to weekly and biweekly (Papua New Guinea). Liquidity forecasting can form a basis for formulating forward-looking monetary policy and support interest rate policy in countries with low levels of dollarization and a functioning monetary transmission mechanism.

\footnotetext{
${ }^{3}$ Cambodia is the most dollarized of the three, with foreign currency deposits estimated at over 80 percent of broad money as of early 2013 .
} 


\section{Box 9.1 The Formulation and Implementation of Monetary Policy in Vietnam}

The current framework: Like many frontier and developing Asian economies, Vietnam has a mixed monetary policy regime with elements of both monetary and exchange rate targeting. In formulating policy, the State Bank of Vietnam (SBV) takes the National Assembly's targets for growth and inflation for the following year as given and estimates the trajectories of monetary aggregates and credit, which it then monitors regularly. A range of instruments-multiple policy interest rates, differentiated reserve requirements, and open market operations-as well as administrative controls are used. In essence, bank credit is an intermediate target, as in monetary-targeting regimes, but the SBV also announces a daily official U.S. dollar-Vietnamese dong exchange rate.

How effective has monetary policy been? To identify the influence of various monetary factors on inflation and growth, a vector autoregressive model is estimated that relates
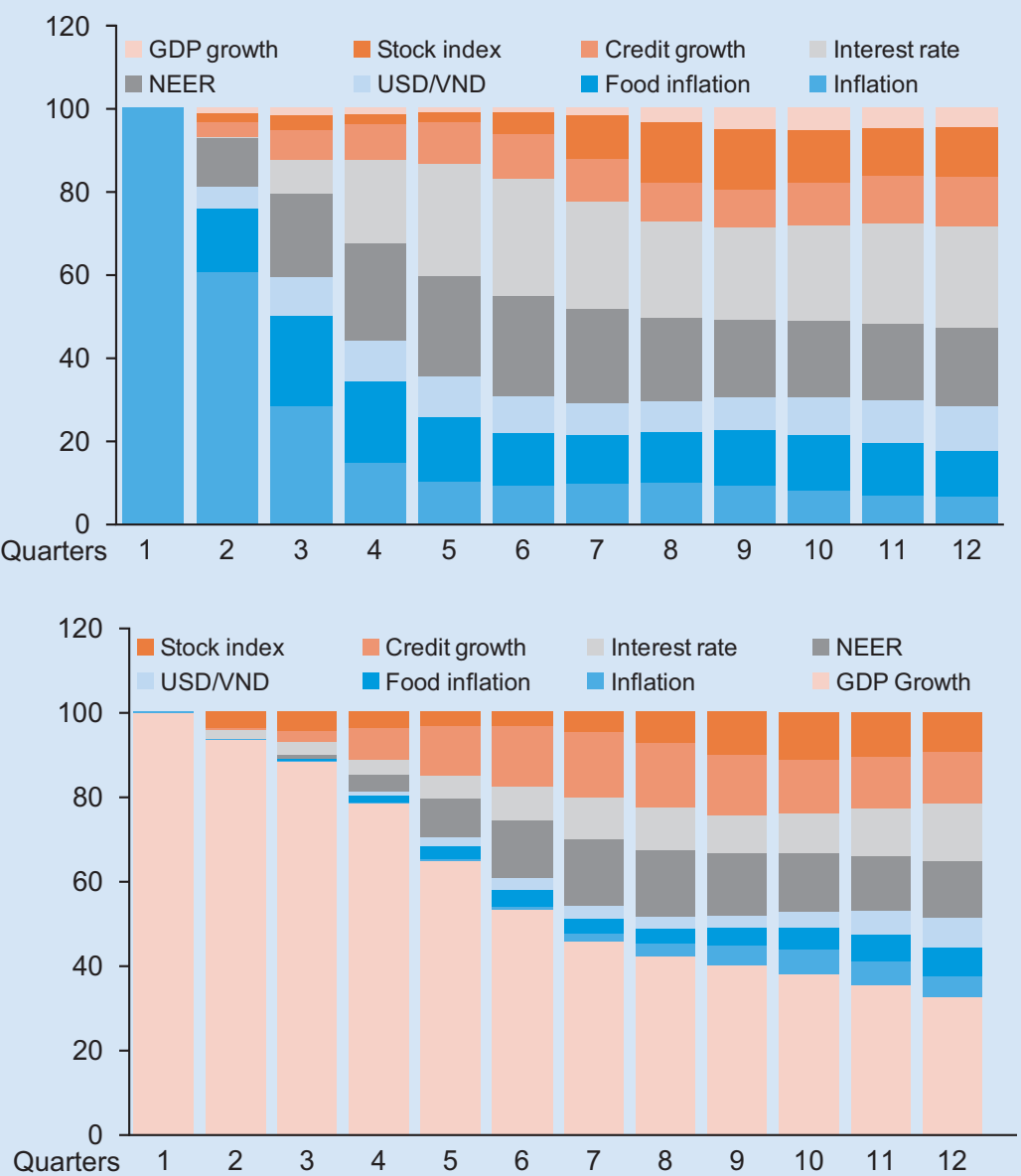

Figure 9.1.1 Variance Decomposition of Inflation Process (Percent)

Sources: Bloomberg, L.P.; IMF, World Economic Outlook database; and Vietnamese authorities.

Notes: $\mathrm{NEER}=$ nominal effective exchange rate; USD = U.S. dollar; VND = Vietnamese dong. 


\section{Box 9.1 The Formulation and Implementation of Monetary Policy} in Vietnam (Continued)

inflation to GDP growth, stock market prices, fuel prices, and monetary factors such as credit growth, interest rates, the nominal effective exchange rate, and the dollar-dong exchange rate during 2005:Q1-2012:Q4. The results suggest that Vietnam's inflation is a monetary phenomenon; that is, inflation is influenced largely by monetary factors from three quarters onward. However, GDP growth tends to be persistent and is influenced mostly by nonmonetary factors during the first six to eight quarters, complicating monetary policy fine-tuning of growth. Among monetary variables, the exchange rate appears to have a sizable and more immediate pass-through to inflation.

What might a more robust framework look like? With a severely impaired credit channel, interest rates and sterilized intervention can be used to support the exchange rate anchor, which would help contain inflation. To help absorb shocks, the exchange rate could be allowed to move in an increasingly wider band. Focusing the SBV's policy mandate on achieving low and stable inflation over the medium term, increasing its operational autonomy, and strengthening its accountability framework would establish policy credibility. In the medium and long term, it may be necessary to reconsider the status of the SBV and its relationship with the government in the formulation and implementation of monetary policy with a view toward greater central bank autonomy.

Source: Ahuja, Duma, and Ha (2013).

\section{Accountability and Transparency}

Accountability and transparency of policies and decisions is lacking in most of the central banks. Few central banks publish their monetary policy decisions immediately after they are made. Most central banks use either their annual reports or other documents to communicate policy decisions to the public. Only Vietnam issues a press release immediately after making monetary policy decisions.

\section{ASSESSING ECONOMIC PERFORMANCE OF DIFFERENT MONETARY POLICY STRATEGIES}

\section{Introduction}

In this section, we analyze how different monetary and exchange rate policy strategies impact macroeconomic performance-specifically how the regimes perform on inflation, per capita GDP growth, and GDP growth volatility outcomes. For this purpose, we rely on the de facto classification of the exchange rate regimes (Table 9.2). This exercise is done for all low-income countries, with a specific focus on frontier and developing Asian economies.

Traditionally, the discussion about exchange rate regimes has revolved around the trade-off between a credible regime and the power to control monetary policy independently so as to insulate the economy from shocks. This debate has shifted recently to discussing the trade-off between inflation and growth (Calderon and Schmidt-Hebbel 2003). A fixed exchange rate may improve the credibility of 
TABLE 9.2

\begin{tabular}{lccc}
\hline \multicolumn{3}{l}{ Classification of Low-Income Countries' Exchange Rate Regimes } \\
\hline \multicolumn{4}{l}{ All Low-Income Countries } \\
\cline { 2 - 4 } & Hard peg & De jure classification \\
\cline { 2 - 4 } & & Intermediate & Floating \\
\cline { 2 - 4 } De facto classification & 321 & 0 & 0 \\
Hard peg & 1 & 248 & 176 \\
Intermediate & 1 & 42 & 495 \\
Floating & 323 & 290 & 671 \\
\hline Total & 99.4 & 85.5 & 73.8 \\
\hline Percentage consensus & & & \\
\hline
\end{tabular}

\begin{tabular}{lccc}
\hline Low-Income Countries Outside Asia and the Pacific \\
\cline { 2 - 4 } & \multicolumn{3}{c}{ De jure classification } \\
\cline { 2 - 4 } & Hard peg & Intermediate & Floating \\
\cline { 2 - 4 } De facto classification & 297 & 0 & 0 \\
Hard peg & 1 & 130 & 113 \\
Intermediate & 1 & 26 & 408 \\
Floating & 299 & 156 & 521 \\
\hline Total & 99.3 & 83.3 & 78.3 \\
\hline Percentage consensus &
\end{tabular}

Low-Income Asia and Pacific Countries

\begin{tabular}{lccc}
\hline & \multicolumn{3}{c}{ De jure classification } \\
\cline { 2 - 4 } & Hard peg & Intermediate & Floating \\
\cline { 2 - 4 } De facto classification & 24 & 0 & 0 \\
Hard peg & 0 & 118 & 63 \\
Intermediate & 0 & 16 & 87 \\
Floating & 24 & 134 & 150 \\
\hline Total & 100 & 88.1 & 58.0 \\
Percentage consensus & & & \\
\hline
\end{tabular}

Source: Authors' calculations based on Annual Report on Exchange Arrangements and Exchange Restrictions database. Note: The exchange rate classifications are for the time period 1990-2007. The de facto classification is based on Bubula and Ötker-Robe (2002) for the period before 1999 and on the IMF's Annual Report on Exchange Arrangements and Exchange Restrictions (AREAER) for the period after 1999. The de jure classification is based on the period before 1999 and on Anderson (2009) for the period after 1999. Definitions of hard peg, intermediate, and floating regime can be found in Appendix Table A9.1.

monetary policy and lower inflation, whereas it is asserted that flexible exchange rates are able to enhance growth and reduce output volatility by allowing the exchange rate to work as a shock absorber (Calderon and Schmidt-Hebbel 2003; Levy-Yeyati and Sturzenegger 2003). However, it is also possible that flexible exchange rates add to economic volatility. Growth could be higher over time under fixed regimes due to lower transaction costs, interest rates, and uncertainty (Rogoff and others 2004).

Empirical studies analyzing the effects of exchange rate regimes on macroeconomic performance have not yielded conclusive answers. Depending on the exchange rate classification methodology, time period used, and country sample, fixed, flexible, or intermediate regimes deliver the best economic performance 
(Frankel 2010; Rogoff and others 2004). For example, Ghosh, Gulde, and Wolf (2003) find fixed exchange rate regimes associated with significantly lower inflation, but no significant effect on economic growth (using a de jure classification); Levy-Yeyati and Sturzenegger (2003) find higher growth under flexible exchange rates (using their de facto classification). ${ }^{4}$

We find that a country's choice of exchange rate regimes can have a significant effect on the inflation outcome in that country, but the effects on economic growth and output volatility appear to be smaller and not always statistically significant. The effects for frontier and developing Asia by and large appear to be similar to those observed in other regions. Specifically, our results show that hard pegs and intermediate regimes are associated with significantly lower inflation compared with floating regimes. However, intermediate regimes are not associated with significantly different GDP growth or growth volatility compared with floating regimes. Hard pegs, on the other hand, are associated with lower output volatility than floating regimes, but also with weaker growth.

\section{Data and Regression Setup}

To assess how exchange rate regimes affect economic performance, we regress the de facto exchange rate regimes on three performance indicators: inflation, per capita real GDP, and real GDP growth volatility, controlling for other factors that influence these indicators. To exclude the recent financial crisis period, the sample period is 1990-2008. The sample includes all countries on the Poverty Reduction Growth Trust list as of 2008, which covers 78 countries. $^{5}$

The data used in this regression are mostly drawn from the IMF's World Economic Outlook database. Table A9.1 provides a detailed description of all variables used in the regression and their sources.

The regression specification follows Calderon and Schmidt-Hebbel (2003). To check for robustness, we also use the determinants specified in Ghosh, Gulde, and Wolf (2003) and Rogoff and others (2004), noted as Specification 2. Since macroeconomic performance could also influence the choice of a particular exchange rate regime, our setup controls for endogeneity. First, a multinomial logit is estimated for hard pegs and intermediate regimes, treating "floating" as the numeraire. In a second step, these adjusted probabilities are used in an instrumental-variable (IV) regression for inflation, GDP per capita growth, and output volatility. ${ }^{6}$ All regressions include time fixed effects.

\footnotetext{
${ }^{4}$ Other work analyzing the effects of exchange rate regimes on inflation and growth include among others Levy-Yeyati and Sturzenegger (2001, 2003), Bailliu, Lafrance, and Perrault. (2003), Courdert and Dubert (2005), Bleaney and Francisco (2007), Petreski (2009), Harms and Kretschmann (2009), and Ghosh, Ostry, and Tsangarides (2010). See Rogoff and others (2004) for an overview of the earlier literature.

${ }^{5}$ Table A9.2 lists all countries included in this analysis.

${ }^{6}$ The adjusted probabilities for the exchange rate regimes from the multinomial regression are used as instruments for the exchange rate regime, while the other control variables are not instrumented (including lags of other control variables because their instruments does not change the results much in most cases).
} 
The multinomial logit regression's independent variables are widely used in the literature (for example, see Poirson 2001; Juhn and Mauro 2002; and Rogoff and others 2004, for an overview) and specified in Calderon and Schmidt-Hebbel (2003). In particular, we use the relative size of a country compared to the United States, a country's geographical area, its ratio of international reserves to imports, the ratio of quasimoney to money, the degree of trade openness, and dummies for landlocked countries and islands. ${ }^{7}$

Our baseline regression for inflation has the following form:

$$
\pi_{t}=\beta_{0}+\beta_{1} H P e g+\beta_{2} I n t+\beta_{3} \pi_{t-1}+\beta_{4} \Delta g+\beta_{5} \Delta m+\beta_{6} T O+\varepsilon .
$$

Inflation $\pi_{t}$ is defined as $\pi_{C P I} /\left(1+\pi_{C P I}\right)$, in which $\pi_{C P I}$ is the rate of change of the consumer price index. HPeg and int are dummies that represent the exchange rate anchor, which are hard peg or intermediate regime, respectively. These two regimes are compared against the base regime, the floating regime. We control other factors that influence inflation, such as lagged inflation $\left(\pi_{t-1}\right)$, money growth $\left(\Delta_{m}\right)$, real GDP growth $\left(\Delta_{g}\right)$, and trade openness $(T O)$.

The regression for per capita growth follows a similar setup:

$$
\begin{aligned}
\Delta g_{t}^{p c}= & \beta_{0}+\beta_{1} \text { HPeg }+\beta_{2} \text { Int }+\beta_{3} \Delta g_{t-1}^{p c}+\beta_{4} T O+\beta_{5} \text { Invest } R \\
& +\beta_{6} \text { ToT }+\beta_{7} G B+\beta_{8} \text { Tax }+\varepsilon .
\end{aligned}
$$

The determinants of GDP growth include the two dummies for the exchange rate regime, the lagged value of GDP growth, and the degree of openness. In addition, we include the investment ratio (InvestR), terms-of-trade shocks (TOT), the fiscal balance $(G B)$, and the tax ratio (Tax).

Finally, the baseline equation for output volatility is

$$
\begin{aligned}
s d\left(\Delta g_{t}\right)= & \beta_{0}+\beta_{1} \text { HPeg }+\beta_{2} \operatorname{Int}+\beta_{3} s d\left(\Delta g_{t-1}\right)+\beta_{4} T O \\
& +\beta_{5} s d(\text { Invest } R)+\beta_{6} s d(\text { ToT })+\beta_{7} G B+\beta_{8} \text { Tax }+\varepsilon,
\end{aligned}
$$

in which we use the same determinants as in the growth regression, except that the volatilities of the investment ratio and of the terms of trade are used instead of their levels. Volatilities are defined as the three-year centered standard deviation of the variables.

We also include a dummy variable $(A P D)$ for frontier and developing Asian economies, both independently and interacted with the exchange rate regime dummy, to measure the difference between these economies and other low-income

\footnotetext{
${ }^{7}$ Variables having a significant impact for exchange rate regime choice include relative size (for hard pegs), the international reserves to imports ratio, the ratio of quasimoney to money (for intermediate regimes), and the dummies for landlocked countries (for intermediate regimes) and islands. The variables mainly have the expected signs. For example, smaller countries or countries that are islands are more likely to have a hard peg.
} 
countries' predictions. However, we do not include the only hard peg in frontier and developing Asia in this exercise due to data limitations.

\section{Results}

The impact of exchange rate regimes on inflation, GDP growth, and output volatility are shown in Figures 9.5, 9.6, and 9.7 and Tables 9.3, 9.4, and 9.5. The coefficients on the dummy variables for hard peg and intermediate regime represent the impact of the respective regime relative to the floating exchange rate regime. Similarly, the coefficient on the APD dummy shows how the economic performance of Asian frontier economies with floating regimes differs from the economic performance of other countries with floating regimes. How Asian frontier economies with intermediate regimes perform compared with other countries with floating regimes is shown by the sum of the coefficients of the intermediate regime dummy, the $A P D$ dummy, and the interaction term.

We find a statistically significant negative impact of hard pegs and intermediate regimes on inflation. Countries with a hard peg or an intermediate regime are associated with inflation rates that are 5.3 percent and 6.1 percent lower than countries with a floating regime (Figure 9.5). This result is robust to including a dummy for frontier and developing Asia. In that regression, the coefficient for hard pegs does not change, but intermediate regimes in other regions are now associated with even lower inflation of 8.6 percent compared with floating regimes in other regions. Frontier and developing Asian economies with an intermediate regime have lower inflation of 3.9 percent, and Asian frontier economies with a floating regime have 1.5 percent lower inflation than countries in other regions with a floating regime. However, these results are not statistically significant.

The effects of exchange rate regime choices on inflation are in line with results by Rogoff and others (2004), which rely on the de facto exchange rate regime measure developed in Reinhart and Rogoff (2004); by Ghosh, Gulde, and Wolf (2003), who find similar results using de jure exchange rate regimes; and by

a. Baseline

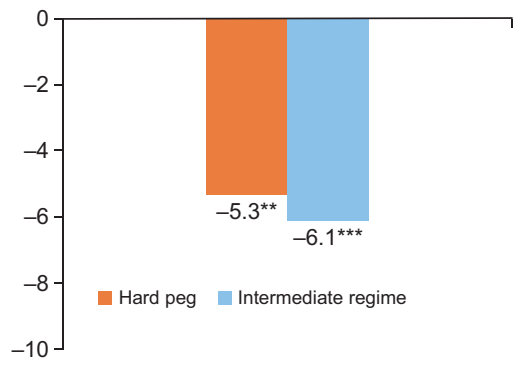

b. Baseline with Asia and Pacific Dummies

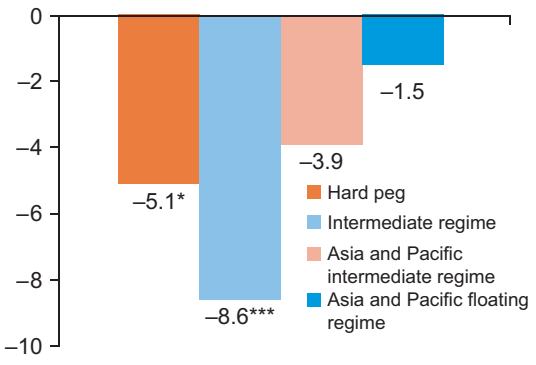

Figure 9.5 Inflation Performance across Regimes (Percent)

Source: Authors' calculations.

Note: ${ }^{*}{ }^{* *}$, and ${ }^{* * *}$ denote statistical significance at 10 percent, 5 percent, and 1 percent levels, respectively. 


\begin{tabular}{|c|c|c|c|c|c|c|c|c|c|c|}
\hline \multicolumn{11}{|l|}{ Inflation } \\
\hline \multirow[b]{2}{*}{ Hard peg } & \multicolumn{2}{|c|}{ Baseline } & \multicolumn{2}{|c|}{ Baseline with Financial Openness } & \multicolumn{2}{|c|}{ Specification } & \multicolumn{2}{|c|}{ Lagged Exchange Rate Regimes } & \multicolumn{2}{|c|}{ Excluding Small States } \\
\hline & -0.053 & -0.051 & -0.041 & -0.039 & -0.067 & -0.082 & & & -0.099 & -0.087 \\
\hline & $(-2.25)^{* *}$ & $(-1.69)^{*}$ & $(-1.85)^{*}$ & $(-1.33)$ & $(-3.10)^{* * *}$ & $(-2.37)^{* *}$ & & & $(-1.48)$ & $(-1.29)$ \\
\hline \multirow[t]{2}{*}{ Intermediate regime } & -0.061 & -0.086 & -0.054 & -0.073 & -0.143 & -0.222 & & & -0.090 & -0.094 \\
\hline & $(-3.46)^{* * *}$ & $(-2.94)^{* * *}$ & $(-3.29)^{* * *}$ & $(-2.70)^{* * *}$ & $(-4.92)^{* * *}$ & $(-3.59)^{* * *}$ & & & $(-1.71)^{*}$ & $(-1.63)$ \\
\hline \multirow[t]{2}{*}{ APD } & & -0.015 & & -0.013 & & -0.030 & & -0.031 & & -0.026 \\
\hline & & $(-0.88)$ & & $(-0.77)$ & & $(-1.21)$ & & $(-1.90)^{*}$ & & $(-0.84)$ \\
\hline \multirow{2}{*}{$\begin{array}{l}\text { APD intermediate } \\
\text { regime }\end{array}$} & & 0.062 & & 0.049 & & 0.164 & & & & 0.072 \\
\hline & & $(1.91)^{*}$ & & $(1.60)$ & & $(2.61)^{* * *}$ & & & & \\
\hline \multirow[t]{2}{*}{ Lagged inflation } & 0.612 & 0.625 & 0.610 & 0.623 & & & 0.631 & 0.650 & 0.573 & 0.591 \\
\hline & $(12.78)^{* * *}$ & $(12.04)^{* * *}$ & $(11.80)^{* * *}$ & $(10.74)^{* * *}$ & & & $(13.71)^{* * *}$ & $(12.80)^{* * *}$ & $(8.34)^{* * *}$ & $(9.11)^{* * *}$ \\
\hline \multirow[t]{2}{*}{ Money growth } & 0.009 & 0.009 & 0.009 & 0.009 & 0.034 & 0.032 & 0.008 & 0.008 & 0.009 & 0.009 \\
\hline & $(3.97)^{* * *}$ & $(3.81)^{* * *}$ & $(4.03)^{* * *}$ & $(3.87)^{* * *}$ & $(1.52)$ & $(1.44)$ & $(4.51)^{* * *}$ & $(4.22)^{* * *}$ & $(3.85)^{* * *}$ & $(3.81)^{* * *}$ \\
\hline \multirow[t]{2}{*}{ Real GDP growth } & -0.183 & -0.191 & -0.135 & -0.142 & -0.196 & -0.285 & -0.181 & -0.193 & -0.225 & -0.223 \\
\hline & $(-2.74)^{* * *}$ & $(-2.71)^{* * *}$ & $(-2.15)^{* *}$ & $(-2.15)^{* *}$ & $(-1.60)$ & $(-1.91)^{*}$ & $(-2.74)^{* * *}$ & $(-2.78)^{* * *}$ & $(-2.66)^{* * *}$ & $(-2.67)^{* * *}$ \\
\hline \multirow[t]{2}{*}{ Trade openness } & 0.008 & 0.007 & 0.012 & 0.012 & 0.010 & 0.008 & 0.008 & 0.010 & 0.011 & 0.016 \\
\hline & $(1.33)$ & $(1.12)$ & $(1.97)^{* *}$ & $(1.61)$ & $(1.14)$ & $(0.66)$ & $(1.40)$ & $(1.40)$ & $(1.34)$ & $(2.02)^{* *}$ \\
\hline \multirow[t]{2}{*}{ Financial openness } & & & -0.005 & -0.005 & & & & & & \\
\hline & & & $(-2.33)^{* *}$ & $(-1.85)^{*}$ & & & & & & \\
\hline \multirow[t]{2}{*}{ Government balance } & & & & & -0.359 & -0.376 & & & & \\
\hline & & & & & $(-3.27)^{* * *}$ & $(-2.83)^{* * *}$ & & & & \\
\hline \multirow[t]{2}{*}{ Terms-of-trade growth } & & & & & 0.050 & 0.055 & & & & \\
\hline & & & & & $(1.83)^{*}$ & $(2.04)^{* *}$ & & & & \\
\hline \multirow[t]{2}{*}{ Lagged hard peg } & & & & & & & -0.043 & -0.042 & & \\
\hline & & & & & & & $(-1.96)^{*}$ & $(-1.42)$ & & \\
\hline \multirow{2}{*}{$\begin{array}{l}\text { Lagged intermediate } \\
\text { regime }\end{array}$} & & & & & & & -0.049 & -0.083 & & \\
\hline & & & & & & & $(-2.85)^{* * *}$ & $(-2.81)^{* * *}$ & & \\
\hline \multirow{2}{*}{$\begin{array}{l}\text { APD lagged } \\
\text { intermediate regime }\end{array}$} & & & & & & & & 0.090 & & \\
\hline & & & & & & & & $(2.73)^{* * *}$ & & \\
\hline Observations & 1133 & 1133 & 1106 & 1106 & 653 & 653 & 1082 & 1082 & 942 & 942 \\
\hline$R$-squared & 0.72 & 0.70 & 0.71 & 0.69 & 0.08 & & 0.72 & 0.70 & 0.68 & 0.69 \\
\hline
\end{tabular}

Source: Authors' calculations.

Note: APD $=$ a dummy variable for frontier and developing Asia. $T$-statistics in parentheses. Asterisks denote statistical significance at 10 percent $\left(^{*}\right), 5$ percent $\left(^{* *}\right)$, and 1 percent $\left({ }^{* *}\right)$ levels, respectively. 
Ghosh Ostry, and Tsangarides (2010). The other determinants in our regression have the expected coefficients and signs, except for trade openness (Table 9.3). Lagged inflation significantly and positively affects current inflation. Money growth has a small, but positive effect, whereas higher real GDP growth leads to lower inflation.

We perform four robustness checks. First, we include an indicator for financial openness. ${ }^{8}$ The coefficients on the exchange rate regime are slightly smaller, but still significant except the coefficient on hard pegs in the regression including the $A P D$ dummy. Financial openness itself has a significant negative, but small (0.5 percent), impact on inflation.

Second, we conduct the regression using the determinants as specified in Ghosh, Gulde, and Wolf (2003) and Rogoff and others (2004). ${ }^{9}$ This specification gives higher coefficients for the exchange rate regimes, but intermediate regimes are still associated with a better inflation outcome compared with hard pegs. Third, the results are also robust to using two-year lagged exchange rate regimes, in which case the coefficients are slightly smaller, but still significant. Last, excluding small states (defined as countries with a population less than 1 million) has some impact on the results compared with the baseline regression. The coefficients are somewhat higher, but only intermediate regimes have a significant coefficient in this setup.

Next, the result for economic growth shows that only hard peg regimes seem to have a significant impact on the growth performance relative to the "floaters" (Table 9.4; Figure 9.6). Specifically, the baseline regression shows that hard pegs are associated with significant lower growth compared with floating regimes (3.2 percent). Intermediate regimes, on the other hand, have a positive, but not statistically significant, coefficient. Similarly, there is no significant difference between Asian frontier economies compared with other regions' floating regimes in terms of growth performance. Our results compare well with those of Rogoff and others (2004), who do not find a statistically significant impact of exchange rate regimes on growth for developing economies-although their results also suggest that growth declines with increased exchange rate flexibility. The results of Ghosh, Gulde, and Wolf (2003) suggest that pegged regimes are associated with higher growth for lower-income countries; however, they use de jure exchange rate measures. Ghosh, Ostry, and Tsangarides (2010), on the other hand, also find some evidence of slower growth under pegged exchange rate regimes.

The results for economic growth are robust to including the financial openness indicator, using lagged exchange rate regimes, or excluding small states. Using the specification of Ghosh, Gulde, and Wolf (2003) and Rogoff and others (2004) shows that exchange rate regimes do not seem to have any impact on growth

\footnotetext{
${ }^{8}$ For the financial openness indicator we use the financial openness measure from Chinn and Ito (2008). ${ }^{9}$ Determinants beside the exchange rate regime dummies include money growth, real GDP growth, trade openness, the government balance, and terms-of-trade shocks.
} 
Real GDP Per Capita Growth

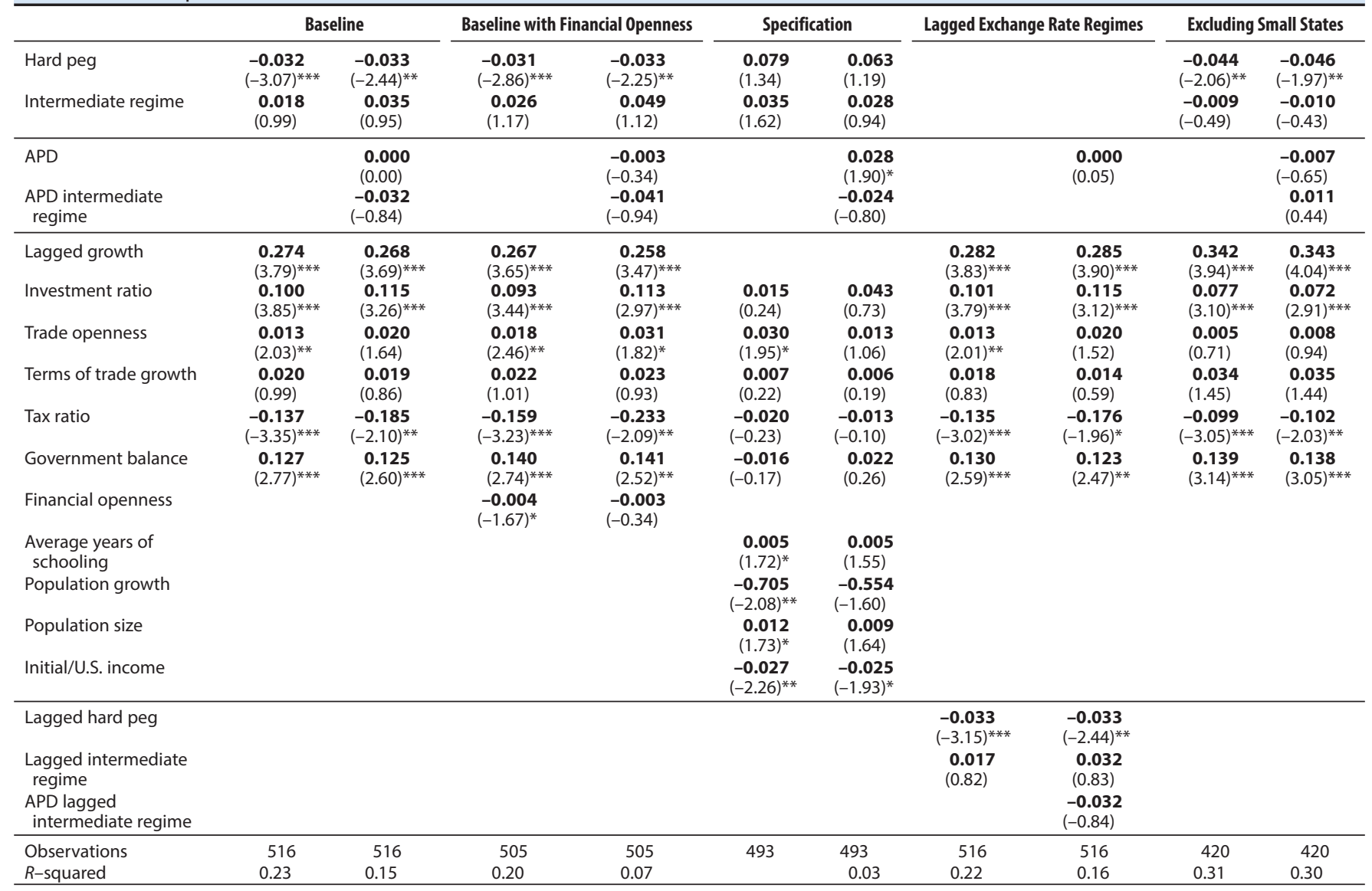

Source: Authors' calculations.

Note: $\mathrm{APD}=$ a dummy variable for frontier and developing Asia. $T$-statistics in parentheses. Asterisks denote statistical significance at 10 percent $(*), 5$ percent $(* *)$, and 1 percent $(* * *)$ levels, respectively. 

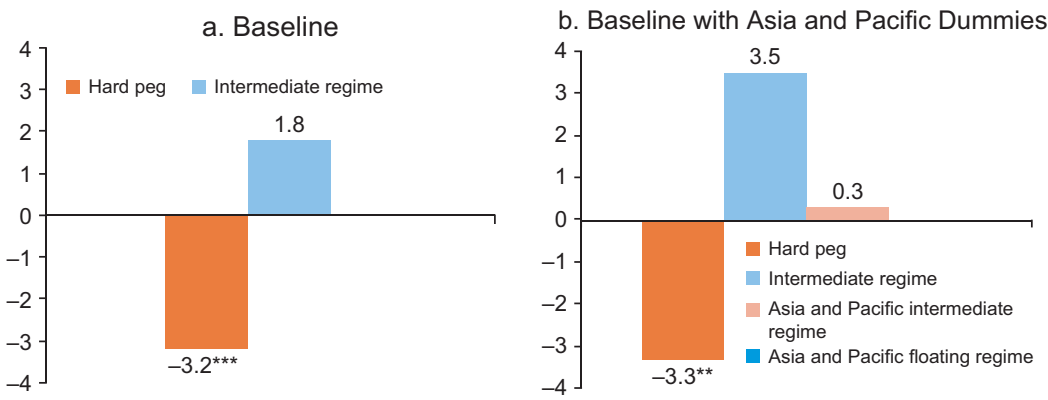

Figure 9.6 Growth Performance across Regimes (Percent)

Source: Authors' calculations.

Note: ${ }^{* *}$ and ${ }^{* * *}$ denote statistical significance at the 5 percent and 1 percent levels, respectively.

performance because all coefficients are statistically insignificant and the coefficient on hard pegs becomes positive. ${ }^{10}$ However, this regression also has a low explanatory power.

Exchange rate regime choices appear to be of some relevance to explaining differences in output volatility (Table 9.5; Figure 9.7). Hard peg regimes are associated with a statistically higher output volatility compared with floating regimes; however, output volatility is only about 1 percent higher. For intermediate regimes the effect is even smaller and not significant. Similarly, output volatility in frontier and developing Asian economies with intermediate regimes is not significantly different compared with floating regimes in other countries, but floating regimes in Asian frontier economies are associated with somewhat higher output volatility $(0.7$ percent $)$ compared with floating regimes in other regions.

The results for output volatility are robust to other specifications, except the exclusion of small states. The coefficient on hard peg regimes is only significant if the $A P D$ dummies are included. The effect of exchange rate regimes on output volatility may be driven in part by these small states, because all exchange rate coefficients become statistically insignificant when these countries are excluded from the sample.

To summarize, hard pegs are generally associated with lower inflation, lower growth, and higher growth volatility compared with floating regimes. Intermediate regimes are associated with better inflation performance-even better than hard pegs_-but growth and growth volatility are not statistically significantly different from floating regimes. The impact of exchange rate regimes in frontier and developing Asia on inflation, growth, and growth volatility does not seem to differ from that in other regions.

\footnotetext{
${ }^{10}$ The determinants include the investment ratio, trade openness, terms-of-trade shocks, the tax ratio, the government balance, years of schooling, population growth, population size, and initial income compared with U.S. income.
} 


\begin{tabular}{|c|c|c|c|c|c|c|c|c|c|c|}
\hline \multicolumn{11}{|l|}{ Real GDP Growth Volatility } \\
\hline \multirow[b]{2}{*}{ Hard peg } & \multicolumn{2}{|c|}{ Baseline } & \multicolumn{2}{|c|}{ Baseline with Financial Openness } & \multicolumn{2}{|c|}{ Specification } & \multicolumn{2}{|c|}{ Lagged Exchange Rate Regimes } & \multicolumn{2}{|c|}{ Excluding Small States } \\
\hline & $\begin{array}{r}\mathbf{0 . 0 0 9} \\
(1.86)^{*}\end{array}$ & $\begin{array}{c}\mathbf{0 . 0 1 2} \\
(2.04)^{* *}\end{array}$ & $\begin{array}{c}\mathbf{0 . 0 0 9} \\
(1.98)^{* *}\end{array}$ & $\begin{array}{c}\mathbf{0 . 0 1 1} \\
(2.04)^{* *}\end{array}$ & $\begin{array}{l}\mathbf{0 . 0 3 8} \\
(2.66)^{* * *}\end{array}$ & $\begin{array}{c}\mathbf{0 . 0 5 5} \\
(2.13)^{* *}\end{array}$ & & & $\begin{array}{l}\mathbf{0 . 0 0 9} \\
(0.77)\end{array}$ & $\begin{array}{l}\mathbf{0 . 0 1 2} \\
(0.87)\end{array}$ \\
\hline Intermediate regime & $\begin{array}{l}\mathbf{0 . 0 0 6} \\
(0.70)\end{array}$ & $\begin{array}{l}\mathbf{0 . 0 0 2} \\
(0.11)\end{array}$ & $\begin{array}{c}\mathbf{0 . 0 0 4} \\
(0.40)\end{array}$ & $\begin{array}{l}-0.002 \\
(-0.10)\end{array}$ & $\begin{array}{l}\mathbf{0 . 0 1 4} \\
(1.31)\end{array}$ & $\begin{array}{l}\mathbf{0 . 0 0 6} \\
(0.22)\end{array}$ & & & $\begin{array}{l}\mathbf{0 . 0 0 3} \\
(0.37)\end{array}$ & $\begin{array}{l}\mathbf{0 . 0 0 3} \\
(0.26)\end{array}$ \\
\hline APD & & $\begin{array}{c}\mathbf{0 . 0 0 7} \\
(2.04)^{* *}\end{array}$ & & $\begin{array}{c}\mathbf{0 . 0 0 7} \\
(1.81)^{*}\end{array}$ & & $\begin{array}{c}\mathbf{0 . 0 2 0} \\
(2.31)^{* *}\end{array}$ & & $\begin{array}{c}\mathbf{0 . 0 0 7} \\
(1.86)^{*}\end{array}$ & & $\begin{array}{l}\mathbf{0 . 0 0 6} \\
(1.22)\end{array}$ \\
\hline APD intermediate regime & & $\begin{array}{l}-0.001 \\
(-0.07)\end{array}$ & & $\begin{array}{l}\mathbf{0 . 0 0 2} \\
(0.09)\end{array}$ & & $\begin{array}{l}-0.007 \\
(-0.32)\end{array}$ & & & & $\begin{array}{l}-0.006 \\
(-0.47)\end{array}$ \\
\hline Lagged growth volatility & $\begin{array}{c}\mathbf{0 . 6 0 1} \\
(8.14)^{* * *}\end{array}$ & $\begin{array}{c}\mathbf{0 . 5 9 7} \\
(7.97)^{* * *}\end{array}$ & $\begin{array}{l}\mathbf{0 . 6 0 7} \\
(8.27)^{* * *}\end{array}$ & $\begin{array}{c}\mathbf{0 . 6 0 4} \\
(8.16)^{* * *}\end{array}$ & & & $\begin{array}{c}\mathbf{0 . 6 0 4} \\
(8.08)^{* * * *}\end{array}$ & $\begin{array}{l}\mathbf{0 . 5 9 8} \\
(7.85)^{* * *}\end{array}$ & $\begin{array}{l}0.571 \\
(6.48)^{* * *}\end{array}$ & $\begin{array}{c}\mathbf{0 . 5 6 7} \\
(6.37)^{* * * *}\end{array}$ \\
\hline Investment ratio volume & $\begin{array}{c}0.199 \\
(3.27)^{* * *}\end{array}$ & $\begin{array}{c}0.211 \\
(3.49)^{* * *}\end{array}$ & $\begin{array}{l}0.201 \\
(3.27)^{* * *}\end{array}$ & $\begin{array}{c}0.218 \\
(3.47)^{* * *}\end{array}$ & $\begin{array}{l}0.304 \\
(4.09)^{* * *}\end{array}$ & $\begin{array}{l}\mathbf{0 . 3 1 1} \\
(3.94)^{* * *}\end{array}$ & $\begin{array}{c}0.203 \\
(3.28)^{* * *}\end{array}$ & $\begin{array}{l}\mathbf{0 . 2 1 2} \\
(3.37)^{* * *}\end{array}$ & $\begin{array}{l}\mathbf{0 . 1 8 0} \\
(2.33)^{* *}\end{array}$ & $\begin{array}{c}0.193 \\
(2.58)^{* * *}\end{array}$ \\
\hline Trade openness & $\begin{array}{l}\mathbf{0 . 0 0 1} \\
(0.43)\end{array}$ & $\begin{array}{l}-\mathbf{0 . 0 0 3} \\
(-0.52)\end{array}$ & $\begin{array}{l}\mathbf{0 . 0 0 0} \\
(0.10)\end{array}$ & $\begin{array}{l}-\mathbf{0 . 0 0 6} \\
(-0.62)\end{array}$ & $\begin{array}{l}\mathbf{0 . 0 0 6} \\
(1.48)\end{array}$ & $\begin{array}{l}-\mathbf{0 . 0 0 6} \\
(-0.48)\end{array}$ & $\begin{array}{l}\mathbf{0 . 0 0 1} \\
(0.43)\end{array}$ & $\begin{array}{l}-\mathbf{0 . 0 0 3} \\
(-0.50)\end{array}$ & $\begin{array}{l}\mathbf{0 . 0 0 0} \\
(0.10)\end{array}$ & $\begin{array}{l}-0.003 \\
(-0.86)\end{array}$ \\
\hline Terms of trade growth volume & $\begin{array}{l}-\mathbf{0 . 0 0 4} \\
(-0.58)\end{array}$ & $\begin{array}{l}-\mathbf{0 . 0 0 7} \\
(-1.00)\end{array}$ & $\begin{array}{l}-\mathbf{0 . 0 0 5} \\
(-0.63)\end{array}$ & $\begin{array}{l}-0.007 \\
(-1.02)\end{array}$ & $\begin{array}{l}-\mathbf{0 . 0 1 5} \\
(-0.91)\end{array}$ & $\begin{array}{l}-\mathbf{0 . 0 2 9} \\
(-1.23)\end{array}$ & $\begin{array}{l}-\mathbf{0 . 0 0 4} \\
(-0.59)\end{array}$ & $\begin{array}{l}-\mathbf{0 . 0 0 7} \\
(-0.99)\end{array}$ & $\begin{array}{l}-0.001 \\
(-0.13)\end{array}$ & $\begin{array}{l}-\mathbf{0 . 0 0 4} \\
(-0.35)\end{array}$ \\
\hline Tax ratio & $\begin{array}{l}-0.012 \\
(-0.68)\end{array}$ & $\begin{array}{l}\mathbf{0 . 0 0 6} \\
(0.14)\end{array}$ & $\begin{array}{l}-\mathbf{0 . 0 1 1} \\
(-0.53)\end{array}$ & $\begin{array}{l}\mathbf{0 . 0 1 4} \\
(0.27)\end{array}$ & $\begin{array}{c}\mathbf{0 . 0 1 1} \\
(0.36)\end{array}$ & $\begin{array}{c}\mathbf{0 . 0 6 9} \\
(0.78)\end{array}$ & $\begin{array}{l}-\mathbf{0 . 0 1 1} \\
(-0.59)\end{array}$ & $\begin{array}{l}\mathbf{0 . 0 0 5} \\
(0.14)\end{array}$ & $\begin{array}{l}-0.003 \\
(-0.19)\end{array}$ & $\begin{array}{c}\mathbf{0 . 0 0 6} \\
(0.25)\end{array}$ \\
\hline Government balance & $\begin{array}{l}-\mathbf{0 . 0 3 0} \\
(-1.30)\end{array}$ & $\begin{array}{l}-\mathbf{0 . 0 3 5} \\
(-1.40)\end{array}$ & $\begin{array}{l}-\mathbf{0 . 0 3 0} \\
(-1.22)\end{array}$ & $\begin{array}{l}-\mathbf{0 . 0 3 6} \\
(-1.31)\end{array}$ & $\begin{array}{l}-\mathbf{0 . 1 0 1} \\
(-2.26)^{* *}\end{array}$ & $\begin{array}{l}-0.122 \\
(-1.94)^{*}\end{array}$ & $\begin{array}{l}-\mathbf{0 . 0 2 8} \\
(-1.06)\end{array}$ & $\begin{array}{l}-\mathbf{0 . 0 3 4} \\
(-1.29)\end{array}$ & $\begin{array}{l}-\mathbf{0 . 0 2 7} \\
(-0.99)\end{array}$ & $\begin{array}{l}-\mathbf{0 . 0 2 8} \\
(-0.99)\end{array}$ \\
\hline Financial openness & & & $\begin{array}{c}\mathbf{0 . 0 0 1} \\
(0.85)\end{array}$ & $\begin{array}{r}\mathbf{0 . 0 0 7} \\
(1.81)^{*}\end{array}$ & & & & & & \\
\hline Average years of schooling & & & & & $\begin{array}{l}\mathbf{0 . 0 0 1} \\
(0.64)\end{array}$ & $\begin{array}{l}\mathbf{0 . 0 0 2} \\
(0.94)\end{array}$ & & & & \\
\hline Population growth & & & & & $\begin{array}{c}0.278 \\
(1.84)^{*}\end{array}$ & $\begin{array}{r}\mathbf{0 . 4 3 0} \\
(1.80)^{*}\end{array}$ & & & & \\
\hline Initial/U.S. income & & & & & $\begin{array}{r}-0.009 \\
(-1.70)^{*} \\
\end{array}$ & $\begin{array}{l}-0.015 \\
(-1.41) \\
\end{array}$ & & & & \\
\hline Lagged hard peg & & & & & & & $\begin{array}{l}\mathbf{0 . 0 0 8} \\
(1.63)\end{array}$ & $\begin{array}{c}\mathbf{0 . 0 1 1} \\
(1.80)^{*}\end{array}$ & & \\
\hline Lagged intermediate regime & & & & & & & $\begin{array}{l}\mathbf{0 . 0 0 6} \\
(0.59)\end{array}$ & $\begin{array}{l}\mathbf{0 . 0 0 2} \\
(0.11)\end{array}$ & & \\
\hline $\begin{array}{l}\text { APD lagged intermediate } \\
\text { regime }\end{array}$ & & & & & & & & $\begin{array}{l}-0.001 \\
(-0.04)\end{array}$ & & \\
\hline Observations & 518 & 518 & 507 & 507 & 495 & 495 & 518 & 518 & 422 & 422 \\
\hline$R$-squared & 0.55 & 0.55 & 0.56 & 0.54 & 0.00 & & 0.56 & 0.55 & 0.52 & 0.51 \\
\hline
\end{tabular}

Source: Authors' calculations.

Note: APD = a dummy variable for frontier and developing Asia. $T$-statistics in parentheses. Asterisks denote statistical significance at 10 percent $(*), 5$ percent $(* *)$, and 1 percent $(* * *)$ levels, respectively.

\section{CInternational Monetary Fund. Not for Redistribution}



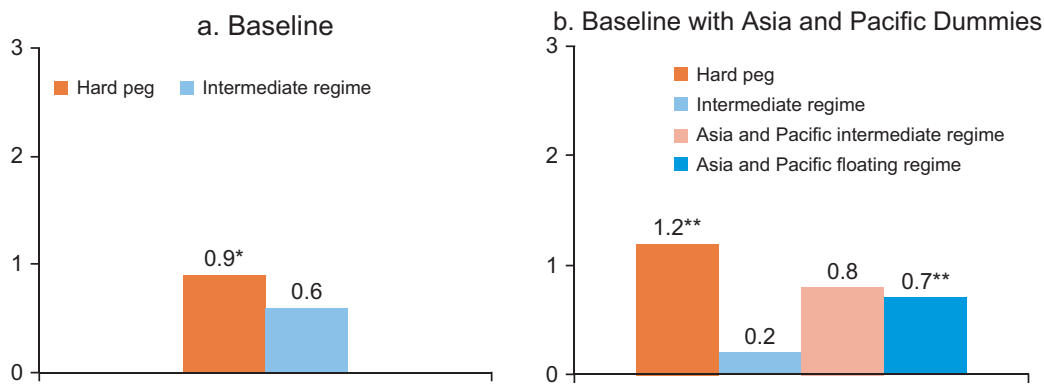

Figure 9.7 Growth Volatility Performance across Regimes (Percent)

Source: Authors' calculations.

Note: * and ${ }^{* *}$ denote statistical significance at 10 percent and 5 percent levels, respectively.

\section{CONCLUSION}

In this chapter, we set out to explore how monetary policy is conducted across frontier and developing Asia and assess the extent to which the monetary and exchange rate regime choice a low-income country makes can influence growth and inflation outcomes. We find that frontier and developing Asia's institutional frameworks for monetary policy remain rudimentary and that there is a general lack of operational autonomy for central banks, which helps explain the gravitation toward exchange rate targeting as a regime choice. ${ }^{11}$ The primary concern for growth over price stability and the desire for monetary policy flexibility have also led the majority of these countries to adopt a variant of intermediate exchange rate regimes with limited degrees of financial openness.

Through a set of multinomial logit regressions and robustness checks, we assessed how different exchange rate regimes impact economic performance with a focus on price stability and growth. We found that intermediate regimes appear to be the most conducive for achieving price stability both when compared across low-income countries in general and within the frontier and developing Asia subgroup during the initial period of growth takeoffs. Moreover, the intermediate regimes' ability to ensure lower inflation has not come with a sacrifice of growth and growth volatility over time.

\footnotetext{
${ }^{11} \mathrm{~A}$ table that shows the main provisions of central bank legislation as they relate to monetary policy frameworks for the frontier and developing Asian economies in this chapter is available from the authors on request by sending an email to FrontierAsiaAuthors@imf.org.
} 


\section{APPENDIX 1}

TABLE A9.1

\begin{tabular}{|c|c|c|}
\hline \multicolumn{3}{|c|}{ Data and Definitions } \\
\hline Variable & Description & Source \\
\hline Inflation & Scaled consumer price inflation $(p /(1+p))$ & WEO \\
\hline $\begin{array}{l}\text { Real GDP per capita } \\
\text { growth }\end{array}$ & Real GDP per capita growth & WEO \\
\hline $\begin{array}{l}\text { Real GDP growth } \\
\text { volatility }\end{array}$ & Three-year centered standard deviation of real GDP growth & WEO \\
\hline Relative size & Ratio of country's GDP over U.S. GDP & WEO \\
\hline Geographical area & Land area (sq. km) & WDI \\
\hline $\begin{array}{l}\text { International reserves } \\
\text { to imports ratio }\end{array}$ & International reserves in months of imports & WEO \\
\hline $\begin{array}{l}\text { Ratio of quasi-money } \\
\text { to money }\end{array}$ & Ratio of quasi-money to money & IFS \\
\hline Trade openness & Sum of exports and imports of goods and services (percent of GDP) & WEO \\
\hline Landlocked country & Dummy equal to 1 if a country is landlocked & \\
\hline Island & Dummy equal to 1 if a country is an island & \\
\hline Money growth & Broad money growth & WEO \\
\hline Real GDP growth & Real GDP growth & WEO \\
\hline Investment ratio & Gross fixed investment (percent of GDP) & WEO \\
\hline Terms-of-trade growth & Terms-of-trade growth & WEO \\
\hline Government balance & General government balance (percent of GDP) & WEO \\
\hline Tax ratio & General government revenue (percent of GDP) & WEO \\
\hline Financial openness & Financial openness & $\begin{array}{r}\text { Chinn and } \\
\text { Ito (2008) }\end{array}$ \\
\hline $\begin{array}{l}\text { Average years of } \\
\text { schooling }\end{array}$ & Expected years of schooling & WDI \\
\hline Population growth & Population growth & WEO \\
\hline Population size & Log of total population & WEO \\
\hline Initial/U.S. income & Log of ratio of per capita GDP to U.S. per capita GDP in 1990 & WEO \\
\hline Exchange rate regime & $\begin{array}{l}\text { Hard peg includes exchange arrangement with no separate legal } \\
\text { tender and currency board arrangement; intermediate regime } \\
\text { includes conventional peg to a single currency, conventional peg to } \\
\text { a composite, pegged exchange rate within horizontal bands, } \\
\text { crawling peg and crawling band; floating regime includes managed } \\
\text { floating with no predetermined path for the exchange rate and } \\
\text { independently floating; based on methodology before } 2008 \text {. }\end{array}$ & AREAER \\
\hline
\end{tabular}

Source: Authors' compilation.

Note: AREAER = IMF, Annual Report on Exchange Arrangements and Exchange Reserves; IFS = IMF, International Finance

Statistics database; WDI = World Bank, World Development Indicators; WEO = IMF, World Economic Outlook database.

\section{CInternational Monetary Fund. Not for Redistribution}


TABLE A9.2

\begin{tabular}{llll}
\hline List of Countries & & & \\
\hline Afghanistan & Djibouti & Madagascar & Solomon Islands \\
Albania & Dominica & Malawi & Somalia \\
Angola & Eritrea & Maldives & Sri Lanka \\
Armenia & Ethiopia & Mali & St. Lucia \\
Azerbaijan & Gambia, The & Mauritania & St. Vincent and the Grenadines \\
Bangladesh & Georgia & Moldova & Sudan \\
Benin & Ghana & Mongolia & Tajikistan \\
Bhutan & Grenada & Mozambique & Tanzania \\
Bolivia & Guinea & Myanmar & Timor-Leste \\
Burkina Faso & Guinea-Bissau & Nepal & Togo \\
Burundi & Guyana & Nicaragua & Tonga \\
Cambodia & Haiti & Niger & Uganda \\
Cameroon & Honduras & Nigeria & Uzbekistan \\
Cape Verde & India & Pakistan & Vanuatu \\
Central African Republic & Kenya & Papua New Guinea & Vietnam \\
Chad & Kiribati & Rwanda & Yemen \\
Comoros & Kyrgyz Republic & Samoa & Zambia \\
Congo, Dem. Rep. & Lao P.D.R. & São Tomé and Príncipe \\
Congo, Rep. & Lesotho & Senegal & Zimbabwe \\
Cote d'Ivoire & Liberia & Sierra Leone & \\
\hline
\end{tabular}

Note: The sample includes all countries on the Poverty Reduction Growth Trust (PRGT) list as of 2008.

\section{REFERENCES}

Ahuja, A., N. Duma, and N. Ha. 2013. "Toward a More Robust Monetary Policy Framework in Vietnam.” Unpublished. International Monetary Fund, Washington.

Aizenman, J., M. D. Chinn, and H. Ito. 2008. "Assessing the Emerging Global Financial Architecture: Measuring the Trilemma's Configurations over Time.” NBER Working Paper 14533, National Bureau of Economic Research, Cambridge, Massachusetts.

Anderson, H. 2009. “Exchange Policies Before Widespread Floating (1945-1989).” Unpublished.

Bailliu, J., R. Lafrance, and J. Perrault. 2003. "Does Exchange Rate Policy Matter for Growth?” International Finance 6 (3): 381-414.

Bleaney, M., and M. Francisco. 2007. "Exchange Rate Regimes, Inflation and Growth in Developing Countries_An Assessment." B.E. Journal of Macroeconomics 7 (1): Article 18. http://ww.bepress.com/bejm/vol7/iss1/art18.

Bubula, A., and I. Ötker-Robe. 2002. "The Evolution of Exchange Rate Regimes Since 1990: Evidence from De Facto Policies," IMF Working Paper 02/155, International Monetary Fund, Washington.

Calderon, C., and K. Schmidt-Hebbel. 2003. "Macroeconomic Policies and Performance in Latin America." Journal of International Money and Finance 22 (7): 895-923.

Chinn, M. D., and H. Ito. 2008. "A New Measure of Financial Openness." Journal of Comparative Policy Analysis 10 (3): 309-22.

Courdert, V., and M. Dubert. 2005. "Does Exchange Rate Regime Explain Differences in Economic Results for Asian Countries?” Journal of Asian Economics 16 (5): 874-95.

Frankel, J. 2010. "Monetary Policy in Emerging Markets: A Survey." NBER Working Paper 16125, National Bureau of Economic Research, Cambridge, Massachusetts.

Ghosh, A., A. Gulde, and H. C. Wolf. 2003. Exchange Rate Regimes: Choices and Consequences. Cambridge, Massachusetts: MIT Press.

\section{CInternational Monetary Fund. Not for Redistribution}


Ghosh, A., J. Ostry, and C. Tsangarides. 2010. Exchange Rate Regimes and the Stability of the International Monetary System. IMF Occasional Paper 270. Washington: International Monetary Fund.

Harms, P., and M. Kretschmann. 2009. "Words, Deeds and Outcome: A Survey on the Growth Effects of Exchange Rate Regimes." Journal of Economic Surveys 23 (1): 139-64.

International Monetary Fund (IMF). 2013. "Staff Report for the 2013 Article IV Consultation, Mongolia." Washington.

Juhn, G., and P. Mauro. 2002. "Long-Run Determinants of Exchange Rate Regimes: A Simple Sensitivity Analysis.” IMF Working Paper 02/104, International Monetary Fund, Washington.

Levy-Yeyati, E., and F. Sturzenegger. 2001. "Exchange Rate Regimes and Economic Performance." IMF Staff Papers 47 (Special Issue). Washington: International Monetary Fund.

2003. "To Float or To Fix: Evidence on the Impact of Exchange Rate Regimes on Growth." American Economic Review 93 (4): 1173-93.

Petreski, M. 2009. "Analysis of Exchange-Rate Regime Effect on Growth: Theoretical Channels and Empirical Evidence with Panel Data." Economics Discussion Papers, No. 2009-49, Kiel Institute for the World Economy, Kiel, Germany. http://economics-ejournal.org/economics /discussionpapers/2009-49.

Poirson, H. 2001. "How Do Countries Choose Their Exchange Rate Regime?” IMF Working Paper 01/46, International Monetary Fund, Washington.

Reinhart, C., and K. Rogoff. 2004. "The Modern History of Exchange Rate Arrangements: A Reinterpretation." Quarterly Journal of Economics 119 (1): 1-48.

Rogoff, K., A. Husain, A. Mody, R. Brooks, and N. Oomes. 2004. Evolution and Performance of Exchange Rate Regimes. IMF Occasional Paper 229. Washington: International Monetary Fund. 
Page numbers followed by $b$ refer to boxes, $f$ to figures, $n$ to notes, and $t$ to tables.

A

Accountability, central bank, 231

Afghanistan, 86

Africa

debt overhang, 99, 99n

frontier economies of, 3

governance, 91-92

growth slowdowns in, 6, 81, 85-86, 100,103

income inequality in, 114

risk of growth slowdowns in, 101, 102-104

trade patterns, 65, 65f, 66, 66f, 68

Angola, 70

Argentina, 36, 41-42, 211

currency board, 16, 17b

Asian financial crisis

cause of, 16

investment patterns and, 97

lessons for developing economies from, 165

lessons for exchange rate policies from, 16-18

lessons for financial regulation from, 31-32

Association of Southeast Asia Nations, $114,178-179 b$

B

Bangladesh

bond market, 221

diversification experience in, 76-77, $77 f$

Eurobonds, $5 b$

financial sector of, 8, 166, 168

foreign bank entry in, $196 t$

future prospects, 132-133b

growth, $130 b$

inclusive growth in, 130-133b

income in, 70

income inequality in, $125,132 b$ monetary policy, 227, 229

output quality, 69

poverty and, $131 f, 132 f$

poverty reduction in, $130 b$

remittances to, $130 b$

social spending programs, $131-132 b$

status of women in, $131 b$

stock market capitalization, 158

See also Frontier economies

Banking sector

asset structure, $167 f, 168 f$

capital adequacy requirements, 34,

176-177, 182

concentration of assets in, 166

concentration of credit risk in, 148, 180

foreign bank entry in frontier and developing Asia, 168-169, 186,

$187 b, 194-199 t, 200$

government bank holdings, 44

interbank linkages, 181

liquidity management, 147

performance, 173-177

restructuring and resolution systems,

183, 191

See also Financial sector

Basel Committee, 200, 200n

Bhutan

financial sector of, 158, 180

foreign bank entry in, $196 t$

monetary policy, 227, 229

real estate boom, $189 b$

Bond markets, $161 n$

foreign investment in, 183, 205, $217-$ $219,219 f$

in frontier and developing Asia, 152,

153f, 163, 203, 214, 216f, 217t, $218 f$

growth, 203

indexes, 205-206, $207 t$

prospects, 221-222

risk-return profiles, $217 t$ 
Brazil, $45 n$

fiscal rules, 37, 43

inclusive growth in, $122,122 f$

public transfers, 41-42, 125

social insurance in, 125

Bubbles and booms

financial liberalization and risk of, 27 as negative outcome of growth, 97

Buddhism, 99

Burundi, 85-86, 101

C

Cambodia

financial sector of, $8,147 n, 166,168$, 169, 182, 191

foreign bank entry in, 187b, $196 t$

growth rate, $81,82 f$

income inequality in, 114,125

monetary policy, 228, 228f, 229

poverty reduction in, 114

real estate boom, $189 b$

risk of growth slowdown in, 83

See also Frontier economies

Capital flows

in course of Asian financial crisis, 16

evolution of emerging economy monetary policies in 1990s, 13-16

financial sector deepening to reduce risk from volatility in, 145-146

foreign bank presence in Asia,

168-169

potential risks for frontier markets, 8-9

process of liberalization, 27-29, $29 f$

protections for developing economies in

Bretton Woods era, 13

risks in bond market growth, 222

structural factors mediating growth

effects of, 25, 26-27

Cell phone mobile bill payment, 6,129 , 155, 161-162

Central bank accountability and transparency, 231 autonomy, 19-20, 228-229

lending to government, 228-229

in monetary policy implementation, 229

protecting independence of, 19-20

Chile, 6, 36, 366, 41-42
China

foreign bank entry in, 187b, $195 t$

income inequality in, 122

lessons from capital flow liberalization, $27-28$

nonbank financial sector, 33-34

output quality, 69

Civil conflict, 89.90, 99-100, 100t

Competitiveness

current account deficits and, 18

exchange rate and, 15, 16, 17b

financial sector, 129, 186

growth and, 98

Contingent liabilities, 37-38, 42-43

Corruption, 91, 129

Côte d'Ivoire, 101

Credit, access to, 155-156, $157 f$

Credit cooperatives, 169

Credit growth, 173, 174f, 177-180, $188 b, 189 f$

Credit-to-GDP ratio, 7, 150, 157, 158-159, 177, 188b, 189b

Currency forwards, 147

Current account balances frontier market characteristics, 214 trends in emerging economies, $19 f$ vulnerability of emerging markets, 18

Cyprus, 45

D

Debt markets benefits of depth and liquidity in, 151 development rationale, 33

fiscal crisis risk, 44 obstacles to development, 32-33 private credit growth, $173,174 f$ risky lending practices, $177-180$

Deposit insurance, 32, 183

Deposit-to-GDP ratio, 7

Diversification

benefits of, 6, 59

findings from country case studies, 70-71, 76-78

growth and, 3, 59, 60-63, 61f, 62t

growth slowdown risk and, 83, 88-90, 96-97

measurement of, 59-60, 72

patterns and trends, 6, 63-66, 64f,

65f, $66 f$ 
policy reforms to support, 70-71, 78 quality upgrading and, 66-69, 68f, 71 real-sector, $66,67 f$

trade and domestic, 59-60

volatility and, $63,63 f$

\section{E}

Economic Freedom of the World, 91

Education

investment to foster inclusive growth, $123,124,124 f$ public investment in, 41

Emerging Market Bond Index, 5b, 206

Emerging markets

current account balances, 18, $19 f$

evolution of monetary policies in 1990s,

13-16

exchange rate regimes, $18,46-48$

fiscal policy challenges, 34-35

foreign bank entry in, 187b, 194-196t

frontier markets' transition to, 220-221

growth trends, $4 f$

income inequality in, $114-117,115 f$, $116 f$

lessons from, for frontier economies, 46-49, 165-166

public debt in, 39-40

tax policy and collections in, 39, 40-41

terminology and classification, 204-205, 205t

trilemma framework for analyzing monetary policies of, 13-16, $14 f$

Energy infrastructure, 93

Energy subsidies, 41, $42 f$

Equity markets, $152,161 n, 203$, 206-210, 210t, 211f, 214, 215, 217-218f, $219 f$

Eurobonds, $5 b$

European Central Bank, 21

Exchange rate regime(s)

challenges for growth in frontier economies, 8,13

classification of low-income countries by, $232 t$

country characteristics and choice of, $15-16$

effects on growth in low-income countries, 231-232, 235, 238t, 237,239 effects on output volatility in lowincome countries, 231-232, 233, $235,237,239,240 t, 241 f$

fear of floating, 14-15

financial sector development and, 29-31, 144

fiscal crisis risk, 43

in frontier and developing Asia, $144 f$, 225-228, 227f, 229

frontier bond markets and, 221

growth and, 98

with hard pegs, 16, 232t, 233, 235, 237, 239

inflation outcomes in low-income countries, 233, 235-240, 235f, $236 t, 239$

inflation targeting regime(s) and, 22 institution building and, 19-20

intermediate regimes, $8,14-15,225$, $226,232 t, 233,235,237,239$

lessons from Argentina's currency board experience, $16,17 b$

lessons from Asian financial crisis, 16-19

lessons from emerging market economies, 46-48

managed floats, 14-15, 18

policy responses to global integration trends, 13-16

reforms to reduce exposure to movements in, 42

trade-offs in choice of, 231-232

trends in developing economies,

$14-15,15 f$

trends in emerging economies, 18

See also Fixed exchange rates; Floating exchange rates

Exchange-traded funds, 220

Exports

Argentina's, $17 b$

Bangladesh's, 77, $77 f$

Chile's, $36 b$

diversification, 6, 59, 60, 63f, 64f, 66, 96-97

growth and, 95, 96-97, 97t, 98, 100-101

growth strategy based on, 18

oil, 99

primary dependence, 101, 103

quality, 66-69, 68f, 70f, 71

Vietnam's, 77, $77 f$

\section{CInternational Monetary Fund. Not for Redistribution}


F

Financial sector access, 6-7, 34, 127, 129, 155-156, 156f, 159-160, 159f, $160 n$

bank-based economies, 33, 45, 148, 166 credit growth, 173

credit information gap, 161, $162 f$ cross-border linkages, 183-186 current supervisory capacity, 169-173 data collection, 190, 192 data sources, 177 debt market development, 32-33 development of, for liberalization, 29-34 development of, growth and, 142 diversification of revenue sources, 34 effects of global financial crisis on, $185 b$ financial market functioning, 151-154, $153 f, 161,163$

foreign claims on banks of frontier and developing Asia, 178b, 179f, 183-184, $184 f$

lessons from emerging markets' experiences in Asian financial crisis, $178-179 b$

mobile phone account management technology, 6, 129, 155, 161-162

nonbank financial institutions, 33-34, 169

number of financial institutions, 166-167 profitability, 175, $175 f$

public confidence in, 32, 33, 44 public debt and vulnerability of, 44-45 public sector linkages, 44-45 reforms to foster inclusive growth, 127-129 risk identification in, 188-189b, 193t risk management policies and practices, 162-163, 181-183, 186-188

risks and vulnerabilities in frontier and developing Asia, 177-186, 191-192 sectoral lending patterns, 166, 177-180 securitization requirements, 34 structure and performance of, in frontier and developing Asia, 149f, 150-151, 166-173, 169f, 181

weaknesses of frontier economies, 7-8 See also Banking sector; Financial sector deepening; Financial sector regulation and supervision
Financial sector deepening

access and, 34

benchmarking, 156-160, $158 f$

benefits of, 7, 141-148, 163

current state of, in frontier and developing Asia, 141, 148-160, 163

defined, 141

destabilizing effects of, 158-159

exposure to macroeconomic volatility

reduced by, 142-143

growth and, 142, 163, 165

inclusive growth and, 127

macroeconomic policy effectiveness and, 143-145

macroeconomic stability to foster, 160

measurement of, $148 n$

patterns and trends in frontier economies, $7,128 f, 128 t$

potential risks in, 7

risk management and, 146-148

strategies for promoting, 160-163

vulnerabilities associated with, 165, 177

Financial sector regulation and supervision foreign bank entry rules, 200

future challenges for frontier economies, 7

human capital for, 32

in implementation of macroprudential policies, 24-25

improvements in, in frontier and developing Asia, 186-188

lessons from experiences of emerging economies in 1990s, $178 \mathrm{f}$

in liberalization process, 30, $31-32$

of nonbank financial institutions, $172 f, 191$

policies to promote growth of frontier economies, $\mathrm{v}$

to promote financial deepening, 162-163

public perception of, 33

recommendations for frontier economies, 24-25, 188, 190-191, 192

weaknesses of frontier and developing Asia, 182-183, 191-192

weakness of frontier economies, 8

Fiscal councils, 37

Fiscal dominance, 15-16, 45-46, 47b

\section{(C) International Monetary Fund. Not for Redistribution}


Fiscal policy

building credibility of, 43

challenges for emerging market economies, 34-35

countercyclical, 145, $146 f$

effectiveness of, financial sector development and, 143-145

fiscal crisis risk, 43

to foster inclusive growth, 123-126, $124 f$

goals for frontier economies, 35

lessons from experiences of emerging economies, 48

monetary policy coordination with, 46

monetary policy dominated by, 15-16, 45-46

reforms to promote and sustain growth, v, 40-43

risk identification and management, 37-38

role of fiscal institutions in

implementation of, 35-37

rule enforcement, 37

short-term and long-term objectives of, 35

speed of consolidation, 44

sustainability goals, 34

transparency, 38

Fiscal rules, 35-37, 35n, 366, 43, 48-49

Fixed exchange rate(s)

causes of collapse in, 43

economic performance under,

232-233

patterns and trends in use of, 14-15,

$15 f, 16,18,46-47,144,144 f$

trade-offs in adoption of, 231-232

in trilemma formulation, $13,14 f$,

227-228, $228 f$

Floating exchange rate(s)

bond market investment and, 221

economic performance and, 233, 235,

237,239

fear of, 14-15

patterns and trends in use of, 14-15,

$15 f, 18,232 t$

in trilemma formulation, $14 f, 227-228$, $228 f$

Food subsidies, $42 f$
Foreign direct investment, 76

capital flow liberalization process, 27-28

in frontier economies, 3-4, 5, 183

future challenges for frontier markets, 8-9

regulation, 200

Foreign exchange markets, 152, $154 f$

Frontier economies

Asian countries, 4n. See also specific country

banking sector performance in, $173-177,178 b, 179 f$

bond markets, 205-206, 207t, 214, 215-219, 217-218f, 219f, 221-222

characteristics of, v, 3

definition and characteristics of, v, 3-4, $5 b, 8,204$

east Asia, 113n, 114, 117n, 120, 122-123, 126

effects of exchange rate regimes on economic performance, 235-239

equity markets, 206-210, 210t, 211f,

214, 215, 217-218f, $219 f$

financial sector risks and vulnerabilities, 177-186

future challenges and opportunities for, v, 5, 9-10, 49, 113

growth. See Growth of frontier economies income inequality trends in, 113-114,

$115 f, 134,135$

inflation history, $11,12 f, 225,226 f$

investment opportunities in, 3-4, 203

lessons from experiences of emerging

markets for, 46-49, 165-166,

178-179b

market characteristics and performance, 210-220, 212-213t

monetary policy characteristics, 225-228, 227t

population, 4

potential risk of changes in capital flows in, 8-9

poverty reduction in, $114,115 f$

size of, 211-214

south Asia, 113n, 114-115, 120,

122-123, 126

structural characteristics of financial sector of, 166-173, $167 f$

terminology and classification, 204-205, 205t

\section{(C) International Monetary Fund. Not for Redistribution}


G

Geographic location, 96

Ghana, 81, 82f, 101, 102

Gini coefficient, 114-117, 115f, 116f, 119,135

Global financial crisis (2007-09) causes of, 24 financial sector outcomes, $185 b$ fiscal rules in mediating effects of, 37 lack of international financial linkages as buffer against, 183, 184-186, 1856 loan performance outcomes of, 175-176, $176 f$ outcomes in frontier Asia, 5

Global integration cross-border financial market linkages, 183-186

evolution of exchange rate policies in response to, 13-16

financial sector deepening to mitigate risk from, 145-146

geographic location and, 96

growth and, 25-27, $26 f$

potential risks for frontier economies, $5,9,11-12,13,27,183,184-186$, $185 b$

trends, 26f, 145-146, $147 f$

Governance

challenges for frontier economies, 11 as determinant of growth slowdown, 90-92

reforms to foster inclusive growth, 129

in resource-dependent countries, 89-90

risks in financial sector, 181

size of government, 91

Government Bond Index-Emerging Markets, 5b, 206, $209 f$

Greece, 45

Green Revolution, $130 b$

Growth of frontier economies diversification and, 59, 60-63, 61f, 62t effects of exchange rate regimes on, 231-232, 235, 237, 238t, 239

financial integration and, 25-27, $26 f$ financial system development and, 142, 163,165

fiscal reforms to sustain, 40-43

future challenges to, 6, 9, 11, 113 inflation trade-offs in monetary policy choices, 231-232

infrastructure development and, 93

poverty reduction correlated with, 120 , 135

pro-poor, 117-120, 119t, 135

prospect for, 113

public spending and, 41-42

recommendations for policy reforms to promote, $v, 9$

risks from external shocks and spillovers, $11-12,27$

sources of, 3, 203

state ownership of banks and, $170 f$ trends, $4 f, 5,11,12 f, 114,115 f, 203$, $204 f, 225,226 f$

vulnerabilities associated with, 165

See also Growth slowdowns; Inclusive growth

Growth slowdowns

banking crises and, 98, 99

defined, 82

determinants of, 82, 86, 100-101, 103

historical episodes of, 85-86, 85t, $103,105 t$

infrastructure development and, 93, $94 t$

institutional factors in, 90-92, 92t, 101

in low-income versus higher-income countries, 83,85

macroeconomic factors in, 97-99, 98t

measurement and analytical methodology, 81-82, 83, 84-88, 106-107t

patterns and trends in low-income countries, $81,82 f$ policy reforms to prevent, $82-83$ poverty traps and, 83 risk of, among low-income countries, 101-104, 102t, $103 f$ salient issues for low-income countries, 81 sectoral distribution of, 88-90

Gulf Cooperation Council, 214

H

Health care, 123, 124, $124 f$

Hedge funds, 220

Herfindahl index, 72 
Human capital

central bank, 20

for financial sector regulation, 32

governance role in development of, 129

Import structure, growth and, 98-99

Inclusive growth

causes of income inequality, 113

country case studies, 130-134b

financial reform to promote, 127-129

future challenges for frontier economies, 6-7

governance reform to promote, 129

income inequality trends, 113-114, $115 f$

international comparison, $122,122 f, 123 f$

labor market reform and, 126-127

measurement, 117-118, 120-122

patterns and trends in frontier economies, 6, 122-123, 122f, $123 f$

policies to foster, 123-129

reforms to promote, 9

significance of, in growth of frontier economies, v, 6, 113

See also Income inequality

Income

diversification and, 63-64, 64f, 66

export quality and, 67-68

growth patterns and trends, $81,82 f$

inequality. See Income inequality

labor share of, 127

poverty reduction associated with

increases in, 119

Income inequality

in Bangladesh, $132 b$

bargaining power of workers and, 126

causes of, 113, 117

financial sector development and, 142

international comparison, 114-117

patterns and trends, 113-114, 115f,

134,135

poverty rate correlated with changes in, 119

in Vietnam, 133-134b, $133 f$

See also Inclusive growth

India

capital flow regulation, 28

cash transfers in, 6

fiscal dominance in, $46,47 b$ foreign bank entry in, $187 b, 195 t$

labor market reforms, 126

output quality in, 69

Indonesia, 7, 86, 221

bank recapitalization, 38, 42-43

bond market, $5 b$

fiscal risk assessment, 38

foreign bank entry in, $187 b, 195 t$

tax policy, 41

Inflation

exchange rate policies to stabilize, 13

growth and, 97-98

growth trade-offs in monetary policy

choices, 231-232

monetary policy effects on, in lowincome countries, 232-233,

235-240, 235f, 236t, 239

risk in fiscal dominance, 45-46

trends, 11, 12f, 225, $226 f$

See also Inflation targeting

Inflation targeting

core versus headline, $22,23 b$

exchange rate management and, 13, 22

frameworks for, 20-21

lessons from experiences of emerging economies, 47-48

lessons from Korean experience, $23 b$

policy implementation challenges,

21-22

policy transmission channels, 21-22

public debt and, 21

in response to global financial crisis, 24

trends, $19,20 f$

Infrastructure

as growth factor, 93, $94 t$

investment in soft, and growth of

frontier economies, $v, 7-8,9$

Insurance markets, $154 f, 155,163$

Interest rate $(s)$

evolution of emerging economy monetary policies in 1990s, 13-16

public debt in emerging markets and, 39,40

reforms to reduce exposure to

movements in, 42

International Monetary Fund, 186

Investment

financial deepening and, 142, 165

in frontier bond markets, 205, 214, 219

\section{(C) International Monetary Fund. Not for Redistribution}


in frontier equity markets, 219-220

in frontier markets, 213, 219-220

growth and, 97

opportunities in frontier Asia, 203

risk of booms and bubbles, 97, 162

Ireland, 37

\section{J}

Japan, 69, 114

\section{K}

Korea, Republic of capital account liberalization in, 29, $30 b$ financial sector oversight, 33 fiscal policy authority, 37 foreign bank entry in, 187b, $194 t$ inflation targeting in, 22, $23 b$ output quality, 69

\section{L}

Labor market policies to foster inclusive growth, 126-127

Lao People's Democratic Republic, 86 financial sector of, 168, 180, 182 foreign bank entry in, 187b, 197t monetary policy, 227, 229 poverty reduction in, 114 private credit in, 150

Latin America, 39, 40, 115, 122, $123 n$

Legal system

bank restructuring and resolution systems, 183, 191

challenges to sustaining growth, 11

fiscal rules, 35-37, 35n, 36b

quality measurement, 91

quality of, and growth, 90-91, 92

reforms to promote financial inclusion, 129

weaknesses of financial sector in frontier and developing Asia, 182-183

Liberalization country characteristics for successful, 29 financial openness effects on growth, 91, $127-128$

financial sector development and, 29-34 growth outcomes of financial integration, 25-27

IMF principles for implementation of, $27,28 b$ lessons from experiences of emerging economies, 48

as source of growth in frontier economies, 3

timing and sequence of, 27-29, 29f, 48 trade openness effects on growth, 96

Liberia, 85-86, 90, 101, 102

Liquidity forecasting, 229

\section{M}

Macroprudential policies, 24-25

Malawi

agricultural sector, $90 n$

foreign bank entry in, $187 b$

growth rate, $81,82 f, 85-86,90$

monetary policy, 229

Malaysia

bank recapitalization, 38

bond market, 5b, 221

financial sector, 7

foreign bank entry in, $195 t$

income growth, 70

output quality, 69

Maldives

financial sector, 166, 168, 176, 183, $189 b$

foreign bank entry in, 187b, 197t

monetary policy, 228

Manufacturing sector growth slowdowns, 88

Mauritania, 81, 82f, 101, 104

Mexico, 6, 41-42, 125, 221

Middle East, 65, 114, 122, 150

Minimum wage, $126,126 f$

Mining, 88-90

Monetary policy

central bank autonomy, 19-20, 228-229

challenges for growth in frontier economies, 8

choices of frontier and developing countries, 225-228, 227t

country case study, 230-231b

cross-country comparison of economic performance of, 231-241

evolution of, in emerging economies in 1990s, 13-16

financial sector development and, 144-145 
fiscal dominance of, 15-16, 45-46

fiscal policy coordination with, 46

implementation, 229

inflation targeting, 19, $20 \mathrm{f}$

instruments of, 144-145, $145 f$

lessons from emerging market economies, 46-47

liquidity forecasting, 229

macroprudential frameworks, 24-25

objectives, 229

procyclicality, 24

reforms to promote growth of frontier economies, $\mathrm{v}$

trade-offs, 231-232

transmission of, state ownership of banks and, $171 f$

transparency, 231

See also Exchange rate regime(s)

Money markets, 152, 161, 163

Mongolia

banking sector, $147 n$

Eurobonds, $5 b$

financial sector, $8,158,166,172 f, 180$, $182,183,189 b$

foreign bank entry in, $197 t$

growth slowdown risk, 101-102, 104

monetary policy, 228, $228 f$

private credit in, 150

real estate boom, $189 b$

risk of growth slowdown in, 83

Mutual funds, 219-220

Myanmar, 5

financial sector, 181, 182

foreign bank entry in, $198 t$

monetary policy, 227

\section{$\mathbf{N}$}

Natural disasters, 82, 99-100, 100t

Nepal

financial sector, 158, 166, 168, 169, $173,176-177,183$

foreign bank entry in, $198 t$

income inequality in, 114

monetary policy, 227, 229

real estate boom, $189 b$

risk of growth slowdown in, 83

stock market, 152, 158

Newly-industrialized Asian economies,

114,122
Next Generation Emerging Market Index, $5 b, 206,208 f$

Nonbank financial institutions, 33-34, $165,169,172-173 b, 191$

Nonperforming loans, 7-8, 175-176, $176 f, 178 f, 185 b$

O

Oligopolies, 166

Organisation for Economic Co-operation and Development, 123-124

Output volatility diversification and, 63

effects of exchange rate regimes in lowincome countries on, 231-232, 235, 237, 239, 240t, $241 f$

financial sector development to reduce, 7

monetary policy cyclicality and, 24

P

Pakistan, 86

Papua New Guinea

financial sector, $8,168,169,172,180$, 181,183

foreign bank entry in, $198 t$

growth slowdown risk, 101-102, 104

monetary policy, 228, 229

risk of growth slowdown in, 83

stock market capitalization, 158

Pension systems, 125, 154f, 155, 163

Philippines

bond market, $5 b, 221$

cash transfer program, 125

foreign bank entry in, $187 b$

Population

demographic determinants of growth, 93-95, 95t

density, growth and, 94-95

of frontier Asia, 4

Poverty and poverty reduction

accomplishments in frontier economies, 6

in Bangladesh, $130 b$

financial sector development and, 142

future prospects for, 135

growth and, 120, 135

income inequality and, 122-123

international comparison, $114,117 t$

\section{C) International Monetary Fund. Not for Redistribution}


patterns and trends, 113-114, 115f,

$135,143 t$

pro-poor growth in frontier Asia,

117-120, $119 t$

in Vietnam, 133-134b, $133 f$

Price stability, 226

Public debt defaults, 40

financial sector vulnerability and, 44-45

fiscal crisis risk, 43

fiscal reforms to control, 40-43

inflation targeting and, 21

optimal composition, 40

risk of growth slowdown and, 98, 99

trends in emerging markets, 39-40

Public spending

growth and, 41-42

policies to foster inclusive growth,

123-126

See also Public debt

\section{Q}

Quality improvement, 66-69, 68f, 71, $72-74$

\section{$\mathbf{R}$}

Real estate sector, $189 b$

lending patterns, 166, 177-180

Regulations economic growth and, 91 reforms to promote financial inclusion, 129

See also Financial sector regulation

Remittances, $130 b$

Resource-dependent economies fiscal rules in, 36, 36b

governance challenges, 89-90

growth slowdowns in, 88-90

Revenue-to-GDP ratio, 39, $39 f$

\section{$S$}

Safety net programs, 125-126

in Bangladesh, 131-132b

Savings

demographic correlates with, 94

financial development and, 25, 48, 142, 165

Services sector, 88

Sex ratio, 94
Sierra Leone, $90 n$

Singapore, $196 t$

Small- and medium-sized firms, 7

Social insurance schemes, 125

South Africa, 28-29, 221

Spain, 37

Sri Lanka

bond markets, 221

Eurobonds, $5 b$

financial sector, 8, 168, 169, 172, $189 b, 191$

foreign bank entry in, $198 t$

State-owned banks, 7-8, 150-151, 151f, $161,165-166,167,167 f, 169 f$, $170-171 b$

Stock markets, 152, 153f, 163, 219

Structural reforms policies in support of, $70,71,78$ significance of, in growth of frontier economies, $\mathrm{v}$ as source of growth in frontier economies, 3

to sustain growth, 9, 41-42

vulnerability to growth slowdowns and, 82

T

Taxes

policies to foster inclusive growth, 123-125

policy reforms for sustainability, 40-41

public debt in emerging economies and, 39

revenue-to-GDP ratio, $39,39 f$

Telecommunications infrastructure, 93

Thailand

bond market, $5 b, 221$

financial sector, 7

foreign bank entry in, 187b, $194 t$

output quality, 69

Theil index, 60, 72, 96

Timor-Leste, 229

Trade structure

diversification, 59-60, 63-65, 64f, 65f, $66 f$

growth and, 3, 100-101

vulnerability to growth slowdowns and, $82,95-97,97 t, 98-99$ 
Transparency

central bank, 231

financial sector, 129

in fiscal risk analysis, 38

Transportation infrastructure, 93

Trilemma framework for analyzing monetary policies, 13-16, 14f, 227-228, $228 f$

Tropical climate, 99

U

Unemployment insurance, 125

United States, 5, 8, 9, 21

V

Value-added tax, 41

Vietnam

bond markets, 221

diversification experience in, 6, 70, $76-77,77 f$

Eurobonds, $5 b$

financial sector of, 7, 8, 158, 168, 170f,

$173,182,189 b, 191$ foreign bank entry in, $187 b, 199 t$

growth rate, $81,82 f$

income inequality in, $6,114,133-134 b$,

$133 f$

monetary policy, 227, 228f, 229,

230-231b, 231

output quality, 69

poverty reduction in, 114, 133-134b,

$133 f$

private credit in, 150

prospects, 1346

real estate boom, $189 b$

stock market, 152

See also Frontier economies

W

War, 99-100, $100 t$

World Bank, 186

$\mathbf{Z}$

Zambia, 89

Zimbabwe, 85-86, 102

\section{(C) International Monetary Fund. Not for Redistribution}


The publication of this book on Frontier and Developing Asia: the Next Generation of Emerging Markets is very timely. It closes an important information gap about the progress that many of the fast-growing low-income countries in Asia have made. Cambodia, for example, has experienced robust economic growth and rapid poverty reduction during the last two decades. These achievements have been supported by political, economic, and financial stability. The government has maintained a strong reform momentum to achieve sustainable and inclusive growth. In line with the Royal Government's policies, the National Bank of Cambodia (NBC) has successfully maintained macroeconomic and financial stability. The banking sector has been resilient, stable, and integrated within the regional and global markets. The NBC has promoted financial deepening and inclusion while ensuring stability. These improvements have contributed to enhancing confidence in the banking sector as well as the economy as a whole. The insights of this book will be extremely valuable for readers both within and outside of Asia.

Even as the emerging market economies deal with their growing pains we can see on the horizon the next set of developing countries poised for breakout. These frontier economies have already shown enormous potential for reform, structural change, and rapid growth, and within Asia alone they account for more than a third of a billion people. Their macroeconomic, financial, and institutional environments present both upside potential and significant risks. This path-breaking book helps us understand the complex development challenges these countries face. 